\title{
Planning Development: International Experts, Agricultural Policy, and The Modernization of Nigeria, 1945-1967
}

\author{
Bekeh Utietiang
}

Follow this and additional works at: https://researchrepository.wvu.edu/etd

\section{Recommended Citation}

Utietiang, Bekeh, "Planning Development: International Experts, Agricultural Policy, and The Modernization of Nigeria, 1945-1967" (2014). Graduate Theses, Dissertations, and Problem Reports. 6855.

https://researchrepository.wvu.edu/etd/6855

This Dissertation is protected by copyright and/or related rights. It has been brought to you by the The Research Repository @ WVU with permission from the rights-holder(s). You are free to use this Dissertation in any way that is permitted by the copyright and related rights legislation that applies to your use. For other uses you must obtain permission from the rights-holder(s) directly, unless additional rights are indicated by a Creative Commons license in the record and/ or on the work itself. This Dissertation has been accepted for inclusion in WVU Graduate Theses, Dissertations, and Problem Reports collection by an authorized administrator of The Research Repository @ WVU.

For more information, please contact researchrepository@mail.wvu.edu. 
Planning Development:

International Experts, Agricultural Policy, and

The Modernization of Nigeria, 1945-1967

\section{Bekeh Utietiang}

Dissertation submitted to the Eberly College of Arts and Sciences

At West Virginia University

in partial fulfillment of the requirements

for the degree of

Doctor of Philosophy

in

History

Robert Maxon, Ph.D., Chair

Joseph Hodge, Ph.D, Co-Chair

James Siekmeier, Ph.D.

Tamba M'bayo, Ph.D.

Cyanne E. Loyle, Ph.D.

Department of History

Morgantown, West Virginia

2014

Keywords: Nigeria Agriculture Colonial Modernization Race Development Britain Mokwa Stolper Mackie Cold War

Copyright 2014 Bekeh Utietiang 


\section{ABSTRACT \\ Planning Development: International Experts, Agricultural Policy and the Modernization of Nigeria, 1945-1967}

\section{Bekeh Utietiang}

The period after the Second World War was a significant moment in British colonialism in Nigeria. It was the height of the decolonization movements in many of Britain's colonial holdings and was the cradle of what David Low and J. M. Lonsdale call the "second colonial occupation." This occupation in which the British government carried out expansive development policies was an intentional attempt to wrestle with social unrest due to the neglect of the social welfare of the people during the Great Depression and in the period thereafter. Such a development vision was represented by the passage of the 1940 Colonial Development and Welfare Act. Unfortunately, the implementation of this act was interrupted by the war. After the war, this act was updated and passed in 1945. With a fund of $£ 120$ million earmarked for development in the colonies, this represented the single greatest financial investment by the British government in the colonies. Each of the colonies were asked to produce ten-year development plans. The plan that was produced by Nigeria depicts an important starting point in development planning and it reflected an agrarian bias. Several other plans have been produced since the 1945 plan. My study focuses on the 1945 plan and the 1962 plan which was the first post-independence national plan.

This study particularly looks at the process that resulted in the plan documents. This is important because it helps to reveal the factors that led to the success or failure of development plans. The planning process shows us that outcomes do not always reveal intentions and it is important not to use the outcomes to judge intentionality. This work argues that the failure of late colonial development in Nigeria was not as a result of bad intentions but because of the racial limitations inherent in the colonial state. Such limitations led to the exclusion of Africans in the development process and in the rejection of indigenously produced knowledge. A case study of the Niger Agricultural Project, Mokwa treated in the fourth chapter sheds light on the importance of local knowledge to the development process.

This study also reveals that persons and institutions matter in the development process. These reflect the human side of development. This dissertation shows how the feuds and conflicts between the technical departments and the political wing of the colonial state affected the 1945 colonial plan. The 1962 plan suffered because of conflicts between the main architect of the plan, Wolfgang Stolper, and the World Bank advisor to the prime minister, Narayan Prasad.

This work also shows that despite the rhetorical claims of modernization theorists such as Walt Rostow and his colleagues at CIS, in practice, modernization theorists continued colonial development policies. In Nigeria, the 1962 plan that was designed by US social scientists such as Stolper continued the agrarian bias that was emblematic of colonial development. The study concludes that both the colonial and early "postcolonial" plans were affected by five factors: development ideology, human resources, financial resources, International experts/indigenous knowledge, and corruption. 


\section{DEDICATION}

For my sister, Ethel and brother, Akpanke. 


\section{ACKNOWLEDGEMENT}

Without the support and help of many people, this work would not have been successfully completed. My sincere and heartfelt gratitude goes to my supervisors, Professors Robert Maxon and Joseph Hodge. They carefully read this work with interest, made several suggestions to help situate the work within a wider historiographical context. The exhaustive list of books and articles they introduced me to helped shape my views on development history.

My thanks also goes to the department of history and the Eberly School of Arts and Sciences for the conducive environment for graduate research and also for granting me the funding for this research. I am forever grateful to Professor Matthew Vester who suggested and encouraged me to apply to the history program at WVU. Other faculty members instrumental to my success are Professors Elizabeth Fones-Wolf, Krystal Frazier, James Siekmeier, Tamba Mbayo and Joshua Arthurs. Thank you for your help. My special gratitude goes to Martha May and Becky Warnke for always being there to help whenever I needed assistance from the department.

I couldn't have done this without the help of many of my friends. I remain grateful to them for their love, care and generosity. Thank you Tori Arthur for reading the first draft of this work and giving me feedback. My appreciation also goes to Dr. Anna Hughes, Fr. Alfred Obiudu, Dr. Debo Prest, Fr. Peter Amah, Angela Odin, Beshel Ikwen, and Fr. Livinus Uba. 
My family's generosity toward me has known no bounds. Thank you mum and dad for always standing by me and assuring me that I am capable of doing anything. My numerous brothers, sisters and relatives have been very understanding, even when weeks have gone by without me returning their phone calls. They also patiently listened to me discuss my research even when I bored them. So, thank you Dr. Ashiwel, Dr. Amaka Undie, Gerty, Unimke, Iye, Eli, Angy, Andor, Utietiang, UK, Adi and Bobby. My cousin, Dr. George Atelhe helped me track down some of the materials I needed. For this, I am grateful.

I have no doubts that I have missed several other people who have contributed to the success of this work. I want you to know that I treasure you in my mind. 


\section{TABLE OF CONTENTS}

Planning Development: International Experts, Agricultural Policy, and

The Modernization of Nigeria, 1945-1967

Abstract

Dedication

Acknowledgements

Abbreviations used

\section{Chapter One:}

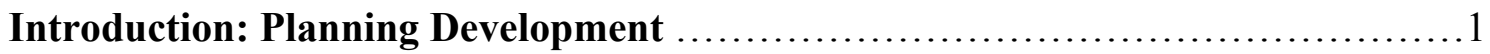

I. Introduction

II. Background

III. Summary Review of Scholarship

IV. Significance of Research

\section{Chapter Two:}

Planning Development in the Late Colonial Period

I. Introduction

II. Colonial Development Before 1929

III. The 1929 Colonial Development Act

IV. Planning Development, the 1940 Act

V. The 1945 Act and Development Planning in Nigeria

VI. African Labor and the Color Line

VII. Development and Insufficient Financial Resources

VIII. Bureaucratic Structures and the Exclusion of Africans

IX. Approval and Funding of the Plan: Caine Vs. Nigeria

X. African Agency

XI. The Rift Between Colonial Office and Nigeria

XII. Conclusion 


\section{Chapter Three:}

Planning Agricultural Development: The Mackiean Policy, 1936-1945............96

I. Introduction

II. The Nature of Colonial Rule in Nigeria

III. Captain James Richard Mackie

IV. Elite Mediation and Agricultural Development

V. Wartime Agricultural Planning

VI. Reorganizing the Departments

VII. The Agricultural Plan

VIII. Conclusion

\section{Chapter Four:}

Planning Agricultural Development: A Case Study of the Niger Agricultural Development Project, Mokwa ........................................... 165

I. Introduction

II. The CDC \& Economic Development after 1945

III. The Oilseed Mission to Nigeria

IV. Early Settlements and Cultivation at NAP

V. NAP as an Experiment

VI. Determining the Future of NAP

VII. Negotiating the End of NAP

VIII. NAP under the NRG

IX. Problems with NAP

X. Conclusion

\section{Chapter Five:}

Recreating the Nigerian State: The National Development Plan, 1962-1967.

I. Introduction

II. The Rise of Modernization Theory

III. The Advent of Modernization Theory in Nigeria

IV. Walt Rostow and the Modernization Gospel

V. The Independence Plans, 1955-1962

VI. Triangulating Development: Britain, the United States and Nigeria

VII. The Role of US Foundations

VIII. The Foundations, Arnold Rivkin and the African Project

IX. The Gatekeeper State

X. Wolfgang Stolper and the Nigerian National Development Plan

XI. Crafting the Nigerian Plan: The Stolper - Prasad Conflicts

XII. The Art of the Possible 
XIII. The Nigerian National Development Plan

XIV. Financing the Plan: American Aid

XV. The United States Special Economic Mission

XVI. Problems with the Plan

XVII. Conclusion

\section{Chapter Six:}

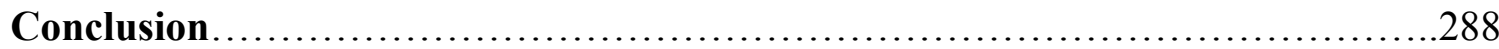

I. Development Ideology

II. Human Resources

III. Financial Resources

IV. International Experts/ Indigenous knowledge

V. Corruption

VI. Conclusion

Epilogue.

.303

Bibliography.

.307 


\section{ABBREVIATIONS USED}

\begin{tabular}{|c|c|}
\hline $\mathrm{CD} \& \mathrm{~W}$ & Colonial Development and Welfare \\
\hline CEAC & Colonial Economic Advisory Committee \\
\hline CIS & Center for International Studies \\
\hline $\mathrm{CO}$ & Colonial Office \\
\hline $\mathrm{CSG}$ & Chief Secretary to the Government \\
\hline DFP & Director of Food Production \\
\hline DLF & Development Loan Fund \\
\hline HMSO & Her Majesty Stationery Office \\
\hline EPU & Economic Planning Unit \\
\hline IBRD & International Bank for Reconstruction and Development \\
\hline IMF & International Monetary Fund \\
\hline JPC & Joint Planning Committee \\
\hline MED & Ministry of Economic Development \\
\hline MIT & Massachusetts Institute of Technology \\
\hline NAP & Niger Agricultural Project, Mokwa \\
\hline NCG & Nigerian Central Government \\
\hline $\mathrm{NCNC}$ & National Council of Nigeria and the Cameroons \\
\hline NEC & National Executive Council \\
\hline NNP & Nigerian National Plan \\
\hline NRG & Northern Regional Government \\
\hline OFC & Overseas Food Corporation \\
\hline PM & Prime Minister \\
\hline SAP & Structural Adjustment Program \\
\hline$S$ of $S$ & Secretary of State \\
\hline TUC & Trade Union Congress \\
\hline US & United States \\
\hline
\end{tabular}




\section{CHAPTER ONE \\ INTRODUCTION: PLANNING DEVELOPMENT}

\section{Introduction}

In the summer of 2010 I visited the old neighborhood where I grew up. It is located in a little town called Obudu in the southern-most part of Nigeria. Over the years, I had heard stories from family members about how it had changed since 1995 when I graduated high school and moved away from home to attend college. Around that time, my parents also moved to a small village seven miles away where everything was rural and the people were sustained economically through peasant agriculture. My old neighborhood was comprised mostly of educated middle class people. We had good schools - two public elementary schools just a few blocks from each other and two high schools, one for boys and the other for girls, also only a few blocks from one another. These were by all accounts excellent public schools, and I believe that I received a very good education. When one thinks of rural Africa in the 1970s and 1980s, one is tempted to think of the lack of public infrastructure. This was not the case in the neighborhood where I grew up. We had running water, constant electricity, landline phones, paved roads, televisions and radios, etc. When I returned from the United States in 2010 to my old neighborhood, I encountered a different reality. The schools had deteriorated and were now failing, running water was gone, electricity was at best erratic, and unplanned houses were squeezed into every available space. The whole place now looked like a slum. What I also discovered was that this problem was not unique to my old neighborhood; it was now a national problem. While I wept for my old neighborhood, I 
was left with the question: what happened? This question for me was my "historical turn." I had to try to find the answer to the developmental trajectory the nation had taken by looking at the history. How did we get here? This dissertation is an attempt to understand development by focusing on the planning process of the 1945 and 1962 plans. In Nigeria, since the 1940s, the state has been engaged in development planning. The state saw the planning process as important for development. It is my argument that in order to understand the policy interventions and programs that are intended to bring about "development", it is important to look at the planning process. Thus, my focus is on the often boring but revealing aspects of the planning process. Looking at this planning process is important because it helps to reveal the ideology that drove the architects of these plans and how these plans reflect the interests of the planners. The planning process also reveals the human side to development planning. Thus, I pay close attention to individuals that were part of the planning process and their relationships.

Nigeria has a history of development planning. Between 1945 and 1981, the country launched six specific development plans. My study focuses on only two of the development plans: the 1945 ten-year plan and the 1962 six-year plan. I picked these two plans because they help to shed light on planning in the late colonial period and in the early "postcolonial" period. The architects for the 1945 plan were the colonial administration and they drew the plan for a ten-year period. On the other hand, the new independent Nigerian government prepared the 1962 plan. Though Britain remained a factor in the drafting and implementation of this plan, US social scientists and

\footnotetext{
${ }^{1}$ I use the term "historical turn" to describe the point in which I decided to look back and find out how "development" came about in the first place and its roots in the specific case of Nigeria.
} 
foundations took on a more leadership role. Studying these two plans allows us to see the continuities and discontinuities between development in the late colonial and early "postcolonial" periods and also enables us to see the ideas that drove development.

Developmental planning in the late colonial period by the British was influenced by a set of ideas that were different from the American led modernization in "postcolonial" Nigeria. My study uncovers some of these ideas. It is important to note however that, in practice, American led development in Nigeria adopted and continued most of the development policies of the British. While the 1945 plan focused on the improvement of the social conditions of the colonial people and the development of colonial economic resources for the benefit of the British government and the Nigerian people; the 1962 plan, driven by American social scientists and the World Bank, placed less emphasis on public investments but more emphasis on short term economic growth. Both development plans focused on several sectors of the Nigerian society: education, medicine, markets, and agriculture. It is almost impossible to study all of these within the scope of this work. I will narrow my focus to the planning process in general and to agricultural policy. It was only in the late 1950 s that petroleum exploration started in Nigeria and it took over a decade for the Nigerian economy to become mainly dependent on petroleum revenues. Before this time, agriculture was the primary revenue generator for the economy. The plans were to a large extent dependent on revenues from agriculture for their implementation.

In the second chapter of this dissertation, I will be looking at the planning process that led to the 1945 plan. I will situate this chapter within the history of colonial development beginning with the passage of the 1929 Colonial Development Act through 
the passage of the 1945 Colonial Development and Welfare Act. I will pay close attention to the discussions and negotiations between the Nigerian colonial state and the $\mathrm{CO}$ as they crafted the ten-year Nigerian plan. Having looked at the general planning process, in the next chapter, I will focus on the agricultural plan and how this plan was rooted in the agricultural policy that had been operative in Nigeria beginning from the time of $\mathrm{O}$. $\mathrm{T}$. Faulkner, the director of agriculture in the 1920s. I will credit James Mackie as the architect of the Nigerian agriculture plan. The development of this plan was besieged by problems as Mackie and his staff were constantly in conflict with the political officials of the colonial state. My argument is that these conflicts, which reflect deeply the human element in the planning, had significant impact on the agricultural plan and its implementation in Nigeria. I devote the fourth chapter to analyzing a specific agricultural scheme, the Niger Agricultural Project, Mokwa. The reason I will give special attention to this scheme is because it was the first capital-intensive mechanized agricultural project carried out in Nigeria by the British. This project, located in a town called Mokwa in Northern Nigeria, failed within five years after it was established. In the end, the attempt to use highly mechanized agricultural equipment to produce high yields and to improve the living standards of the rural people was unsuccessful. The last chapter of this dissertation focuses on the transition from colonial-led development to American-led modernization theory. In this chapter, I will look at how American social scientists and foundations helped in the designing of the first Nigerian national plan and I will analyze the problems with that plan. I will argue that development in the early "postcolonial" period did not mark a break from development in the late colonial period. As a result of the changing social and political landscape in the world (the cold war and 
decolonization), there was a change in the rhetoric but not in the practice. Thus, American social scientists and foundations had grand visions and proclamations to recreate the Nigerian state into a modern one, in the likeness of America. I argue that in practice, their prescriptions for modernization were no different from the development policies followed by the British in the late colonial period.

My research looks at development as a historical process; in other words, history is used as a methodology for studying and understanding development. The word 'development' means several things to several people and so it is important to define what I mean by development and agricultural development in particular. Writing on development, Zymunt Bauman notes that, "The modern mind was born together with the idea that the world can be changed. Modernity is about rejecting the world as it has been thus far and the resolution to change it. The modern way of being consists in compulsive, obsessive change: in the refutation of what 'merely is' in the name of what could, and by the same token ought, to be put in its place." "2 He sees development as rooted in the Enlightenment period. Michael Cowen and Robert Shenton argue that development arose in reaction to the Enlightenment. They argue that there is an immanent process of development which is both constructive and destructive. An example is the expansion of capitalist market forces. They however make a distinction between this process and the practice of development which arose as an intentional or conscious attempt by the state to intervene in those market forces in order to deal with the crises that inevitably occur, such as the Great Depression or to put it more precisely, the problem of surplus labor due to

2 Zygmunt Bauman, Wasted Lives: Modernity and its Outcasts (Oxford: Oxford University Press, 2003), 23. 
unemployment and underemployment. The state becomes the trustee of development in order to respond to a perceived lack of the same. Development for Cowen and Shenton is different from natural progress. They write, "development was the means by which progress might be ordered but it was not the idea of progress itself....the idea of development as an immanent process did not necessarily rest, as did the idea of progress, upon a conviction that the future would be an improvement upon the past." ${ }^{3}$ In the context of development planning and state directed schemes for improvement, Cowen and Shenton's definition seems to be more useful, and therefore, this is the definition I will use throughout this dissertation. Such schemes were intentional attempts by both the colonial and "post-colonial" state to bring about both social and economic progress.

This study begins in 1945, which marks the launch of Nigeria's first development plan. In 1940, the British parliament passed the Colonial Development and Welfare Act, ${ }^{4}$ which marked a significant shift in Britain's policy toward the development of the colonies. ${ }^{5}$ The study ends in 1967 because it was the year that the first Nigerian "National" development plan was interrupted as a result of the civil war. ${ }^{6}$

\section{Background}

Nigeria, in pre-colonial, colonial and "post-colonial" times has undergone several phases of development. The exploration of the interior of Nigeria was only possible because of technological advances. Prior to colonial rule, Nigeria was linked to the world market through slavery and the cultivation and trade of agricultural products. After the end of slavery, agricultural products became the major export from Nigeria. The three

${ }^{3}$ Michael Cowen and Robert Shenton, Doctrines of Development (New York: Routledge, 1996), 7.

${ }^{4}$ Hereafter, CD\&W act.

${ }^{5}$ More on this shift in the literature review and also in the second chapter of the dissertation.

${ }^{6}$ The word "national" is in quotes because my dissertation questions if this was truly a national plan. 
main exports from Nigeria were palm oil, groundnuts and cocoa. In 1806, West Africa (which includes present-day Nigeria) provided 150 tons of palm oil annually to Liverpool. By 1839, Britain was receiving 13,000 tons of palm oil annually, and the main supply was from the Niger Delta Protectorate. Palm oil supply reached a peak of about 30,000 tons in $1855 .^{7}$ Palm oil imports continued to be important even after 1885 . Michael Crowder wrote that, "[i]n 1908, exports were valued at £3,094,175 as compared with $£ 4,320,000$ in 1910 , whilst the figures for imports were respectively $£ 3,076,309$ and $£ 5,122,000$. Exports consisted mainly of palm products." ${ }^{\prime 8}$ Palm trees originally grew wild in Nigeria and, for many years, supplied Europeans with oil. In the middle of the 1920s, there was greater competition coming from Eastern Asian and Belgian Congo palm products. In response, the British government took steps to secure and improve production from Nigeria and other West African countries. ${ }^{9}$ To enable an increase in production, the United Africa Company donated 250 hand press machines that were to be used by farmers. ${ }^{10}$

Cocoa was also another major export from Nigeria during the colonial period. It was introduced into Nigeria at the end of the nineteenth century. It was the major source of income for many farmers in Southern Nigeria. During the Great Depression, the price of cocoa fell drastically and many farmers abandoned cocoa farming. In addition, during this time of economic depression, two diseases infested cocoa: the swollen shoot and the

\footnotetext{
${ }^{7}$ Philip Ehrensaft, “The Political Economy of Informal Empire in Pre-Colonial Nigeria, 1807-1884," Canadian Journal of African studies 6, 3 (1972): 456

8 Michael Crowder, A Short History of Nigeria (New York: Frederick A. Praeger, 1966), 233.

${ }^{9}$ Great Britain. Colonial Office, Committee on Improved and Increased Production of Palm Oil and Palm Kernels in West Africa. (London: HM Stationery Office, 1925), 10.

${ }^{10}$ R. Olufemi Ekundare, An Economic History of Nigeria 1860 - 1960 (New York: Africana Publishing Company, 1973), 166.
} 
black pod. In 1944, the British West African governments opened a research institute called the West African Cocoa Research Institute at New Tafo, Ghana to deal with cocoa diseases. ${ }^{11}$ A substation of this institute was established in Ibadan, Nigeria in 1950. Given that cocoa was a major export from Nigeria, it was important to establish a research center to study diseases that affected production and to mitigate against them. This research institute was used for investigations and trials toward improving cocoa production.

Though cotton had been grown in Nigeria for centuries, commercial cotton growing only began in the first decade of the twentieth century. This was encouraged by the British Cotton Growing Association and also some trading firms such as the Messrs. Elder Dempster \& Co. This company brought tons of seeds they bought from New Orleans to Nigeria to be distributed to farmers. ${ }^{12}$ Groundnuts were also cultivated in Northern part of Nigeria. Though it was cultivated in the pre-colonial times, it was only after 1900 that it became important as a cash crop. ${ }^{13}$ The Agricultural Department distributed groundnut seeds free to farmers. ${ }^{14}$

The expansion of cash crops production in Nigeria by peasant ${ }^{15}$ farmers was important to the British colonial administration between 1900 and 1940 because they saw

\footnotetext{
11 Ibid., 168.

12 Bade Onimode, Imperialism and Underdevelopment in Nigeria: The Dialectics of Mass Poverty (London: Zed Press, 1982), 46.

13 Ibid., 44.

${ }^{14}$ Ekundare, An Economic History of Nigeria, 168.

15 By peasants I mean smallholder farmers who cultivated for their own consumption and for the markets. Their production was always small scale and relied mainly on family or communal labor. A small number of peasants retained paid labor but this was never in the scale of industrial agriculture.
} 
trade as the instrument necessary for the implementation of its "Dual Mandate." "Its policies were not geared toward the expansion of plantation agriculture. The administration discouraged the establishment of foreign-owned plantations in Nigeria. ${ }^{17}$ Anne Phillips in her work, The Enigma of Colonialism, states that, "If colonialism was a project of capitalist expansion, then in Africa it significantly failed in its task." ${ }^{18}$ She argues that the contradictions of colonial power are rooted in the makeshift character of British rule. The colonial state was constrained by the local conditions. Initially, the British wanted to move towards a capitalist market in land and labor, but because of the resistance and turmoil this stirred up, they retreated. The political weakness of the colonial state meant that it lacked the power to directly coerce labor and it had to form alliances with local chiefs "as the only reliable guarantors of labour, which in turn dictated the terms on which colonialism operated. The recurrent problems of land and labour revolved around this alliance with chiefs. Free access to land precluded the formation of a landless proletariat, and was ensured by relations of communal land tenure which installed the chiefs as agents of political order." 19 This, she argues, curtailed the power of the colonial state to alienate land for large industrial agricultural plantations. These local conditions forced the British to take the path of peasant agriculture development. ${ }^{20}$ The stability and security of the colonial state depended on the cooperation of local rulers and the authority of these rulers rested in the control of land

\footnotetext{
${ }^{16}$ The dual mandate, a phrase coined by Lord Lugard, one of British colonial governors in Africa, captures British imperialism in Africa. It is an imperial principle that the resources of the colony should be exploited for the benefits of metropole and colony.

17 Ekundare, An Economic History of Nigeria, 158.

18 Anne Phillips, The Enigma of Colonialism: British Policy in West Africa (Bloomington, In: Indiana University Press, 1989), 3.

19 Ibid., 11.

${ }^{20}$ Ibid., 11-12.
} 
and labor. This was because of the land tenure system in West Africa. Land was communally owned and adult males were guaranteed access to the land for farming. In the same way the local chiefs had power over labor, so did they over land. By allowing big industrial agricultural corporations to expand, the British would have undermined the indigenous authority on which the colonial state itself ultimately rested. ${ }^{21}$ The expansion of cash crops and trade in West Africa up to the early $20^{\text {th }}$ century was largely a spontaneous process of the expansion of capitalist market forces. Thus, farmers in western Nigeria and southern Ghana started the planting of cocoa because they recognized the market prosperity that this brought. The colonial state's decision to consciously block plantation agriculture and large-scale farming in lieu of peasant farming under the tutelage of local rulers, who would continue to control land and labor, was an intentional practice of development. The "Dual Mandate" and "indirect rule" in West Africa is what Cowen and Shenton called a "doctrine of development."

Between 1940 and 1960, there was a significant change in British policy in Nigeria that affected agricultural production. The changes that were initiated in the $1940 \mathrm{~s}$ stemmed from results of the Great Depression. Prior to the economic depression of 1929 , the colonial government in Northern Nigeria, for example, was able to balance its budget through revenues derived from agricultural products and tin mining. These two industries were adversely affected by the depression. European goods were no longer imported and

\footnotetext{
21 The colonial state was not as powerful as it is sometimes purported to be. Fred Cooper argues that, "the much celebrated policy of 'indirect rule' in British Africa ... represented an attempt to make retreat sound like policy." See Frederick Cooper, Decolonization and African Society: The Labor Question in French and British Africa (Cambridge: Cambridge University Press, 1996), 11. On how African labor undermined the authority of chiefs and white administrators in Kenya, see Bruce Berman, Control \& Crisis in Colonial Kenya: The Dialectic of Domination (Athens: Ohio University Press, 1999), 61.
} 
the agricultural products were no longer exported, leading to falling crop prices. In his book, Colonial Meltdown: Northern Nigeria in the Great Depression, Moses Ochonu argues that the colonial state had to engage in severe economic adjustment policies to keep the budgets balanced. The colonial state, he argues, did not use a Keynesian economic model $^{22}$ as a solution but engaged in strict austerity measures such as cutting down on public works projects, increasing taxation, enforcing high crop production, making pay cuts, retrenching workers and introducing protectionist policies. ${ }^{23}$

In his article, "The Dynamics of Long-Term Agricultural Development in Nigeria" Carl Eicher argues that three main policy matters were associated with these changes. ${ }^{24}$ The first was the establishment of government marketing boards in 1939 and 1940. During World War II Britain took steps to prevent the export of Nigerian goods to the Germans and their allies and to only allow imports to Nigeria from Britain and its allies. This made a number of European markets no longer accessible to Nigeria. The US market was also no longer easily accessible to the Nigerian exports due to insecurity in the seas and the limits on shipping space. Britain was afraid of the cocoa industry collapsing, which might thereby lead to political and social chaos in Nigeria. Britain decided to buy the entire cocoa crop and was willing to incur losses if necessary. This

\footnotetext{
22 John Maynard Keynes argued during the Great Depression that the solution to the problem of the depression was the stimulation of the economy and this could be done through cutting the interest rates and governments investing in infrastructure. Ochonu's argument is that, rather than the colonial state investing in the infrastructure, they cut public investment.

${ }^{23}$ Moses E. Ochonu, Colonial Meltdown: Northern Nigeria in the Great Depression (Athens: Ohio University Press, 2009), 28-29.

${ }^{24}$ Carl K. Eicher, "The Dynamics of Long-Term Agricultural Development in Nigeria," Journal of Farm Economics 49, 5 (1967): 1161.
} 
was the genesis of government marketing boards. ${ }^{25}$ At their inception, the marketing boards had the task of issuing licenses to private firms to purchase locally produced goods that they in turn sold to the colonial government. Though originally intended to stabilize prices, they had an unintended outcome in which they evolved into a system of indirectly taxing agriculture. As Falola argues, "The underpayment to the producers enabled the firms to make profits and the government to raise money to finance the war without raising taxes." 26 The contradiction between intentions and outcomes is one that plagued development throughout the period of colonial rule. This contradiction is important to my study because the outcomes do not always explain the intentions.

The second policy was the establishment in 1940 of a research system for studying export crops. Eicher argued that American scholarly research ignored these centers because of the assumption that they were non-existent before US foundations helped launch the International Maize and Wheat Improvement Center in Mexico and the International Rice Institute in the Philippines. ${ }^{27}$ Before the Green Revolution of the 1970s, many European nations had successfully undertaken systematic attempts to devise technologies that will lead to improved varieties for the peasant farmers. Jonathan Harwood states that, "around 1900 several Central European states established plantbreeding stations whose express purpose was to make high-yielding plant varieties as well as the basic techniques of plant breeding available to the small farmers who

\footnotetext{
25 Toyin Falola, Economic Reforms and Modernization in Nigeria, 1945-1965 (Kent: The Kent State University Press, 2004), 79.

26 Ibid., 21.

${ }^{27}$ Eicher, "The Dynamics of Long-Term Agricultural Development in Nigeria," 1162.
} 
predominated in those regions." 28 In British colonies, there were agricultural research centers prior to 1940. After 1940, these were substantially expanded with assistance from the CD\&W Acts of 1940 and $1945 .^{29}$ Examples of such centers were the Cocoa Research Institute in Ghana, which was founded in 1938, and the Oil Palm Research Station in Nigeria founded in 1939. By 1951, these research institutes were expanded and new ones were established around West Africa. There were a total of ten.

Finally, the British administration instituted a third policy in response to the depression; the introduction of deliberate government development planning. Each British colony was asked to produce a ten-year development plan. The plans were to focus not only on the development of the economic resources of the colony but also to improve the social conditions of the colonial people. The 1940 and 1945 CD\&W acts stimulated the systematic attempt to develop agricultural production, not just in Nigeria but in colonies throughout the British empire. The first development plan for Nigeria was put out in 1945. Though originally prepared during the war years to last for fifteen years, in light of the 1945 act, it was reduced to ten years. The plan was to last until 1955 after which the progress of development would be reviewed and a new development plan would be set in motion. By 1950, it became obvious that planning for ten years was too long and the ten-year plan was broken into five-year plans. The 1945 plan placed emphasis on agriculture as the mainstay of the Nigeria's economy. The colonial state had a great impact on Nigerian agriculture. However, the initiative to cultivate peanuts, oil

\footnotetext{
28 Jonathan Harwood, Europe's Green Revolution and its Successors: The Rise and Fall of PeasantFriendly Plant Breeding (Abingdon: Routledge, 2012), 2.

${ }^{29}$ In the next chapter, I will explain these Acts and their significance.
} 
palms and cocoa came from rural Nigerians, who saw economic advantages producing these.

By the late 1940s, there was a shift in Nigerian agriculture. The colonial state took on a direct intervention in agricultural production which before this time had remained in the hands of peasants but was indirectly supported through research on new crops and improved varieties. Instrumental to this intervention in Nigeria was the presence of the Colonial Development Corporation (CDC), which sponsored some development schemes in partnership with the colonial government. The CDC and the Overseas Food Corporation (OFC) were founded at the height of the sterling crisis to develop the economic resources of the colonies. With these corporations, the state was now prepared to take production into its own hands, using the latest technology and large subvention of funds. In Nigeria, unlike the agricultural policy of Faulkner and Mackie that insisted on research and trials before significant changes, the colonial state was now directly intervening in agriculture without this process. This was the reason for NAP and other similar projects throughout the British colonies. In Africa, most of these schemes failed or did not live up to the expectations of the state planners. The failure of these schemes, and development in general, in this period marked the end of the so-called "second colonial occupation" 30 and the transition of power from the colonial state to indigenous rule. As this process was unfolding, the US assumed a greater presence in the former colonial states and most especially in India and Nigeria.

\footnotetext{
30 This was a concept coined by Low and Lonsdale to describe the expansive development policies introduced by the British after the Second World War. Massive projects were carried out in the field of agriculture with the intention holding onto the colonies while at the same time boosting the economy of Britain. D.A. Low and J.M. Lonsdale, "Introduction: Towards the New Order, 1945-63, " in History of East Africa vol. 3, (Oxford: Clarendon Press, 1976).
} 
In the period shortly before and after the independence of Nigeria, the US took on a special development role. Though British personnel continued to staff Nigeria's government and Britain remained the biggest financial supporter of Nigeria, America more and more had a greater voice in the affairs of Nigeria. American social scientists and foundations that had the goal of modernizing Nigeria and stemming the tide of communism midwifed this role. This was not a situation that was unique to Nigeria, but was part of a global transfer of power from the British to the United States. After the Second World War and the Suez Crisis of 1956-57, Britain became incapable of policing the world. America, in the middle of the Cold War, saw the need to stem the spread of communism. Some sub-Saharan African nationalists became advocates of a socialist economy and America saw Nigeria as a country that could be used as a model of capitalism for other sub-Saharan Africa countries. In terms of population, Nigeria was the biggest African nation and its transition to democracy was relatively peaceful. Larry Grubbs writes, "Americans led a worldwide chorus of optimists in the early 1960s that imagined Nigeria as an exemplary nation in the making. A federal system of government, responsible, 'moderate' nationalist political leaders, an expanding free-market economy, and abundant natural and human resources beckoned observers looking for a model state in Africa." ${ }^{31}$ Encouraged by Arnold Rivkin, the founder of the African Project at the Center for International Studies (CIS) ${ }^{32}$ the American government and some foundations, such as the Ford Foundation, became involved in the modernization of Nigeria. A new

\footnotetext{
31 Larry Grubbs, “Bringing 'The Gospel of Modernization' to Nigeria: American Nation Builders and Development Planning in the 1960s," Peace \& Change 31, 3 (July 2006): 282.

32 The Center for International Studies was founded in 1951 by Max Millikan at the Massachusetts Institute of Technology. The official name of the center was originally CENIS, but today it is CIS. Throughout this work, I will use CIS to refer to it. In the fifth chapter, I shall discuss the significance of CIS for modernization theory.
} 
development plan was crafted for Nigeria and this plan was to last from 1962 to 1968. Since this plan came about after the independence of Nigeria, it is officially called the First National Development Plan. This plan was created and implemented with the help of American social scientists backed by the African Economic and Political Development Project at the CIS. ${ }^{33}$ Wolfgang Stolper of CIS played a primary role in the drafting of this plan. He was dispatched to Nigeria by the Ford Foundation to head the Economic Planning Unit (EPU) within the Nigerian Federal Ministry of Economic Development. Stolper was in Nigeria for about eighteen months. After leaving Nigeria, he wrote a book on his experience designing the Nigerian plan, entitled Planning without Facts. Before the full implementation of the Nigerian plan could occur, military coups and countercoups erupted that led to many Nigerian leaders being killed, further degenerating the country into a civil war. The war lasted from 1967 to 1970, causing the interruption of the full implementation of this plan. The fifth chapter of this dissertation will look at the work of CIS in crafting this development plan.

\section{Summary Review of Scholarship}

From the nationalist perspective, Nigerian development plans have received some attention. This assessment has often focused on the specifics of the plans and their implementation. The successes or failures of these plans are judged against the stated economic goals. The literature on both the 1945 and 1962 plans has measured these plans based on their economic growth and the impact on the people. Such an approach is not completely out of place given that these scholars have mostly been economists and their tendency is to see development in terms of immanent process that can be measured. One

\footnotetext{
33 This African project was founded by Arnold Rivkin.
} 
of such economists was Ojetuni Aboyade, a professor at the University of Ibadan. In his Foundations of an African Economy: A Study of Investment and Growth in Nigeria, he looked at the history of the Nigerian economy measuring its growth and identifying the economic problems that were responsible for Nigeria's underdevelopment. His book paid close attention to Nigerian development plans and he offered a new direction to development planning. He argued that the ten-year development plan instituted by the British in the late colonial period cannot be properly called a development plan. He noted that this plan was "more a catalogue of little interrelated proposals with ill-defined goals and no coherent statement of policy." 34 This argument is one that has been repeated by some other national economists. They argue that the 1945 plan did not have any systematic model or guiding principle. What became a plan was an amalgam of different projects or schemes. ${ }^{35}$ Toyin Falola in his book, Development Planning and Decolonization in Nigeria, is critical of scholars who have dismissed the 1945 plan. He argues that the 1945 plan shaped future Nigerian development plans as they reflect both the colonial economic policy "and the country's intellectual history.",36

The 1962 plan has received a more favorable acceptance by the above mentioned Nigerian economists albeit not without their criticisms. Their acceptance of the document as a development plan is based on the fact that economists designed it and grounded it in targeted economic growth projections. While this strong economic basis for the plan

\footnotetext{
${ }^{34}$ Ojetunji Aboyade, Foundations of an African Economy: A Study of Investment and Growth in Nigeria (New York: Frederick A. Praeger, 1966), 150.

35 Pius Okigbo, National Development Planning in Nigeria, 1900-1992 (London: James Currey, 1989), 154. Edward Ayo also made the argument that this plan is hardly a development plan in any serious sense. Like Aboyade and Okigbo, he argued that it was just a list of projects. Edward Jide Ayo, Development Planning in Nigeria (Ibadan: University Press Limited, 1988), 2.

36 Toyin Falola, Development Planning and Decolonization in Nigeria (Gainesville, FL: University of Florida Press, 1996), xxi.
} 
earned it acceptance as a development plan, Aboyade found the plan too pragmatic and technical and believed that it ignored the wider social issues in planning. ${ }^{37}$ In his perspective, development plans need to be tools of social change of which the question of income redistribution must be a fundamental part of the production system. ${ }^{38}$ Both Okigbo and Ayo argue that the problem with the 1962 plan was the lack of data and indiscipline in its implementation. Okigbo, who was a contemporary of Aboyade and had the position of serving as the head of the Eastern Region Economic Planning Unit when the plan was being drafted, argued that the plans were at best based on educated guess work because the data collection was poor and the plans did not rest on solid studies. ${ }^{39}$

The argument that the problem of development in Nigeria is rooted in the indiscipline and internal problems is one that has been challenged by Jeremiah Dibua, a Nigerian historian in the United States. He argues that the modernization paradigm plays a central role in the creation and perpetuation of the crisis of development in Africa. He does not discount the internal problems in Africa, such as corruption, ineptitude, authoritarianism, and the patrimonial nature of some states. But these, for him, are not the cause of Nigeria's crisis. The crisis is rooted in the attempt to export and plant western modernization models or paradigms in Nigeria where the socio-cultural realities are different than in the West. For him, the reason for the failure of modernization inspired programs in Africa is the paradigm itself and he shifts his analysis from the internal

\footnotetext{
37 Aboyade, Foundations of an African Economy, 160.

38 Ibid., 246-247.

39 Okigbo, National Development Planning, 149-150. See also Ayo, Development Planning in Nigeria, 184.
} 
problems to the idea of modernization itself. ${ }^{40}$ Dibua is critical of the 1962 development plan and the plans thereafter. He argues that development planning in Nigeria, as evidenced in the 1962 plan and beyond, was a product of "Eurocentric diffusionism." He writes that "Eurocentric diffusionism through modernization, which only attributes history to European societies while denying history or any form of meaningful autonomous development to African societies, fostered ethnocentrism and false universalism that negatively affected development planning in Nigeria."41 Rather than minimalize the role of the state in development planning, he argues in the book for state intervention in development.

While these works provide helpful socio-economic and political analysis of the development plans, they did not see these plans as a historical process. My study challenges the argument that the 1945 plan was not a development plan. The reason these authors dismiss the 1945 plan is because the plan did not have systematic economic projections and statistically measured means of achieving those projections. By focusing my study on the planning process and not just the plans, what becomes revealing is the intentional attempt by the state to direct development. The process of planning in the 1945 plan was more involved than a simple amalgamation of projects into a document as these scholars seem to believe. My work will show a painstaking process of negotiations that had the intended outcome of ordering Nigeria's progress not only economically but also socially. These scholars have also rightly identified some of the problems that plagued the development plans. However, by focusing on the planning process we gain

40 Jeremiah I. Dibua, Modernization and the Crisis of Development in Africa: The Nigerian Experience (Brookfield, VT: Ashgate, 2006), 19, 27.

${ }^{41}$ Jeremiah I. Dibua, Development and Diffusionism: Looking beyond Neopatrimonialism in Nigeria, 1962-1985 (Palgrave Macmillan, 2013), xii. 
more insights into these problems and become aware of some deeply inherent problems that the official plan documents do not reveal. For example, it is by studying this planning process that it becomes evident how the human element mixed with regional politics transformed the 1962 development plan at the last minute from a five-year plan to a six-year plan.

Though the literature on development history in Nigeria is sparse, there is a growing body of works on the history of development and in particular development in sub-Saharan Africa. My work speaks to some of the themes and issues in this expanding literature. Some scholars who have looked at development in the postwar period have argued that the practice and theory of development arose when President Harry Truman, in his 20 January, 1949 inaugural speech, announced his "fair deal" and set forth a doctrine that offered a new way to the understanding of world affairs. Truman's agenda was in response to the postwar discovery of massive world poverty. Arturo Escobar argues in his book Encountering Development that the dream that Truman set forth was not one that was solely created by the United States but it was a "result of the specific historical juncture at the end of the Second World War." ${ }^{, 42}$ Development was an invention of the west in the period after the Second World War and it was used as an instrument for the exportation of western moral and cultural superiority to the Third World and the imposition of western knowledge and ideas upon these people whom the west treated as "a child in need of adult guidance.",

\footnotetext{
${ }^{42}$ Arturo Escobar, Encountering Development: The Making and Unmaking of the Third World (Princeton: Princeton University Press, 1995), 4. See also Gilbert Rist, The History of Development: From Western Origins to Global Faith (London: Zed Books, 1997).

${ }^{43}$ Escobar, Encountering Development, 30.
} 
This view that development was invented in the post-war period has been challenged by some recent historiography in colonial development. This new historiography advances the position that development was not a construction of the postwar period but was already present on the eve of the war as an intentional attempt by the colonial governments to respond to the economic depression of the late 1920s and early 1930s. As Joseph Hodge argues in his book Triumph of the Expert, severe economic depression and the resultant unrest in the colonies "marked a critical turning point in the colonial encounter, setting off a far-reaching process of official rethinking and reform designed to forestall popular discontent and give a new lease on life and legitimacy to the imperial project." 44 The development discourse of the period after the war in response to world poverty was not a novel project as the colonies had for several decades made attempts to harness the resources of the colonies to respond to the poverty of the colonial period. In the late 1890s, Britain believed in the promise that the African colonies held. This potential was based on the power emanating from the use of science and technology. Joseph Chamberlain, who was colonial secretary in 1895 , believed that through science and technology, the state could play a powerful role in the imperial project. Chamberlain believed that the success of Britain's trade and industry depended on the opening up of the colonies and he thus linked colonial development to "social reform at home in an

\footnotetext{
${ }^{44}$ Joseph Hodge, Triumph of the Expert: Agrarian Doctrines of Development and the Legacies of British Colonialism (Athens: Ohio University Press, 2007), 2.
} 
effort to unite capital and labor in the cause of empire." ${ }^{45}$ His agenda that was focused on Britain's interest also could potentially benefit colonial progress. ${ }^{46}$

Chamberlain's vision of linking the colonies and the metropole economically was strengthened as a result of the experience during the First World War. It was important that the supply of food and raw materials be secured and developing the colonies was seen as a viable solution. ${ }^{47}$ What happened in Africa also after this war was that Britain and France received the former German colonies and they now took on a role of that of trustee over these colonies. As Hodge argues, the new emphasis on trusteeship created "new demands for state direction and control in such areas as health, sanitary administration, education reform, and rural welfare."48 This shift gave the scientific community a new role in empire. Though European scientific societies had been exploring Africa since the 1870s, but by the 1920s and 1930s, Helen Tilley argues, Africa became a laboratory in which all kinds of scientific enquiries ranging from medicine, biology, anthropology or even racial science was tested. Colonialism and science had entered a realm in which "scientific research was coupled more decisively to imperial

\footnotetext{
${ }^{45}$ Ibid., 44.

${ }^{46}$ Michael Havinden \& David Meredith, Colonialism and Development: Britain and its Tropical Colonies, 1850-1960 (London: Routledge, 1993), 87.

47 Ibid., 132-133.

${ }^{48}$ Hodge, Triumph of the Expert, 118.
} 
policy making and colonial development." ${ }^{49}$ The science exported to Africa was not just European science but it was shaped by the colonial context. ${ }^{50}$

Several regions of Africa in the period before and after the Second World War would serve as experimental laboratories for colonial policies. For example, in the Sukumaland region of Tanganyika, the British carried out intensive developmental interventions in order to curb environmental problems. There were efforts by the colonial government to conserve land from degradation. ${ }^{51}$ This was also the argument for British intervention in the Baringo district of Kenya in the 1930s. As David Anderson shows in his book, Eroding the Commons, the land degradation this region faced as a result of overstocking of goats caused the British by the mid-1940s to intervene in development through rangeland reconditioning schemes by introducing reseeding, rotational grazing and animal destocking. The impact of these schemes was negligible. Baringo was "both a symbol of the essential need for colonial intervention in African land husbandry and a testing ground for colonial ideas on how reform should be implemented." 52

These experimental attempts on development in Africa were not always successful. They sometimes met with local opposition. Part of the reason was that these development efforts were objects of social engineering. The control of resources was being shifted from the people to state institutions. Planning itself was used as a means of

\footnotetext{
${ }^{49}$ Helen Tilley, Africa as a Living Laboratory: Empire, Development, and the Problem of Scientific Knowledge, 1870-1950 (Chicago: University of Chicago Press, 2011), 3. See also, Andrew Bowman, "Ecology to Technocracy: Scientists, Surveys and Power in the Agricultural Development of LateColonial Zambia," Journal of Southern African Studies 37, 1 (2011).

50 Christophe Bonneuil, "Development as Experiment: Science and State Building in Late Colonial and Postcolonial Africa, 1930-1970," Osiris 15 (2000): 260.

51 Rohland Schuknecht, British Colonial Development Policy after the Second World War: The Case of Sukumaland, Tanganyika (Berlin: Lit Verlag, 2010), 9.

52 David Anderson, Eroding the Commons: The Politics of Ecology in Baringo, Kenya 1890-1963

(Oxford: James Currey, 2002), 2.
} 
constructing the state and bringing the people under state control. ${ }^{53}$ Alden Young makes a compelling case for this goal of planning development in his 2013 doctoral dissertation. The creation of a centralized development process in the late colonial Sudan led to finance officials asserting their authority over economic development throughout AngloEgyptian Sudan. He writes, "Finance officials expanded their supervisory powers by mandating that all economic projects begun after 1946 needed to demonstrate that they would contribute to the economic development of the entire territory. In the process, finance officials were able to impose the idea that the Anglo-Egyptian Sudan was the principal unit of economic management." ${ }^{54}$ In several instances, the people resisted the attempt by the state to reorder their societies. In the case of Sukumaland, the opposition from the people paved the way for the nationalist party, the Tanganyika African National Union. In Baringo, the Tugen people resisted British policies and Daniel arap Moi, who would later become the second president of Kenya was one of those who resisted British development policies in this district. In some cases, the opposition of these schemes forced the colonial governments to restructure the scheme. For example, the massive irrigation scheme launched by the French in the 1930s in Mali was reshaped by the Malian farmers. Monica M. van Beusekom in her book, Negotiating Development, ${ }^{55}$ shows how the French had intended this project to aid in the cultivation of cotton, the African farmers were able to change this crop to rice. For her, development was negotiated between the Africans and the French, though she would not go as far as to

\footnotetext{
53 Alden Young, "Accounting for Decolonization: The Origins of the Sudanese Economy, 1945-1964" (PhD Dissertation, Princeton University, 2013), 12.

54 Ibid., 20.

55 Monica M. van Beusekom, Negotiating Development: African Farmers and Colonial Experts at the Office du Niger, 1920-1960 (Oxford: James Currey, 2002).
} 
saying that this was a negotiation of equals. Her work exposes the difference between the ideology and the practice of development. The French ideology was that of social evolutionism and it was championed by the French experts. In practice, the Africans negotiated with the colonial experts and were able to modify the project.

Though several development policies of the colonial governments were resisted by Africans, many of these policies were continued in the period after independence. The new ruling elites saw these projects as a means of transforming their modernist aspirations into reality. In Mozambique, the Frelimo government, which had spent several years condemning Cahora Bassa, a dam project undertaken by the Portuguese, changed their position when they came to power six months after the dam was completed and Mozambique gained her independence. The new government now claimed that the dam would play a critical role in economic development and prosperity. ${ }^{56}$ In some cases, the new African leaders created replicas or resurrected schemes that had failed during the late colonial period. A good example is the Volta River Project to build Akosombo Dam started by President Kwame Nkrumah of Ghana. The Gonja Development Scheme had failed during the late colonial period.

The story of late colonial development in Nigeria shares common traits with what was going on in these other African colonies. Like some other colonies, Nigeria was also a test case of both scientific experimentation and social engineering. This literature is very important in my analysis of colonial development, most especially in the fourth chapter of my work in which I look at a specific development scheme, NAP. Also,

\footnotetext{
${ }^{56}$ Allen Isaacman and Barabara Isaacman, Dams Displacement, and the Delusion of Development: Cahora Bassa and Its Legacies in Mozambique, 1967-2007 (Athens: Ohio University Press, 2013), 4.
} 
development in Nigeria was a negotiation, albeit an unequal one between the Nigerian people, colonial government and Colonial Office. The contribution of my work is that it details the debates and discourse that shaped the plans. By going into the details of these discussions, it becomes obvious that development planning was a learning curve for the British. They did not have it all figured out.

The goal to develop the colonies and sustain empire was thwarted by some other problems that Britain was facing. In the late colonial period, Britain was struggling to hold onto most of her colonies amidst a rising tide of nationalist movements. She embarked on development not as an act of benevolence, but as a strategy for preserving and revitalizing empire. The Second World War was an economic disaster for Britain and there was an effective transfer of power in world affairs to the United States. The presence of the US in world affairs, most especially in developing nations, became more visible. This, as I will argue in this dissertation, was motivated by two factors: US interests in making these nations align ideologically with her and the cold war. Such an alliance with these nations had economic interest for the US as new markets were being opened for US goods. America's version of development is what has come to be known as modernization. The concept of development is broader than what modernization represents. As I have defined it in this work, it is an intentional act by the state to guide social, economic and even political progress. Modernization on the other hand was a historical process in which the economic, political and social structures and institutions of 
a traditional society were updated to achieve modernity and this modernity represented what was obtainable in America and most of Western Europe. ${ }^{57}$

Some scholars such as Nils Gilmans have argued that modernization theory was invented by American social scientists in the decade after the Second World War. He argues that at the heart of this theory was the goal of re-creating post-colonial states into the image of America. The theorists saw the problems in Africa, Latin America and Asia as problems that existed in the early years of the United States. They passionately believed that through socio-political and economic development, these nations would resemble the United States. In their view, the United States "could and should serve as a developmental model for the rest of the world. ${ }^{, 58}$ For Gilman, modernization was an invention of the United States in response to postwar challenges and opportunities. David Ekbladh challenges this view and pushes the origins of modernization to the pre-war period. He argues that in the 1910s and 1920s, there were already emerging new ideas of development that coupled modern applied technologies with the new social sciences. Though these ideas originated from outside the US, they had strong adherents in America. ${ }^{59}$ Ekbladh ties development to the ideological struggles of the twentieth century: liberalism, communism and fascism. The intervention by the US in world affairs was part of an ideological struggle over whose "ideologies were best suited to deliver the benefits of modern life. ${ }^{\prime 60}$ The ideas that would later be termed as modernization were not just invented in the period after 1945 . Neither was modernization theory created by

57 The fifth chapter will discuss in details modernization theory.

${ }^{58}$ Nils Gilman, Mandarins of the Future: Modernization Theory in Cold War America (Baltimore: John Hopkins University Press, 2003), 61.

59 David Ekbladh, The Great American Mission: Modernization \& the Construction of an American World Order (Princeton: Princeton University Press, 2010), 7.

60 Ibid.,2. 
the Cold War. These ideas worked their way into Cold War policies. ${ }^{61}$ Michael Latham in his 2011 book, The Right Kind of Revolution, agrees with Ekbladh on the pre-1940s origin of modernization. He argues that the American modernization that emerged had its basis in the thinking and of Woodrow Wilson and Franklin Roosevelt. He writes that the concern of these two with "the deeper, structural forces at work in world politics, and their commitment to a broadly internationalist vision linking U.S. security to the global environment, profoundly shaped the way that later policymakers tried to understand and respond to the impact of decolonization in the Cold War period."62 What Latham does in his book is to show how modernization was deployed across different regions of the world in the late 1950s and early 1960s.

The American vision of modernizing the world was unleashed on different parts of the world, India, Tanzania, Nigeria, etc. In the 1950s, American social scientists and policy makers came to view India as a model for the rest of the developing world. The reason was because of India's “democratic government - led by Westernized, noncommunist elites .... Its plans to raise citizens' standards of living through industrialization, state-led planning, and 'community development' held out the hope that other largely rural 'underdeveloped' nations could also escape a world of subsistence.",63 In line with the ideology of modernization, these social scientists believed that India's development vision captured the power of liberal democracies and free market capitalism

\footnotetext{
61 Ibid., 4.

62 Michael Latham, The Right Kind of Revolution: Modernization, Development, and U.S. Foreign Policy from the Cold War to the Present (Ithaca: Cornell University Press, 2011), 4-5.

63 Nicole Sackley, "Passage to Modernity: American Social Scientists, India, and the Pursuit of Development, 1945-1961” (PhD Dissertation, Princeton University, 2004), 2.
} 
to lift people from poverty and give them modern lives. ${ }^{64}$ Like India, modernization was brought to Nigeria by American social scientists that were in search of a model state for Africa. Discerning in Nigeria the kinds of democratic and economic values they saw in India, they believed Nigeria was "an exemplary nation in the making." ${ }^{65}$ Instrumental to the project of modernization in Nigeria was the first National Development Plan that was crafted by American social scientists associated with CIS. In his article "Bringing 'The Gospel of Modernization' to Nigeria: American Nation Builders and Development Planning in the 1960s," Larry Grubbs explores the impact of two American academics, Arnold Rivkin and Wofgang Stolper, on Nigeria's economic planning. Their planning had predicted an economically prosperous, democratic and unified nation-state that would become a model for other African nations, but this failed. They helped draft and implemented the first Nigerian National Development Plan, and five years into the plan, Larry Grubbs argues that "Nigeria's economy remained locked into neocolonial trade patterns, corruption blossomed, and ethnic conflict and political opportunism culminated in a bloody civil war from 1967-1970. Nigeria entered the twenty-first century with a staggering external debt, widespread poverty, and painful dependence on the West.",66 Grubbs believes that the crucial part played by Stolper and Rivkin in this nation building mission is the reason why personalities, specific institutions and the political context must be included in the new history of development. My work will expand the roles that these individuals together with CIS, played in the first Nigerian national development plan.

64 Ibid. 4.

${ }^{65}$ Larry Grubbs, “Bringing 'The Gospel of Modernization' to Nigeria,” 282.

66 Ibid., 279. See also, Larry Grubb, Secular Missionaries: Americans and African Development in the 1960s (Amherst: University of Massachusetts Press, 2009). 
Modernization's failure was not limited to Nigeria. By the 1970s, it had become obvious that the billions of dollars that had been poured by the United States into developing nations had not created "mini-American" nations. As Ekbladh states: "Statist programs, planning, and the large-scale transformation that had characterized modernizations heyday were viewed with a jaundiced eye. ${ }^{, 67}$ He believes that this was as a result of modernization's association with "Cold War thinking, ethnocentrism, and cultural imperialism." ${ }^{68}$ Amy Staples, in her book The Birth of Development, ${ }^{69}$ links the failure of modernization theory to the over reliance on technical experts rather than the innovations of the local people. There was the false notion that foreign experts recruited into the poor country would be able to use their technical expertise to transform the country. Some of these experts often ignored local knowledge; they believed that they knew best what was good for the people. The fifth chapter of this work, which looks at modernization in the Nigerian context, shows how the reliance on foreign planners mixed with some other local Nigerian conditions led to the failure of this ideology.

\section{Significance of the Research}

The field of development and modernization history is growing. Many of the works in this field are focused on Asia, Latin America, Southern Africa and Eastern Africa. Not many people have looked at West Africa as a whole and Nigeria in particular. As the review of scholarship above illustrates, when this region has been studied, the focus has been on economic development as a spontaneous process that economists and

\footnotetext{
67 Ekbladh, The Great American Mission, 10.

68 Ibid.

${ }^{69}$ Amy Staples, The Birth of Development: How the World Bank, Food and Agriculture Organization, and World Health Organization Changed the World, 1945-1965 (Kent, OH: Kent State University Press, 2006).
} 
other social scientists can study and measure, rather than development as an intentional practice that states try to make happen, that has a history we can study and analyze and learn from. My work uses history as a methodology to study development and development planning in Nigeria during the late colonial and early "postcolonial" period. This approach has not really been applied in the case of Nigeria. This work will offer a new perspective on the planning process and both the human, political and ideological sides of the planners.

Another significance of this research is that "postcolonial" African history is a growing field and more work needs to be done in the area. Given that the majority of African countries gained their independence only in the last sixty years, it is only now that most primary official sources are becoming available for researchers. Also, in "postcolonial" Nigerian history, Britain is no longer the only factor, but the United States as the new world power becomes a major factor. The role of the United States in the "postcolonial" development of Nigeria has been largely ignored by historians who write on Nigeria. My study will look at the role that both the United States and Britain played in using multi-year planning as a tool for development in late colonial and post-colonial Nigeria. Like the British, the US interest was not solely an attempt to stem communist influence. The US was interested in forging economic ties with Nigeria that would in turn be beneficial to it.

My work will make a major contribution to scholarship by bringing together two sets of literature: the literature on late colonial development and the literature on postcolonial Africa. This is important because it will help to shed light on the transition between British-led colonial development and American-led "postcolonial" development. 
By looking at planning in the late colonial period and planning in the early "postcolonial" period, my work will show areas of continuities and discontinuities in the planning process between the two periods and will reveal the ideologies that drove the planners. It will also show how regionalism coupled with ethnic biases affected the development process. Rather than placing the problem of underdevelopment solely on corruption, this study will show that there were other factors that impacted negatively on development. These are development ideology, human resources, financial resources, international experts/indigenous knowledge. 


\section{CHAPTER TWO}

\section{PLANNING DEVELOPMENT IN THE LATE COLONIAL PERIOD}

\section{Introduction}

The developmentalist state of the 1940s was one that held promising hope not only for the colonial governments but also for the Africans who became deeply involved in it even before they acquired power. ${ }^{70}$ Planning development and implementing the plans involved a series of negotiations between the metropole and the colonies. In the colonies, the state and also the nationalist leaders, farmers, workers and petty bourgeoisie, shaped the colonial plans. This was true of the 1945 Nigerian development plan in which a series of negotiations took place between Nigeria and the CO. At heart was the question of who should design and control development planning. Sidney Caine, who was in charge of colonial development policy at the $\mathrm{CO}$, argued that this form of planning should be controlled from the $\mathrm{CO}$ because the local colonial governments "did not have the time, and in many cases the experience and expertise, necessary to carry out the daunting task of continuous, systematic planning." 71 While Caine's view of a metropolitan approach to development was under consideration, some other senior staff of the $\mathrm{CO}$ believed that it was important to bring the local colonial governments to the planning process because they had a better understanding of the local circumstances. In order to bridge the gap between what was happening in the metropole and colonies, it

\footnotetext{
70 Cooper, African Since 1940, 44-45.

${ }^{71}$ Hodge, Triumph of the Expert, 199.
} 
was decided that a planning section should be created within the $\mathrm{CO}$ and there should be a buildup of technical staff at the $\mathrm{CO}$ that would make regular visits to the colonies and provide them expert advice. Also it was decided that regional development organizations be created and the territories should set up planning councils or committees that would carry out long-term planning. ${ }^{72}$ In this chapter, I look at how the 1945 Nigerian plan came to be. I argue that the metropolitan-centered development mission favored by Caine was limiting to development in Nigeria because the colonial administration in Nigeria was the one that had to implement the plan and it knew better the needs and limitations of the local conditions. The colonial state was under the critical purview of Nigerian elites and the local press and this factor helped to limit and shape the development agenda of the state.

I also argue that the Nigerian colonial officials were well intentioned in their attempt to carry out development in the colony. They had given serious and considerable thought to development in the colony and had setup institutions of development from the district level through the provincial level to the central level. These institutions were setup to generate ideas that would help to develop the colonies and also to help identify schemes that would be most beneficial. Also, as a sign that the colonial state was well intentioned in its goal of developing the colony, the Nigerian officials saw agriculture as a key to the economic success and so at the beginning of the plan's implementation, they wanted to invest heavily on agriculture through extension and colonial personnel in order

72 Ibid., 201. 
to stimulate production and generate revenues which would help to sustain the plan beyond ten years.

Despite the strengths of the 1945 plan, I argue in this chapter that it had serious limitations and shortcomings. One factor that affected this plan was that it was not well funded. The $\mathrm{CO}$ had grossly underestimated the financial resources that were needed in order to achieve the level of development that they had envisioned. The figure that both the $\mathrm{CO}$ and British Treasury agreed upon for development of the colonies was at best an educated guess. Two reasons were responsible for this: planning was still very new and they had not devised a way of measuring effectively needs and outcomes. The second reason was because Britain did not have the financial resources as it was emerging from the Second World War and was undergoing reconstruction and reinvestment. And the other important factor that affected the planning process was the lack of involvement of Nigerians in the planning bodies that were set up and in the government services, such as the development officers. At the heart of the colonial state was racial bias. This prevented Nigerians, who could have served in different capacities, from directly promoting development. This systemic racism that clouded the colonial state hindered progress both in the development and implementation of the plan.

\section{Colonial Development Before 1929}

Prior to the Great Depression, Britain was engaged in some form of development in the colonies. The person who put imperial development on the table was Joseph Chamberlain. When he became S of S for the colonies in 1895, he was aware of the fact that some tropical colonies were decaying while others were thriving. He believed that 
the key to the restoration of Britain's power, wealth and prestige, which he feared were waning, was imperial union and development. ${ }^{73} \mathrm{He}$ was also aware of the fact that plenty of resources would be needed in order to maintain and defend an empire so big as that of Britain. The solution to this problem was the need for "prosperous and contented subjects within all parts of the empire, Crown colonies as well as dominions, which were capable of raising sufficient revenues, both to contribute to the defense of their territories, and to generate sufficient investment capital to set their domestic economies on a path of selfcontinuing growth." ${ }^{74}$ Chamberlain's vision was that imperial funds should be made available for the development of the colonies both for the betterment of the colony itself and the empire as a whole. His efforts were constantly fought back by the Treasury, which saw it as an anathema to spend imperial funds in the development of the colonies. The view obtainable at the time was that the colonies needed to develop themselves economically through private capital.

Though Chamberlain had placed colonial development on the table in the late nineteenth century, it was only by the 1920s that attempts were made at institutionalizing colonial development. Early in the 1920s, L. S. Amery, who was the Parliamentary Under-secretary of State for the Colonies, and Lord Milner, who was the S of S, championed colonial development. They saw the economic development of the colonies as the only answer to Britain's economic problems. After the First World War, Britain's debt was rising greatly and it cost $£ 210$ million to service that debt annually. There was need for fresh sources of revenue in order to reduce the burden of taxation that was going

\footnotetext{
${ }^{73}$ Havinden \& Meredith, Colonialism and Development, 87.

${ }^{74}$ Ibid.
} 
to be placed on industry and the investment class. A corollary benefit to this was full employment for British workers. ${ }^{75}$ Amery argued for the "extension of tariff protection with imperial preferences and the sustained funding of empire settlement programs.",76 However, the Treasury ministers and officials opposed Amery's views on colonial development. These officials argued that money invested in the colonies by way of development would never be recovered. Nevertheless, the $\mathrm{CO}$ pushed its plans. The policy at the time was that colonial development aid should be in the form of loans rather than grants. ${ }^{77}$ The struggle between the CO and the Treasury was so fierce that in 1928 , Amery then $\mathrm{S}$ of $\mathrm{S}$, sent a letter to Stanley Baldwin, the prime minister, in which he wrote, "Four years bitter experience have convinced me that any attempt to help the employment situation here by accelerating Colonial development is hopeless as long as matters are left to the Treasury, which is at bottom against all expenditure, whether on development or on anything else, and whose powers of obstruction are infinitely greater on an Imperial subject than on a domestic issue where there is constant parliamentary pressure." ${ }^{, 78}$ This was the period shortly before the Great Depression.

\section{The 1929 Colonial Development Act}

During the Great Depression, the economic importance of the empire was heightened. Empire was seen as a "safety cushion during hard times, a domain to be

\footnotetext{
75 Stephen Constantine, The Making of British Colonial Development Policy, 1914-1940 (London: Frank Cass, 1984), 36-37.

${ }^{76}$ Ibid., 164.

${ }^{77}$ Neal R. Malmsten, "British Government Policy Toward Colonial Development, 1919-39," The Journal of Modern History 49, 2 (1977): 1250.

${ }^{78}$ Amery to Baldwin, 26 November 1928, The National Archives, Kew, Colonial Office Records (Hereafter TNA CO) 323/1016/51165, Quoted in Constantine, The Making of British Colonial Development Policy, 168.
} 
isolated from global economic competition in the interest of Britain." ${ }^{79}$ Prior to the economic depression, the colonial state in Nigeria, for example, was able to balance its budget through the export of agricultural products and tin mining. In the 1920s, half of Nigeria's exports were palm products. ${ }^{80}$ The depression affected both the agricultural industry and the mining industry. World demand for primary products fell by 50 percent, which led to falling prices for exports. Price reductions had a devastating impact on the economy of Nigeria and the colonies that were primary producing economies. L. J. Butler writes, 'the price paid to Nigeria's palm-oil products dropped by almost 80 per cent between 1928 and 1934, and the total value of Nigerian exports fell from $£ 16,927,000$ in 1928 to $£ 8,560,000$ in $1933 .,{ }^{, 81}$ The depression also affected imports. European goods were no longer imported in the same quantities that they had been imported before the depression. The revenues of the colonial state that were derived from custom duties on imports and exports, as well from the taxation of Africans through the hut and poll tax, dried up. The limited revenues acquired through export trade were used to pay debt charges. The local governments could not get help from London because colonies were expected to be financially self-sufficient. The implication of these factors was that colonies like Nigeria did not have the revenues to develop their territories. Most important for this study, two major problems were emerging at this time: the unemployment in Britain and the lack of development that was taking place in the colonies.

\footnotetext{
${ }^{79}$ Ochonu, Colonial Meltdown, 27.

${ }^{80}$ L. J. Butler, Industrialisation and the British Colonial State: West Africa, 1939-1951 (London: Frank Cass, 1997), 15.

${ }^{81}$ Ibid., 15-16.
} 
It was thus not surprising that these imperatives found expression in the first attempt to institutionalize colonial development in the form of the 1929 Colonial Development Act. The act was a public works program with the aim of alleviating the problem of unemployment in Britain. As the 1929 elections drew near, there was pressure on Winston Churchill, the Chancellor of the Exchequer, to support the policy of colonial development as the Conservative Party would be severely criticized by the opposition parties for doing nothing to reduce unemployment. While Churchill, a former S of S, dismissed the CO's pressure, by May of 1929, Baldwin “included Amery's recommendation of a colonial development fund and advocated the extension and expedition of development policy in Africa, but in accordance with a cabinet decision he left open the question of the machinery for the administration of the fund." 82

However, Baldwin's government suffered defeat in the elections and had to resign on 4 June 1929. The Labour Party, which formed a minority government, had campaigned on the platform of tackling the problem of unemployment. The colonial secretary of Labour's government, J. H. Thomas, was an enthusiastic supporter of the idea that colonial development would alleviate unemployment in Britain. Amery found an ally in Thomas and drew his attention to a Conservative Party proposal, which called for the creation of a development fund. The Labour Party picked up this proposal and quickly turned it into legislation. ${ }^{83}$ The $\mathrm{CO}$ under Thomas defined what they considered an acceptable colonial development fund scheme. Stephen Constantine writes: "Since the purpose of the scheme was to induce colonies to undertake works, with which they would

\footnotetext{
${ }^{82}$ Malmsten, "British Government Policy," 1265.

${ }^{83}$ Constantine, The Making of British Colonial Development Policy, 183.
} 
otherwise not at present burden themselves, in order to accelerate the revival of industry at home, it was essential that there must be an element of free gift to the territory. This should take the form of a contribution of the whole or part of the interest on a loan for a certain number of years. ${ }^{\prime 84}$ The Treasury remained skeptical of the value of this scheme in reducing unemployment. Nevertheless, Thomas on 24 June 1929, requested the CO, the Treasury, and parliamentary counsel to prepare a bill. This bill was complete by 26 June 1929. The bill moved fast through the parliament and received the Royal Assent on 26 July $1929 .{ }^{85}$

The resulting 1929 Colonial Development Act was a failure. It failed primarily because of poor planning and limited funding. Only $£ 1$ million was available annually to fund the ten colonies that were part of the scheme. Between 1930 and 1940, Nigeria received about $£ 330,000$. Of this amount, “£114,450 (or 34.7 percent) was granted to pay interest on loans for the construction of the Minna-Kaduna railway, £51,000 funded the organization of ground facilities for air services, and $£ 95,000$ facilitated research and treatment of sleeping sickness. Agriculture received $£ 3,400$ to encourage mixed crop farming and another $£ 1,500$ on tsetse fly research, while the rest went for other small expenses.. ${ }^{86}$ True to its intention, it was a job program for the British and not an act that brought about any significant development for the colonies. $£ 330,000$ for a colony the size of Nigeria was a paltry sum. This act is in stark contrast to the 1945 legislation that saw the approval of $£ 55$ million to Nigeria for a ten-year period.

\footnotetext{
${ }^{84}$ Ibid., 184.

${ }^{85}$ Ibid., 185.

${ }^{86}$ Falola, Development Planning and Decolonization in Nigeria, 14.
} 


\section{Planning Development, the 1940 Act}

The economic depression that started in 1929 created deplorable conditions in the colonies. As the depression deepened, the social and economic conditions in the colonies were getting worse rather than better. Joseph Hodge writes that, "Deteriorating conditions in the colonies, critics charged, were evidence of years of complacency, neglect and exploitation. New attitudes were taking shape that by the end of the decade would usher in a far-reaching process of colonial reform, symbolized by the passing of the Colonial Development and Welfare Act of 1940." ${ }^{87}$ These social and economic conditions led to unrest and riots in the colonies and questions were asked in the metropole about the conditions in the colonies. The attempt to find solutions to the conditions in the colonies formed the backdrop of the 1940 act. Unlike the 1929 act, the word "welfare" was now added. The significance of this was that colonial development now had as part of its mission, the improvement of the social conditions of colonial people. The 1940 Act marked a major shift in colonial development policy. With this act, the British government placed importance on tackling the problem of colonial poverty. Thus, this act emphasized welfare provisions over economic development. Alleviating colonial poverty became a major goal designed to inoculate Britain from the United States's critique of colonial rule. It is important to note that despite the fact that this act was intended to be more humanitarian than mercantilist, measures that would bring about economic development were still promoted at the insistence of the Treasury. Treasury's argument was that economic development would enable colonial governments to provide essential

\footnotetext{
${ }^{87}$ Hodge, Triumph of the Expert, 145.
} 
social services. Butler argues that this idea did not please many at the Colonial Office. ${ }^{88}$ Unlike the 1929 act that allocated only $£ 1$ million annually for the development of colonies, the 1940 act allocated $£ 5.5$ million annually for the colonies. Of this amount, $£ 500,000$ per annum was allocated solely for research in the colonies. ${ }^{89}$

The Governor of Nigeria, Sir Bernard Bourdillon, was excited about the passage of the 1940 Act. He had been instrumental to the vigorous debates that were taking place in the $\mathrm{CO}$ on the nature of the Act. He had sent a long dispatch to the $\mathrm{CO}$ blasting "the established notions of financial self-sufficiency and damned the Colonial Development Act [of 1929]for its inefficacy. He lamented the problems of poor territories like Nigeria which, were burdened by debts, could not raise enough extra local revenue to meet the interest on new loans or to face the recurrent expenditure which development works often entailed." 90 Bourdillon concluded his dispatch by requesting that development loans should be granted by London on reduced interest rates and the development of the departments of agriculture, forestry, veterinary, geological survey and co-operatives be fully financed by the Imperial Government. ${ }^{91}$

His excitement is understandable because this was the first time that the British imperial government committed substantial financial aid to the colonies for their development and welfare. He had long disdained the philosophy that the colonies had to be self-sustaining. He wasted no time promoting the legislation among his officials and asking the various Residents of the provinces to submit proposals for development. Not

\footnotetext{
${ }^{88}$ Butler, Industrialisation and the British Colonial State, 21.

${ }^{89}$ Falola, Development Planning and Decolonization in Nigeria, 24-25.

${ }^{90}$ Constantine, The Making of British Colonial Development Policy, 244.

91 Ibid.
} 
much guidance was given on how to proceed. The Residents in turn asked for statements of needs from the departments, district officers, etc. These initial proposals were ambitious and not very well planned.

It was only after the $\mathrm{CO}$ established the Colonial Economic Advisory Committee (CEAC) in September of 1943 to advise the S of S on development in the colonies that guidelines were written on how to proceed with development planning. These guidelines encouraged the formation of economic advisory committees in the colonies. ${ }^{92}$ In August of 1943, the Nigerian colonial state established the Advisory Committee on Economic Development and Social Welfare. This committee, which was headed by T. HoskynsAbrahall, had its first meeting on August 5, 1943. The committee assisted in coordinating the different proposals that would later form the bulk of the ten-year development plan. Besides this committee, which was headquartered in Lagos, there were other committees that worked at a more local level. Provincial development committees were present in all twenty-three provinces of Nigeria. These committees were comprised of both official and nonofficial members. The official members were heads of departments while the nonofficial members, who were mainly Nigerians, were chosen by the Residents to represent the different interest groups. ${ }^{93}$ The role of the provincial development committee was to "coordinate the activities of the various departments, reduce the workload of the Resident in matters relating to the Colonial Development Fund, make suggestions on projects and prepare schemes on its own initiative." 94 The provincial development committees were not at the bottom of the bureaucracy. There was still

\footnotetext{
${ }^{92}$ Falola, Development Planning and Decolonization in Nigeria, 26-28.

${ }^{93}$ Ibid., 29-30.

${ }^{94}$ Ibid., 30.
} 
another level below. This was the divisional development committee. The District Officer usually chaired this. Members of this committee included "a few high-ranking chiefs, the District Officer, and senior officers of the Health, Agriculture, and Public Works departments. The divisional development committee also involved interest groups, such as the Christian missions, foreign firms, and a few educated elites." 95

This bureaucratic structure was in place by the end of the Second World War, and most of these committees had submitted numerous proposals to the advisory committee in Lagos with the hope of benefiting from the 1940 CD\&W act. The development plan that arose after the passage of the 1945 Act had its foundation in the proposals that the advisory committee had received prior to 1945. Much of the thinking embodied in these plans stretch back to the 1930s when the colonial state started thinking seriously about development in response to the depression. The state experimented with different things such as mixed farming and extension services, as a way of increasing productivity and raising revenues. One can rightly argue that these ideas were now crystalized into development proposals during wartime. During the war, the implementation of the 1940 act was suspended and the colonies had to wait until the end of the war in 1945 when the act was revised and substantially enhanced to $£ 120$ million. The development proposals that were formulated during wartime by the provincial committees were not based on any carefully thought out long term development strategy. This approach changed with the 1945 Act. The plans were prepared at the departmental level and then subsequently coordinated. This is how the plan was put together: "Each department had accordingly

\footnotetext{
${ }^{95}$ Ibid., 30.
} 
been asked to put up a ten-year plan based on what it considered to be essential development in its own sphere. In order that there should be no departmental competition, no department except the Public Works Department was allowed to know the financial implications of the other departments' plans. There had been no question of allowing each Department a percentage of a given figure. The proposals were then coordinated and modified as necessary." ${ }^{, 96}$

The original development proposals for the postwar that the Nigerian government sent to the CO in 1944 laid out plans for a fifteen-year period. Initially, the plan was to last for ten years beginning from 1945, but this was changed to a fifteen year period because the authors feared a shortage of staff in the post-war period and saw the necessity of building each service gradually, thereby leading to a longer completion period. ${ }^{97}$ While the $\mathrm{CO}$ accepted the Nigerian development plan of fifteen years in principle, it made clear that the CD\&W Act as envisaged could only cover ten years. The Nigerian plan was to be divided into three sections, each lasting for a period of five years. The CD\&W funds would cover the first ten years of the program but the last five years would be dependent on assistance from the $\mathrm{CO} .{ }^{98}$ This preliminary plan of development covered three main areas: capital works, government services, and economic development. Projects that fell under capital works were water supply, roads, telecommunications, electricity, and the improvement of African housing. Development projects that were to be carried out under government services were the expansion of medical, agricultural,

\footnotetext{
${ }^{96}$ Planning \& Reorganisation Development Proposals. Extracts from notes of a discussion with the Treasury on 9 November 1944, TNA: CO 583/271/4.

${ }^{97}$ F. E. V. Smith, Memorandum on Nigeria's Preliminary Development Plan, 3 October 1944, TNA: CO $583 / 271 / 4$.

${ }_{98}^{5}$ Ibid.
} 
veterinary, forestry, research, and social welfare services. For economic development, the emphasis was placed on the provision of adequate marketing services covering as many Nigerian products as possible..$^{99}$

This plan did not place much emphasis on economic development. The writers of the plan were not unaware of this weakness. The Nigerian planners believed that it was important to have some basic social services in the plan without which it would be difficult to have a good economic plan. F. E. V. Smith, the development secretary in Nigeria, argued in a meeting with the Treasury in London on 9 November 1944, "The fundamental necessity was not so much development as welfare and spectacular development could not be looked for until the basic necessities of life had been provided; when this was done the productive capacity of the people as a whole could be improved and could be absorbed into some form of economic development." ${ }^{100}$ Sydney Caine ${ }^{101}$ and the Treasury, on the other hand, wanted a greater emphasis on increasing production and economic growth. Caine argued that development in the past was found through private individuals who were economic prospectors. In the future, this was not going to be possible because of conditions of taxation and control of capital markets. This meant that the state had to undertake the role of economic prospectors. He wrote, "If it is going to do that effectively and intelligently, it must develop machinery for doing the economic prospecting which was formerly done by large numbers of private persons acting on their

\footnotetext{
99 Ibid.

${ }^{100}$ Planning \& Reorganisation Development Proposals. Extracts from notes of a discussion with the Treasury on 9 November 1944, TNA: CO 583/271/4.

${ }^{101}$ Sydney Caine was appointed financial adviser to the colonial office in 1942 and was in charge of colonial development policy from April of 1943. He was Assistant under-secretary of state from 1944 to 1947.
} 
own account."102 Caine's view of development was one that was mainly economic in character. $^{103}$

What was at stake here was the clash of development ideologies. Smith's view was based on the basic needs ideology, which was championed early on in colonial development policy by Chamberlain. In order to unleash the productive capabilities of the colonial period, it was important that the populace be provided with basic needs. If the people were contented and prosperous, then you could require more from them, which could contribute positively to the economy. On the other hand, Caine's view was that the foundation of development was economic growth and productivity. Through these, resources are produced that allow the colony to invest in social services such as education, health, etc. The question is, what comes first: welfare or development? For Caine, it is development and for the Nigerian officials, it was welfare. Caine's view of development was narrow. Without a strong educational and health system, you cannot have a strong economic system. His views did not take into consideration the long-term economic development of the colony.

\section{The 1945 Act and Development Planning in Nigeria}

The period after the Second World War was an important phase in British colonialism in Africa. The war interrupted the implementation of the 1940 act. As the attention of London turned toward the war, colonial development as envisaged by the act was suspended. This period marked the rise of the decolonization movement and the

\footnotetext{
${ }^{102}$ Memorandum by S Caine, 12 August 1943, TNA: CO 852/588/2, in S. R. Ashton and S. E. Stockwell, eds. Imperial Policy and Colonial Practice, 1925-1945 (London: HMSO, 1996), 168.

${ }^{103}$ Ibid.
} 
beginning of what has been called the "second colonial occupation." This "occupation" was an attempt to stem the tide of decolonization by improving social services for the colonial people and also as a way to improve the economy of Britain that had been devastated by the war. The Second World War left a devastating impact on the economy of Britain. The war had affected both colony and metropole not only economically but also socially and psychologically. While there was social unrest in the colonies, Britain also had to find a way to deal with her economic problems at home. London turned toward the colonies for its economic salvation. It was believed that if the resources of the colonies were extracted, these would be good for Britain's economy and also for the colonial people. However, if Britain was to hold onto her empire, it was important for the colonies to be developed.

During the war, there were plans for parliament to update the $1940 \mathrm{CD} \& \mathrm{~W}$ act. The Nigerian colonial state was also envisioning ways for updating the development proposals that they drafted in light of the 1940 act. Governor Arthur Richards, in May of 1943, set up a central committee called the Advisory Committee on Economic Development and Social Welfare. This committee had as its chairman, the chief secretary to the government. Other members of the committee included the commissioners of each of the three regions, the financial secretary, the director of medical services, the director of education, the director of agriculture, the director of public works, the chief conservator of forests, the commissioner of labor, the director of veterinary services and three members of the Legislative Council. This committee met in August of 1943 to plan 
postwar development in Nigeria. At their meeting, they came up with a seven point agenda for development:

1. The settlement of ex-soldiers. This was to be undertaken by the development branch in conjunction with the department of labor.

2. Rural land planning and development. The focus here was land utilization and degradation; land settlement and irrigation. This was to be handled by the provincial committees.

3. Economic development of livestock. The directors of agriculture and veterinary services were to form a sub-committee to work on this.

4. Urban land planning. Work had already been done on this in Lagos. It was to be expanded colony-wide.

5. Mineral development. This was already part of the war effort and they believed that all that was possible was already being done.

6. Secondary industries. This subject was already being taken up with the Resident Minister. ${ }^{104}$

7. The examination of all works and schemes proposed by any department of government. The task of the development organization was to take all the different programs of postwar reconstruction and prioritize them and advise on applications for CD\&W grants. ${ }^{105}$

Governor Richards also established a development committee in each of the 23

provinces of Nigeria. The officials in Nigeria were excited about development in the colony and they wanted the machinery of development in Nigeria to be ready once the new act was passed. F. E. V. Smith was in charge of the development department and Governor Richards had plenty of confidence in him. The development department had the responsibility of conveying instructions from the central government to the chief commissioners and provincial committees and also providing them with assistance and information. The governor sent the first development proposals that would fall under the new act to London on the 22nd of September 1944. These were sent to the $\mathrm{S}$ of $\mathrm{S}$, Colonel Oliver Stanley, to enable him discuss them with his advisors in preparation for

\footnotetext{
${ }^{104}$ Noel Hall was the Resident Minister, West Africa and he was in Achimota, Ghana.

${ }^{105}$ Richards to Stanley, 7 January 1944, TNA: CO 583/271/4.
} 
Smith and H. E. Walker's visit to London. ${ }^{106}$ Governor Richards' confidence in Smith and his eagerness to begin development in earnest under the new Act is seen in his letter to the S of S. He wrote: "Mr. Smith has been instructed that he has my full authority and a free hand to discuss and modify the proposals in any way necessary in order to reach agreement with your advisers, and I trust that it will be possible for him to return with a sufficiently definite approval of these plans for action to be taken locally at the earliest date." 107

This was the beginning of a long journey in planning in Nigeria for the 1945 act. The rest of 1944 and most of 1945 would be spent in development planning. On the $30^{\text {th }}$ of September 1944, the Resident Minister, Noel Hall, sent a letter to the S of S endorsing the preliminary outline for development emanating from Nigeria. He considered the general framework of the plans as being sound. ${ }^{108}$ Meanwhile, Smith and Walker arrived London and several discussions were carried out with officials at the CO. By the $20^{\text {th }}$ of October 1944, discussions had reached a point in which certain decisions needed to be made. Seven issues arising from the meeting needed to be decided upon. The first was the approval in principle of the outline development plan and the revised rough estimates; the second was an agreement in principle that Nigeria would receive $£ 27$ million during the period between 1946 to 1956; the third was the approval of the general principle that the CD\&W vote would service loans collected by Nigeria for development during the years covered; the fourth was on the provision of $£ 375,000$ from the CD\&W vote for the period

\footnotetext{
${ }^{106}$ F. E. V. Smith, C.M.G was the Head of the Development Branch of the Secretariat and H. E. Walker, C.B.E. was the Deputy Director of Public Works. Walker had collaborated in the preparation of the proposals and he had a wide knowledge and a long experience in Nigeria.

${ }^{107}$ Richards to Stanley, 22 September 1944, TNA: CO 583/271/4.

108 Hall to Stanley, 30 September 1944, TNA: CO 583/271/4.
} 
from 1944 to 1946 to enable initial preparations in anticipation of the main schemes being approved; the fifth was approval for the establishment of a development commission; the sixth was agreement for the hiring of development officers to begin immediately and that their salaries be paid by the CD\&W vote; and the seventh was agreement on the establishment of a department of commerce and industries which would help to foster and finance local industries. ${ }^{109}$

A meeting was held on the $25^{\text {th }}$ of October 1944 to discuss the Nigerian development proposal and to make a decision on the seven issues raised above. The $\mathrm{S}$ of $\mathrm{S}$, who was present at the meeting, did not think it was necessary to discuss in details the development proposal since Governor Richards was arriving in London soon. He saw it necessary that the proposal be discussed in details when the governor was present in London. The $\mathrm{S}$ of $\mathrm{S}$ was impressed with the general design of the development framework and wanted it to be crafted comprehensively. Frederick Pedler, ${ }^{110}$ however, felt that there was a difficulty in justifying the allocation of $£ 27$ million for the ten years to Nigeria. His reason for objecting was based on the total amount that was available for development in all the colonies. At this time, the $\mathrm{S}$ of $\mathrm{S}$ was planning to ask for $£ 150$ million for development. This amount for Nigeria constituted $18 \%$ of the total allocation. Given the size of Nigeria and its significance to the empire, that amount was not too big. As the $\mathrm{S}$ of $\mathrm{S}$ rightly pointed out to him in justification of the sum, Nigeria represented a third of the colonial empire. The S of S also agreed that an application should be made

${ }^{109}$ Minutes of a meeting held at the Colonial Office, 20 October 1944, TNA: CO 583/271/4. ${ }^{110}$ Frederick Pedler worked in the finance department of the Colonial Office at the time of these negotiations on the Nigerian plan. Before this current position, he was British Economic Representative in Dakar, Senegal. 
for the provision of $£ 735,000$ to cover the initial preparations in anticipation of the main schemes. The meeting also discussed the proposed appointment of a development commission. The reason given for the necessity of the commission was that it would secure continuity of policy. It was argued, "The existence of a statutory body would ensure that changes in policy were not lightly made with every change in tenure of the higher offices of Government. The Commission would also be able to watch over the transition of policy into action and to ensure that continuity was also maintained in spite of changes at lower levels. There would be the added advantage that a commission would possess the standing and authority necessary for dealing with the Chief Commissioners."

In the event, the $\mathrm{S}$ of $\mathrm{S}$ expressed doubts about the appointment of a statutory board. He did not find the continuity argument convincing. The members of the commission would be as subject to change as individual government officials. He also had questions about the relationship between this commission and the chief commissioners. This was because recent constitutional proposals from Nigeria favored regional decentralization. The commission proposed would actually create centralization and not decentralization, thereby causing bureaucratic bottleneck. He also argued that creating such a board would lead to Nigerians clamoring for unofficial representation and this would be impossible to meet because it was believed at the time that no Nigerian was capable of seeing the interest of Nigeria as a whole. Sir George Gater ${ }^{112}$ also thought that creating such a commission outside of the secretariat would create administrative

111 Notes of a meeting held in the Secretary of State's Room to discuss the Nigerian Development proposals, 25 October 1944, TNA: CO 583/271/4.

112 Sir George Gater was the permanent under-secretary of state. 
difficulties. The reason he gave was that it was impossible to separate new development from existing services. It was decided at this meeting that a decision should not be made but that the issue should be further discussed with Governor Richards. The final point of discussion concerned the appointment of development officers. It was agreed that they should be appointed on a short-term basis without any promise of permanent appointment to the administrative service. ${ }^{113}$ Though the local administrators knew better the circumstances which they operated under, the metropolitan government was attempting to make the decisions. It is however important that they deferred to the arrival of the governor in London for some decisions to be made. In this way, they wanted to take into consideration the governor's own viewpoint. This was in line with the earlier decision to bridge the gap between metropole and colonies.

With the arrival of Governor Richards in London, a meeting was held on 6 November 1944, to discuss Nigeria's preliminary development plan. The S of S was pleased with the preliminary development proposal from Nigeria and he "fully approved the general design of the Nigerian scheme which he thought was excellent. It was much better to prepare a comprehensive framework on those lines within which detailed schemes could be co-ordinated subsequently than to continue to submit un-correlated small-scale schemes for individual projects." 114 The development plan that Nigeria submitted and was being discussed, required an assistance of $£ 55$ million to cover the fifteen-year period. When it was concluded that the CD\&W Act would only cover a tenyear period, the financial cost of the plan was readjusted after discussions between the

113 Notes of a meeting held in the Secretary of State's Room to discuss the Nigerian Development proposals, 25 October 1944, TNA: CO 583/271/4.

114 Ibid. 
$\mathrm{CO}$ and Smith. The S of S gave a general approval for the sum of $£ 27$ million from the $\mathrm{CD} \& \mathrm{~W}$ vote. Nigeria was to finance a further $£ 8$ million through loans. The loans were expected to cover projects that would become self-supporting. The $£ 27$ million approved also included the annual charges on the loans covering the initial five years. The projects for which a total of $£ 35$ million was approved were projects that were to be financed through the CO. Nigeria was also to make a substantial contribution to the development of the colony through its own funds. Nigeria was to finance development in the areas of ports and marine, inland water transportation, postal service, police, labor, part of the geological survey, some administrative service, housing of African staff, pensions of African staff, accounting, audit and African clerical services needed for the program. ${ }^{115}$ The goal was that at the end of the ten-year period, Nigeria would be in a position to continue to fund the recurring commitments that the development program created.

Though the S of S gave an approval of the general outline of the Nigerian plan, Governor Richards wanted more. He sought the approval for the publication of the general scheme as soon as it was possible. The $\mathrm{S}$ of $\mathrm{S}$ agreed with him and said it was important for this to be done as soon as possible because he considered the Nigerian plan "as a model for comprehensive outline development schemes." 116 The S of S, however, told the governor that approval couldn't be granted at the present time because he had not settled with the chancellor of the exchequer on the amount that would be made available in the CD\&W Act. He also left open the possibility that the Nigerian plan could be scaled

${ }^{115}$ F. E. V. Smith, Memorandum on Nigeria 's Preliminary Development Plan, 3 October 1944, TNA: CO 583/271/4.

116 Notes of a meeting held in the Secretary of State's room on Nigerian preliminary development plan, 6 November 1944, TNA: CO 583/271/4. 
down if the act did not make available the sums he had envisaged. It is important to note that all these discussions were taking place prior to the 1945 Act. The S of S was planning to ask for $£ 150$ million for development in the colonies for ten years. As we will see shortly, he could not secure that amount from the Treasury.

The question of a statutory commission that would oversee development in Nigeria was also a topic of discussion at the meeting with the governor. In the October meeting, a decision was put off awaiting the governor's arrival in London. Prior to the meeting, the governor discussed the matter with Gater, who expressed doubts about the value of such a commission given the administrative difficulties it may cause, but who had also left open the possibility of a coordinating machinery that would oversee the schemes. Governor Richards came to an understanding with Gater at the $6^{\text {th }}$ November meeting in the S of S's room that he was prepared to drop the idea of a statutory development commission. What he would rather have asked for was that there should be a development secretary who should be in charge of the whole development program and also a central coordinating committee that would have as its chairman the development secretary. ${ }^{117}$ All of this was new to both London and Nigeria, but it is also obvious that the governor and his officials had been thinking about this for awhile and were looking for an efficient way of carrying out development in the colony. The governor wanted a statutory board and the $\mathrm{CO}$ officials were concerned about the bureaucratic bottlenecks it may cause because Nigeria's constitutional development at this time had favored decentralization. At the same time, it was important to have a coordinating machinery in

\footnotetext{
117 Ibid.
} 
place so that the plans were not disparate and there was unnecessary duplication and wastage. Though the governor did not get his statutory board, which would have been bestowed, with more authority, he was willing to accept a committee with a lot of authority vested in Smith, his development secretary and trusted ally.

\section{African Labor and the Color Line}

One of the major components of the Nigerian development plan was the appointment of development officers. Governor Richards saw them as an essential part of the program. Smith thought that without them, it would be impossible to carry out development work in the provinces. While there were provincial development committees already in existence, the governor felt that there was need for development officers whose job it was to work out the plans and also to see to their execution. These officers, who were to be appointed on a temporary basis, were to fill in the gap that the administrative staff could not. As envisioned by the Nigerian colonial state, they had principally four functions: 1 . To relieve administrative and technical staff of their routine duties; 2. To help with fieldwork in connection to local planning and execution of development schemes; 3. To supervise the execution of development schemes under directions of the local administration or technical officers; 4. To train African staff in the duties of development officers. ${ }^{118}$ The need for these development officers arose because in the post-war period, there was going to be a dearth of manpower in Nigeria. In a memo, the Nigerian colonial government argued thus for the need for development officers:

118 Ibid. 
...the administration lacks the resources in manpower under present conditions to deal with the vast amount of subordinate work, both in planning and the execution of plans, which will be required. It is already over twenty-five per cent down on its established strength and will be further heavily depleted at the end of the war when large numbers of officers are due to retire....It is clear therefore that it will take a considerable time after the war to bring the administration up to its necessary strength, even without taking into account any extra requirements for the development programme. It follows that, if adequate staff is to be provided in the immediate post-war period for the subordinate work on the planning and execution of development schemes, it will be necessary to resort to some other method of recruitment for the administrative service on a permanent basis. ${ }^{119}$

It was easier to fill the temporary positions of development officers than it was to fill the positions of administrative and technical staff. The net was to be cast wide to recruit the 100 development officers that were needed. Given that the war had not ended, Nigeria believed that it was going to be impossible to recruit these men immediately. However, they needed to recruit about 35 men immediately and they looked to the United Kingdom to recruit these men. There was a general agreement between the $\mathrm{CO}$ and the Nigerian officials on Nigeria's request for development officers. The only area of concern was the title of "development officer" which they agreed that it was not an ideal one, yet they had not been able to come up with another title that may be attractive enough for good men to be encouraged to apply for the position. ${ }^{120}$ The qualifications for a development officer were set very low. What the Nigerian government was looking for in development officers were men of "good background and intelligence, with initiative, honesty and the ability to follow single instructions." ${ }^{121}$ In Smith's earlier memorandum to the $\mathrm{CO}$, he had given the qualifications outlined for a development officer as "a man of

119 F. E. V. Smith, Memorandum on Nigeria's Preliminary Development Plan, 3 October 1944, TNA: CO $583 / 271 / 4$.

120 Ibid.

121 Ibid. 
good background, preferably with a liking for a country life, but not necessarily possessing the full academic qualifications which would be required for permanent appointment." ${ }^{, 122}$ It is important to note that Africans were not under consideration for the position of development officers. Though the qualifications were low, Africans were not a major consideration. This was acknowledged in the memorandum thus: "This work should properly be very largely entrusted to Africans, but at present there are exceedingly few suitably qualified Africans available. ${ }^{, 123}$ Were there really too few Africans who could meet these basic qualifications? The designed compensation and benefits package clearly had the Europeans in mind. The answer lies in the pervasive racial color bar that was indicative of the colonial state. Many of the Europeans who were about to be recruited into this cadre of service also lacked the prerequisite qualifications. There was an agreement by the CO that Nigeria should cast the net as wide as possible and that the development officers recruited should be of a variety of types. The intention was that some of these officers would be absorbed into the administrative service, and the government was willing to provide them the financial assistance they needed in order to obtain the academic qualifications for administrative service. ${ }^{124}$

This was a choice that was not given to the Nigerians. Nigerians with a basic education could have been recruited and trained to obtain the qualifications necessary for service. However, the plan was that the European development officers would teach the Africans the duties of development officers and then eventually hand over responsibilities to them at the end of their ten-year temporary appointment. Given how low the criteria

122 Ibid.

${ }^{123}$ Memorandum on Development Officers in Nigeria, 7 December, 1944, TNA: CO 583/271/4.

${ }^{124}$ Ibid. 
was for those to be appointed development officers, one would think that there were many Africans who were qualified for the positions from the start. The goal was to recruit one hundred development officers and because of the war, they believed it would be hard to find enough people and they wanted 35 people at the beginning of the plan's implementation. It is inconceivable that, in 1945, Nigeria did not have one hundred people or even 35 who were from good backgrounds, intelligent, could take initiative, were honest and were able to follow a single instruction. The job of a development officer did not require any advanced degrees. By the early 1920s, there were many Nigerians who had certificates from colleges and were teaching or engaged in other occupations. The idea of the British officials was also to bring in development officers from the rank of those who had served during the war with the West African troops. The British officials did not see fit to recruit some of the Nigerian troops who had fought alongside the British during the war and demonstrated their patriotism through their willingness to die in battle. Some of these returning troops would have been the most ideal candidates for the job of development officers. Yet, no serious debate or consideration was given to this fact. That the British officials in Nigeria opted for Europeans was not because of the dearth of suitable candidates for the position of development officers in Nigeria. It was, rather, part of a racial ideology that claimed that the African was incapable of the most basic tasks such as following a single instruction. The European, who was probably not as educated or as intelligent as the African, was soon to be given the job in which part of his duties would be to train the African in the most basic tasks which the African could carry out without any education or assistance by the European. 
The systemic racism that was inherent in the colonial state created a paradox for colonial development. While the development plans encompassed some ideas that could have potentially done a lot of good for the colonies, the racial limitations of colonial rule incapacitated these plans and hindered them from becoming successful. By limiting and under-utilizing human capital, the colonial state was invariably undercutting the fundamental key to sustainable development. In light of the historical trajectory at this time, the decolonization movement that was in its early years and Britain's desire to hold onto the colonies, colonial development became a contradiction. The nexus of colonial development was the empowerment of the people in the colonies to realize their full potentials and that the colony be self-supporting. However, if the colonies achieved this potential, there would be no need for the expert services of the colonial state. The question then becomes, is it possible to have colonial development without selfdetermination? It was the attempt to maintain this balance that made the colonial state to limit and restrict the development of the local human resources.

\section{Development and Insufficient Financial Resources}

The meetings and negotiations that were held between the Nigerian officials and the $\mathrm{CO}$ officials were in anticipation of the Cabinet accepting to increase the funds for colonial development. In November of 1944 Colonel Oliver Stanley, the S of S, submitted to the Cabinet a request for a substantial increase of funding for colonial development. Stanley's appeal to the Cabinet was couched in terms of the future of the empire. In his view, the development of the colonies would determine Britain's future in regards to its empire. The colonies did not only contribute substantially to the war but 
they were now needed to help Britain's economic recovery. This was the wrong time for Britain to give up the colonies. The only way that Britain could sustain its empire was to carry out the work of social and economic development. Stanley argued that the war had two effects on colonial policy: "on the one hand it increased our awareness of past deficiencies in our administration,' whilst on the other hand it greatly raised the aspirations of the colonial populations for improved conditions, especially amongst those who, 'in one branch or another of the Armed Services, have been enjoying a standard of living to which they have never been accustomed before [and] have travelled thousands of miles from their villages." ${ }^{125}$ The Nigerian soldiers that were returning from the war were going to face deplorable social conditions back home. Before the war, development work had been mostly neglected in Nigeria and it was necessary that substantial investments be made for the development of the colony. For example, during the economic depression of the 1930s, the small numbers of staff were further cut and services had been so reduced that they were "more or less care and maintenance basis, with the result that development even at the slow pace which had become customary in colonies was practically eliminated." ${ }^{126}$ The second problem Stanley anticipated was one that would play out in India in a major way. Most of the soldiers who had served in the war returned home to the same conditions they had left and having enjoyed a better standard of living in Europe while in service started agitating for freedom from British rule. As Yasmin Khan writes, "Troops housed in one camp twenty miles from Delhi, 'had

\footnotetext{
125 Havinden and Meredith, Colonialism and Development, 226.

126 Notes of a discussion with the Treasury, 9 November 1944, TNA: CO 583/271/4.
} 
become accustomed to a new standard of living in Germany....some had the conviction that they were coming to a free India' and others wrote to the newspapers." ${ }^{.127}$

Stanley's proposal for extensive development in the colonies had a dual function: the improvement of the lives of the colonial people and the maintenance of the empire. To achieve this, he requested $£ 150$ million and an extension of the Colonial Development and Welfare Act for another ten years, the period from 1946 to 1956. Given the economic hardship that Britain was experiencing, the chancellor of exchequer would only agree on $£ 10$ million a year, plus an additional $£ 1$ million a year for research, making the total sum $£ 110$ million over ten years. Stanley argued that the colonies were worth the investment and that Britain would benefit either directly or indirectly from colonial development in the form of exports. He believed that Britain needed the Commonwealth and Empire if it hoped to play a major role in world affairs. Winston Churchill, who was the Prime Minister, agreed with the chancellor of exchequer and the Cabinet decided that Stanley and the chancellor would have to work out a compromise. In December of 1944, they reached a compromise of a total sum of $£ 120$ million over ten years with a maximum of $£ 17.5$ million to be used in any one year. ${ }^{128}$ As Havinden and Meredith argue, there was no rationale for Stanley requesting $£ 150$ million or accepting $£ 120$ million. Given the economic circumstances Britain was in, these figures to the $\mathrm{CO}$ seemed like what Cabinet would be willing to approve. ${ }^{129}$

127 Yasmin Khan, The Great Partition: The Making of India and Pakistan (New Haven: Yale University Press, 2007), 13.

${ }^{128}$ Havinden and Meredith, Colonialism and Development, 227-28.

129 Ibid., 229. 
If Stanley wanted to carry out a strategic policy of social and economic development of the colonies, as he seemed to portray in his statements, asking for $£ 150$ million and accepting $£ 120$ million even before the needs of the colonies were clearly laid out was akin to putting the cart before the horse. The most sensible approach would have been to let the colonies draw up their plans within broad financial guidelines and the $\mathrm{CO}$ would study these plans, restructure them, cost them and then make a request to the Cabinet for the money needed to execute the plans. The CO was requesting for only $£ 150$ million for the development of the colonies when the Nigerian plan alone amounted to $£ 55$ million. At the end, Nigeria received the $£ 23$ million from the fund, but that was insufficient compared to the social and economic needs of the colony. Due to limited financial resources, development was concentrated mostly in the urban areas. The rural areas were only marginally touched. The plan did not invest heavily in capital intensive projects such as building a nationwide electricity grid. For example, for the first five years of the plan, only $£ 355,000$ was earmarked for electricity. If you fast forward to the 1962 plan, Kainji Dam electrical project alone received an allocation of $£ 68.1$ million. This one project was higher than the total cost of the 1945 development plan. Thus, in addition to the racial biases and limitations of the colonial state, insufficient financial resources were a major bottleneck to the success of this plan.

\section{Bureaucratic Structures and the Exclusion of Africans}

The agreement on the amount dedicated to colonial development by the Cabinet paved the way toward the passage of the act by the parliament. The act was passed by parliament in April of 1945. With the passage of this Act, the different British colonies 
were now asked to submit Ten-Year Development Plans. This was the first time there was a more systematic long term planning on the development of the colonies. Nigeria was way ahead of the other colonies in the drafting of its plan. In late 1944, it was agreed that there was no need for the creation of a statutory development board in Nigeria. However, on $6^{\text {th }}$ March 1945, Governor Richards sent a letter to the S of S informing him that he had set up a new bureaucratic agency, called the Central Development Board. This board had the responsibility to consider, coordinate and recommend all development projects to the government. He wrote, "Its main function will be to deal with overall development and to be the clearing house for recommendations coming forward from the Provincial Development Committees through the three Area Development Advisory Committees in order to ensure that a reasonable series of priorities should be set up for the whole of the territory.",130

Richards' proposal for a development board was one that met with some criticisms in London. D.J. Parkinson at the CO wrote a memorandum on March 13, 1945 in which he disagreed with the arguments advanced by Richards for the new board. In his proposal, Richards explained that he used the title of "Board" for his new central organization rather than the title of committee to distinguish this organization from the area and provincial committees and also because of the function this group would play. Parkinson disagreed with this reasoning. He wrote, "it appears from the explanation of the Board's functions, as described in the saving telegram, that they bear practically the same relation to the Area Development Committees as the functions of the latter do to the

\footnotetext{
${ }^{130}$ Richards to Stanley, 6 March 1945, TNA: CO 583/271/4.
} 
Provincial Committees; and if the central organisation is in fact the topmost of a hierarchy of committees, the introduction of a new name would seem more confusing than otherwise." 131 The function of the new board was not different from that played by the area development committees. It would have been more appropriate to retain the title of committee since people were already familiar with the role played by the area development committees. The governor was attempting to grant this new organization the kind of authority that the committees did not have.

Parkinson's case against this new board was not at all altruistic. He argued that by publicizing the names of this new board, there would be an immediate demand for African unofficial representation. Membership on this board, as envisioned by the governor, was not to include Africans. The governor's reasoning was that there were no Africans capable of viewing Nigerian interests as a whole. This argument was an insult to the Africans because it reduced them to tribalists who could not think in their own national interest. This argument would prove itself erroneous when later on the different regions of the country came together and fought to end colonial rule in Nigeria. Parkinson was not convinced of the governor's rationale for excluding the Africans. While he conceded that the argument might be true, it was not sellable for several reasons. First, two Nigerians were already on the Executive Council of Nigeria, on whose advice the governor legislated for Northern Nigeria. The second reason this may not convince Africans was because supplemental expenditures in excess of the ordinary estimates had to be passed by the Finance Committee of the Legislative Council that had

${ }^{131}$ Memorandum by D. J. Parkinson, 14 March 1945, TNA: CO 583/ 271/4. 
African representation. He argued, "if it is possible to arrange for the unofficial element in the Legislature to exercise control over the ordinary expenditure of the colony, it should also be possible to arrange for the Legislature to exercise control over development expenditure, which in the future is going to form a very considerable portion of the colony's budget." ${ }^{, 132}$ Since the governor had already publicized the names of the members of the board in connection with the statement on development, Parkinson thought the damage had already been done but left open the possibility of further discussion with the governor when he returned to London in the summer of 1945. This memorandum was shared with O.G.R. Williams, Gerald Creasy, Sydney Caine and J.B. Williams. O.G.R. Williams agreed with Parkinson that the damage was already done and there was not much more to discuss. The others agreed also with him, and the board stood as conceived by the governor. ${ }^{133}$ This is a case in which the governor arm-twisted the CO to follow his bidding. By publishing the names of the board ahead of any consultation with them, he forced them to accept his decision.

The creation of this new board ushered in a new bureaucratic structure, one that was different from the structure in place since 1943. There was no longer a central advisory committee. This committee was replaced by the area development advisory committees. There were three of these committees and their task was to screen the recommendations made by the provincial committees and to advise the chief commissioners. The three committees were located in the three regions of the country: the Western Region, the South-Eastern Region and the Northern Region. Governor

\footnotetext{
${ }^{132}$ Ibid.

133 Ibid.
} 
Richards created the central development board, which was not much different from the central advisory committee. The only difference was that Africans were excluded as members of this committee, although the governor offered a different rationale. The reason he gave for omitting Africans was that it would be difficult for the central advisory committee to have regular meetings given that African representatives from all parts of the country would be represented. It would take time for them to travel and be present at these meetings. For the governor, this would render the work of the committee ineffective because the committee may not have to meet as regularly as it should. Parkinson disagreed with this reasoning. He said, "I do not see that it should be any more difficult for an African unofficial to get down to Lagos than for the Chief Commissioner."134

Given that there was now one central development board that had the authority to determine which development projects received funding and which ones were rejected, it is worth asking who were the members who made up this new board? This board had the development secretary as the chairman, the three chief commissioners of development, the financial secretary and the director of public works. None of the six members of this powerful board was a Nigerian. As stated earlier, the governor's reasoning for excluding Africans from this board was the difficulty of choosing Africans that could represent the interest of the different parts of the country. In order to do that, it would mean Africans from the Northern region would also have to be appointed to the board and because of the distance, it would be difficult to summon them to meetings at short notice. The solution

\footnotetext{
${ }^{134}$ Ibid.
} 
he proffered to address the question of African participation in the development planning was to increase their presence at both the provincial level and district level. At this time, the total membership of the provincial development committees was 467 and of these, only 80 were Nigerians, who were non-official members. The reason for the small number of Nigerian members was due to the fact that the committees were made up mainly of official members and there were no senior African officials. Official members were chosen because of "the necessity for having the technical advice which only these Government officers are able to provide."135

The argument for a few African members in the provincial development committees is not a convincing one. By 1945, there were numerous Africans who had acquired education in Europe and America and had returned to Nigeria. Examples were men like Nnamdi Azikiwe who studied in the United States and returned to Nigeria in the early 30s and was newspaper publisher and Herbert Macauley who had studied civil engineering in England in the 1890s and had a brief stint working for the colonial state in Lagos. The growing distaste of these two men with colonial rule and its exploitation of Africans forced them to cofound the National Council of Nigeria and the Cameroons, a nationalist movement that fought for Nigeria's independence. Besides these western educated elites, there were some Africans that were locally trained in different technical skills and were also trained as teachers. A broad section of the African populace could have been engaged in these development committees in order for them to represent the interest of the local people. That the Africans were not involved in larger numbers on

\footnotetext{
${ }^{135}$ Ibid.
} 
these committees shows how deeply engrained still was the colonial ideology of European superiority. The lack of presence of Nigerians both on the area development committees and on the central development board shows that despite Governor Richards rhetoric that he was interested in more Nigerians being actively part of the development planning, he did not want them to be able to make majority decisions on the projects that they felt would be more beneficial to them. One may erroneously argue that the colonial state should have made the determination on the projects since they were administering and paying for them. This argument is not plausible because the projects were not a handout from a generous "mother nation" to Nigeria. A substantial part of the projects was paid for with Nigeria's money and the loans that were subscribed for the projects were collected in Nigeria’s name. Between £10-11 million was to be contributed to development from Nigeria’s revenues and £16-17 million borrowed by Nigeria. The $\mathrm{CD} \& \mathrm{~W}$ fund was to account for $£ 25$ million of the expenditures for development. Given that Nigeria was paying for a substantial part of the projects, a cross-section of Nigerian people ranging from the western educated elites to teachers and peasant farmers should have been given more seats in the development table to determine what projects they may find the most beneficial to them. This point cannot be overemphasized because it is a problem that continues to plague development planning both in Nigeria and other subSaharan African nations. Usually, it is the foreign nation that determines what projects it believes the country needs in order to improve living conditions and the economy. These projects usually require the recipient country to provide a percentage of the cost of the project. In this way the country was made to pay for projects that were not of immediate priority to it. Today, remnants of equipment can be found throughout rural Nigeria from 
the many abandoned schemes that were imposed upon the local people by outsiders who believed the schemes were going to bring about development in these rural communities.

\section{Approval and Funding of the Plan: Caine Vs. Nigeria}

The Nigerian colonial bureaucracy set up by Governor Richards prepared the plan that was submitted to London. In the initial discussions with the $\mathrm{CO}$ on the Nigerian plan, the focus was on getting approval for the different projects that would become part of the plan and also getting approval for the general framework of the Nigerian plan. It is important to note that at this time, there was no single document that contained the whole plan of development for Nigeria with all the different projects. There were several plans that dealt with different departments such as health, agriculture, forestry, veterinary services, roads, and so on. In July of 1945, the Nigerian plan received a general approval from the CO. The letter of approval read, "We are in general agreement with the main outlines of the revised plan, which provides for a total expenditure over the ten years ending March, 1956, of about $£ 56$ million, of which total it is proposed that sums of the order of $£ 16$ million should be found from Nigerian revenues, $£ 17$ million from the proceeds of public loans, and $£ 25$ million from grants and loans under the Colonial Development and Welfare vote." 136

Though a general approval was given, due to the requirements of the CD\&W Act, Nigeria still had to send to the $\mathrm{CO}$ for approval schemes that had received prior approval for shorter periods and that now had to be extended for the ten-year period. Such schemes from Nigeria fell under the plans for agriculture, veterinary, health, forestry and roads.

\footnotetext{
${ }^{136}$ Creasy to Smith. 6 July 1945, TNA: CO 583/271/4.
} 
The governor and the development secretary wanted to present the Nigerian plans to the Nigerian Legislative Council in November of 1945. They wanted to present the different plans in installments as "Sessional Papers" because they felt that waiting to present one large volume containing all the different schemes might be indigestible to the members. Since the plans had between 20 and 25 major schemes in them, their strategy was to issue two or three plans confidentially each week. Smith was seeking for approval of the pending major schemes and also permission to release the plans in installments. ${ }^{137}$ The request to submit the schemes in installments was agreed by the officials at the CO. A telegram was sent to Smith saying, "We entirely agree that descriptions of approved schemes may be communicated to members of Legislative Council as they are ready and not be kept back till full development plan has been finalised. We should be glad to have up to 6 copies of each sessional paper as these are issued." 138 While Smith was given the approval to present the plans as sessional papers, what he did not receive was approval for the major schemes. Meanwhile, Governor Richards was on leave and G. C. Winteley was appointed as the officer administering the government. In September, Winteley sent a telegram to the $\mathrm{CO}$ requesting for the approval of all the schemes because they could not draft the full ten-year plan without first having the approval of the schemes. His argument was that the members needed to receive the full plan with the total financial implications by the first week of November at the latest, if the members were not to accuse the government of stampeding the council with financial issues. ${ }^{139}$

\footnotetext{
${ }^{137}$ Smith to Creasy. 10 August 1945, TNA: CO 583/271/4.

${ }^{138}$ Creasy to Smith, telegram, 28 August 1945, TNA: CO 583/271/4.

${ }^{139}$ Winteley to George Hall (S of S), telegram, 20 September 1945, TNA: CO 583/271/4.
} 
In a meeting held on 24 September 1945 at the CO, the outstanding applications for health, agriculture, forestry, veterinary service and roads were discussed at the request of Winteley and Smith from Nigeria to have the schemes approved. Several points were raised during the meeting. The applications that were submitted by Nigeria did not have identifiable schemes. It was felt that by approving these applications, the $\mathrm{CO}$ was signing away very large grants to Nigeria, creating a later difficulty of identifying which services the money was being used for. The members present at the meeting felt that it was more preferable to have grants go to specific projects. The five applications sought for a grant of $£ 7.5$ million over ten years. In the agricultural application, for example, $£ 750,000$ was allocated to "other charges." Members present at the meeting had concerns about this. Another issue raised was the payment of European staff by the CD\&W grants and the payment of African staff by Nigeria. At the end of the ten-year period, that was going to create a problem when, suddenly, the Nigerian government would assume the payment of these European staff. That would place severe stress on the Nigerian budget. Caine's opinion at the meeting was that $\mathrm{CD} \& \mathrm{~W}$ grants toward the expansion of staff should be given in the form of a percentage. The Nigerian budget assumes a percentage of the cost while the $\mathrm{CD} \& \mathrm{~W}$ grants assume the other part. Over the years, CD\&W's grant percentage would be gradually reduced so that by the end of the ten year period, Nigeria was paying for the entirety of the staff. In this way, the Nigerian budget would not suddenly be hit by a heavy recurrent expenditure for staff. This procedure had already been followed in a scheme that had been approved for Jamaica. ${ }^{140} \mathrm{~A}$ draft letter was prepared to be sent to Smith informing him that the schemes would be framed on a

\footnotetext{
${ }^{140}$ Notes of a meeting at Frank Stockdale's room, 24 September 1945, TNA: CO 583/271/4.
} 
percentage basis. The draft letter was first to be approved by others present at the meeting and also shared with the Treasury for their views. ${ }^{141}$

Meanwhile, Governor Richards had returned to Nigeria and he sent a telegram to the CO reiterating the urgency in approving the outstanding schemes. He wrote, "Unless outstanding schemes can be disposed of at once, so that writing of draft full plan can proceed immediately, there will be insufficient time for this draft to be sent to you for approval and to be put in print by the first week in November, which I consider to be the latest date for the circulation to members if the Legislative Council is to meet on 10th December." $" 142$

What neither the governor nor the development secretary were aware of was the fact that there were discussions in the $\mathrm{CO}$ as late as September about changing the procedure for funding the Nigerian plan. Given that Richards and Smith had discussed extensively with the $\mathrm{CO}$ and had even revised the plans according to their requests, he was anxiously expecting an approval so that he could present the plans before the Legislative Council. The proposal on awarding the grant on a gradual percentage basis was changing everything late in the game. Parkinson was very critical of this decision. He felt that there wasn't enough time for Mr. Smith to recast and re-submit five of his most important schemes. He had only one month before the date he was supposed to present them to the members of the Legislative Council. He also argued that the agricultural plan that drew much of the criticisms was first submitted on the $27^{\text {th }}$ of June 1944 and was fully discussed with the $\mathrm{CO}$ agricultural adviser. After further discussions with the

141 Ibid.

${ }^{142}$ Richards to Hall, telegram, 9 October 1945, TNA: CO 583/271/4. 
development department at the $\mathrm{CO}$ and also the Treasury, it was revised and resubmitted in July. The same was true of the forestry plan which was revised and re-submitted on 13 of July 1944 and the medical plan that was also revised and re-submitted. Parkinson felt that Smith was expecting an approval with only minor modifications. Sending the draft letter radically changing the way grants were going to be given for the development plans was going to come to him as a rude shock. Parkinson found the arguments for funding on a graduated percentage basis unconvincing. He pointed to the earlier approval of development officers and preliminary expenditure on medical and health services which had provided for an expansion of staff with funds entirely from the CD\&W grants without any objections. He also did not see any practical advantages for the graduated percentage as the agricultural plan, for example, only called for a steady expansion of staff combined with proportionate increase of expenditure on other charges. Parkinson wrote,

We do not object either to the total expenditure proposed for agriculture, or to the total amount to be provided from C.D. and W. schemes, or to the object on which the money is to be spent. ... Our objection is to the way in which it is proposed to apply the C.D. and W. assistance. But even if the whole of the expenditure was met from C. D. and W. Funds in the early years, the money thereby saved to Nigeria would only have to be devoted to meeting the increasing deficit in the later years, as the C. D. and W. assistance tapers off, and at the end of the ten year period Nigeria would presumably be in exactly the same position financially as if the assistance had been provided as originally proposed. $^{143}$

Parkinson recommended that Nigeria must be clearly advised on what they needed to do and the advantages of the new proposal.

\footnotetext{
${ }^{143}$ Minute by Parkinson, 1 October 1945, TNA: CO 583/271/4.
} 
Sir George Gater, while not disputing the wisdom of the new proposal, agreed with Parkinson's view that the new proposal was going to be a shock to Smith and may evoke a tremendous outburst from both Smith and the governor. Like Parkinson, he argued that the agricultural scheme was discussed with the agricultural adviser, Dr. Tempany, and revised to his approval and full support. It was also discussed with the representatives of both the Finance and Development Department and the Treasury and no objections were raised. Given the process this went through, Smith would have grounds for complaint. His suggestion was that the Nigerian plan should be accepted as it stood with provisions for some additional safeguards as regards expenditures of money from the CD\&W fund. ${ }^{144}$ On 11 October 1945 , the $\mathrm{S}$ of $\mathrm{S}$ sent a letter to Governor Richards granting approval for the basic proposals for the outstanding schemes. He, however, informed him that modifications have been made to the precise form in which the assistance was to be given and also that there would be variations in the distribution of the funds between different services and over different years. Caine was to communicate the details of these modifications to Smith. ${ }^{145}$

On the $10^{\text {th }}$ of October 1945, Caine sent a letter to Smith informing him in detail of the procedural changes that were to be adopted in regards to the Nigerian plans. His letter anticipated the reaction that might come from Smith. From the outset, he informed Smith that although they had talked about the development plans before, they had to take another careful look at the applications. The reason for this, he wrote, was because of the magnitude of Nigeria's development plans in relation to those of the other colonies.

\footnotetext{
${ }^{144}$ Minute by Gater. 3 October 1945, TNA: CO 583/271/4.

${ }^{145}$ Hall to Richards, 11 October 1945, TNA: CO 583/271/4.
} 
Given the scale of Nigeria's plans, it was only prudent that the details of the schemes should be looked at carefully. Two major applications that Caine picked on were agriculture and forestry. These two had something in common. In both these areas, all the grants requested from the CD\&W funds were for emoluments and recurrent charges in connection to the expansion of staff. While Caine believed that the funds requested for these applications were acceptable, he did not think that the method proposed for the use of these funds was the right one. He found two main difficulties with this. The first was that this amounted to handing a blank check to Nigeria, and this would not be a fulfillment of their responsibility to Parliament. The second difficulty he had was with Nigeria suddenly assuming these financial responsibilities at the end of the ten years when CD\&W grants would have run out. He believed that this would create great difficulties then. To resolve these two difficulties, Caine suggested two solutions:

The first is that C.D. \& W. grants towards recurrent charges in these two applications (agriculture and forestry) ought, as far as practicable taper off towards the end of the ten year period, so that the transference of the residual is less burdensome. (This need not affect the total assistance, but only its distribution in time). The second is that the C. D. \& W. assistance might be given not to cover the full cost of the salaries and incidental charges for certain classes of new employees, but to cover a proportion, of the cost of all the new staff required for the development of these departments. ${ }^{146}$

Caine went on to suggest to Smith that these two schemes, together with all new applications for grants that involve the expansion of staff be amended so that the grants would only go toward a percentage of the staff salary while the rest would be assumed by the colonial state. The percentage should be graduated over the ten years period with it peaking in the middle years and then beginning to drop toward the tenth year. At the end

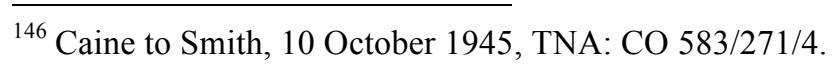


of the tenth year, Nigerian revenues should be paying fully for the staff. The amount of assistance agreed with Smith was not changing, what was changing was the procedure on how this assistance was going to be given.

While Caine's argument may sound logical, what it did not take into consideration was the economic power that came from investing such large sums in agricultural development at the initial period. Caine's main issue was distinguishing between "productive" and "recurrent" costs. He did not think that CD\&W funds should pay for recurrent costs, because this was unsustainable and thus would create dependency on London. He wanted the colonial state to cover such costs. The colonial government was not attempting to shift recurrent costs to London. It wanted to front load resources and build up its agricultural extension services and hire colonial personnel to help stimulate agricultural production and generate the revenues that would be needed by the state to continue and expand development for many years. Expanding agricultural staff was a pathway to expanding agricultural production. At this time, the main revenue of Nigeria came from agricultural production. Unlike many other colonial regions, Nigeria did not have large-scale industrial agricultural production. It was mainly peasant agriculture. This system, by its very nature, required plenty of agricultural staff if production was to increase. This is because you need extension staff who would train the rural people on how to expand production through the use of fertilizers, improved varieties and irrigation. What Nigeria was trying to do was to front load resources. The expansion of staff had the potential to expand production which would have placed Nigeria at a better economic position to absorb the staff at the end of the tenth year 
without placing undue burden on Nigeria's budget. This was one of the strengths of this plan.

\section{African Agency}

Though Africans were not well represented in the decision making process with regards to this development plan, they still shaped this plan through the pressure that they exerted on the colonial state. Smith responded to Caine five days later, arguing that radical changes to the way assistance is to be provided would create difficulties. He wrote, "We have gone on the principle of maximum assistance in the earlier stages, expecting that taxability of the people would increase as the plan develops. ${ }^{\not 147}$ The expansion of production by the peasants meant more revenue from the government through taxes. Nigeria was not then in a financial position to provide the kind of assistance that Caine was requiring of them. By adopting Caine's position, Nigeria had to borrow more money because it could not further tax the people. To borrow more money, she would have to look to London and, because of the post-war economic crisis and the pressure on the Sterling, it was highly discouraged to borrow in London. Smith stated that he faced a political problem, which Caine may not have understood. He had to deal with the African unofficial members of the Legislative Council as well as the African press that was very critical of the moves made by the colonial government. In his letter to Caine, Smith informed him of some of the local political factors he had to deal with. He wrote:

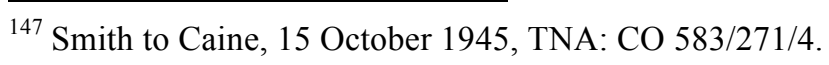


the local press is already stating that the development plan is merely a means of manipulated use for money intended for the benefit of Dependencies to find jobs for more Europeans. As in the early stages, we shall have to use many Europeans to implement the plan until the training of Africans has been suitably increased, you will appreciate the difficulties I shall have in introducing the plan and getting it passed if we have to deal in vague terms. In fact, we may very easily lose the present confidence of the Council completely in such circumstances, as Unofficial Members will be heavily bombarded by the press on the racial aspects, which are now becoming very pronounced. ${ }^{148}$

It was in the interest of the Nigerian colonial state to be seen rapidly developing the colony. There is no doubt post-war development was a genuine attempt to develop the colonies, though not completely altruistic. At this time, it was even difficult to find technical officers such as irrigation engineers, from Britain. The colonial officials were looking to find technical officers and development officers from Canada. What is also true is that Africans were not given the opportunity to receive the kind of training that they needed to assume the positions that they were now attempting to fill. Though Africans were not involved in the negotiations between the $\mathrm{CO}$ and the colonial state, their opinions were taken into consideration and the state had to appear to be acting in the interest of Africa. Africans trained at the Yaba College of Technology were provided a secondary education that did not qualify them to assume these special opportunities. That was an opportunity that was missed. The racial undertones in the press were a reaction to the many years of colonial rule in which Africans were not given an opportunity to take leadership in their own destiny. Nigerians agitated for more control through trade unionism and the national press such as the West African Pilot. The Trade Union Congress of Nigeria (TUC) founded in 1943 published a quarterly bulletin called The Nigerian Worker, and it demanded for the representation of labor unions in the

\footnotetext{
148 Ibid.
} 
Legislative Council. In an attempt to capture the plight of the Nigerian worker and convert it to positive action, the TUC called for a general strike in 1945.

This strike, which had a strong support from the NCNC linked the nationalists struggle with the labor movement. ${ }^{149}$ The strike created grave doubts in many Nigerians if the intentions behind its economic plans were well-meaning. Falola states that many "derided the Ten-Year Plan as a bourgeois document... The plan was interpreted as a design to exploit Nigerians, an afterthought to justify the transfer of wealth out of the country, and admission of guilt that the people had been cheated. In their own campaigns for attention, the politicians among the intelligentsia warned the masses not to expect any positive outcome from the plan." 150 This was the reality that Smith and Richards faced in Nigeria. The trade unions and the nationalist movements such as the NCNC, the Nigerian Youth Movement and the Zikist movement were becoming more involved in the public sphere and while they embraced the idea of development, they tried to use it to demand for rights. ${ }^{151}$ As one Nigerian, J. K. Ladipo, the managing director of a mill at the time, wrote to the Chief Secretary of Government (CSG): "In the days of our forefathers the farmer was the life of the country, to-day he is a poor man, and the clerk, who draws his salary from his sweat, is the richer and better man comparatively speaking. And yet often times you have the courage to ask us to 'go back to the land'. Undoubtedly in order to become poor. ... as far as I can see it is no business of the Secretariat if Nigeria is in debt,

149 Robin Cohen, Labour and Politics in Nigeria (London: Heinemann, 1974), 172-73.

${ }^{150}$ Falola, Development Planning and Decolonization in Nigeria, 70.

${ }^{151}$ Cooper argues that Africans took the assertions of the colonial rulers and turned them "into claims and mobilizing ideologies of their own." See, Cooper, Africa Since 1940, 15-16. 
as long as the officials can be paid out of loans from the outside world and they can retire when the time is due leaving us, the Nigerians to foot the bills afterwards."152

This was the sense of frustration that the Africans felt and the one the Nigerian officials had to deal with. Flooding Nigeria with so-called experts that were going to be paid with Nigerian revenues or loans borrowed in the name of the government of the colony was a hard sale. The British government committing the money ahead to pay for the expansion of staff would show their commitment to developing the colony. It also would quell the criticism that development in the colony was only a jobs program for Europeans paid for with Nigerian revenues. This is because Nigerian tax payers would be footing the bill. Smith concluded his letter to Caine in very strong terms. He wrote, "In these circumstances, and after all the discussions which have taken place, I trust that you will not show such lack of confidence in local administration of development as to remove local discretion, which is essential to its satisfactory and proper implementation. Any vagueness on your part will be a serious hindrance, and it is obvious that we shall have to take the Council and Local Administrations fully into our confidence to get the plan approved and to ensure that it is properly put into effect." 153

Caine responded assuring Smith that there was no lack of confidence in the local administration. London's concern was not to tie Nigeria down on a very rigid plan of development when they cannot foresee future circumstances. He offered Smith language to present to the Legislative Council. He wrote, "Indeed, I think it might help in presentation to council if you took the line that Government is not asking the Legislature

152 J. K. Ladipo to CSG, 10 December, 1945, RH: MSS. Afr. S. 2124.

${ }^{153}$ Smith to Caine, 15 October, 1945, TNA: CO 583/271/4. 
to commit itself at once to all details over a long period ahead but is submitting a general plan on which the Council can give a broad approval now while leaving scope for all concerned, including the Council itself, to suggest modifications as parts of the plan come up for approval in precise form." ${ }^{154}$ Caine's plan was not more flexible than the Nigerian plan. In fact, the Nigerian plan was more flexible. The biggest problem Caine had was that by approving the Nigerian plans without having the details of expenditures for every scheme, it amounted to giving Nigeria a blank check. The officials in Nigeria, on the other hand, wanted the flexibility by not tying themselves to too much specifics on the expenditures of the schemes. Caine was undercutting his own argument by claiming flexibility. At the heart of this was a dispute on who controls the development planning process. This was basically a struggle between the colonial state and the CO.

\section{The Rift Between Colonial Office and Nigeria}

The disagreement between Caine and Smith opened a rift between the $\mathrm{CO}$ and Nigeria. This was not surprising as some in the $\mathrm{CO}$ had warned that Smith and Richards may not take the changes kindly. In light of the correspondences between Caine and Smith, Richards decided to hold off releasing the plan to the Legislative Council until he was able to reach an agreement with Caine. He offered some revisions to the Nigerian plan to meet the demands of Caine. For example, in the last four years of the plan, the $\mathrm{CD} \& \mathrm{~W}$ vote would only provide for $4 / 5,3 / 5,2 / 5$ and $1 / 5$ of the recurrent charges in agriculture, veterinary, forestry and health schemes. The governor, however, raised an important problem that may arise with regards to staff. The fear was that he might have a

\footnotetext{
${ }^{154}$ Caine to Smith, 17 October 1945, TNA: CO 583/271/4.
} 
problem engaging good staff for only a short term. He needed assurance from the S of S that assistance would continue beyond five years so that staff would be aware of reasonable prospects for ten years employment. Another area of much difficulty was in the recruitment of engineers. Given the scarcity of engineers, it was important to enter into as long as possible agreements with them. Governor Richards then demanded approval of his requests. ${ }^{155}$

In the $\mathrm{CO}$, there were discussions about the Nigerian plans and J. B. Williams even wondered if Richards' conception of development planning was the same as that of the $\mathrm{CO} . \mathrm{He}$ disagreed with the approach Nigeria was taking as regards to their applications. He was critical of the governor's conception of development planning. He wrote, "Our own conception has been that colonies should draw up a broad overall plan of development which should be considered by the Secretary of State's advisers and approved with or without modifications and then detailed schemes covering particular pieces or work should be submitted within the plan and approved separately. ${ }^{" 156}$ The governor and Smith had a different conception. Though they had received a general approval for a comprehensive plan from Nigeria, what the governor wanted to do was to place individual schemes before the Legislative Council. This was where the disagreement lay. In Williams' view, individual schemes with their expenditures still had to be approved by the $\mathrm{CO}$, but the governor wanted a blanket approval covering the schemes for which the expenditures had not been discussed and approved by the CO. Williams found it inappropriate to grant the governor approval to spend $£ 23$ million in

\footnotetext{
${ }^{155}$ Richards to Hall, 23 October 1945, TNA: CO 583/271/4.

${ }^{156}$ Minute by J. B. Williams, 2 November 1945, TNA: CO 583/271/4.
} 
ten years without showing the specific schemes and their costing. This meant that neither the governor nor the development secretary would need any more authority from either the $\mathrm{S}$ of $\mathrm{S}$ or the Legislative Council to spend the money for the next ten years. He doubted if this procedure of giving the governor unfettered access to Nigeria's allocation was in accordance with the conditions that were laid down by the CD\&W Act. That act, he wrote, "lays down that the authority for expenditure is that the Secretary of State should make schemes with the concurrence of the Lords Commissioners of the Treasury."157

Williams also responded to both the criticism of Parkinson and Gater that these schemes had been discussed and revised with the governor and Smith. He wrote, "The understanding in my mind then was that we were being asked to approve merely the comprehensive plan as a whole and that individual schemes could be gone into on their merits and if necessary remodeled, nor was it clear that there was any particular urgency to approve schemes covering the whole of the ten years. It was certainly not clear to me at that time that the Nigerian Government wished to lay schemes in cut and dried form before the Legislative Council." 158 While being sympathetic with the views raised by Williams, Caine believed that not giving an approval in principle to the Nigerian plan meant going back on their word. He disagreed with Williams that the procedure to be followed by Nigeria would be outside of the scope of the Act. Another important point made by Caine was that they were still experimenting with planning. He wrote, "we must recognize that we are still feeling our way towards the kind of procedure which will

\footnotetext{
${ }^{157}$ Ibid.

${ }^{158}$ Ibid.
} 
enable due account to be taken of long-term planning without holding off all action until the ideal plan is produced, which may take years." ${ }^{159}$ Frank Stockdale ${ }^{160}$ agreed with Caine that the Nigerian plans had gone too far to attempt to begin a new procedure. ${ }^{161}$ The point raised by Caine about those involved feeling their way toward the appropriate kind of procedure is an important one when looking at development planning in this time period. No one had the crystal ball on how to develop the colonies. Though some form of development had taken place in the empire for years, this was the first attempt at longterm development planning. Those who were fashioning these policies were not themselves experts with many years of experience in development planning. They themselves were learning on the job, attempting to respond to development problems in the colonies.

In the chapter, I have focused on the conversations that went on concerning the Nigerian plans in order to shed light on the process of decision-making. At the end of the day, the individuals involved at the $\mathrm{CO}$ could not decide on how to respond to the governor of Nigeria. In one sense, they wanted to approve in principle the schemes that were already discussed with the governor and the development secretary of Nigeria. On the other, they did not want to give Nigeria authority to spend CD\&W funds on these schemes without detailed examination and approval of such schemes by the $\mathrm{S}$ of $\mathrm{S}$. The $\mathrm{S}$ of $\mathrm{S}$ wanted schemes emanating from the colonies to be fully examined and vetted by London. The approval sought by Nigeria did not allow that because the governor did not have full details on the schemes in question. Sydney Caine's view was that an urgent

\footnotetext{
${ }^{159}$ Minute by Caine, 2 November 1945, TNA: CO 583/271/4.

${ }^{160}$ Stockdale was an adviser on colonial development planning at the CO, 1945-1948.

161 Minute by Stockdale, 2 November 1945, TNA: CO 583/271/4.
} 
meeting needed to be held to resolve the problem. The problem this meeting sought to resolve was whether the previous correspondence with Nigeria constituted a commitment that could not be broken or whether "it is now desired to re-examine the whole position, in which case, of course, a suitable explanation would have to be given to the Governor with the direct authority of the Secretary of State." ${ }^{, 162}$

This meant, the decision was moving from the civil servants to the politicians and there was a new Labour government in power and a new $\mathrm{S}$ of $\mathrm{S}$ that were very supportive of development and wanted it to happen rapidly. At this time, Arthur Creech Jones was the Parliamentary Undersecretary of State for the Colonies and George Henry Hall was the S of S. When Creech Jones discussed the matter with the officials concerned at the $\mathrm{CO}$ and with the $\mathrm{S}$ of $\mathrm{S}$, he came to the conclusion that the previous $\mathrm{S}$ of $\mathrm{S}$, Oliver Stanley, had already made a commitment to Nigeria and the Nigerian plans were drafted based on that commitment. It was the decision that the Nigerian plans should be approved in principle. Based on this, a telegram was to be sent to Nigeria informing the governor that the S of S had approved in principle assistance toward the big schemes in question. He was also to be informed of the CO's flexibility in reviewing the annual estimates of the schemes and modifying them if necessary, based on the circumstances of the time. Creech Jones felt that there was need for adequate technical advice and this was to be emphasized in the telegram to be sent to Nigeria. ${ }^{163}$

As a result, the $\mathrm{S}$ of $\mathrm{S}$ wrote to Governor Richards on 23 November 1945 informing him that he was prepared to approve assistance in principle to the schemes. He

\footnotetext{
${ }^{162}$ Minute by Sydney Caine, 15 November 1945, TNA: CO 583/271/4.

${ }^{163}$ Minute by J. B. Williams, 22 November 1945, TNA: CO 583/ 271/4.
} 
insisted that the approval was based on the condition that annual estimates must be presented and he reserved the authority to review the schemes and modify them if so needed. This, he argued, would allow for flexibility. He wanted Richards to make clear to the Legislative Council the fact that he reserved the right to modify the approved schemes after annual reviews. He also insisted on the importance of using adequate expert advice on all schemes in which experts were not already available. In response to Richards concern about development officers, the S of S said, "The fact that scheme has not been approved for whole period of their service should surely cause no more uncertainty in minds of officers concerned than fact that funds for salaries of ordinary Colonial Government employees are voted annually and not for a whole period of their careers." "164 Agreement was reached between Nigeria and London and the governor was ready to present Nigeria's development plan to the Legislative Council.

On 8 December 1945, Governor Richards sent a confidential letter to the S of S informing him that that he would be placing the Ten Year Plan of Development and Welfare before the Legislative Council on the $12^{\text {th }}$ or $13^{\text {th }}$ of December. Together with his letter were six copies of the plan. The copies of the plan included were meant for distribution to the London press such as the Times. A vote was not intended to be carried by the Legislative Council on the plan. The intention was for a motion to be taken to refer the plan to a select committee that consisted of both unofficial members of the Legislative Council and a few official members that were directly concerned. The select committee had the task of considering the proposals in detail when they sat in January of

\footnotetext{
${ }^{164}$ Hall to Richards, telegram 23 November 1945, TNA: CO 583/271/4.
} 
1946. Together with the plans sent to the S of S was a summary of the plan that was to be distributed to both the local press and the international press. This one page summary mentioned broadly the different schemes that would be carried out in the first paragraph. The second paragraph mentioned that a suggestion had been made that a board be established for the purpose of providing the means of financing approved schemes of local development. The last paragraph discussed the cost of the plan. The plan was estimated at " $£ 55,000,000$, of which $£ 23,000,000$ will be provided under the Colonial Development and Welfare Act, $£ 16,000,000$ to $£ 17,000,000$ will be raised by loans, and the remainder progressively found from Nigerian Revenues."

The plan was presented before the Legislative Council on the 13 December 1945. A resolution was unanimously adopted by the members of the Council thanking His Majesty's Government for the generous contribution of $£ 23,000,000$ for the development of Nigeria. The resolution read, "That this council accords its deep sense of appreciation for the very generous allocation to Nigeria of $£ 23,000,000$ from the money provided under the Colonial Development and Welfare Act and requests that His Excellency the Governor should convey to H.M. Government and the people of the United Kingdom, through the Secretary of State, the (?gratification) and thanks of this Council, as representing the people of Nigeria, for this most generous and important contribution to the development of this country."166

The governor sent the resolution as a telegram immediately to the $\mathrm{S}$ of $\mathrm{S}$. When you study this plan in question in more detail, however, there are three things that are

\footnotetext{
${ }^{165}$ Richards to S of S, 8 December 1945, TNA: CO 583/271/4.

${ }^{166}$ Richards to S of S, telegram, 13 December 1945, TNA: CO 583/271/4.
} 
conspicuously missing from the plan. The plan did not include agriculture, veterinary, forestry and medical schemes. The reason for the absence of these schemes was because they had not received full approval. They had only been approved in principle. The plan only included schemes that had been approved fully by the CO. The reason the plans had not received full approval was because they were not ready. The next chapter will shed light on why the agriculture plan was not ready.

On 24 December 1945, Smith sent to the CO estimates of those schemes that had not received full approval. Of particular interest to this research was the agricultural scheme. The proposal called for the establishment of a 250 -acre experimental farm in Yola, Adamawa province. This farm would be used to test local and introduced crops such as cereals and roots. A small number of animals were also to be kept there for draft purposes. Another experimental farm was to be established in Maidugari. This farm was to be about 300 acres. The goal here was to experiment with dato palms with the view of introducing them in the Bornu province. These two farms were to be the headquarters of "touring Agricultural officers for the districts concerned who will be able to carry out further experimental and expansion work in the outlying area based upon the results obtained on these two farms." ${ }^{167}$ Part of the proposal was also to experiment with livestock such as cattle and poultry.

Some of the agricultural schemes that were to be introduced in the northern region of Nigeria required a good drainage and irrigation system. The problem at this time was

\footnotetext{
${ }^{167}$ Smith to Williams, Memorandum on the estimates for Colonial Development and Welfare Schemes 1946/47 in connection with the extension of Agricultural, Veterinary, forestry, and health services with notes as to the form of latitude requested in connection with expenditure under certain sub-heads, 24 December, 1945, TNA: CO 583/271/4.
} 
finding an irrigation engineer to bring to Nigeria. The proposal called for the appointment of an irrigation engineer with wide experience who would tour Nigeria, training special officers on the extension of irrigation and drainage work. It was proposed that $£ 10,000$ be allocated for this work. This would include the salary and buildings. Given the topography and geography of Nigeria, it is surprising that the plan only called for one irrigation engineer. Any serious agricultural scheme in Nigeria would require a lot of irrigation and drainage work. Nigeria has two seasons: the raining and dry season. During the dry season, the soil becomes very hard as a result of lack of water. In order to plant crops, you have to be able to channel water to the property. During the raining season, some parts of Nigeria are prone to floods. The rivers overflow and wash away the crops. The water around farmlands has to be channeled properly to avoid the farms being flooded. The irrigation engineer that the proposal suggested was not to be brought in on a full time basis. He was to do one or two tours of duty training others. The writers of the proposal were overly optimistic that a few days of an engineer in a location would be enough to train the local officers on all they would need to know about irrigation and drainage. $^{168}$

Though Smith had submitted the estimates to Williams at the CO on the $24^{\text {th }}$ of March, the four plans were not yet officially submitted to the S of S by the governor. On the $31^{\text {st }}$ of December, Governor Richards submitted them officially to the $\mathrm{S}$ of $\mathrm{S}$. He wanted an approval before the estimates were to be presented to the Legislative Council in February of 1946. The estimates only covered the period of $1946 / 1947$. In these

\footnotetext{
${ }^{168}$ Ibid.
} 
estimates, forestry received $£ 18,140$; agriculture $£ 61,040$; veterinary $£ 48,050$ and medical and health services $£ 102,610 .{ }^{169}$ Given the economic importance of agriculture to Nigeria, one would have expected that agriculture would receive the greatest allocation. In a sense, there was a financial bias toward agriculture. Many reasons account for this. Most of agricultural cash crops from Nigeria were not produced on big commercial farms. Peasants cultivated them. In fact, at this time, there were no large colonial agricultural schemes. Most agricultural schemes were mainly for research and experimentation. The second point to consider is also that the CD\&W Act did not only emphasize economic benefits but also the welfare of the people. Medical services at this time remained very scarce and the mortality rates were high. It was important to commit more resources to combat diseases and to provide medical services.

On 25 February 1946, the CO sent a letter to the Treasury including the estimates of the Nigerian plan and informing them of the general approval in principle of the Nigerian plan. ${ }^{170}$ The CO was willing to have further meetings with the Treasury on the plan. Three days letter, the $\mathrm{CO}$ again wrote to the Treasury requesting a general approval of the Nigerian estimates to enable the governor to have this information before the opening of the Legislative Council in Nigeria on $11^{\text {th }}$ March. ${ }^{171}$ The morning of this second letter, Serpell and Marnham had talked briefly about the Nigerian plan as Marnham references the conversation in the letter. Approval in principle was given by the Treasury while it continued throughout 1946 to work with the $\mathrm{CO}$ on modifications to the

\footnotetext{
${ }^{169}$ Richards to S of S, 31 December, 1945, TNA: CO 583/271/4.

170 J. E. Marnham to D. R. Serpell, 25 February, 1946 TNA: C0583/271/4.

171 J. E. Marnham to D. R. Serpell, 28 February, 1946 TNA: C0583/271/4.
} 
Nigerian schemes. ${ }^{172}$ On 9 March 1946, the S of S granted approval of the estimates and informed the governor that he may have to deal with some details later, particularly certain salaries. ${ }^{173}$ Richards did not find any problem with later changes after the Legislative Council had approved estimates. He pledged that these could always be carried out by administrative control of expenditure. ${ }^{174}$

While the estimates presented by Governor Richards were under consideration by the CO, the Nigerian Legislative Council approved the "Ten Year Plan of Development and Welfare for Nigeria" that had been presented to it in December of 1945 and referred to the select committee. This committee met in January and presented their report to the Legislative Council on 7 February 1946 and the council unanimously accepted the report. The resolution read,

Be it resolved: That this council adopts the Report of the Select Committee appointed to consider the Ten-Year Plan of Development and Welfare for Nigeria set out in Sessional Paper No. 24 of 1945 and approved the Plan as amended by the Select Committee and recommends its acceptance as the general development policy of the Government of Nigeria for the next ten years, subject to periodic review of details in the light of experience and the inclusion of such additional schemes as may prove to be necessary as the result of unforeseen circumstances. ${ }^{175}$

The last part of the resolution provided the flexibility that the $\mathrm{S}$ of $\mathrm{S}$ needed in order to make adjustments to the plan. Richards was happy with the fact that all the unofficial members commented on the desirability of the plan. The positive response of the unofficial members was important to the governor because he was afraid these members

172 Serpell to Marnham, 20 March, 1946, TNA: C0583/27/4.

${ }^{173}$ S of S to Richards, 9 March, 1946, TNA: C0583/27/4.

174 Richards to S of S, 13 March, 1946, TNA: C0583/27/4.

175 Richards to S of S, 23 February, 1946, TNA: C0583/271/4. 
would be very critical of the plan and also incite the Nigerian press against the plan. Richards said that throughout the debate every unofficial member took part and they saw the plan as "a thoroughly constructive piece of work and a clear indication of the desire both of His Majesty's Government, through the generous allocation to Nigeria ... to ensure that this country should be developed as rapidly as possible. ${ }^{, 176}$ For Richards, this was a big win and he could not wait to share the Nigerian plan with all the colonial governors.

\section{Conclusion}

By focusing solely on the correspondences and discussions between colonial officials in Nigeria and London, this chapter reveals certain problems with development planning in the late colonial period. The British had an idea that they wanted to develop the colonies but they did not have a coherent plan on how to go about it. They had to rely on a makeshift of ideas that originated from the colonies or the ideas that the colonial officials in London made. After asking the colonies to draw up these plans for a ten-year period, about halfway through the plans, the $\mathrm{CO}$ asked the colonies to revise them to fiveyear plans because it was difficult to plan for a ten-year period. It is easy to look at the failure of these plans and question the intention of the British to truly develop the colonies. My research shows that the 1945 development plan was a genuine attempt to develop the colonies. The failure to rapidly develop Nigeria was not as a result of bad intentions but to three factors in particular. These were ingrained racial ideologies that either consciously or unconsciously manifested themselves in decision making; the two

\footnotetext{
176 Ibid.
} 
different concepts of development between the $\mathrm{CO}$ and the colonial state leading to bureaucratic wrangling; and the lack of financial resources available. As I have shown in this chapter, there is no doubt that the British were not completely altruistic when they embarked on this development agenda. They needed to hold on to the empire and they wanted colonial resources to help them with their economic problems. However, plenty of the schemes that were carried out were geared toward the social benefit of the people. The relative dearth of financial resources that were available in this period also hampered development. Just coming out of the war, Britain was crippled financially and did not have huge financial resources to put into the colonies.

This study also shows that though Nigeria had to put up a substantial amount of its own money for development, they had a limited voice in what schemes and projects were carried out. Though a few Nigerians served as unofficial members in the Legislative Council and in the development committees, they did not have a vote. One only hopes that their ideas during the discussions were considered. The attempt by the European officials in Nigeria to be the custodians of development was in line with the civilizing mission that the colonial officials had. Inherent in that ideology was the notion that Europeans were superior to Africans and their attitude was patronizing toward the Africans. There was the notion of Britain's “trusteeship" over Nigeria. This ideology held that the African could not determine his or her own future. This future had to be created for him or her by the Europeans. The Europeans saw themselves in a trustee role in which they determined both the future and the pace at which Africans would reach that future. The idea here was that, the Europeans knew better what was good for Africans. The 
African had no role in deciding what he felt was good for him. He was not granted the choice between a school and a borehole. If the European felt the borehole was better for the African, he had to accept it. This meant that both the designers and implementers of development were mostly European.

The third problem is the bureaucratic wrangling that existed between the $\mathrm{CO}$ and the colonial state. This slowed the process and caused the plan to be rushed toward the end. Though agriculture was the core economic factor of this plan, it did not receive the attention that it deserved. At the time that the Legislative Council in adopted the plan of development for Nigeria, there was still no complete agriculture plan that had received approval from the CO.

All three continue to exercise interest. This dissertation is interested in agricultural policy because agriculture up until the early 1970s remained the foundation of Nigeria's economic production. The success or failure of the 1945 plan was to a large extent dependent on the success of the agricultural sector. Thus, in the next chapter, I will look at agricultural policy and planning in Nigeria. 


\section{CHAPTER THREE}

\section{Planning Agricultural Development: The Mackiean Policy, 1936-1945}

\section{Introduction}

This chapter focuses specifically on agricultural planning in the period shortly before and after the Second World War. Agriculture was the mainstay of the Nigerian economy and if Nigeria was to successfully fund its own part of the development plan and continue the work of development beyond 1955, it had to have a strong agricultural program. Though agriculture was expected to provide most of the revenues for the ongoing development of the colony beyond the years of the plan, the agriculture sector did not experience any preferential treatment in the planning process. In fact, at the time that the ten-year development plan was presented to the Legislative Council in December of 1945 and its subsequent approval in February of 1946, the agriculture plan with its detailed schemes/projects had not been approved because the $\mathrm{CO}$ was insisting on Nigeria providing detailed allocations for the different agriculture projects and schemes. For example, out of the $£ 1,597,630$ that was estimated for the agriculture plan, $£ 750,000$ was allocated to "Other Charges." This meant the money was not going to any specific scheme or project. The $\mathrm{CO}$ saw this as granting the governor of Nigeria a blank check. The agriculture plan was not ready due to the cautious and conservative approach of the agriculture department in Nigeria and also the dysfunctional relationship that existed between the agriculture department and the political department. 
In this chapter, I argue that agriculture development in Nigeria was clouded by conflicts and contradictions. The Mackiean policy insisted on careful research and field trials before farmers were asked to change their methods. This approach was cautious and conservative and did not radically change the social and political systems that were associated with African farming. The policy attempted to build strong relationships with the local authorities and also to decentralize agricultural development. However, this policy was also fraught with problems. This cautious approach to agriculture development meant that the policy could not respond to colonial agriculture needs in periods when high production was expected. This policy was also blinded by the color line as it failed to incorporate the local knowledge produced by the farmers. The focus was on the agriculture knowledge produced by the department through research and field trials. Indigenous farmers who had better awareness of their environments were excluded from the production of knowledge. The policy was also doomed to be unsuccessful because it was attempting to change the farming system without radically changing the social-political system upon which both peasant agriculture and the colonial state rested.

For the work of development planning to be successful, both arms of the colonial government needed to work well together. This was not the case in Nigeria. There were two visions of development and these centered on power and control. Who had power and control over development policy in the regions or provinces? The political staff such as the Residents who worked with the African authorities saw themselves as the employees of the African authorities and restricted how much access the technical staff had to the local administrations. This chapter chronicles the rocky relationship Mackie 
had with the political department. At the end, the governor moved toward centralization, wrestling power from the director of agriculture and handing it over to political staff who may not have been knowledgeable about agricultural services. I argue that this was detrimental to agriculture development and that this was responsible for Mackie's sudden resignation from the Nigerian service as he was frustrated with a perceived marginalization of the agriculture department by the governor.

\section{The Nature of Colonial Rule in Nigeria}

To understand the relationship between the agriculture department, the administrative department and the native authorities, it is important to discuss the structure of the Nigerian colonial state. The challenge for the technical departments in the 1930s was that they had to work through the political officials assigned to the provinces and districts. They did not have direct access to the local authorities and the Mackiean policy sought to change this, not by radically changing the socio-political order but finding a way of working within this policy. The colonial state structured power in such a way that the colonial officials controlled the local authorities and these African leaders in turn, controlled the people. This was in line with the principle of indirect rule that Governor Frederick Lugard had introduced across the colony after the 1914 amalgamation of the Northern and Southern Protectorates. Indirect rule was created to maintain order and stability, and not change, which was necessary for development. Sir 
Hugh Clifford, the immediate successor of Lugard, argued that it slowed the rate of progress. $^{177}$

Though the central administration which was based in Lagos controlled the different departmental activities after the amalgamation, it was remote to the people it was supposed to govern. ${ }^{178}$ The people's daily experience was with the local authorities. The north and south were administered by lieutenant governors and these reported to the governor-general who reported directly to the S of S. In 1939, the south was divided into nine provinces and ten years later, the north was divided into twelve provinces. Regionalism was instituted in 1939 with the south being divided into West and East Regions and the north forming the third region and these regions remained in place till the independence of Nigeria in $1960 .{ }^{179}$ With the institution of regionalization, each of the three regions had a chief commissioner and these reported to the governor. The different provinces in the regions had a Resident and these reported to the Chief Commissioners. Below the provinces were the districts which had a district officer or DO as they were called. The emir or chief was the political head of a district. It was this bureaucratic structure that Mackie had to deal with in the 1930s.

\section{Captain James Richard Mackie}

No other person had as great an impact on Nigeria's agriculture in late colonialism as Captain James Mackie. He served in the agriculture department of Nigeria for 24 years before he retired in February of 1945. After a career in the military and at

177 Hodge, Triumph of the Expert, 85.

178 Toyin Falola, The History of Nigeria (Westport, Ct: Greenwood Press, 1999), 16.

179 Ibid., 68-69. 
Reading University, he was appointed as Superintendent of Agriculture on the $7^{\text {th }}$ of September 1921. His first post in Nigeria was at Moor Plantation. The Director of Agriculture at the time was O. T. Faulkner. In order for him to gain varied experience of the agricultural conditions in Nigeria, Mackie was later assigned to Ilorin, which is in Western Nigeria, and then to Yandev, which is in Northern Nigeria. After seven years of service in the Nigerian agriculture department, he was appointed Deputy Assistant Director of Agriculture. Only six months after assuming this position, he was named the Assistant Director of Agriculture. His promotion in the Nigerian service was rapid and in most cases he received his promotions over those who were more senior to him. During his farewell party, the African staff wrote in their speech:

Barely seven years after your appointment you were promoted Deputy Assistant Director of Agriculture, and the following year, that is six months after your first promotion, you were appointed Assistant Director of Agriculture, in each case superseding more senior officers. Those in-born qualities of which you are so remarkably possessed and of which you early gave evidence when you were serving as a Superintendent of Agriculture received adequate recognition when it was necessary for Mr. Faulkner to relinquish his appointment as Director of Agriculture, and you were considered, throughout the whole Colonial Agricultural Service, to be his fittest and worthy successor on the $31^{\text {st }}$ of October, $1936 .{ }^{180}$

Though loved and respected by the staff in the agriculture department and the African authorities ${ }^{181}$ he found himself constantly in conflict with the administrative/political officials. It was these conflicts that drove him to early retirement from the Nigerian service. Though a great patriot of the British Empire, he fought for better conditions for

\footnotetext{
${ }^{180}$ A Valedictory Address Presented by the Entire Staff, agricultural department, Nigeria, on the retirement of James Mackie, 16 February, 1945, Mackie Papers, Rhodes House (Hereafter, RH): MSS. Afr. S. 823.

181 Throughout this work, I shall use African authorities, local authorities, or local administration to refer to the African rulers such as the Emirs, warrant chiefs, etc. This is used to replace the colonial terminology of Native Administration or Native Authority.
} 
African staff in his department. I see his agricultural policy as being fourfold - the training and education of African agricultural officers; the expansion of research and experimental farms; close collaboration with African authorities and the expansion of mixed farming. His agricultural planning before and during the war was influenced by this view. The purpose of these policies was to expand agriculture production in Nigeria that would not only help Nigeria but, more importantly, the British Empire. He was very passionate about these goals and this passion was in most occasions the source of the conflicts between him and the administrative officials in Nigeria.

\section{Elite Mediation and Agricultural Development}

At the time of Faulkner's retirement from the Nigerian agricultural service in 1936, no one in the agricultural department was a better replacement for Faulkner than Mackie. They had collaborated very well together and were pioneers in the investigation of agricultural systems used by peasants. They wanted to understand peasant cultivation and they paid particular attention to local knowledge. Joseph Hodge writes that, "The greater attention Faulkner and Mackie gave to local agricultural practices reflected, in part, the phenomenal growth of peasant commodity production of both food and cash crops, not just in tropical Africa but throughout much of the colonial empire in the early decades of the twentieth century." ${ }^{182}$ In order to effectively understand peasant agriculture and build upon it for the expansion of production, they saw the need for working closely with the African authorities. Though this approach was peasant friendly, it was restricting and limiting to development. The reason is because they were

\footnotetext{
${ }^{182}$ Hodge, Triumphant of the Expert, 149.
} 
attempting to expand peasant production through innovations without making dramatic changes to the social structure and farming organization. Thus, they sought the cooperation of African authorities in this quest. This approach, adopted by Faulkner and Mackie to the development of agriculture, was similar to the policy of indirect rule introduced earlier by Lugard.

By applying this policy to the development of peasant agriculture, Mackie was using some form of elite mediation as a key to development. By advocating a policy that limited dramatic change in the colony, Mackie was either consciously or unconsciously accepting the assumption that the peasant farmers were insusceptible to change. This is one of the unfortunate assumptions ingrained in colonial rule. ${ }^{183}$ Mackie's assumption was that Nigerian peasants were inept to change and this was not the case. As I have shown in the first chapter of this work, the adoption of cocoa farming in western Nigeria was the initiative of the peasant farmers who saw the economic benefits of cultivating cocoa. This notion of peasants ineptitude toward change in agricultural practices had a negative impact on the planning and development of agriculture as the planners were more interested in policies that would enshrine the status quo rather than upstage the system toward better results.

\footnotetext{
183 Suzanne Moon provides a compelling case of such an ideology in her work on development in the Netherlands East Indies. She shows how the colonial state from the beginning of the twentieth century to the late 1920s had the assumption that the Javanese society was static and thus they developed their agricultural policies on the faulty assumption that the Javanese people could not be relied upon to change, even though the colonial state really wanted them to change. Thus, they favored technologies that were not going to bring about any social reorganization of farming, while at the same increasing yield. As her work shows, Javanese society was not inept to change. See Suzanne Moon, Technological and Ethical Idealism: A History of Development in the Netherlands East Indies (Leiden: CNWS Publications, 2007).
} 
As Assistant Director of Agriculture, Mackie wrote a memorandum in August of 1930, outlining a scheme for the extension of agricultural development by engaging fully the African authorities. This scheme, which was accepted by Faulkner and promoted vigorously by Mackie, deserves close study and analysis. Mackie's scheme was intended to build a close working relationship between the department and the political officers in order for the department to effectively carryout extension work. The relationship between the officers of the agricultural department and the political officers that worked with traditional administrations was a rocky one. The staff of the agricultural department was prevented by the political staff from working directly with the emirs and their officials. The professional department officers were treated as enemies and as outsiders and thus should be kept as far away as possible from the African authorities. The political officers distrusted the technical officers having a close official relationship with the African authorities. Though the political officer drew his salary from the government, he saw himself as an official of the African authorities while at the same time treating the technical staff as government officials who should not exercise any role in the administration of African affairs. ${ }^{184}$

There were two reasons advanced by the political officers as to why the department staff should not play any role, not even an advisory one, to the local administration. The first reason was that the local administration was young and delicate and had to be protected. They saw the presence of the technical department staff as

\footnotetext{
184 Mackie, Proposals for the Closer Collaboration with Native Administration for the promotion of Agricultural Development, 2 August 1930, Mackie Papers, RH: MSS. Afr. S. 823 (4).
} 
interference from the outside. ${ }^{185}$ This interference, they believed, would force the African authorities to move at a pace that they were not capable of at the time. The question then is, did the African authorities need protection from the political officers? For the colonial state, this was an attempt to maintain stability. The principle of indirect rule in Nigeria was geared toward maintaining the status quo of a traditional African bureaucracy. As Harry Gailey argues, this form of rule was "simply to the advantage of the chiefs and the people to accept the 'indirect' form of government since it did preserve intact some of their laws and practices, and retained for the chiefs the right of low-level decision making." 186 The African authorities in the colonial state were instruments used in the colonization of the people. The role of the Residents or appointees to these authorities was to make sure that their rule conformed to the dictates or expectations of the colonial state. For this reason, they saw the direct access of the technical department staff to the rulers as interference in a bureaucratic structure of the colonial state. The agricultural department under Faulkner and Mackie respected traditional cultivation methods and felt they only needed the opportunity to provide technical advice to the African authorities toward expanding production. Expanding production was not only good for the colonial state but also good for the Africans. This view of careful technological intervention in peasant production rested on the assumption that peasant production was stagnant because of lack of innovation in the practices and the technical departments had a solution to this problem. By carefully introducing best farming and innovative practices

\footnotetext{
185 Ibid.

186 Harry A. Gailey, The Road to ABA: A study of British Administrative Policy in Eastern Nigeria (New York: New York University Press, 1970), 5.
} 
to the farmers, a significant expansion would occur in production. ${ }^{187}$ It is important to state that it was not just the agricultural department that the political officers were against interfering in traditional administration. They were against other departments as well. By doing this, they restricted the indigenous rulers and their officials from having unfettered access to the advice of the technical experts.

The second reason, according to Mackie, for the prevention of the technical departments' staff from playing a role in local administration was that political authorities believed the technical departments were "trying to undermine the influence of the Native Administration by creating enclaves which were independent of it." ${ }^{\prime 18}$ At issue here was the colonial state's goal of maintaining stability by subjecting all the people within the umbrella of the African authorities. They did not want the people whose livelihood and economic means were independent of the authorities to challenge the political structure that was now being maintained by the state. This policy, like the one on land tenure earlier discussed in the first chapter of this work, was geared toward maintaining the stability of the state. ${ }^{189}$ For these reasons, the political officials were vigorous defenders of the local authorities. Apart from the goal of maintaining stability in the state was also the unbridled desire for power and control. The political officers, who were often less experienced than the experts from the departments, wanted to exercise control over the African authorities. They did not want to see their own positions being undermined by

\footnotetext{
187 Suzanne Moon, "The Emergence of Technological Development and the Question of Native Identity in the Netherlands East Indies," Journal of Southeast Asian Studies 36 (2005): 201. 188 Ibid.

${ }^{189}$ See Steven Pierce, Farmers and the State in Colonial Kano: Land Tenure and the Legal Imagination (Bloomington: Indiana University Press, 2005) and Robert Shenton, The Development of Capitalism in Northern Nigeria (London: James Currey, 1986).
} 
the African leaders who may go directly to the technical experts for advice in the different things. Mackie stated that though agriculture was the staple industry of Nigeria, "practically nothing is spent by Native Administration in trying to encourage it, and although every political officer has some little pet scheme for the development of Agriculture in his own particular Emirate the assistance of Agricultural Officers has with few exceptions never been welcomed, presumably because the Political Officers feared that they might gain too much influence with the Emirs etc." ${ }^{\prime 190}$ Though the political officers were not technical experts in the sense of the officers from the technical departments, they were experts in their own way. Many of these officials often spent several years working in the same district or village and with the same emir or chief and had a good grounding in the language, culture and knowledge of the local people. Though they may not have known their science as the experts from the technical departments, they knew their natives. While the lack of consultation and inclusion of agriculture officers in the local schemes led to the failure of some of these schemes, it is also true that the arrogance of scientific men who thought that their ideas were the most rational and that local practices were primitive and backward also contributed to the failure of many schemes.

Mackie's proposal was intended to change this frosty relationship between the technical officers and the political officers and also form a closer working relationship with the traditional administration without making the political officers feel threatened. He saw the role of the agricultural department officers solely as that of offering technical

\footnotetext{
190 Mackie, Proposals for the Closer Collaboration with Native Administration for the promotion of Agricultural Development, 2 August 1930, Mackie Papers, RH: MSS. Afr. S. 823 (4).
} 
advice to the African leaders without meddling in the affairs of the administration. This was an unrealistic expectation because it was impossible to change the African farming system without affecting the political affairs. The reason is because the farming system was closely linked to the political system. The land tenure system which the British had supported from the early years of colonization vested authority in the hands of the local rulers. The farming system could only be changed to an extent because the policy of indirect rule limited the possibilities for change. To radically change the system and increase production, the power over the control of land and labor had to be removed from these local authorities, which would invariably create cracks on the foundation upon which the colonial state rested. The contradictions of this colonial policy was the reason that by the 1940 s, colonial developers and planners began to move toward using educated elites and capitalist farmers as intermediaries rather than continuing to collaborate with traditional rulers.

Mackie's proposals were not fundamentally changing the status quo but enshrining it in a new collaborative form. In his memorandum, he laid out six proposals toward changing this relationship. He proposed that they should start an experimental farm under the authority of the local administration. The emir's agricultural adviser's headquarters would be located on this farm and would be responsible for demonstrating improved methods of farming and providing extension and later on, a place for agricultural development. Mackie thought that Katsina Emirate would be the most suitable place to start but did not feel strongly about this decision. He emphasized the point that the role of the agricultural official was purely advisory and so would not 
assume responsibility over the farm. He wrote, "the executive officer in charge of the farm and all its staff should be Native Administration officials, paid by the Native Administration and responsible to the Emir and his council." ${ }^{191}$ This proposal was necessary to placate the political officers who might feel that the agriculture department staff was trying to usurp their power and gain control over the local administration. The agricultural officer assigned to the farm reported on technical matters to the Assistant Director of Agriculture just as he would in government owned farms. It was the responsibility of the executive manager of the farm to send accounts and reports directly to the emir and his council and not to the Assistant Director of Agriculture. Mackie also proposed that the farms owned by the local administration would not perform complicated scientific experiments but would follow the pattern of demonstration farms. The conduct of scientific experiments would be restricted to government owned farms. He saw a future in which these farms would become farm schools where people would come to learn improved methods of farming.

The emphasis for both Faulkner and Mackie was an understanding of African systems of agriculture. Any attempt by the technical officials was meant to improve the production of the locals. For this reason, they were very careful in asserting that the farms they established hand in hand with the African authorities must be demonstration farms rather than farms that would carry out complex experiments. Whatever was shown in demonstration farms had to be tried and proven to improve the production of the farmers, without this, the farmers may not adopt the methods. What they were offering was a new

${ }^{191}$ Ibid. 
perspective to agricultural expansion in Nigeria and the rest of tropical Africa. While this policy was peasant friendly, it was also colored by racial attitudes. This philosophy was paternalistic and racist in the sense that it created a two tier structure: the European scientists in the technical departments would conduct the scientific trials and research on stations owned by the government and the local farms were only for demonstration purposes and for the dissemination results. This discounted the ability of the locals to produce knowledge. They had to be reliant on the Europeans as the producers of knowledge. From this viewpoint, the Africans had no science and their knowledge was backward. They were placed in a situation in which they can only be receivers of knowledge and not producers of knowledge.

Some of the officials who had previously worked with peasant farmers had displayed arrogance of the highest magnitude, accusing the peasants of being deprived of any good knowledge of farming or order. African farming systems such as bush fallow rotations and intercropping were alien to the British and thus they considered them unproductive. This bush-fallow system was similar to crop rotation practiced in Britain but in the case of Africa, the plots were allowed for several years to return to natural vegetation. This was different from the British approach in which during the fallow period, grass and legume were used to restore soil fertility. Thus, to those used agriculture in Britain, the African system was a mess. ${ }^{192}$ Farmers in West Africa were castigated as "for 'wasteful' burning of vegetation, 'merely scratching the surface' of their soils, 'failing' to plough deeper, lazily mixing their crops in an arbitrary and

\footnotetext{
192 William Buhler, Stephen Morse, Eddie Arthur, et. al., Science, Agriculture and Research: A Compromised Participation? (London: Earthscan Publications Ltd., 2002), 44.
} 
unhygienic manner." ${ }^{193}$ George Howard Jones, an agricultural officer in Nigeria in the twenties, wrote a book challenging these assumptions. In describing the West African farmer, he wrote,

... there seems a reason for everything. The plants are not growing at random, but have been planted at proper distances on hillocks of soil arranged in such a way that when rain falls it does not waterlog the plants, nor does it pour off the surface and wash away the fine soil: the stumps of bushes and trees are left for the yams to climb upon and the oil palms are left standing because they yield valuable fruit: and although several kinds of plants are growing together, they were not sown at the same time nor will they be reaped together: they are rather successive crops planted in such a way the soil is always occupied and is neither dried up by the sun nor leached out by the rain, as it would be if it were left bare at any time. ${ }^{194}$

Jones made the point that Europeans should be cautious and thorough before they pass any judgments on the Africans. He said that the African method of farming and the farmer's outlook is so different from the European that the latter might be tempted to dismiss it as foolish. He said the Europeans made the same mistake in India. He argued, "In assessing native agriculture, then, we have to guard against condemning native methods merely because they offend European temperate agricultural principles, and in addition we must be prepared to grant that there may be reasons for his peculiar methods of which we know nothing, even after we have considered them as carefully as we can with our present knowledge of tropical agriculture."195

Growing up among peasant farmers in rural Nigeria, I beg to agree with Jones' observation. In a typical planting field, the Bette people of Cross River State would have

193 Paul Richards, Indigenous Agricultural Revolution: Ecology and Food Production in West Africa (London: Hutchinson, 1985), 43.

194 George Howard Jones, The Earth Goddess: A Study of Native Farming on the West African Coast (London: Longmans, Green and Co, 1936), 35.

195 Ibid., 35-36 
hips with yams planted. The hips are made in such a way that the land would not suffer from erosion. Depending on the soil, the hips have to be of a certain size. This is knowledge perfected over many years. Four hips were crossed with wooden sticks to allow the yam branches to grow on those sticks. In some areas, each yam hip had a long stick planted on it to allow the branches to grow on that stick. This allowed the yam tubers to receive the sunlight they needed for proper growth. Apart from yams planted on the hips, other staple food crops are also planted: maize, cassava and round peas. Corn takes about three months to be matured for harvesting. It is planted alongside the yams immediately. It would be harvested early before it becomes an obstacle to the growth of the yams. Cassava was also planted as soon as the yams were planted. It took longer to grow than the yams. It was usually harvested a year after the yams had been harvested. The round peas were also planted alongside the other crops. The reason was that they needed a stick to grow on and since the yams needed sticks for their branches to grow on, they could share one stick. These crops are not planted without order. Local knowledge built up over several years convinced the people that they could plant all these crops alongside each other on one piece of land and still acquire a bountiful harvest. There are two reasons why this approach is important: labor and land conservation. A bountiful harvest is a relative measurement. For a big agro-farmer in the midwest of the United States, the output of most of the Bette farmers would be considered a miserly and not worth depending upon. The reason is because he considers farming a business from which he should derive as much pecuniary benefits as possible. For the Bette traditional peasant farmer, a bountiful harvest means something entirely different. It means producing enough food to feed his family, as well as a surplus to market to pay his taxes 
and make his communal financial contributions. His agricultural production is influenced by labor. Given that the peasant is not an industrial agriculturalist, he wants to be able to maximize his family labor. The number of people within the family or a village unit often determines the amount of production. As Goran Hyden argued, "Peasants are essentially self-sufficient and self-reproducing, either within the context of the household or the village. In other words, each unit of production is separated from each other, they are socially independent, united by no social division of labor, and depending on no other unit for their conditions of reproduction." ${ }^{, 196}$ Due to the independent nature of peasant production and the family as the primary economic unit of production, labor had to be maximized. Thus, many peasant farmers embraced polygamy and had many children as a secure source for labor. ${ }^{197}$

A good example given by Faulkner and Mackie in their book, West African Agriculture is the introduction of American cotton to Southern Nigeria. Southern Nigerian farmers were unwilling to adopt the new crop variety even though it would have provided a better yield than the local cotton variety. The reason they refused to adopt it was because it entailed clearing a new piece of land and growing it as a sole crop. This was extra labor that the farmer did not have, because it was a family economy where labor was principally provided by family members and even where wage labor was present, it was very limited or some of the farmers could not afford it. It made more sense to him to continue to grow his own cotton, which could be grown on the same land with

196 Goran Hyden, "The Resilience of the Peasant Mode of Production: The Case of Tanzania" in, Agricultural Development in Africa: Issues of Public Policy, eds. Robert H. Bates \& Michael F. Lofchie (New York: Praeger, 1980), 221.

197 Toyin Falola, Culture and Customs of Nigeria (Westport: Greenwood Press, 2001), 139. 
other crops, yielding a fair return. When the farmer was provided with an improved variety of the native cotton, he immediately adopted it because he could grow it alongside other crops. ${ }^{198}$ The reason the Bette peasant farmer has four crops in the same piece of land is because it saves him the labor of clearing another piece of land. Would he acquire a better output if he had each of the crops planted separately? Probably he would. However, the problem of labor would make him less inclined to do that.

The understanding of African methods was of great importance to both Faulkner and Mackie. Take for example, the Bette farmer's choice to plant several crops in the same piece of land. This is necessary for the conservation of land. The Bette farmer traditionally allowed a piece of land to fallow for about five to six years before they returned to it to plant. This period was even longer when there wasn't pressure on the land as there is today. Colonial officials often erroneously made the argument that tropical African peasants had no respect for land and they destroyed it shifting cultivation or bush fallow farming. This system of farming which was prevalent in West Africa involved farmers slashing and burning a piece of land, cultivate it for a few years and then move on to another piece of land. Colonial officials thought that this system was bad because it was "exploitative, untidy and misguided." 199 In their thinking, natural forests were constantly being destroyed in order to find virgin soil for cultivation. ${ }^{200}$ For example, the Kenyan settler businessman, Major E. S. Grogan testified to the 1933 Kenya Land Commission that, "the African people, have never established a symbiotic

198 O. T. Faulkner \& J. R. Mackie, West African Agriculture (Cambridge: Cambridge University Press, 1933), 11.

${ }^{199}$ Richards, Indigenous Agricultural Revolution, 50.

200 Ibid. 51. 
relationship with land. They are, in the strict scientific sense, parasites on the land, all of them." ${ }^{201}$ This was a bold statement from someone who was ignorant of Africans' generational relationship with the environment and land. ${ }^{202}$ This was an argument that was often made during the early period of colonial rule. One criticism that was often made was that, African practices caused soil erosion. Helen Tilley devotes a fair portion of her book, Africa as a Living Laboratory, to show that African agricultural practices for the most part were not as destructive of the land as some of the European settler farmers and colonial officials had claimed. Most of the failure in crops was not the result of what Africans were doing wrong but was the fault of the tropical soil that was not as fertile as had been initially assumed. Tilley writes, "In a discussion of the causes of soil erosion at the second conference of colonial directors of agriculture in 1938, C. J. Lewin of Northern Rhodesia remarked that the papers presented showed that, contrary to popular opinion, 'erosion was almost invariably due primarily not to the native but to the European who had introduced tillage in certain areas and had encouraged the production of economic crops." ${ }^{\prime 203}$ While this is debatable, what is important to note is that in the most part, African practices were not as destructive to land as it was claimed. The argument that shifting cultivation is destructive to land when there is limited land and rapid population growth has recently been challenged by recent studies. In a case study of Machakos district in south-east Kenya, Tiffen, Mortimore, et.al write that the colonial

\footnotetext{
${ }^{201}$ Major E. S. Grogan, cited in Kianne Rocheleau, Philip Steinberg \& Patricia Benjamin, "Environment, Development, Crisis, and Crusade: Ukambani, Kenya, 1890-1990," World Development 23.6, (1995):1042.

202 Recent scholarship has challenged the notion that Africans have been ineffective in managing their environments thereby causing environmental degradation. See Melissa Leach \& Robin Mearns, eds. The Lie of the Land: Challenging Received Wisdom on the African Environment (Oxford: James Currey, 1996).

${ }^{203}$ Helen Tilley, Africa as a Living Laboratory, 157.
} 
government in the 1930s had deep concerns about land degradation and had ambitious plans to curb it. The solutions to the problem rested in one of the false assumption that population growth was harmful to the environment because it meant fewer trees. They argue that when there is population growth in agricultural areas, there is a change that takes place in the farming and incoming systems. They write, "Farmers can adapt by innovation and investment and can develop new sustainable systems, but government policies can either impede or assist this process." ${ }^{204}$ Even though the population of this region had continued to grow, erosion had also continued to reduce. This reduction was not as a result of changes in the cropping system by improvements in terracing. ${ }^{205}$ Many of those who engaged in scientific research in the 1930 s were voices of moderation, calling for the application of some of the best practices of the peasant farmers. The director of the Ugandan agricultural department, for example, recommended the incorporation of African customs into "regional policies, particularly in terms of crop rotations and soil protection measures." ${ }^{, 206}$ This change in attitude resulted from research and closer observation of African agricultural practices.

A fair share of African historiography today dismisses the role that European scientists played in colonial Africa. These European scientists are accused of being "oriental" toward African practices. These scientists have been accused proffering solutions to problems that they did not understand because of their lack of understanding of African environments and their dismissal of African practices as being backward or

204 Mary Tiffen, Michael Mortimore, et.al, More People, Less Erosion: Environmental Recovery in Kenya (Nairobi: Acts Press, 1994), 13.

205 Ibid., 118.

${ }^{206}$ Helen Tilley, Africa as a Living Laboratory,158. 
primitive. While there is some evidence of these problems, it is also true that colonial science played an important role in the imperial project. Most of these scientists spent several years working in Africa or in other colonial states and they shared their research with one another through scientific journals and conferences. Some of these scientists may have moved regularly, "but they nevertheless accumulated experience and knowledge of particular issues, and their careers demonstrated a professional continuity. ... Such scientific officials also drew on a wider range of experimentation and information than they could generate from their own research or from their particular colonial contexts. They shared information through correspondence, scientific journals, conferences, and government agricultural publications. ${ }^{207}$ Most of the interventions that took place during the colonial period were experimental and so the outcomes were unpredictable. The experimentation and networks forged by these scientists helped to provide the foundational basis for understanding African environments and diseases. ${ }^{208}$ These networks of knowledge and trans-continental colonial experience formed the basis for the understanding of Nigeria's agricultural practices. Faulkner brought knowledge acquired in India to Nigeria and this was instrumental in his work in the agriculture department. Faulkner and Mackie were willing to share their own experiences of Nigeria agriculture, which they had paid very closed attention to for many years by writing a book on West African Agriculture to educate colonial officials assigned to both the administrative and agricultural departments in West Africa. ${ }^{209}$ They felt that an

207 William Beinart, Karen Brown, et.al, "Experts and Expertise in Colonial Africa Reconsidered: Science and the Interpenetration of Knowledge," African Affairs 108/432 (2009):420-421.

208 Ibid., 433.

${ }^{209}$ Faulkner and Mackie state this intention in the preface of their book. They wrote, "This book is written especially for the candidates of Government service in West Africa in the Administrative and 
understanding of West African agricultural practices would enable the official to be less judgmental, less arrogant and more successful in their work. This book became so significant that it was included "in a list of books of 'first importance' for Malcolm Hailey to read when he assumed the role of director of the African Research Survey in 1933." ${ }^{210}$ Given the degree of knowledge that African farmers possessed, it was important that the European approaching an African farmer must do so with humility. He should not be so arrogant to think that he knows what is best for the peasant and that his own methods are superior to those of the peasant. Faulkner and Mackie argued that it is not surprising that the African farmer is suspicious of the advice that is given to him by the European. He is suspicious because "His own methods have been evolved and adapted during many generations, so that they suit local conditions and also suit his economic position, his social arrangements, his psychology and his tastes. It will generally be found that by them he obtains a maximum return from a minimum of labour." ${ }^{211}$ In their view, the European official must take all those factors into consideration as he tried to introduce a new crop to the native farmer or when he asked him to change his methods. They were not against the introduction of new methods or new crops, after all they successfully implemented mixed farming in Northern Nigeria. What they called for was research and experimentation of crops before they were introduced to the African farmers. One may ask, if the African farming is so well adapted to the local environment and meets the farmers needs, why does it need to change?

Agricultural Departments; but we hope it may prove useful or interesting to those who intend to come out as missionaries." Faulkner \& Mackie, West African Agriculture, vii.

210 Helen Tilley, "African Environments \& Environmental Sciences: The African Research Survey, Ecological Paradigms \& British Colonial Development 1920-1940," in Social History \& African Environments, William Beinart \& JoAnn McGregor, eds. (Athens: Ohio University Press, 2003), 118.

211 Faulkner \& Mackie, West African Agriculture, 6. 
Faulkner and Mackie believed that the local practices could be improved upon or changed if necessary to improve production. In some cases, this meant improved seed varieties or other methods of improving soil fertility.

\section{Wartime Agricultural Planning}

With the retirement of Faulkner in 1936 and the appointment of Mackie as the Director of Agriculture, agricultural development in Nigeria continued in the same trajectory it had taken since the 1920s. Mackie had worked closely with Faulkner and they both shared the same vision for agricultural development in Nigeria. The early years of Mackie's leadership of the department were spent planning in anticipation for the war. Mackie demonstrated great vision and foresight in this direction. Even before the circular was sent from the $\mathrm{CO}$ to the agricultural departments of the colonies instructing them to begin reorganizing and planning for wartime, Mackie had already taken the initiative. While the governor was still looking at agriculture in Nigeria from a business point of view, Mackie was raising an alarm that Nigeria's position as an important source of raw materials in time of war was being overlooked. In a memorandum to the Chief Secretary to the government (CSG), he wrote:

The possibility of war cannot even now be overlooked and in such an event it should be noted that Nigeria could if properly developed supply almost every product which can be grown in the tropics; and moreover of the large tropical colonies she is nearer to England than any other. By speeding up the shipping services she could easily be brought to within 10 days of England and the sea route could be made comparatively safe. It seems to me therefore that the Agricultural development of Nigeria is a matter of vital importance to the Imperial Government, especially as she would not herself require supplies 
which are needed elsewhere for the prosecution of the war, for she could if necessary become self supporting for greater bulk of her needs. ${ }^{212}$

Mackie was attempting to position Nigeria for wartime supply of raw materials and this was an important strategy. The other big British colonies such as Kenya and India were closer to the combat zone than Nigeria. Ghana which was also in the west coast of Africa and closer to London than Nigeria was a smaller colony and had a population of less than 4 million in 1939. For Mackie, the size of Nigeria and the potential the colony had could not be ignored. Nigeria's strategic importance during the war and Mackie's goal of developing agriculture had as a primary goal, the exploitation of Nigeria's resources for the benefits of Britain.

Mackie wanted to have a strong department that would be capable of supplying what the imperial government needed during the war. In February of 1939, he sent a letter to the governor inquiring if officers of the forestry and agriculture departments would be released for military service in the event of war. This question was important because he was interested in seeing how the department staff could be reorganized in preparation for war. He did not want production to be affected by the absence of these officers. ${ }^{213}$ The CSG responded that as a general rule, officers of these departments would not be released for military service. The reason was reached because of the importance those two departments played in the provision of adequate supplies of raw

\footnotetext{
${ }^{212}$ Mackie Papers, Mackie to CSG, 4 January, 1939, Mackie Papers, RH: MSS. Afr. S. 823.

${ }^{213}$ Mackie to CSG, 22 February, 1939, Mackie Papers RH: MSS. Afr. S. 823.
} 
materials. ${ }^{214}$ Mackie was not just satisfied that the staff of the departments wouldn't be released for military service. He wanted to be sure that the work in the two departments would be recognized as a major contribution to the war. He wrote again a few weeks later to the CSG, “...it will not be a very satisfactory position for us unless we can feel assured that the work we are doing is essential for the successful prosecution of the war. To those of us who are fit for military service and are quite prepared to take such service, merely carrying out our peace time duties would be a very severe trial." ${ }^{215}$ It wasn't that Mackie was willing to abandon his agricultural post to rejoin the military to fight the war. Mackie was making a larger point. To a great extent, Mackie was using the pretext of the war to further his agenda of expanding the department's services. Not doing that at this time of great demand meant that he was wasting his time. Thus, he felt that if the department was not going to be given an expanded role, then it would be better for him to join the military than to work in the department. Mackie never felt satisfied with the support he got from the political officials. This feeling would follow him throughout his tenure in the department. To buttress the point he was making, he continued in his letter: "I therefore feel obliged to ask whether the Government proposes to take any preparatory steps to ensure that we shall be in a position to increase production rapidly, and whether I may receive some indication of the products which Nigeria will be called upon to supply and whether the Government anticipates that in the event of war Nigeria will have to be self supporting as far as its own food requirements are concerned." 216

${ }^{214}$ CSG to Mackie, 16 March, 1939, Mackie Papers, RH: MSS. Afr. S. 823.

215 Mackie to CSG, 11 April, 1939, Mackie Papers, RH: MSS. Afr. S. 823.

216 Ibid. 
Of interest to him was the rapid expansion of agricultural production and without that, the department was not making a substantial contribution to the war. Food production would have to be enough not only for export but also for local consumption. Mackie said that four assumptions must be made as they think about agricultural production at this time: the war would likely break out in about a year at a time when there would be partial drought in some parts of Northern Nigeria; shipping would be dislocated in some months and it would be difficult to rapidly receive foodstuff in large quantities from elsewhere; Europeans left in Nigeria would have to serve for two or three years without leave; and finally, that the Mediterranean sea route might be closed and there might be an urgent need for Nigeria's surplus products at short notice. If his assumptions were correct, he argued, then it was important that throughout Nigeria, there should be reserves of foodstuffs. He wanted this to happen immediately before the war broke out. He also wanted the welfare of the Europeans serving in Nigeria to be seriously taken into consideration. If the war meant that Europeans would have to undertake longer tours of duty in Nigeria, then in order for them to remain fit, he argued, there was need to provide them with some essentials which Nigeria can provide. He wrote, "Thus if transport existed and preparation was made beforehand it would be possible to ensure that most Europeans situated within reasonable distance of the railway at any rate could be supplied with fresh milk, meat, and fresh vegetables from the North and fruit and fish from the South. Such amenities would do much to maintain them in a good state of health."217

217 Ibid. 
Mackie had been thinking about the contribution of the agricultural department as soon as the drumbeats of war were sounding. He understood the agricultural geography of the world and he knew what could be obstructed by the war and which colonies would be able to make substantial contributions. For him, Nigeria was in a strategic position to provide the wartime agricultural supplies to the imperial government and also to be selfsufficient in some things that Nigeria imported. Nigeria at this time imported rice and sugar. He believed that Nigeria could be self-supporting in these two. He argued that Nigeria's climate is suitable for the cultivation of rice. And also, Nigeria just as India, could be self-supporting in crude sugar such as the gur type. Nigeria grew sugar canes and people mainly ate the canes. The production of sugar cane could be expanded. What would be needed was simple crushing machinery and a boiling apparatus like those used in India. Mackie also believed that oil seeds, such as groundnuts and cotton, could be rapidly expanded insofar as the department was properly organized for this expansion. At that moment, the department could not carry out such rapid expansion because of the dearth of supervisory staff. Staffing was viewed as one of the primary obstacles to agricultural development in this period. It was not only the European staff that was inadequate, but the African staff was inadequate as well. Mackie devoted a lot of time proposing ways to ameliorate this problem. He wrote, "An adequate staff is essential whether to improve Agriculture in peace time or to develop production rapidly in war time. At the present time our African staff is totally inadequate for either, and unless it is increased rapidly as possible I have no hesitation in saying that Nigeria will not be in a position to pull its weight in the event of war. ${ }^{, 218}$ Mackie saw his proposals as being very

${ }^{218}$ Ibid. 
important and wanted the colonial government to act on them. He even suggested that the governor could draw from the Nigerian reserve to begin the implementation of his proposal and then discuss reimbursement with the Imperial Government later.

In July of 1939, Mackie received a response from the CSG. He was told to organize his staff on a war basis so that, in the event of a war Nigeria, could facilitate maximum production of materials that will be of service to the United Kingdom. He was to report such a plan to him. The CSG's letter can be interpreted as either a gross misunderstanding of Mackie's last letter, or he was just playing along with the director. Mackie had suggested that the men in the departments of agriculture and forestry would opt for military service if their work in the departments was not an essential contribution to the war. The CSG's response to that was, “...while his Excellency [the Governor] fully realises the Agricultural Officers would be anxious to participate in active military service in the event of war, he considers that they would be contributing their share of national service in a greater degree by increasing to the maximum extent the output of the raw produce of Nigeria." ${ }^{, 19}$ As I have argued earlier, what Mackie and his staff needed was the support of the governor and the officials, support that was not always prevalent. Whatever the intentions of the governor, Mackie found the CSG's letter reassuring. He was reassured by the stated intentions of the governor that the agriculture department would be offering national service by increasing to the maximum extent Nigeria's agricultural produce. This Mackie saw as a statement of support by the governor. With

\footnotetext{
${ }^{219}$ CSG to Mackie, 17 July, 1939, Mackie Papers, RH: MSS. Afr. S. 823.
} 
this assurance, Mackie set to work to produce a policy and reorganization plan for the agricultural department.

In October of 1939, Mackie presented his policy to the CSG and to his senior agriculture officers throughout Nigeria. In his memo he made the point that if Nigeria must maintain maximum production all efforts must be made to make sure that the fertility of the soil is maintained. To do this, he argued that the basis of their efforts must be mixed farming ${ }^{220}$ in the Northern region of Nigeria and work on green manuring and compost making in the southern region. ${ }^{221}$ Faulkner and Mackie had long championed mixed farming in Northern Nigeria. In their book West African Agriculture, they devoted a chapter to discussing mixed farming in Nigeria. Their idea of mixed farming they wrote, was "one in which every farmer owns cattle of his own, say two bullocks and one or two cows, together with his usual head of sheep, goats and fowls. He would keep his cattle in a pen and supply them with bedding, thus making farmyard manure of the highest quality all the year round. His bullocks would be used for ploughing, thus solving the labour problem; and his cows would breed calves and supply him with milk for his family or for sale." 222 They believed that such a system of farming was going to lead to the prosperity of the farmer and the country as a whole. They were even surprised that such a system had not been introduced into the country long before. There were two main problems why mixed farming had not been widely adopted. The first problem was the fear of epidemics such as Rinderpest. About three fourth of cattle were wiped out when

\footnotetext{
${ }^{220}$ Mixed farming is method of farming in which there is a mixture of arable farming with the raising of livestock.

${ }^{221}$ Confidential Memorandum by Mackie, 26 October, 1939, Mackie Papers, RH: MSS. Afr. S. 823.

222 Faulkner \& Mackie, West African Agriculture, 64-65.
} 
there were epidemics. ${ }^{223}$ Another problem was the cost of keeping cattle and the product output that resulted from the farm animals. It was expensive to feed the animals and in some cases there wasn't substantial cleared land available for cultivation. ${ }^{224}$ Faulkner and Mackie had tried mixed farming among a small group of farmers and they saw tremendous results. Farmers who adopted this system of farming saw growth not only in the amount of land they cultivated but also better yields. Farmers who were cultivating only three acres of land could now cultivate ten or twelve acres because the bullocks would help with plowing and enough manure was produced for the fields. ${ }^{225}$

One major problem with mixed farming was that of finding a suitable type of plow. Not only did the plow have to be suitable technically, it also had to be affordable because the African farmer had little or no access to capital. Several attempts that were made in the past by European missionaries and administrative officers failed because the type of plow chosen was unsuitable. Faulkner and Mackie felt that there was now a solution to this problem. What was needed was a double-breasted ridging plow. These plows could be made out of wood and cold be easily made by the village craftsmen. They wrote, "The wooden ploughs now in use can be made locally for less than $£ 1.10$ s. $0 \mathrm{~d}$., and they do quite satisfactory work. They have been used exclusively for all the ploughing on our experimental farms for the last three or four years, and those native farmers who have tried them have been well satisfied.",226

223 Ibid., 65. See also Richards, Indigenous Agricultural Revolution, 128.

224 B. W. Hodder, Economic Development in the Tropics (London: Methuen, 1968), 113-114.

225 Ibid., 66.

226 Ibid., 67. 
The approach in the southern region, on the other hand, was not mixed farming but green manuring to which they also devoted a chapter of their book. Unlike the north, land was very scarce in the south and there had no cultural tradition of keeping cattle. The north had vast lands that the cattle could graze in. The southern part of the country was already practicing shifting cultivation. Faulkner and Mackie thought of green manuring as the best solution in the south. They defined the practice as "the process of growing a crop simply for the sake of turning it all into the soil as a manure. The plants grown for this purpose were usually one of those belonging to the leguminous family the family that includes beans, peas and clovers. The plants of this family have the unique property of collecting nitrogen directly from the air through the agency of bacteria which live in nodules on their roots. ${ }^{227}$ The reason this system was more ideal in the southern region was because of the heavy rainfalls. The rains washed and leached the soil of its vital nutrients such as nitrogen. Experiments that were carried out for about ten years showed that the use of green manuring would maintain the fertility of the soil. They wrote, "The crops obtained at Ibadan now, after ten years of rotational green manuring and cropping, are as heavy or even heavier than were obtained from newly cleared bush; and they are heavy and very quick-growing crops by any standard."228 Mackie's proposal in the memorandum that mixed farming and green manuring should be used was thus based on several years of investigations and experimentation.

In Mackie's opinion, the policy which he laid down in his memorandum was going to place Nigeria in a stronger position than it had been before the Second World

\footnotetext{
227 Ibid., 52.

${ }^{228}$ Ibid., 58.
} 
War. The first goal was to achieve food self-sufficiency. The first step in carrying out this policy was to make sure that each part of the country was as self-supporting as possible in the staple food crops, and if it is not self-supporting, there must be distribution channels available to quickly and easily move supplies from one area to the next. Not only should the country be self-supporting, but also there should be reserves to draw upon in the event of any emergency such as a drought or a partial failure of crops. The amount in reserves had to be documented to give clear knowledge of what was available to be used in the event of an emergency. He also made the point that in areas where cocoa was the main crop cultivated by the farmer, each farmer must be able to produce enough food for himself and his family. He wanted to avoid a situation where farmers put all their resources into cash crops and thereby had to import food. This was an important measure to reduce as much as possible buying foods from other areas that could have gone into reserves. Large parts of Western Nigeria relied solely on the production of cocoa. If they were not to cultivate the food needed for their family consumption, it meant they had to purchase food from other farmers thereby creating a problem with the policy of each part of the country being self-supporting. The policy of being self-supporting in agriculture was thus extended to even individual families.

The second important step was that of making sure the produce and foodstuff that was previously imported would be produced locally. This was important because during wartime, shipping was bound to be disrupted in certain regions of the world. The agricultural officers were to try to produce this imported produce that was suitable to their climatic conditions. He summarized the duties of the agricultural department during 
war time as those of being ready to help the imperial government with the production of crops that it may request; to ensure that Nigeria is self-supporting in foodstuffs that it usually would import; and finally to do what it could to make West African colonies as a whole self-supporting. ${ }^{229}$ Mackie was convinced that his policy would stimulate industries in the manufacture of native products such as "sacks, baskets, rope etc.,"230 These two objectives that Mackie set out to accomplish: being self-supporting in food and the production of crops for Britain were potentially conflicting, since concentrating too much on one would take away from the other.

Mackie's planning had anticipated the needs of the Imperial Government during wartime. By the time the $\mathrm{S}$ of $\mathrm{S}$ had sent a proposal to the agricultural departments advising them on what to do, Nigeria was well ahead with its own plan. Thus, in response to a circular from the colonial government stating the S of S's proposal, Mackie wrote: “ I think it is safe to say that we in Nigeria have anticipated the Secretary of State's proposals and I think that every important point mentioned in his circular is dealt with in my circular memorandum .... We have indeed gone rather further than merely to carry out the instructions to the letter, for we are also considering proposals for assisting the African to take a greater share in the processing of his own crops and the development of the internal trade in food stuffs." 231 The major points in the S of S circular were that the colony should expand its production capacity and that the whole British colonies in West Africa should be self-supporting.

\footnotetext{
${ }^{229}$ Confidential Memorandum by Mackie, 26 October, 1939, Mackie Papers, RH: MSS. Afr. S. 823.

230 Ibid.

231 Mackie to CSG, 29 December, 1939, Mackie Papers, RH: MSS. Afr. S. 823.
} 
A faithful son of the empire, Mackie wanted to make sure that he and his staff in the agricultural department made an essential contribution to winning the war by producing sufficient quantities of produce and foodstuff as His Majesty's Government may need. As the war started, Mackie became disappointed that nothing much was requested of Nigeria. Though he acknowledged that their first duty was to be as selfsupporting as possible, he also felt that they had a duty to supply Great Britain with the tropical produce it needed. It is important to note that Nigeria was struggling with the policy of being self-supporting at this time. Rice, for example, was not produced in a large enough quantity to stop importation. R. R. Glanville, ${ }^{232}$ who was an expert on rice, toured some of the northern parts of Nigeria and reported that it was possible for Nigeria to be self-supporting in the production of rice if a special survey of the rice area was made and an officer was available to work on rice in the area. Mackie was not in a position to provide an officer for such work. As previously mentioned, having enough staff remained one of the major challenges that agricultural development faced during this period.

Moreover, Mackie and his officers were disappointed with their work because the raw materials they produced in large quantities were not needed by the Imperial Government. The different types of oilseeds they produced - palm, groundnut, beneseed, etc. were all not in need. The only demand that had been made of them was the Cameroon Banana that was produced in the Cameroons. There, efforts had been intensified to meet the demand. Nevertheless, it was too early in the war for Mackie to

\footnotetext{
232 Glanville was a senior agricultural officer in Sierra Leone and seconded to Nigeria as a principal agricultural officer. He was an expert on rice production.
} 
start feeling disappointed that Nigerian produce was not needed for the war. It was in April of 1940 that Mackie was expressing his disappointment, a very short time after the break of the war in Europe. Mackie himself recognized that he was probably a little too impatient. In a letter to the CSG he wrote, "We must still assume that the war will be a long one and there is still time to make preparations even if they may take some time to carry out.... I therefore beg to suggest that a definite enquiry should be sent to His Majesty's Government asking if there is any product which is likely to be required."233 His goal at this point was no longer to plan for the immediate needs but also to start planning for what the future needs of the empire might be. He also thought about some of the products that might be needed. He wrote, "I have heard unofficially that there is a real shortage of fibres of various kinds, and I note that Keyna [sic] has been asked to grow flax. We have never tried to grow flax, and so far jute has not done well in Nigeria, but we can grow sisal, ramie, or sun hemp. Similarly we can grow cotton. If any of these are wanted we could undoubtedly push up production quite quickly if seed supplies were available." ${ }^{234}$ What would undoubtedly remain a major hindrance to fulfilling any of these plans would be finding the adequate staff needed to carry out this work. For Mackie, Nigerian agriculture could not carry on normally as during peacetime. It must make a useful contribution to the war and its contribution was not militarily but economic. This contribution, in his opinion, was not one only made by the agriculture department but was Nigeria's contribution to the war. He went on to suggest that "if officers could be spared for military service now that they are not required for this

\footnotetext{
233 Mackie to CSG, 10 April, 1940, Mackie Papers, RH: MSS. Afr. S. 823.

234 Ibid.
} 
purpose a few officers could be spared for Agricultural service. ${ }^{235}$ For him, these officers need not have any agricultural training. They could help with office work to free up agricultural officers from such duties or they could help with some preliminary work that did not require any agricultural expertise.

However, Mackie felt a sense of non-co-operation from some of the administrative officials. He had a long list of grievances, which he put in a letter to be sent officially to the CSG, Hoskyns Abrahall. He had misgivings about letting such a letter be filed officially and he attached it with a private letter to Abrahall. In his private letter, he expressed his feelings that he was not allowed to pull his weight in Nigeria and felt that he would be useful in other colonies or even back in England to help with the war. He reiterated that other members of the agricultural department shared his feelings as well. He wrote, "I should hesitate to write like this if it was merely a personal matter but all my officers feel the same. Also, it is not a new thing. The whole history of my Department since 1921 shows that almost every scheme which involved work among the farmers has been opposed or obstructed. As far as the North is concerned, in present conditions I can see no point whatever in putting up schemes for the Colonial Development Fund, for I know that I should not be allowed to carry them out." ${ }^{236}$ Mackie saw his policies as being opposed by the political department. Given that agriculture was the staple of the Nigerian economy, it was not a good sign that the director of agriculture felt that his work with the farmers was opposed and obstructed. It was a situation that was not conducive to solid agricultural development. The level of frustration he and the staff

\footnotetext{
235 Ibid.

236 Mackie to Abrahall, 21 May, 1940, Mackie Papers, RH: MSS. Afr. S. 823.
} 
felt was so severe that he was not willing to submit schemes to be funded by the Colonial Development Fund. In order for his department to work effectively, he believed that there needed to be a change in the organization of the colonial state. Though he was feeling frustrated, he did not want to leave Nigeria because in his words, "I like the country and the people and am most anxious to do something for them." ${ }^{, 237}$

Mackie's problem did not stem directly from the governor or the CSG. The difficulties he faced came from other administrative officials and most especially from the chief commissioner of the Northern Province. Some of his grievances were that when he wrote to the colonial government in April requesting preparation for the war, it took about three months before his letter was even acknowledged. When he requested the appointment of a marketing officer, it took over a year before one was appointed and it required the backing of the cocoa marketing committee. He was also frustrated with the fact that even though they were at war, the activities of the department were still governed by the financial secretary's ruling that "there must be no expansion of work and that I must not make work in order to give members of the African staff increased responsibility." ${ }^{238}$ There was a proposal by the governor to increase the production of wheat flour and the agriculture department submitted a scheme for this proposal. However, it took more than six months before it was approved. Correspondences kept bouncing between the central secretariat, the northern secretariat and the agriculture department. While the scheme faced the bureaucratic red tape, the wheat crop had ripened and there was no machinery available for milling it. The chief commissioner of

\footnotetext{
${ }^{237}$ Ibid.

238 Ibid.
} 
the Northern Province also held up the proposals for ordering sugar cane crushers. It took the intervention of the governor for the approval to be received. Mackie's proposal for the storage of food crops was also denied. The chief commissioner of the Northern Province would not approve the proposals for the storage of groundnut seed and was asking to be supplied with evidence that the soils of Kano were deteriorating. Mackie's proposals for making Nigeria self-supporting in potatoes was also returned by the chief commissioner of the Northern Province, informing him that what was wanted was expert advice and not "restrictive regulations." 239 The same commissioner obstructed the proposals for the production of rice, and the governor had to intervene. These obstructions had so much impact on Mackie that he was willing to transfer to a smaller colony on a smaller salary or work under someone else temporarily as a result of the war if he was deemed to be the problem. He was convinced, however, that he was not the problem, but it was the organization. He wrote, "But whatever may be my shortcomings I do feel that there is also something wrong with the system of Government which permits of such delays and obstruction and I am fortified in this opinion by discussions I have had with Administrative Officers in both Secretariats and in the Provinces, many of whom feel as I do." ${ }^{240}$ His feeling that Nigeria was not taking the war seriously, he argued, was shared by many Europeans who were in Nigeria and that the unnecessary red tape and paperwork that existed during peacetime was also continued during wartime even though there was a need for things to be done at a faster pace. Mackie's request was that

\footnotetext{
239 Ibid.

240 Ibid.
} 
immediate steps should be taken to review the organization and to put Nigeria on a war footing.

Sometime between the $29^{\text {th }}$ of May and the $18^{\text {th }}$ of June, Mackie had a meeting with the governor. We can only assume that the governor had a conversation with Mackie about the letter he sent to Hoskyns Abrahall. This assumption is based on the fact that on the $18^{\text {th }}$ of June, Mackie sent a circular to his officers in the agriculture department and he referenced a recent meeting with the governor. The governor informed him at the meeting that for the duration of the war, the primary work of the department should be the production of foodstuffs. He also said that the governor had assured him that his administration will assist them "in this work to the fullest possible extent."241 Feeling very optimistic about the support of the governor, Mackie in June gave his officers the free hand to carry out the work of expanding food production. He wrote, "I wish to give officers a very free hand and hope that everyone will use his own initiative. Each officer should formulate his own local proposals, discuss them with the Resident and then put them into effect. If however difficulties or obstructions are encountered I must be informed at once. The great thing is to get work done."242

Not only was Mackie motivated by the words of the governor, he was now motivating his officers to get work done. This was necessary at a time in which there was low morale in the department. Without the meeting with the governor, Mackie would not have had the confidence to give this directive to his officers. When he instructed them to

241 Memorandum on the Policy of the Agricultural Department, 18 June, 1940, Mackie Papers, RH: MSS. Afr. S. 823.

242 Ibid. 
report to him immediately should they encounter difficulties or obstructions, he was counting on the support of the governor to intervene. Mackie again in this memorandum reiterated the policy of the department that each province should be as self-supporting as possible and there cannot be over production of essential services. To commit his officers to what was the most essential of their duties, the production of more foodstuffs, he ended the policy in which the officers had to send in a monthly report. This was a bureaucratic step that took more time away from the officers' work. What the officers needed to submit monthly was the statement of expenditure. For the regular monthly report, they were no longer obliged to submit it. However, they were to keep him informed of their work progress and to report to him only when they have something important to report. ${ }^{243}$

Three days after Mackie sent the memorandum to his officers, he met with the CSG and he had a new demand. He wanted one man to be put in charge of food production to carry out any policy that was being decided by the governor. He expressed his willingness to serve under such a person but there is no doubt that Mackie would have been disappointed if such a position was created and he was not placed in charge of it. Later that same day, the governor met with Mackie and proposed to make him the Director of Food Production (DFP) in addition to his position as Director of Agriculture. Mackie's idea of this new position was different from that of the governor. Mackie wanted a position of authority but the governor had intended it to be just a title without any portfolio as a means of drawing attention to food production. When the governor

243 Ibid. 
communicated his intentions to Mackie, Mackie requested for more authority, and the governor told him he was going to discuss the position further with the CSG. Almost one year after Mackie was named to the position, the governor did not grant him any powers. In May of 1941, Mackie wrote to the CSG: "The duties of the post of Director of Food Production have never been defined and up to the present time I have never been asked for or been given any special powers. I have no authority to co-ordinate the food production work of the Agricultural Department with that of the Veterinary Department and schemes put forward by the Veterinary Department are still treated as if the latter was a completely watertight compartment." 244 The Governor had made clear to Mackie that he did not want to attach any powers to the position. It seems to me that telling him he was going to discuss with the CSG and get back to him was a simple way of ignoring him.

Mackie used this letter to the CSG to make a case for why powers should be granted to the DFP. He argued that the Conference of Directors of Agriculture in 1938 had stressed that you cannot separate supply from production and that each colony should appoint a Director of Food Production and Supply with ample funds at his disposal. ${ }^{245}$ Mackie continued: "If I am to carry out the functions of the Director of Food Production as envisaged by this Conference, and to make the effort required of us I must now ask for more staff; and more authority to co-ordinate the efforts of everyone engaged in the work of food production is essential if every available man is to pull his weight with the

\footnotetext{
${ }^{244}$ Mackie to CSG, 28 May, 1941, Mackie Papers, RH: MSS. Afr. S. 823.

245 Ibid.
} 
greatest possible effect." ${ }^{246}$ Mackie's proposal was to create some form of an amalgamation between the agriculture, veterinary and forestry departments. The CO had also been moving in this direction by expanding the Advisory Committee on Agriculture and Animal Health to include Forestry and then Fisheries. What Mackie was asking for made practical sense but it was politically toxic. It made practical sense because these departments would have been more effective if they coordinated their work. More often than not, these departments were always in conflict with each other. He was in fact asking for the heads of those departments to now be under his own authority. Perhaps if a neutral DFP was appointed and the directors of all three departments were under his control, his proposal may have had a fighting chance, but to bring the other departments somehow under his own control was too risky a move that neither the CSG nor the governor were prepared to make. What the CSG asked him to do was to submit what he considered to be the functions of the DFP. ${ }^{247}$ On the $10^{\text {th }}$ of June, 1941, Mackie wrote the CSG a confidential letter with a description of the functions of the DFP. Mackie suggested six duties of the Director of Food Production:

1. He was to be the sole channel through which all requirements for supplies would pass through.

2. He was to administer all funds meant for the development of production and allocate such funds to the department that would carry out the work.

3. He was to collaborate with the Food Controller on schemes that increased production and to authorize such schemes without subject to any other authority as long as those schemes conform to the policy of Government.

4. To co-ordinate the work of food production to make sure there is no waste or overlapping.

\footnotetext{
246 Ibid.

${ }^{247}$ Mackie references these instructions from the CSG in his letter to the CSG on $10^{\text {th }}$ June, 1941 outlining the duties of the DFP.
} 
5. To locate work where it is of most permanent value for the country.

6. To see to a smooth flow of supplies. ${ }^{248}$

On the $21^{\text {st }}$ of June, 1941, the governor directed the CSG to circulate a document defining the duties of the DFP. Mackie's suggestions were almost accepted verbatim. Even most of the language was maintained in the circular. Instead of six duties, only four where stated in the circular. The sixth duty in Mackie's letter was combined with the fourth. What was conspicuously absent was the first duty that Mackie stated in his letter. The governor did not grant that authority to him. In my view, the reason is because he wanted the respective departments to still maintain some level of independence and authority. This factor was very important to the governor and he made it clear at the end of the circular that the DFP was not going to interfere with the normal duties of the departments. The circular said, "His Excellency wishes it clearly to be understood that this definition of the Director of Food Production's duties in no way implies any interference with the normal functions of Departments but is directed solely to ensure that development should not be hampered by administrative delays and that the limited staff of qualified officers available may be employed to the greatest effect." ${ }^{249}$ The DFP had no authority to assign the different officers of the technical departments. That was the responsibility of the director of their department. If the DFP needed a technical officer for any specific purpose, he had to arrange it with that department head and the CSG. The governor's approach was a middle way toward dealing with what could have been a potential disaster. In one way, Mackie got what he wanted and in another way, the other

\footnotetext{
248 Mackie to CSG, 10 June, 1941, Mackie Papers, RH: MSS. Afr. S. 823.

${ }^{249}$ Circular by CSG, 21 June, 1941, Mackie Papers, RH: MSS. Afr. S. 823.
} 
department heads maintained authority over their departments. If you look closely at the defined duties that the governor gave Mackie as the DFP, the position could be aptly described as a "toothless bulldog." Most of those duties were those he was already carrying out as the director of the agriculture department.

What is important is that Mackie was satisfied with his new position and he felt he was making a difference in food production. What continued to be a major problem to the execution of his work was the dearth of staff. In order to increase production, he needed agricultural staff to help him in this work. This he believed was not only urgently needed during wartime but also for the post-war period. The agricultural staff helped with the supervision of the African farmers. He argued that increased production could only be achieved through three principal means: stimulating the African farmer to put forth more efforts; using Europeans to develop more government estates; and allowing firms to develop estates. ${ }^{250}$ In the case of Nigeria, the first option was the best. Peasant cultivation had been the staple of Nigeria's economy. Mackie did not think that it was good policy to divert European staff to government estate development when peasant production had not reached its peak. There were vast areas that still needed an agricultural officer and there wasn't any to provide. Allowing firms to develop estates was one means that he did not want to consider because it was a controversial one. Unlike some other British colonies in Africa like Kenya, Nigeria did not have private estate production. In the early years of colonization, this option was resisted and part of the reason was because of the Nigerian system of land tenure. ${ }^{251}$ When Lever Brothers, a British firm wanted peasant land to be

\footnotetext{
250 Mackie to CSG, 18 April, 1942, Mackie Papers, RH: MSS. Afr. S. 823.

251 See Anne Philips, The Enigma of Colonialism, 59-79.
} 
appropriated to the company for plantation agriculture, Governor Hugh Clifford responded by addressing the Nigerian Council in 1920, telling them that,

... agricultural industries in tropical countries which are mainly, or exclusively, in the hands of the native peasantry a) have a firmer root than similar enterprises when owned and managed by Europeans, because they are natural growths, not artificial creations, and are self-supporting, as regards labour, while European plantations can only be maintained by some system of organised immigration or by some form of compulsory labour; b) are incomparably the cheapest instruments for the production of agricultural produce on a large scale that have yet been devised; and c) are capable of a rapidity of expansion and a progressive increase of output that beggar every record of the past, and altogether unparalleled in all the long history of European enterprises in the tropics. ${ }^{252}$

Though Clifford's argument claims that the reason for denying the introduction of plantation agriculture is the productive character of peasant agriculture, the ultimate reason was the controversy over land and labor that plantation agriculture was going to create and this was bound to wrestle the authority upon which the colonial state rested. ${ }^{253}$ Mackie had not foreclosed on the idea of developing government estates in the near future. His thinking around such estates was for the post-war period. He felt that such estates could be parceled out to some of the returning soldiers to cultivate under the supervision of a European agricultural officer. He wrote, "I should like to see for several of these estates started before the war ends both in the N.Ps and the S.Ps., for even if they are planted up with permanent crops which take several years to grow into bearing I am sure that there will be a demand for our produce for several years after the war ends." 254

\footnotetext{
252 Hugh Clifford, Address to the Nigerian Council, 29 December, 1920 (Lagos: Government Printer, 1920), 186.

253 See Dan Mou, State Power, Agrarian Policies and Peasant Welfare: Politics of Agricultural Marketing and Commodity Boards in Nigeria (Bloomington: AuthorHouse, 2014), 168.

254 Mackie to CSG, 18 April, 1942, Mackie Papers, RH: MSS. Afr. S. 823.
} 
With all of this, what Mackie needed to execute his task of increasing production was more agricultural staff. These were not forthcoming from the $\mathrm{CO}$ even though the demand was made. Mackie's assumption was that he was not getting these staff because the $\mathrm{CO}$ did not value the potential of Nigerian agriculture. I do not think he was correct in such thinking. This was a time of war and a time of extraordinary difficulties. Most of the young men had entered the military and it was not only Nigeria that was vitally important to the empire in terms of production, but other colonies as well. Yes, Nigeria was a big colony with agricultural potential but it did not have a monopoly to all production. Agricultural officers had to be shared with other colonies as well. What however is important is the passion Mackie had for the development of agriculture in Nigeria and how he desperately wanted the Nigerian colony to make significant contributions to the war through her produce. Mackie's work during this period was very important to the development plan. Some of the ideas he developed at this time became the bedrock of the 1945 agricultural plan of development.

\section{Reorganizing the Departments}

As stated above, the policies that Mackie developed in the period shortly before the war and the agricultural plan to expand production he drafted during that time was instrumental to the 1945 plan that was submitted to the CO. When Mackie submitted this earlier plan, he did not hear back from the CO. He felt that his plan was being ignored. As the CO requested a more detailed agricultural plan from Nigeria in 1944, Governor 
Arthur Richards ${ }^{255}$ invited Mackie and the other two directors of the departments of forestry and veterinary service to a meeting at the Government House in Lagos in December of 1944. The meeting was to help them coordinate development policy and to aid them toward working together in areas where their work overlapped. There was friction between these three departments and it ended up affecting the work of the departments. Mackie along with the director of veterinary services and the chief conservator of forests accepted the invitation to the meeting and were in attendance. Other persons in attendance were the governor, the acting chief secretary, the chief commissioners of the Eastern, Northern and Western provinces; the development secretary, and the acting deputy chief secretary. At the meeting, the governor announced a new structure that he felt would enable the three departments to work well together. The governor was moving toward greater centralization. The offices of the heads of these departments were moved from their respective locations to Lagos and their new responsibility was that of serving as advisers to the Nigerian central government. New deputies were appointed to head these department heads and were given offices at the locations where the directors previously had their main offices. The deputy for the

\footnotetext{
255 Before his appointment to Nigeria as governor in 1943, Sir Arthur Richards had served as governor of Jamaica, 1938-43; governor of Fiji and High Commissioner of the Western Pacific, 193638; governor of Gambia, 1933-36, governor of North Borneo, 1930-33. He had varied experiences and was considered the right fit to deal with the political quagmire that Nigeria was facing after Sir Bernard Boudilion divided Nigeria into three regions: Northern, Eastern and Western. Sir Bernard was in doubt of his decision after the changes because he believed he had insulated the north from the rest of Nigeria. He could not find a solution to the problem before he retired in 1943. When Richards was appointed governor, he rushed through constitutional reforms to institute the three regions. From the way Richards rushed the reforms immediately he was instituted as Nigerian governor, it is possible that his appointment came with that mandate but I have no archival evidence to support this view. He was severely criticized by the nationalist movements for the constitution. For more on the Richard's constitution, see Kalu Ezera, Constitutional Developments in Nigeria: An Analytical Study of Nigeria's Constitution-Making Developments and the Historical and Political Factors that affected Constitutional Change (Cambridge: Cambridge University Press, 1960), 64-81; Eme 0. Awa, Federal Government in Nigeria (Berkeley: University of California Press, 1964).
} 
Northern Province had an office in Kaduna, the deputy for the Southern Province had an office in Enugu and the deputy for the Western Province had an office in Ibadan. The governor also considered appointing a fourth deputy for each of the departments who would be located in Lagos. The aim was to free the department heads to travel more around the country. The deputies who were assigned to the different provinces were to be advisers to the chief commissioners. The governor believed that these deputies had to be in a position in which they could give authoritative advice to the chief commissioners without reference to the department heads. The deputies were to be "subject to the orders of the Chief Commissioners in all Administrative matters relating to their Departments, but Chief Commissioners would not of course, be in a position to give directions on technical matters. On such matters the Deputies should seek directions from their Head of Department in Lagos." 256 The authority to post officers to these departments also was to emanate from the secretariat. By giving control of staff appointments to the secretariat, as well as subjecting the deputies to the control of the chief commissioners was an attempt to weaken the technical departments, while at the same time strengthening the political administration. The governor believed that the overlapping and the frictions between the three departments was a result of the three heads of departments working in isolated locations from each other and from the secretariat in Lagos. His belief was that by putting them in one location, this problem was going to be solved. The authority to discipline departmental officers was now bestowed on the chief commissioners and if necessary,

\footnotetext{
${ }^{256}$ Minutes of a Meeting held at Government House, 8 January, 1945, Mackie Papers, RH: MSS. Afr. S. 823.
} 
referred to the secretariat in Lagos. ${ }^{257}$ This reorganization, which was advanced by the governor, gave victory to the political officials. This change instituted by Richards was detrimental to development policy that was based on scientific research and advice.

As shown earlier in this chapter, there was always a tension between the technical department staff and the political officials in the provinces and districts. The political officers felt that the staff of the technical departments worked under them. Conversely, the staff of the technical departments wanted to have more autonomy from the political officers in carrying out their work. The governor, in this meeting, clearly defined the authority. Not only were the technical staff to take their orders in the provinces from the chief commissioners, but they were also to be disciplined by them. While Mackie spent several years pushing for more authority and independence, now he was even stripped of the authority that he had. He could no longer assign his officers and he now was imposed with deputies that were not even reporting to him. These deputies reported to the chief commissioners and only referenced him in technical matters. It is not surprising that this did not go well with Mackie. While the other two heads of departments accepted what the governor said, Mackie protested. He said that he did not like the idea of surrendering his personal authority to post his staff to the secretariat. The governor's response to him was that, "while the views of the head of any Department would be taken the final exercising of authority would of necessity have to be done centrally, and in some cases there was clearly need for the exercising of some control over the postings made by the Heads of Departments. ${ }^{258}$ This was a big change for the heads of departments who exercised

\footnotetext{
257 Ibid.

258 Ibid.
} 
authority in posting their staff. Mackie insisted that he would have to "resist interference with his executive control over the officers of his Department." The governor insisted that neither he nor any head of department could be regarded as having complete command. They would have to rely on his directions. ${ }^{259}$ The governor's direction toward centralization was bound to affect development policy. The most effective structure in development is a decentralized approach because planners would have better knowledge of local conditions and take them into account. What the governor was doing was taking the authority of the agricultural officers and placing it in the hands of officers who had no experience or knowledge of agriculture. The effect of this was that the process was going to be less responsive to the local needs and problems of the people.

Over many years the different departments had acquired much power and independence and they had also wrestled with each other for more authority thereby leading to tensions. The administrative officials had always wanted to rein in the powers of the department heads and bring the department heads into their own control. One of the reasons some of the Residents were not giving access to the technical staff was because they believed that the departments were running their own schemes and projects irrespective of the traditional administrations. Yet, the Residents did not want the technical staff to have direct access to the African leaders. Such access must always come through the Resident or the provincial commissioners. Governor Richards believed that the heads of departments caused these tensions. His way of resolving these tensions was to bring them under the central secretariat and strip them of their executive powers

259 Ibid. 
leaving them with only limited technical powers. Their technical powers were limited because they did not have the authority to even advise directly the chief commissioners. They were now simply advisers to the central government. Most schemes and projects took place at the provincial and district levels and not at the central level. One can argue rightly that there was a "palace coup" against them. I believe that this new policy was directed mostly at Mackie. He seemed to be more aggressive in his quest for more control. The other two department heads accepted what the governor said without any protest. Mackie knew there was a coup against him and if anyone had followed his life closely in Nigeria, they would have known that his days in Nigeria, from that moment, were numbered.

At this meeting, the development secretary asked that "something definite should be stated at the meeting in regard to the preparation of development proposals, and asked that the governor might rule the latest date at which these proposals should be furnished, as well as a statement of suggested policy for each of the three Departments represented at the meeting. ${ }^{260}$ Mackie said at the meeting that he would have his statement of policy and proposals ready no later than the end of January. The other two heads of departments agreed that they would also have theirs ready. The governor ruled that their development proposals should be completed and ready by the end of January. ${ }^{261}$

\footnotetext{
260 Ibid.

261 Ibid.
} 


\section{The Agricultural Plan}

The dysfunctional relationship between the department of agriculture, veterinary services and forestry was part of the reason that the plans of these departments were not ready in 1944. The poor relationship between the agriculture department and political officials also contributed to the delay. As mentioned earlier in this chapter, Mackie had submitted a ten-year agricultural plan four years prior to this time. In his view, this plan was ignored and forgotten entirely. One wonders why Mackie was not asked to revise this plan and have it approved by the CO together with the other plans in 1945. In any event, Mackie submitted six copies of his development proposals to the secretariat on the $30^{\text {th }}$ of January 1945 and he requested that one of the copies be sent directly as it stood to the $\mathrm{S}$ of $\mathrm{S}$. Though the proposals were drawn up for a period of ten years, Mackie did not believe that they could be implemented within that time frame because there wouldn't be adequate staff to fully implement the proposals. For this reason, he saw the proposals as "one proposal which is to expand the Agricultural Department sufficiently to provide Nigeria with Agricultural services which are adequate for the needs of the country, bearing in mind that Nigeria is and will always remain an Agricultural country." 262 This view by Mackie that the Nigerian productive force would always be agriculture was the agricultural bias that pervaded the colonial state. If only Mackie could have foreseen that by the 1970 s Nigeria would move from being an agricultural country to an oil-producing country. However, Mackie was right that Nigeria at the time was an agricultural country, and I believe it is still an agricultural country. The majority of the people in Nigeria still

\footnotetext{
262 Mackie to CSG, Proposals for the expansion of Nigerian Agriculture, 30 January, 1945, Mackie Papers, RH: MSS. Afr. S. 823.
} 
rely on agriculture for survival. Though Nigeria's economy is now based on the export of crude oil, Nigerian farmed agricultural products remain a staple of internal trade. Apart from poultry, only rice is a staple that is imported into the country at a commercial rate. A good quantity of rice consumed in the country is also locally grown. The maize, yams, cassava, plantains, etc. which are staples on Nigerian dining tables are grown locally. These are not usually cultivated by big industrial farms but by peasant farmers. Despite the oil revenues, agriculture remains the sector that provides the most economic empowerment to the majority of Nigerians. A majority of Nigerians live in rural areas and depend on peasant farming for their livelihood. From what they produce, they feed their families and sell some to gain purchasing power. In a sense, Mackie's vision of a strong agricultural service that would be adequate for the needs of Nigeria in the present and in the future was correct. Nigeria today, as in the colonial times, has been to a large extent self-sufficient in food. What has plagued Nigeria is in its ability to produce agricultural products for exports.

More specifically, the agricultural plan that was submitted was divided into five sections: general agriculture including agricultural research, marketing and produce inspection, agricultural training, irrigation and oil palm research. I will analyze each of these sections. The estimated cost of the plan was $£ 12,184,000$ over the ten-year period. Mackie thought because they wouldn't have the staff necessary to implement the whole plan within the ten-year period, it should for all practical purposes be considered a fifteen year plan. He believed that the estimated amount that would be spent in the ten-year 
period of the plan would be $£ 8,000000 .{ }^{263}$ In estimating his plan, Mackie was afraid that the financial demand they were making for agriculture was too large. He even indicated that his plan might be criticized for being too excessive. He was being cautious when he indicated that $£ 8$ million might be enough for the ten-year period. If one should follow his logic that Nigeria was an agriculture country and would always be one, more investment in agriculture should have been expected. The Nigerian development plan was estimated at about $£ 55$ million. The estimates given by Mackie were only about $20 \%$ of the cost of the development plan. Given the importance of agriculture not only to the economic empowerment of the country and its potential to better the standard of lives of the people, agriculture should have been expected to receive more investments. But in light of the hostility that the department faced from the political authorities, it would have been surprising if agriculture would have received more.

The first section of the plan was on agricultural policy in Nigeria. This section begins with the definition of agricultural development. It stated: "Agricultural Development is not a series of schemes it is a question of continuous research and sound extension work. There is nothing else to it." ${ }^{264}$ This apt definition of agricultural development laid the foundation for the plan. For many years, the view of agricultural development was a proliferation of many schemes. The provincial and district officials carried a series of schemes. Often, these schemes were carried out without making use of all the technical resources available through the agricultural department because of the tensions that existed. These schemes had a high failure rate. The proposed plan envisaged

\footnotetext{
263 Ibid.

264 Ibid.
} 
a more coordinated effort that would bring together research and extension work. Mackie together with the department of agriculture, was a big advocate of agricultural research. For him, the department should have spent several years studying any crop or system of farming before the African farmer was asked to adopt it.

Why this was important was that a series of failed local schemes meant that farmers were going to lose confidence in the colonial state. Failed crops had severe consequences for the peasant farmer. As I have stated earlier in this chapter, one of the biggest handicaps for the peasant farmer was labor. If a peasant farmer, who had been cultivating maize, was introduced and encouraged to cultivate rice, and if he decided to adopt rice as crop, it meant he had to reduce significantly the amount of maize he cultivated or eliminate cultivating maize altogether. If rice had not been carefully researched and studied over time to be sure that it would produce well in the region and it failed, this would leave the farmer in severe circumstances. He had neither capital nor reserves to rely on. There was always the problem of risk aversion for the farmer. Farmers underwent such difficult circumstances during droughts and were reluctant to invite such circumstances upon themselves with the introduction of new crops. Careful research was necessary in order to gain the people's confidence. Mackie writes, "From the time when an Agricultural Officer is first posted to a new area it is usually at least 10 years before he can make any appreciable progress with extension work, but after that steady progress can usually be recorded." 265 It took that much time because the officer had to gain the farmer's confidence through his own demonstration farms. Mackie

265 Ibid. 
insisted that for the agricultural policy of his department to be well carried out well, every member of the agricultural department "must himself be a farmer, and he must be able to farm as well as or better than the people of the district in which he is working." He continued, "It cannot be too strongly stressed that the main and perhaps only function of an Agricultural Department is to teach the people how to farm better than they do at present. It is therefore essential that the Department should actually farm a considerable area of land, and that our farms in addition to being research stations should also be used for the training in farming of both European and African staff.,"266

The assumption was that if you were an agriculture officer, you know how to farm. Mackie, from his several years of experience in the agriculture department, knew that this was not always the case. It is possible to know the theory without actually knowing the practical. Rather than standing and telling people what to do, Mackie wanted agricultural officers to be hands on the job. They needed to know how to farm and not only how to farm but also to be better farmers than the people that they were working with. This is important because it was a means of convincing the people to take their advice and to adopt their own methods of cultivation. Mackie wanted to be sure that before the native form of cultivation was changed, the methods proposed by the department had been thoroughly tested and found to be superior to the methods used by the locals. He wrote, "We are therefore learning to farm under all possible conditions and the more we study the question the more we become convinced that it is extremely unwise to try and change native systems of Agriculture until we are sure that the change

266 Ibid. 
is sound from the point of view of the native farmer under his own local conditions." ${ }^{267}$ What Mackie was proposing was not always the case in Nigeria or in most British dependencies in Africa. The African farmer was frequently looked upon as inferior and without any sound knowledge of cultivation. The colonial officer imposed a new method of cultivation on them without taking into consideration the local conditions and this often led to disaster causing the colonial official to lose credibility. For Mackie, credibility was an important aspect of extension work and there was no better way of gaining this credibility than by showing the African farmer that you are a better farmer than him. Mackie wrote, "The African farmer is generally a capable Agriculturalist within the limits of his own environment and tools and if we try to force him to do something which he knows is unsound we merely lose both his confidence and respect." ${ }^{268}$ Peasant agriculture communities in Nigeria afford great respect and authority as excellent farmers. The agriculture officer can gain this respect and authority by showing his excellence in farming. This takes several years.

Another important aspect to agriculture policy in Nigeria was the training of African staff. Mackie's policy placed great importance on using more African staff in the department. The departmental school in Ibadan had been training African staff since 1921 and the one in Samaru since 1928, and these staff were considered crucial to the success of the department's work. Mackie's proposal was that the Ibadan school should be expanded to award degrees in agriculture to African staff and he also looked forward to when women would be trained as agricultural assistants. He wrote, "It is now generally

\footnotetext{
267 Ibid.

268 Ibid.
} 
agreed in the Department that to enable a European Officer to be of maximum value to the country he should have an African staff of up to 20 trained people working under him. The fully trained African Assistant has undoubtedly been a success and I am now quite satisfied that there is scope for African Agricultural Officers." ${ }^{269}$ What he meant was that Africans should be trained to be district officers and not just assistants. He was proposing that African staff should also be trained so that they would no longer be just assistants to the European agricultural officers but could also be agricultural officers in their own right. If this plan was implemented, it was going to bring about two important benefits: it would help resolve the perennial problem of Nigerian agriculture which was the dearth of agricultural officers and it would also be more financially economical to have African staff in those positions than European staff. For Mackie, African staff trained with degrees in Ibadan could go to Trinidad for advanced training in tropical agriculture. $^{270}$

Another big part of the agricultural development proposals was the reorganization of the department. Mackie's proposal took into consideration the decision of the governor to move the director of the department to Lagos and also to appoint deputies for each of the provinces. The director would also have a senior deputy director, a secretary and a statistician working with him at the secretariat. The idea of having these additional staff was to enable the director to travel more in order to give sound advice to the governor. Mackie's organization of the department was geared towards ensuring that every part of

\footnotetext{
269 Ibid.

270 The Imperial College of Tropical Agriculture in Trinidad was founded in 1921 to provide postgraduate training in tropical agriculture for the agricultural services of the colonial empire. Most of the graduates of the school were appointed to different agriculture departments. Upon leaving Nigeria, Faulkner was appointed Principal of the school in 1938.
} 
the country was covered adequately with agricultural services. His goal was to provide each agriculture officer with twenty trained Africans. He also understood that this was not going to be possible in the ten-year period of the plan. He insisted that no position was to be reserved for Europeans only. The reason for this was that he had the plan to have Africans trained as agricultural offices and he believed that sooner or later many qualified Africans would be available to assume these positions. Mackie was more forward thinking than most of his peers, breaking down the racial ideologies that Europeans were more capable than Africans. He believed that Africans would be able to assume the same positions in the department that were being held by Europeans. This attitude was one in which the African staff saw clearly and stated in their farewell speech to him when he retired from the service in Nigeria. Their words that no one else in the department had worked harder to advance the welfare of the African staff were words borne of their experiences with him. ${ }^{271}$

Mackie's agricultural proposal called for each deputy director to have a team of specialist staff, experimental farms, a stock-farm and eventually a school where assistant officers would be trained. Each province was also to have a team of agricultural officers. ${ }^{272}$ This was in line with the plan to have everything well researched before the African farmers were asked to adopt it. Nigeria was a place with varied climatic conditions and topography. The expert team working with the deputy director would help research and investigate crops and methods that would be suitable for the area. In the case

\footnotetext{
271 A Valedictory Address Presented by the Entire Staff, agricultural department, Nigeria, on the retirement of James Mackie, 16 February, 1945, Mackie Papers, RH: MSS. Afr. S. 823.

272 Mackie to CSG, Proposals for the expansion of Nigerian Agriculture, 30 January, 1945, Mackie Papers, RH: MSS. Afr. S. 823.
} 
of Nigeria, the approach was not going to be a one size fits all. The team of experts working with the deputy director were to include botanists, a pasture research chemist, entomologists, an engineer, an economist, experts in dairy, poultry, and pasture research; a geneticist, a mycologist and an horticulturist. Mackie did not include soil conservation officers even though Dr. Tempany had criticized him for this. Mackie's argument was that he did not like the term because he felt that "every Agricultural Officer and Forestry Officer is a soil conservation Officer and they should never be allowed to forget it. To apply this title to special officers is to give the impression to the others that soil conservation is not their business. ${ }^{273}$ While the other experts included in his list were all directly related in some way to agricultural cultivation, he included an economist in this list of experts who were to work with the deputy director. One may wonder about the importance of an economist to rural agricultural development. If there was a need for an economist, shouldn't such an economist be working at the central secretariat? Mackie's plan called for a statistician working with the director of agriculture in the central secretariat to help him with crunching data. At the provincial level, what he felt was needed was an economist. The role of the economist was to closely study the economics of peasant farming. He wrote, "farming after all is economics - and the Nigerian farmer is an economist. ${ }^{, 274}$ Having the economists at the local level helped with collecting data on the economics of peasant farming and also to be able to access the economic contribution that women made in peasant farming. It was very easy to see what contributions the men made because they were the ones who were regarded as the

\footnotetext{
273 Ibid.

274 Ibid.
} 
farmers. Women made enormous contributions through their labor. They cooked meals for those who worked in the farms, they helped with watering crops where irrigation was not present and they also were the ones who did the weeding after the crops had been planted. The peasant farmer, in choosing what crop to plant and what quantity to cultivate, had to make an economic decision. This deserved study if native agriculture was to be successfully expanded to better the economic lives of the people and the economy of the colony.

True to his definition of agricultural development as being research and extension, his plan, rather than focusing on developing big agricultural schemes, concentrated on research/investigation and extension work. His idea was to have a strong research and investigation center in each of the provinces and then extend the success of that labor to the local farmers. The temptation in this late colonial period by some officials was to be engaged in schemes that would guarantee quick returns and this we will see in the next chapter when one of such schemes in Nigeria is discussed. Mackie understood that to have a solid agricultural development project, it was going to take time and he saw no need to rush through the process. He wanted there to be a solid foundation in research and investigation. His plan encapsulates this principle. In the western province, there was already the main research station, which was at Moor Plantation. This station was equipped for both laboratory and field investigations. The area also had a stock farm that was established in 1932 at Illorin. This stock farm was researching the breading of cattle that would be resistant to trypanosomiasis. ${ }^{275} \mathrm{He}$ proposed in the plan for a breeding farm

\footnotetext{
275 This was a disease transmitted by tsetse flies. This disease is also called nagana and when cattle were infected with it, it could be fatal because it caused weakness, fever, anemia, and lethargy. If
} 
to produce animals for distribution. At the time of drafting the plan, there was a farm school in Oyo that was still operating on an experimental basis. If this farm became successful, he proposed that many other farm schools should be established. While Mackie's plan is commendable in its emphasis on studying and researching the problem, this had a weakness of not doing much in terms of practice. At a time when what the country needed was immediate relief, his plan's insistence on research meant things would be going slowly.

Significantly, his plan did not call for the mechanization of cultivation, in contrast to the kind of schemes we will discuss in the next chapter. The reason is because he believed such initiatives would never be successful in southern Nigeria, and he felt that they would spell disaster. They could only be successful, he argued, if they are "accompanied by a sound system of manuring and soil conservation, for their use involves the complete stumping of large areas." ${ }^{276} \mathrm{He}$ was very weary of using tractors because he believed they caused erosion. Beyond the problem of erosion there was also the cost and the problem of spare parts. The Mokwa agricultural development experiment that we will analyze in the next chapter exemplifies these problems. Mackie's plan called for the trial of one large-scale government plantation in the western province based on cocoa, citrus and white kola. His plan did not provide details on the size of such plantations nor did it cost it.

mixed farming was going to be successful, it was important that cattle used should be resistant to the parasite that caused this disease.

276 Mackie to CSG, Proposals for the expansion of Nigerian Agriculture, 30 January, 1945, Mackie

Papers, RH: MSS. Afr. S. 823. 
Unlike the western provinces, Mackie acknowledged that in the eastern provinces agricultural organization was not as advanced. The main agricultural product from this province was palm fruit. These grew wildly in the forests, unlike in the western provinces where farmers had adopted the planting of cocoa or in the northern provinces were nuts and seed were planted by the farmers. In the eastern provinces, there were no specialist officers and no testing laboratories. There were, however, experimental stations in Umuahia, Nkwale, Bamenda, Yandev, and in Esosong. It is important to note that Esoson and Bamenda were in Southern Cameroons and this area was part of the eastern provinces. In this province, Mackie felt that the first essential thing to do toward agricultural development was research and experimentation. He wanted to establish a central research station on the lines of Moor Plantation in this region. This station was to be provided with laboratories, housing accommodations, buildings, water supply, etc. The plan did not identify the location of a station as no decision had been made. His next proposal for the region was a stock farm that would deal with "the improvement and management of all kinds of stock including poultry." 277 Serious research in the eastern provinces was important because one of the fundamental problems in the region was that of soil fertility.

In his organization, he divided the northern provinces into the western area and the eastern area. Samaru was the headquarters of the agricultural department in the northern province. Like the western provinces, it had a research station, and several studies had been carried out there on soil fertility and mixed farming. He proposed to

277 Ibid. 
establish new school buildings in Samaru and also to increase office, laboratory and housing accommodations. He also proposed to develop irrigation, establish farm schools in the provinces and have a settlement scheme for ex-soldiers. Mackie's proposal in this area was the testing of agricultural machinery and artificial manures. While he did not support machinery in the western province, he was in support of machinery in the northern provinces. The difference is that the northern provinces did not have as much rains as the western provinces and thus erosion and the problem of soil losing nitrogen was not as serious in this region as in the western provinces. The eastern part of the northern provinces also suffered the same problems that the eastern provinces of Nigeria faced. There was a lack of agricultural services there. There were no facilities for research in the area. His plan called for the establishment of a headquarters for the assistant director of agriculture and his specialist staff. He also wanted a central research station, on the lines of the one proposed for the eastern provinces of Nigeria, to be built. Such a center was estimated to cost $£ 100,000$. He proposed the establishment of an experimental farm in Maiduguri and also the establishment of a school for training of traditional administration and other junior staff.

When you look at the details of his agricultural plan discussed above, it is clearly skewed toward research. His plan also devoted a whole section to oil palm research and he made a case for it. One does not see big agricultural schemes in his plan. He was biased toward research and extension work which he saw as key to agricultural development in a peasant economy. He believed that if this was done in Nigeria, then Nigeria would have a strong economic footing. As stated earlier, this plan was a revision 
of his 1940 plan and he kept much of the language of the old plan. As you read the plan, you gain the impression that Mackie had all the intentions to carefully nurture this plan to full implementation. The temptation is to assume that Mackie would be in Nigeria in 1955 or even 1960 as the director of agriculture to see the successful implementation of this plan. But that was not the case. A few days after his submission of the plan on $30^{\text {th }}$ of January 1945, he resigned from his service in Nigeria and moved back to Britain. His personal correspondences upon the occasion of his retirement showed that he was frustrated with his service in Nigeria and he knew that he would not have the freedom to implement this plan, which he had drawn up. In one personal handwritten letter to a friend, he stated the reasons for resigning. He said the governor made it quite clear that his departure from Nigeria was going to be welcomed by him. His second reason was that he did not think systematic agricultural development was possible under the present circumstances, a situation which the technical department was weakened by being stripped of authority and subjected to the political officials. He couldn't agree that the director of agriculture should lose his executive authority and that his agricultural officers should be taking instructions from administrative officers rather than from him. ${ }^{278}$ What this means to him was that the agricultural service was a subordinate service. He also felt that the Nigerian government was running a kind of dictatorship. The technical advisers were no longer consulted and they were not allowed to make public their plans. Another reason he gave were attempts to make him a subordinate to the director of supplies the previous year, and he was at the moment made a subordinate to a second rate member of his own service. He said all the main proposals of his predecessor, Faulkner, and his own

\footnotetext{
${ }^{278}$ First page of letter with receiver and date missing. Mackie Papers, RH: MSS. Afr. S. 823.
} 
main proposals of the past twenty years had been restructured by the administration. At the end of his letter, he wrote, "I and my staff have reached the conclusion that the chief concern of the Govt is to make Nigeria safe for Admin Dept. and Agric. Development is merely a sideline. Naaja Lagos is rapidly becoming a public scandal and a job hunters paradise. This is fully realised by the Africans. ${ }^{279}$ His perceived marginalization of the agriculture department meant that the government was against development. This is a contradiction because the $\mathrm{CO}$ had already set in motion a plan for development and change, which the Nigerian colonial state took seriously and was working toward. At issue was a clash of power and visions of development. The political administration wanted more control and centralization but Mackie wanted more control and a decentralized approach.

Though Mackie's plan became the agricultural plan for Nigeria, he never received any public acknowledgement by the colonial government in Nigeria for his work in drafting the plan. So, on the $17^{\text {th }}$ of April 1946, he wrote to the S of S protesting that his contribution to the plan was not acknowledged. ${ }^{280}$ The $\mathrm{S}$ of $\mathrm{S}$ made enquiries to Governor Richards. In his response, Richards acknowledged that Mackie's contribution to the plan was considerable. However, he said as the governor he had to take full responsibility for the plan. He continued, "The recognition that the various sections of the Plan had been prepared by the officers named in no way implied that those Heads of Departments were solely responsible for formulating the plans outlined therein." ${ }^{281}$ The governor also argued that it was only possible for the heads of departments to quickly prepare the Ten

279 Ibid.

280 Mackie to Hall, 17 April, 1946, Mackie Papers, RH: MSS. Afr. S. 823.

281 Richards to Hall, 4 September, 1946, Mackie Papers, RH: Afr. S. 823. 
Year Plan of Development because of the work that had been done to a large extent by the previous heads of departments. He concluded, "Mr. Mackie is by no means the only former Head of Department who has contributed to the proposals made in the Sessional Paper, a great many both past and present officers have made valuable contributions. It was not, however, considered fitting that acknowledgement of these contributions should be included in a document of this nature."282

With or without any public acknowledgement, Mackie was by far the most influential person in Nigerian agriculture in the late colonial period and the $\mathrm{CO}$ was aware of his contributions. When Mackie's plan was up for discussion in the CO, Dr. Tempany said, "I would like to say that Capt. Mackie's plan represents the outcome of an enormous amount of work spread over 5 years. When I was in Nigeria I had the opportunity of discussing in great detail the earlier forms of the plan....I have nothing but praise for this memorandum. I think that in its preparation Capt. Mackie has rendered a signal service to Nigeria, and after studying it with care I can find no points in it with which I am in serious disagreement." ${ }^{283}$ Mackie was a visionary and set the department on a path that if it had followed, would have avoided some of the mistakes that happened after 1945 in Nigerian agriculture, such as NAP which will be examined in the next chapter.

\footnotetext{
282 Ibid.

283 Planning \& Reorganization of Agriculture, Minute by Dr. Tempany, 30 June, 1946, TNA: C0583/272/3.
} 


\section{Conclusion}

By looking at agricultural policy and planning in Nigeria through the lens of the director of agriculture and his relationship with the administrative officials in Nigeria, this chapter reveals the contradictions and tensions that existed between the two arms of the colonial state: the administrative arm and the technical arm. The study shows that this fractious relationship affected the successful planning of agricultural development in Nigeria. In this battle between the technical department and the administrative department in Nigeria, the administrative department won.

Agriculture was the foundation of the Nigerian economy and the success of the 1945 plan depended to a large extent on the success of agriculture. This was the main reason that Nigerian officials wanted to frontload resources in the early years of the plan's implementation. The idea was that if agricultural production is strengthened and expanded, then there would be resources beyond the ten years to continue to support development in Nigeria. As was laid out in the first chapter, some scholars do not see the 1945 plan as truly a plan but an amalgam of schemes. An analysis of the agriculture plan shows that this was a well-thought out plan that was based on several years of agricultural policy in Nigeria. Though this plan had some practical schemes, it was however based on a core philosophy that had guided the development of agriculture: research, experimentation and extension. These three were the anchors of the agricultural department during the years of Faulkner and Mackie. This tripartite approach led to the success of green manuring in western Nigeria and mixed farming in northern Nigeria. This chapter also shows that the agriculture plan was focused on replicating the successes 
of the western and northern parts of Nigeria in the south-eastern parts where there were no serious research and extension work going on.

At the time that the Legislative Council passed the 1945 plan, most of the agriculture schemes had not been approved and a substantial sum in the agriculture plan was identified as "other charges." This was because the agriculture department in Nigeria was cautious in advancing schemes without first researching and experimenting them and then having the necessary human resources to extend those services to the farmers. By 1947 when the Labour Government was in power in London and it was also the height of the Sterling Crisis, there was a shift in agricultural policy in Nigeria. The agriculture policy, which up until this moment focused a lot on research and careful trials, was abandoned. One major consequence of this shift was the catastrophic failure of NAP which we will see in the next chapter. NAP did not go through careful research and field trials and it became a very expensive social experiment in modern agriculture. 


\section{CHAPTER FOUR}

\section{PLANNING AGRICULTURAL DEVELOPMENT: A CASE STUDY OF THE NIGER AGRICULTURAL DEVELOPMENT PROJECT, MOKWA}

\section{Introduction}

During the Second World War, James Mackie argued that there was a need for agricultural production to be expanded, as this was necessary not only as a wartime measure but also for the postwar period. In the last chapter, I discussed Mackie's proposals for the expansion of Nigerian agriculture which he believed was essential not only for the colony itself but for the empire. Mackie retired from the Nigerian service after submitting his agricultural development plan. Did any shift occur in Nigerian agriculture after the departure of Mackie? In this chapter, I attempt to answer this question by using as a case study, the Niger Agriculture Development Project, Mokwa (NAP). This scheme defied Mackie's agricultural policy that we saw in the previous chapter. Mackie had insisted that no agricultural scheme and project should be carried out without field trials and proper investigations. This scheme best exemplifies agricultural planning in this late colonial period. Big agricultural schemes and projects such as NAP and the East African Groundnut Scheme were introduced in British colonies at that time. While most of the schemes have received plenty of careful studies, NAP has not. ${ }^{284}$

\footnotetext{
${ }^{284}$ NAP has receives mention in articles and books without detailed studies. To date, there is only one detailed published study on the scheme. It is a book by K. D. S. Baldwin published in 1957, not long
} 


\section{The CDC \& Economic Development After 1945}

The period after the Second World War was a difficult time for Britain. The Sterling Crisis of 1947 created severe economic hardship for Britain and her gaze was turned toward empire for economic redemption. The Labour government impressed on "individual administrations the need to intensify the exploitation of imperial resources in an effort to use the colonies to earn dollars by exporting to the United States, and save dollars through substitution of imports from the dollar area to Britain." ${ }^{285}$ Earlier, in 1945, Parliament passed the CD\&W Act to help develop the resources of the colonies for the betterment of the colonial people. In 1948, Parliament passed the Overseas Resources Development Act to develop the economic resources of the colonies. The goal of this Act was to supplement what private enterprises were already doing in the colonies. There were areas where private enterprises were not equipped or able to develop the economic resources immediately, and the Act envisioned the British tax payer helping to fund development in such places.

The Act created two corporations: The OFC and the CDC. The Overseas Food Corporation was responsible for increasing world food production. One of the schemes that has been associated with this corporation and has forever tainted it is the East Africa Groundnut Scheme, Tanganyika. ${ }^{286}$ The colossal failure of this scheme was a big disappointment to those who had hopes in the economic potential of the resources of the

after the scheme failed. The CDC suggested to Baldwin to write the book. A long time has passed since Baldwin's book and I think this project deserves a new look and analysis.

285 Hodge, Triumph of the Expert, 208

286 This scheme created in 1947 was taken over by the Overseas Food Corporation in April of 1948. The project was estimated at $£ 24$ million. The scheme was in trouble by the end of 1948 . The scheme was abandoned in January of 1951. Hodge, Triumph of the Expert, 210-211. 
colonies to power Britain during her economic dark times. Of interest in this chapter is the CDC. The corporation was charged with the duty of "securing the investigation, formulation and carrying out of projects for developing resources of colonial territories with a view to the expansion of production therein of foodstuffs and raw materials, or for other agricultural, industrial or trade development therein., ${ }^{287}$ The CD\&W Act of 1945 allocated $£ 300$ million for the development of the colonies. Of this amount, $£ 110$ million was available for the $\mathrm{CDC}$ to borrow for its work in the development of the economic resources of the colonies. The allocation of $£ 300$ million by the 1945 Act implicitly distinguished between the "commercially remunerative" and the "commercially nonremunerative" aspects of economic development. Whereas the CO disbursed grants to the colonial governments for their commercially non-remunerative work of development, a public corporation (the $\mathrm{CDC}$ ) disbursed the funds for the "commercially remunerative" ventures of the British government. As a public corporation, the CDC was independent of the British Parliament in its daily administration. ${ }^{288}$ The belief was that the CDC would help Britain with its balance of payments crisis that resulted from the sterling crisis. Arthur Creech Jones, the S of S, told Prime Minister Clement Attlee that the CDC was going to increase colonial production "on an economic and self-supporting basis with an eye to the production of foodstuffs, raw materials and manufactures whose supply to the UK ... will assist our balance of payments." ${ }^{289}$ The British government wanted the CDC to work and the $\mathrm{S}$ of $\mathrm{S}$ believed it would. The $\mathrm{S}$ of $\mathrm{S}$ had powers of directions over the

\footnotetext{
287 HMSO, Overseas Resources Development Act, 1948, Section 1.

288 E. R. Wicker, "The Colonial Development Corporation (1948-54)," The Review of Economic Studies 23, 3, (1955-1956): 213-214.

${ }^{289}$ John Kent, British Imperial Strategy and the Origins of the Cold War, 1944-49 (Leicester: Leicester University Press, 1993), 132.
} 
CDC. He could give a general direction to the CDC board on matters that affected the public interest. The CDC also relied on the $\mathrm{S}$ of $\mathrm{S}$ and the Treasury to approve loans for every scheme that was carried out. This is because the CDC itself had no money of its own.

Although the CDC could operate projects solely on its own, its preference was to operate in partnership with commercial enterprises in carrying out development schemes. When such an arrangement was entered into, there had to be a separate company founded in which equity was shared and the CDC might directly control the operations of the company. When the CDC entered into such partnerships, it was expected that it would have controlling interests. ${ }^{290}$ In the early years of the CDC, the time period between 1948 and the end of 1950, it tended to be the sole owner of the projects or schemes that it carried out. This was in stark difference from the idea of a public corporation in Britain in which such bodies solely owned and controlled the scheme. Only eight of the fifty projects that were in existence by the end of 1950 were in partnership with private enterprises. After 1950, the CDC changed its model and was more engaged with private enterprises for its schemes and projects. Wicker writes, "By the end of 1953 the Corporation had reduced the number of projects for which it was solely responsible to sixteen, and in five of these the C.D.C. was negotiating for association with private enterprise or colonial government authorities." 291 The change in policy was as a result of the heavy losses the CDC suffered in its early years. In order for the CDC to show "vigorous and even spectacular activity" in its work of developing the colonies, the CDC

290 HMSO, Colonial Development Corporation, 1948, 5. The booklet was prepared as a guide to the objects and methods of operation of the Corporation.

291 Wicker, "The Colonial Development Corporation, 1948-1954," 216. 
engaged in some schemes that were not economically and commercially sound. ${ }^{292}$ The change in 1951 was as a result of the conservatives coming to power. They decided to disband the $\mathrm{OFC}$ and subjected the $\mathrm{CDC}$ to stringent regulations, making it much more like a development bank.

\section{The Oilseed Mission to Nigeria}

The active presence of the CDC in Nigeria came by way of the oilseed mission that visited West Africa in 1947. After the Second World War, there was great demand for oilseeds in Europe. The oilseed mission to West Africa was mandated "to investigate the possibility of the production of groundnut and other oilseeds in Nigeria."293 This oilseed mission reported that the area in which the NAP would eventually be situated showed possibilities for large scale mechanized production of groundnuts. As envisioned by the oilseeds mission, NAP had three goals:

1. To increase cereal and oilseed production for the local market and for exports.

2. To settle an unpopulated area with new village communities in which there is a combination of collective mechanized farming and local agricultural skills and experience.

3. To formulate a new pattern of farming which could be extended to cover all the cultivatable land in the area and could be applied to other parts of the country. ${ }^{294}$

Nigeria was skeptical of introducing large scale mechanized farming in a peasant economy. Before the introduction of the wooden ploughs in the late 1930s, attempts at introducing small scale mechanized farming had failed mainly due to the cost of ploughs

\footnotetext{
292 H. Nutcombe Hume, "The Work of the Colonial Development Corporation", Journal of the Royal Society of Arts, 104, 4984, (1956): 785.

${ }^{293}$ G. A. Abu, P. I. Ater and D. Abah, "Profit Efficiency among Sesame Farmers in Nasarawa State, Nigeria," Current Research Journal of Social Sciences 4,4 (July 30, 2012): 262.

${ }^{294}$ A CDC Scheme for the Agricultural Development of an area near Mokwa, Nigeria (Niger Agricultural Project, Ltd), 20 May, 1953, TNA: CO 554/458.
} 
and their maintenance. Nigeria was persuaded to participate in this scheme because it would be successful. The Gezira scheme ${ }^{295}$ in the Sudan was used as an example of the success of such schemes that partnered between commercial corporations and tenant cultivators. The colonial state dispatched two officers to go to Gezira on a fact-finding mission in April of 1948. These officers visited both Gezira and the Mechanized Crop Production Scheme at Ghadambaliya. ${ }^{296}$ The report of these two officers was influential to the future direction of the scheme. There was a change "in emphasis from the increase in the production of groundnuts, sought by the Oilseeds Mission, to mechanized farming to give genuine independent settlers more corn to eat and larger share of crops to sell.,"297 The production of food that the farmers could themselves consume was important and this was in line with the policy that Mackie had laid down in the early 1940s. He had insisted that farmers who cultivated cash crops must also be self-supporting by cultivating enough food to feed their own families.

\section{Early Settlements and Cultivation at NAP}

In 1949, the CDC was asked by the CO to join the Nigerian colonial government in establishing this scheme. ${ }^{298}$ In establishing the scheme, the CDC and Nigeria agreed that the CDC would finance the scheme but Nigeria would be responsible for the losses incurred in the first seven years of the scheme up to $£ 31,793$. Also, Nigeria guaranteed the $\mathrm{CDC}$ a $3 \%$ annual return in the first ten years of the scheme. Based upon this

\footnotetext{
295 More on the Gezira scheme later.

296 The two officers were Mr. T. Weatherhead who was a Senior District Officer and Mr. D. W. H. Baker who was the Principal of Schools at the Agriculture Department. K. D. S. Baldwin, The Niger

Agricultural Project: An Experiment in African Development (Oxford: Basil Blackwell, 1957),12-14.

297 Baldwin, The Niger Agricultural Project, 12-13.

298 Ibid., xiii.
} 
agreement, work started at the site of the scheme in June of 1949. When work began on the site, the staff included a manager and eight expatriate staff. No Nigerian staff was employed at the professional level. The few Nigerians who were employed were clerical staff. This initial team of expatriate staff established a training farm and an engineering training school for the local boys. The involvement of Nigerians at this initial stage of the scheme was by way of a local advisory committee. The chairman of this committee was appointed by the Resident of the Niger Province. This committee was made up mainly of Africans. Members were drawn from the traditional authorities and also included the provincial heads of development departments. Though this committee had the title of an advisory committee, their advice did not involve the technical operations of the scheme. Their main responsibility was in choosing the settlers and dealing with their welfare and complaints. $^{299}$

As executed, the scheme had three partners, the principal ones being only the Nigerian colonial government and the NAP. The settlers who were the third partner in the scheme had no administrative representation or decision-making. These partners and their responsibilities were:

1. The Nigerian colonial government. Through the traditional authorities, it provided the land that was needed, the main roads, and the supply of water.

2. The Niger Agricultural Development Project Ltd. ${ }^{300}$ This was the managing company. This company was set up to deal with the problem of who has control

\footnotetext{
${ }^{299}$ Notes on Some Agricultural Development Schemes in Africa, 16 October, 1951, TNA: CO 554/458.

${ }^{300}$ This company was incorporated on 1 March 1950 to manage the scheme. It had an initial capital of $£ 450,000$ subscribed by both the Nigerian colonial government and the CDC equally. Though each share
} 
over the scheme. It was responsible for administering the settlement area; providing the farm roads, fertilizers, tractors and agricultural equipment; providing the technical and mechanical staff; and to clear and prepare the land for the initial sowing of seeds.

3. The settlers. They were responsible for the sowing of seeds, weeding, hoeing, and in some cases harvesting. ${ }^{301}$

The model for the scheme was the crop-sharing undertakings that had already evolved in the Gezira Cotton Scheme in the Anglo-Egyptian Sudan that was considered very successful. However, the designed plan for Mokwa only shared some similarities with Gezira. Like Gezira, the land was parceled out to the different settlers. Gezira settlers each received about ten acres of land. In the Mokwa scheme, the idea was to create ten settlements and each settlement was to have eighty farmers with their families. Each farmer was awarded 48 acres to cultivate, half of which would be fallow. Apart from the acreage awarded to the farmers, there was to be another 576 acres that would be used as a demonstration farm to conduct trials on crops and rotations. The goal was to have about 65,000 acres of usage when the project was in its full maturation. ${ }^{302}$ While the Gezira farmers had ownership of the land, the settlers at Mokwa did not own the land. They were only granted use of the land.

In the case of Gezira, there was a tripartite partnership structure: the cultivators, the government and the Sudan Plantation Company. Though Mokwa had a tripartite

was $£ 1$, the first share which was issued to the CDC carried two votes. This was to ensure that the CDC had control of the company.

${ }^{301}$ The Niger Agricultural Project, 20 May 1953, TNA: CO 554/458.

${ }^{302}$ Ibid. 
partnership structure, the cultivators did not have an ownership stake in the scheme. The farmers were tenants of the company and the Nigerian colonial government had the responsibility of providing the farmers to the company. In both schemes, the management company provided the technical supervision of the scheme.

There were two main areas where Gezira and Mokwa differed in significant proportions. A major difference was in the area of mechanization. Unlike Gezira, the key innovation in Mokwa was mechanization. Mechanization was to showcase the power of modern technology in transforming rural agriculture. At Gezira, the tenants were responsible for their own labor force to weed, pick the cotton, clean the fields and maintain their irrigation ditches. ${ }^{303}$ Another important difference between the two schemes was in the area of research. It took several years of experimentation and field trials through pilot schemes before settlers were brought into the Gezira settlement. This was not the case with the Mokwa scheme. The scheme was quickly put together without field trials and experimentation. This as we shall see later became one of the reasons for the failure of Mokwa.

Despite the lack of field trials and experimentations, the first group of farmers moved into the first settlement in 1951. This settlement was called Ndayako. The second settlement, called Pannini, was established in 1952. The original plan was to have eighty farmers in each settlement. Three years into the project, only 135 farmers had been settled. The Ndayako settlement had 78 farmers instead of the eighty farmers that were planned and the second settlement at Pannini only had 57 settlers. The Pannini settlement

\footnotetext{
303 Peter F. M. McLoughlin, "The Sudan's Gezira Scheme: An Economic Profile," Social and Economic
} Studies 12, 2 (June, 1963): 181. 
was comprised of people from outside of Mokwa. The first settlement had mostly people from within the Mokwa area.

The progress of land clearance was also slow. In March of 1952, only about 7,754 acres of land had been cleared. The average cost of clearance per acre in November of 1951 was $£ 12.8$ and in February of 1952 , it was $£ 12.13 .{ }^{304}$ The continuous high cost was associated with removing the tree stumps from the land that had been cleared earlier. NAP was supposed to be a project that would showcase the power of mechanized agriculture. The land was initially ploughed with Fordson Major diesel tractors and Ransomes Dragoon disc ploughs. The clearing was done in a hurry and no one considered stumping the trees. These concealed roots ended up creating problems for the equipment and slowed the progress of the work. More than 5,000 acres of land that had already been cleared had to be stumped and rooted manually by hand. As a demonstration of how deep the roots were, the manager of the scheme kept in the verandah of his office a lateral root removed that was 54 feet long. ${ }^{305}$ It cost about $£ 13$ per acre to remove the stumps and to root the land. At the end, clearing was no longer done by machines but by hand because it was considered by the management of NAP to be cheaper than any other method. Mechanized clearing was considered to be extremely expensive in equipment, maintenance, and staff. ${ }^{306}$ Mechanized clearing thus had to be abandoned. Mokwa's problems mirrored those of the East Africa Groundnut Scheme started only a little earlier than Mokwa. The Groundnut Scheme like Mokwa was hastily conceived without

\footnotetext{
304 Colonial Development Quarterly Report on Schemes in Operations for quarter ended 16 June, 1952 , TNA: CO 7304/52.

${ }^{305}$ Report of G.W. Nye, O.B.E. Secretary of State's Deputy Agricultural Adviser's visit to Mokwa, 29 December 1952, TNA: CO 554/458.

${ }^{306}$ Notes on Some Agricultural Development Schemes in Africa, 16 October, 1951, TNA: CO 554/458,
} 
allowing sufficient time for field trials and experimentations. This scheme was also billed to be fully a mechanized scheme. Like Mokwa, this scheme experienced problems with the operation of tractors and supplying the spare parts needed. The planners did not take into consideration "the high attrition rate of the second-hand tractors, or the challenges involved in removing the long, sinewy roots of the Kongwa scrub, which clogged the illsuited rooters, causing extended delays. ${ }^{, 307}$

Beyond the problem of mechanized clearing were doubts that the management of NAP began to have about the capabilities of the African farmer. Having been observing the settlers for about a year, the management was not certain that the African farmer was capable of cultivating the 48 acres of land that had been allocated to him. There was no certainty that even after the company had ploughed the land and prepared it for sowing, the farmer was capable of looking after the 24 acres of land under cultivation. According to the regulations, half of the land had to remain fallow. This doubt raised a serious problem for the economics of the scheme. O. E. Mercer, the regional manager of the CDC in West Africa, believed that the economic viability of the project depended on how much of the land the individual settler could cultivate. Given that the project company had already spent half of its capital on a project that had not reached $25 \%$ completion, the question was whether the scheme should continue expanding with the rest of the settlements or whether it should downsize. If the company chose to continue with the full implementation of the scheme, then more capital would be needed. ${ }^{308}$ The decision was made that the company should await the end of the year report in order to determine the

\footnotetext{
307 Hodge, Triumph of the Expert, 211.

${ }^{308}$ Notes of a meeting at the CDC, 29 June, 1952, TNA: CO 554/458.
} 
way forward. However, the company at this time was short of working capital and a suggestion was made that the CDC should advance a loan to the company if the Nigerian colonial government was unable to make arrangements for further capital in $1952 .{ }^{309}$ The June 1952 report of the Mokwa scheme, while not as bad as the report ending in March, still showed a bleak future. The general outlook in terms of production looked bad. The cost of production greatly exceeded the value of output. The total acreage cleared by this time was still only 8,225 acres. There was a delay in overhauling the tractors because of the delays in the delivery of the spare parts. Spare parts were not found locally and so they had to be imported. The cost of using the tractors was much higher than had been expected because of the cost of maintenance. In fact, the tractor running cost was $100 \%$ over the estimates. ${ }^{310}$

The increased cost of removing roots meant that the company was already spending much more capital than was budgeted. By the second quarter of 1952, it became obvious that the work could not continue without some additional capital infusion. To alleviate the issue of capital, the CDC and the Nigerian colonial government equally subscribed to an additional share capital of $£ 60,000$ to further finance the scheme. For the quarter that ended in September of 1952, however, the scheme continued to fall outside of its estimates. For example, it cost $£ 11,258$ to run the tractors. This was more than $100 \%$ beyond the estimates. The estimates for seeds and fertilizers were $£ 5,000$, but the company ended up spending only $£ 1,500$. The reason less money was spent than estimated was because they could not find enough settlers to plant the seeds and to use

${ }^{309}$ Colonial Development Quarterly Report on Schemes in Operations for quarter ended 16 June, 1952, TNA: CO 7304/52.

${ }^{310}$ Ibid. 
the fertilizers. For the first nine months of the year, the company had already lost $£ 22,763$ and estimates were that the losses might be about $£ 30,000$ by the end of the year. The outlook for 1953 looked bleak, as a preliminary study showed that the scheme would continue to operate at a loss. ${ }^{311}$

At the end of 1952 , the company had lost $£ 29,599$, an amount that was very close to the projected loss of $£ 30,000$ in the September report. This was a loss of about $£ 250$ per settler. The total amount of land that was cleared by the end of the year was only 8,684 acres. Just 1,704 acres of land was cleared for the whole of 1952. It became obvious that in order for the scheme to become profitable, the revenue per acre had to increase dramatically and the possibility of that was not in sight. The crops also had underperformed. Due to dry weather at the time of planting, the groundnuts failed. The bambarra nuts performed a little better, but maize and millets failed. The only crop that performed well was guinea corn. ${ }^{312}$ The failure of groundnuts would not have been a surprise to the settlers. They had earlier shown reluctance in planting them because they understood that they would result in poor yields given the time of the year that they were being planted. Groundnuts were usually planted in May, but farmers were asked to plant groundnuts in July. They could not be planted earlier because they had not finished preparing the land for cultivation. The experts that ran the scheme believed that the seeds would still perform well under the circumstances. The results proved the settlers right. The poor yield was bad for the settlers who had to rely on one third of the yield for their own subsistence. Many of the settlers were unsatisfied and wanted to leave the

\footnotetext{
${ }^{311}$ Ibid.

${ }^{312}$ CDC Annual Report for 1952, TNA: CO 554/458.
} 
settlement. By the end of the year, discussions were already opened between the CDC and the Nigerian colonial government as to the future of the scheme. ${ }^{313}$

\section{NAP as an Experiment}

K. D. S. Baldwin argued in his book, The Niger Agricultural Project: An Experiment in African Development that the scheme was never expected by the CDC to be very profitable. He writes, "The scheme was never expected by the Corporation to be very profitable. The Corporation pointed out to the Government that a wide-scale social experiment of this sort brought great development advantages to the country concerned, but was an abnormal risk with small return for any party unless the Government took a large share in the undertaking." ${ }^{\text {314 }}$ The scheme was a good example of what James Scott calls "High modernist." At the heart of high modernism, he argues, "was a supreme selfconfidence about continued linear progress, the development of scientific and technological knowledge, the expansion of production, the rational design of social order, the growing satisfaction of human needs, and, not least, an increasing control over nature (including human nature) commensurate with scientific understanding of natural laws. ${ }^{\text {} 315}$ Thus, Mokwa was considered a social experiment that would bring about progress and change the human conditions of the people.

Christophe Bonneuil observes that the language of experimentation was one that was deliberately used in development narratives beginning from the 1930s. Late colonial

\footnotetext{
${ }^{313}$ Ibid.

314 Baldwin, The Niger Agricultural Project, 21.

315 James Scott, Seeing Like A State: How Certain Schemes to Improve the Human Condition have Failed (New Haven: Yale University Press, 1998), 89.
} 
development schemes were viewed as experiments that were both scientific and social. He argues that these schemes had two things in common: they put experts in power and the physical and social space of the schemes was designed according to plans produced by scientists. ${ }^{316}$ Before this time period, political officials relegated technical staff and the scientists who worked in the African colonies to second-class status. Nigeria was no exception. In the last chapter, I showed how the provincial and district officers treated the agriculture department staff. Mackie resigned his service in Nigeria as a result of the poor treatment of technical staff. In this late colonial period when massive agricultural schemes were favored, the scientists and the technical staff were very powerful. They designed these schemes, which were supposed to showcase the power of science in the development of rural and backward regions. African colonies saw an upsurge of new scientists and technical officers who pontificated over development in Africa. These had the kind of authority and prestige that those who had worked before them in Africa could have only dreamt of. Bonneuil writes that these experts "were mobilized by the colonial state to help appropriate and master African environments, pathologies, and societies. In British Africa, the 1930s saw increasing concern with soil erosion and deforestation as well as with malnutrition and public health. These brought to power a flood of experts. The gospel of soil conservation legitimized scientific measures (including confinement of people in settlement schemes, where access to land and grazing were restrained) against 'irresponsible' Africans who had to be prevented from destroying their environment." ${ }^{\text {,317 }}$ The value placed on experts thus changed during this late colonial period. In the early

\footnotetext{
316 Bonneuil, “Development as Experiment,” 265-267.

317 Ibid., 265.
} 
years of colonial rule "the administrative officers were more powerful, more conspicuous and relatively more numerous. ${ }^{\not 318}$ However, in the late colonial period, the technical officers "considerably outnumbered the Administration in the field and progressively exerted more influence at all levels of government." ${ }^{\prime 319}$ Mokwa witnessed the presence of many foreign experts who were unaware of the local conditions unlike the previous agricultural department staff who had spent several years working in the area and understanding culture. As Baldwin rightly observes, "Undue haste at Mokwa gave the farmers no time to satisfy themselves that the new methods were better than their own. Furthermore, none of the senior staff had worked in Nigeria before. None spoke Nupe or even Hausa, hence all their dealings with the farmers had to be through interpreters. Finally there was a serious break in the continuity of staff at the end of 1950. It is difficult to see how this could have been avoided. If no senior staff were available in Nigeria, they had to be recruited from somewhere else." ${ }^{" 320}$ After the resignation of Mackie, many other senior staff had either resigned or requested to leave Nigeria. Also, the staff who disagreed with the direction of Mokwa and how the whole project was rushed, also left the Nigerian service.

The second common feature of this period was that the physical and social space of the various schemes were in accordance with plans produced by "the scientific bureaucracy." Members of this bureaucracy included "engineers, planners, technocrats, high-level administrators, architects, scientists, and visionaries." ${ }^{321}$ They believed that the

\footnotetext{
318 Robert Chambers, Settlement Schemes in Tropical Africa (Abingdon: Routledge, 1969), 17.

319 Ibid.

320 Baldwin, The Niger Agricultural Project, 194.

${ }^{321}$ Scott, Seeing Like A State, 88.
} 
human condition could be improved through social engineering. Thus, "Agricultural and social activities were construed in terms of uniform fields and villages, with rigid schedules. Farmers were told what to plant and what cropping system to use. The timing of each farming operation was centrally controlled." ${ }^{322}$ Here was a social experiment in which a traditional society was completely reorganized. The idea was that by organizing a society in this way, production was going to increase. This social experiment was created because of the circumstances that the Europeans found in Africa. The places where these settlement schemes were going to be located had sparse populations and it was difficult to bring the people under their control and to make them do what they wanted. Locating the settlements in sparsely populated places provided at least two advantages: they had the land that they needed without undue pressure from the locals and they could exercise more power. By creating these new settlement schemes, the Europeans were attempting to shift the balance of power from the agrarian community to the company. ${ }^{323}$ Settlement schemes "were the laboratories where the developmentalist state attempted to shape agrarian societies and environments so as to render them compliant to 'development': more productive, more commensurable to expert knowledge, and more amenable to state intervention." 324 This explains why the Nigerian colonial government was willing to invest in NAP even though it knew that it may not be profitable. It could invest in the scheme because it saw value in the social experiment. The Gezira Scheme in the Sudan is a good example of how the Europeans changed a whole social order. The area where the scheme was established was treated as if nothing

322 Bonneuil, "Development as Experiment," 267.

${ }^{323}$ Ibid., 268.

${ }^{324}$ Ibid., 269. 
had existed there before. The British did not take into consideration the social organizations that existed and the patterns in which land was used. The goal was to bring the people under British control and create a new social order. This scheme as Victoria Bernal notes, "represented an attempt not simply to remake or reform rural Sudanese society, but to create a (colonial) Sudanese society: a homogenous society of hardworking and disciplined peasants. The British did not try to transform local practices so much as obliterate them, starting literally from the ground up, with new systems of production and productive relations of their own design. ${ }^{, 325}$ The area in Mokwa was treated as such and if NAP was successful, this would have been replicated in other parts of Nigeria. Unlike Mokwa, Gezira was to a large measure successful. There are two important reasons for this: the farmers in Gezira clamored to be part of the scheme while those in Mokwa were not interested in being part of the scheme. There was no pressure on land in Mokwa unlike Gezira where there was demand for the land. The second important reason is that Gezira was preceded by decades of experimentation on a small scale and Mokwa did not undergo experimentations.

Beyond the fact that NAP was a social experiment, to the scientists and technical experts who created the scheme, it was a showcase of the power of planned mechanized agriculture. The poor results and the near bankruptcy of the scheme just two years after the settlements had been established created doubts as to its successful future. It is important to note that when the oilseeds mission conceived this scheme, it was not intended to be a social experiment. It was expected that it would be a profitable venture

\footnotetext{
325 Victoria Bernal, "Colonial Moral Economy and the Discipline of Development: The Gezira Scheme and 'Modern' Sudan," Cultural Anthropology 12, 4, (1997): 453.
} 
that would help alleviate postwar shortages fast. When the CDC examined the proposed scheme, they ruled it a social experiment and marketed it to the Nigerian colonial government as such. As the scheme began, neither the settlers nor the staff saw themselves as part of a social experiment. Between the settlements of the first farmers up until 1952, the scheme was not being described as an experiment. I believe that those who were actually part of the work in the scheme believed that the scheme was going to be successful economically. A major shift occurred in 1953 when the scheme was more and more often described as an experiment. As was the case in the East Africa Groundnut Scheme, the rhetoric of experimentation "helped to justify the huge amounts of money lost in such schemes and to excuse in advance all errors." ${ }^{, 326}$ In 1953, it was obvious the scheme was failing. But describing it as an experiment allowed the scheme to avoid the public embarrassment that its failure would cause both the CDC and the Nigerian colonial government who were the two major investors in the scheme.

The major shift in the rhetoric of experimentation occurred when Elspeth Huxley, a British/Kenyan writer and journalist, contacted the $\mathrm{CO}$ to request information on the progress in Mokwa. She had earlier visited Nigeria and experienced first hand the high hopes that the people had about the scheme. In February of 1953, she was writing a piece that touched on NAP and wanted certain facts about the scheme's progress. In her letter to the $\mathrm{CO}$, she wrote: "One has to be a bit careful with these things - one may write that it is the blue-eyed pet of the Government and full of bright promise, and then find that it has fallen under a cloud and is about to be closed as uneconomic."327 The CO sent a

\footnotetext{
326 Bonneuil, "Development as Experiment," 268.

${ }^{327}$ Huxley to Evans, 25 February, 1953, TNA: CO 554/458.
} 
proposed reply they had prepared for her to the CDC, which was directly involved with the scheme. In it they wrote that, "I think that it would be preferable not to treat the scheme as a 'blue-eyed pet of Government' but as a serious and rather expensive experiment which would ultimately break even financially and point to a possible way of mechanising African, peasant agricultural production. ${ }^{328} \mathrm{C} . \mathrm{W}$. Dumpleton of the CDC responded to $\mathrm{M}$. A. Willis of the $\mathrm{CO}$ requesting a modification in the document of any suggestion that the scheme can be made to pay. ${ }^{329}$ The CDC knew that there was no way the scheme would become economically viable. They were more comfortable with the language remaining as that of experimentation. At the end, the response that was sent to Elspeth Huxley read, "I think that it would not be preferable to treat the scheme as a 'blue-eyed pet of Government' but as a serious and rather expensive experiment. It might also be desirable to point out that it will probably be necessary to wait for some years before the value of the scheme can be assessed." 330 This response was carefully worded and did not include the profit motive of the scheme. The scheme was an expensive experiment, they argued, but it was going to take some years to assess its actual value. What was the actual value of the scheme? The $\mathrm{CO}$ would later argue that it was not economic. By saying the scheme was just an experiment, the emphasis was no longer on profitability but on knowledge gained. Huxley's response to the information received showed that she was not convinced of the argument the $\mathrm{CO}$ was now making. She was critical of their response. In a diplomatic way, she wrote: "All that you say is interesting and confirms the general experience that none of these big mechanized schemes is really

\footnotetext{
${ }^{328}$ Willis to Dumpleton, 11 March, 1953, TNA: CO 554/458.

${ }^{329}$ Dumpleton to Willis, 13 March, 1953, TNA: CO 554/458.

${ }^{330}$ Evans to Huxley, 16 March, 1953, TNA: CO 554/458.
} 
economic and the same goes for land settlement. I quite agree they have a value as experiments even if they only prove negatives. Unfortunately (perhaps) a great many Africans now feel that mechanization will solve all problems and get round the food shortage everyone warns them about." ${ }^{331}$ Huxley's own experience spending three months traveling in Kenya and seeing the agricultural schemes that were carried out there left her convinced that there was value in these agricultural schemes. Her book, $A$ New Earth, tells of many success stories despite the problems of agricultural development in Africa. She devotes a chapter of her book to discussing the Meru settlement schemes, which she claims everyone was proud of "because of their success and above all of their economy."332

\section{Determining the Future of NAP}

With the shift in the rhetoric to that of experimentation, the important question that arose was the future of NAP. It was as if this was a preparation for the announcement of the failure of the scheme. Most of 1953 was occupied with debates on the future of the NAP. While J. D. Brown, the director of agriculture in the Northern Region, where the scheme was located, believed that it was a failure and it should be ended, the local Resident of the Niger Province, M. V. Rackhouse, made a strong case for continuing the scheme. Brown's argument was that the scheme was uneconomic and the knowledge that would be gained from the scheme was not worth spending $£ 50,000$ each year. At the end of 1952, the approximate cost of producing an acre of groundnuts or guinea corn was £7.9. Even at a target of six settlements, the calculations showed that the cost of

${ }^{331}$ Huxley to Evans, 17 March, 1953, TNA: CO 554/458.

332 Elspeth Huxley, A New Earth: An Experiment in Colonialism (London: Chatto \& Windus, 1960), 217. 
producing an acre would not fall below £6.2. The company’s revenue was dependent on the value and field of the crop as well as the output of the settlers. The annual yield of groundnuts was taken at $560 \mathrm{lbs}$ per acre and guinea corn at $1120 \mathrm{lbs}$ per acre. The price of groundnuts in 1953 was $£ 36$ a ton and that of guinea corn varied. A reasonable and fair market price of guinea corn for the sake of estimates was $£ 15$ a ton. The company based future prospects on a price of $£ 28$ for a ton of groundnuts and $£ 12$ for a ton of guinea corn. If the annual yield of groundnuts was $560 \mathrm{lbs}$ per acre, then the company's revenue would be two-thirds of that. At $£ 28$ a ton, that would be about $£ 4.13$. The annual yield of guinea corn was $1120 \mathrm{lbs}$ per acre of which the company was entitled to two-thirds. At $£ 12$ a ton, that would be about $£ 3$. Brown's argument was that if six settlements were operating at a full capacity, the cost of cultivating an acre would still be $£ 6.2$ per acre while the revenue per acre for groundnuts would be $£ 4.13$ and that of guinea corn $£ 3$. Based on the above calculations, the company would still lose $£ 2.07$ per acre in the cultivation of groundnuts and $£ 3.2$ per acre in the cultivation of guinea corn. He argued that there was nothing to suggest that "this revenue can be bridged by increased efficiency in the use of machines, and on the basis of six settlements the price of groundnuts would need to rise to $£ 40$ a ton before ends could be met. Even on a basis of ten settlements maturing in twelve years the estimated cost of cultivation shows little or no margin of profit from this revenue."

Brown also believed that the existing structure of remunerating the settlers did not encourage them to cultivate more. Settlers were required to cultivate 24 acres while they

\footnotetext{
${ }^{333}$ Brown to Permanent Secretary of the Ministry of Agriculture and Natural Resources, Lagos, 26 March 1953, TNA: CO 554/458.
} 
allowed 24 acres to fallow. Brown did not believe that this was beyond the capabilities of the settlers. He noted that there were indications that under the instituted structure even the better settlers were unwilling to cultivate the full acreage. The reason he felt was because they were required to do too much for too little pay. He wrote: "It is possible that they may ask themselves whether they would not be happier cultivating even less than 8 acres in the bush in complete freedom rather than enjoying the products of 8 acres cultivated under the direction and management of the N.A.P." 334 The problem here was not the backwardness or conservatism of African farmers, it was the project design. The amount of work the Africans were required to do was too onerous and the return was too little.

One of the reasons advanced in the reports for the poor yield of crops in 1952 was weather. The argument from the management of the scheme was that the low yield resulted from the complete drought in August. Brown rightly argued that "Mokwa is in a rain belt which more often than not has a 'small dry' period in July and August (unlike the northern groundnut areas) and this factor is one of the many peculiarities of the belt and only one of the problems that have to be met at Mokwa."335 That the technical experts were not aware of this shows how much they ignored the local wisdom. Nigerian agriculture, as argued in the previous chapter, since Faulkner and through Mackie's time had a history of experimental trials and research. That NAP did not go through such trials was a result of the urgency in getting the scheme started to cater to the shortage of the oilseeds. Most people born in this region of Nigeria know of the "August Break," a

\footnotetext{
${ }^{334}$ Ibid.

${ }^{335}$ Ibid.
} 
period marked by lack of rainfall. Brown's conclusion was that there were no prospects that this scheme would ever return any financial profits for its shareholders, that the scheme was ahead of its time, and the mechanization of agriculture in the Northern region "will not be economically feasible until prices of export crops on the one hand and local wage rates on the other, rise very much higher than they are at present." ${ }^{336}$

On the other hand, the Resident of the Niger Province, Rackhouse, had positive prospects as to the future of the scheme. He argued that the scheme should not be abandoned because it served a purpose beyond the immediate economic benefits. He said the success of the scheme could not be measured based on the total yields or finance "but only through visual contact with the scheme by those who have seen the improved tilth after ploughing and the solid expanses of miles of growing corn in 1952 and of growing groundnut in 1951." ${ }^{337}$ The idea of visual contact was to show what was new and modern. This was to distinguish what was now done at NAP with the traditional system of cultivation. The idea of visualization was important and in the 1960s IR-8 was widely used in Southeast Asia to distinguish tradition and modernity and also as "symbolic divider marking the onset of a new political and economic dispensation." ${ }^{, 338}$ The impact of this scheme for Rackhouse was more than the economic bottom line. Rackhouse saw the scheme as a complex scheme that would take time to sort out. Beyond it being an agricultural scheme, it cut across different sectors of the Nigerian society. For that reason, the scheme was not only plagued by technical problems but also by "economic,

\footnotetext{
336 Ibid.

${ }^{337}$ Memorandum by Rackhouse on the Niger Agricultural Project, 2 April, 1953, TNA: CO 554/458.

338 Nick Cullather, "Miracles of Modernization: The Green Revolution and the Apotheosis of

Technology," Diplomatic History 28, 2 (April 2004): 229.
} 
administrative, political and sociological problems which must also be solved. Even on a small scheme, a solution to such a variety of problems can not be obtained over a short term." 339 Rackhouse believed that the duration for which the scheme was in operation was too short to condemn it to failure. Schemes of this nature took time to mature and so the schemes should start small and build up slowly. He argued that the administration of NAP was based on the Gezira Cotton Scheme in the Sudan. It took the Gezira scheme 50 years to reach its fruition of a million acres. He noted that at the initial stages of the Gezira project, "moderate targets were often being reduced in scope."340 The Gezira scheme started with a pilot project of only about 1.038 acres irrigated by pumps in 1910 . It was only after the successful production of cotton that work started on the construction of a dam in Sennar in 1913. World War I interrupted the construction of the dam and it was finished in 1925. Between those years of constructions, additional pumps were installed to help with irrigation. ${ }^{341}$ In terms of planning and execution, the Gezira scheme had a long view in mind. Though it has often been hailed as one of the major successes of agricultural development planning in Africa, Tony Barnett argues that in broader historical terms it is not. It is "stagnant, holds little hope of continually rising living standards for its inhabitants, and, as a major component of the Sudanese economy, it exposes that economy, and thus the society, to considerable potential and actual instability." ${ }^{342}$ Rackhouse wanted NAP to be looked upon as Gezira and given several years for it to mature. His reasoning was that NAP had the potentials to help in the

\footnotetext{
${ }^{339}$ Memorandum by Rackhouse on the Niger Agricultural Project, 2 April, 1953, TNA: CO 554/458.

${ }^{340}$ Ibid.

341 The Gezira Scheme Past and Present. A pamphlet issued by the Information and Publication Section of the Sudanese Government, 1977, 7.

342 Tony Barnett, The Gezira Scheme: An Illusion of Development (London: Frank Cass, 1977), 15.
} 
development of peasant farming across Nigeria. The question then becomes, how long did the scheme need to be in operation before it could be determined if it was successful? Should it be 50 years like the Gezira project or seven years as it was originally planned? These were questions that Rackhouse did not answer.

Rackhouse was not absolutely sure that NAP would be successful. His argument was that if NAP failed, it would help prevent repetition elsewhere. For him, it was an experiment and thus he argued strongly for its continuance. He wrote:

The experiment is only beginning. On the agricultural side, this season is the first when the ploughs have had comparatively rootless land to operate in.... A curtailment of the scheme now would be a great disappointment and set-back to the Native Authorities and the people of this Province and to all those from outside who have followed its progress with the greatest interest. ... This experiment is being closely watched at home and in other colonies and should not be abandoned before failure is clearly demonstrated. ${ }^{343}$

Rackhouse's defense of the scheme was a question of prestige. Even at this late stage, he was arguing that the scheme should be expanded to six settlements and then later to the ten settlements that were originally planned and that the government should be responsible for the capital to achieve this. He also saw the merit of the scheme as it served as a model for other areas. He wrote, “... this scheme must be regarded as an experiment which is to some considerable extent aimed at solving land development problems which also occur in other African colonies." 344 The Inspector-General of agriculture in Lagos agreed with Rackhouse that the scheme should be considered as an experiment. He wrote, “The Resident, Niger Province, quite rightly states that the project is an experiment, and is only just beginning. There should be no consideration of

\footnotetext{
${ }^{343}$ Memorandum by Rackhouse on the Niger Agricultural Project, 2 April, 1953, TNA: CO 554/458. ${ }^{344}$ Ibid.
} 
abandonment as too much is at stake, not solely from the consideration of invested capital, or from the requirements of the local area, but from an all-Nigerian development aspect. ${ }^{, 345}$ The issue here was that of prestige. Abandoning this scheme would lead to doubts about colonialism and its ability to deliver the goods.

In arguing that the scheme was an experiment, this means that lessons were going to be learned from the scheme whether good or bad. If we agree that this project was purely an experimental scheme as has been argued by the major stakeholders, then it was a very expensive experiment. It was expensive not only in terms of the financial resources poured into it but it was also in terms of the human resources. Apart from the Europeans who managed the scheme, many African farmers and their families had invested their time and labor into what was not sold to them as an experiment. The farmers who were recruited for the farms were not told they were living laboratories. They had hopes of better agricultural production in the scheme. The community at large was affected as the scheme tried to create an artificial community in which the people were no longer directly responsible to their chiefs but to the company. A new social organization and relations never before present were now created. In a way, NAP disrupted completely not only the economic lives of the people but also their social relations. Continuing the scheme in the same pattern for the unforeseeable future meant continuing to destroy both the economic and social lives of the African farmers.

\footnotetext{
${ }^{345}$ Memorandum to the Permanent Secretary of the Ministry of Natural Resources, 9 May, 1953, TNA: CO 554/458.
} 


\section{Negotiating the End of NAP}

In the last section, I discussed the arguments for ending NAP by Brown and the arguments for continuing NAP by Rackhouse. The CDC was determined to withdraw from the scheme because it believed that it had a fiduciary responsibility to British tax payers and should not continue to lose money for what it considered an experiment. By the early part of 1953, the financial stakeholders of NAP felt that they had three possible options on what to do with it: abandon the project, continue it at its present level, or expand it to five or six settlements and then perhaps later to ten. Each of these courses posed a problem. If the project was discontinued, it meant that the stakeholders had to acknowledge that the project had failed. Here, the stakeholders had varying interests. If the CDC was the only shareholder of the company, this would be the course of action it would take because as a corporation, it had a responsibility to it shareholders and profit was part of that responsibility. In assessing whether to wind down the scheme, the Nigerian colonial government had different considerations from those of the CDC. It had to take into consideration "sociological and political factors, and economic considerations besides the single one of profit." 346 To continue the scheme at the present level meant that the project would be continued on an experimental basis, a situation that the CDC might not be interested in funding. If the $\mathrm{CDC}$ withdrew its financial support, the colonial government would be forced to assume full financial responsibility and administrative control of the scheme. That meant that the company founded to run the scheme would now be solely owned by the Nigerian colonial government. There was no doubt that the

\footnotetext{
${ }^{346}$ Memorandum by the Ministry of Mineral Resources, Lagos, 20 May, 1953, TNA: CO 554/458.
} 
CDC wanted Nigeria to take over the CDC's investment at face value. This meant that the Nigerian taxpayer would have to assume the losses of the corporation given that as part of the agreement for the CDC to be involved, Nigeria was going to cover the losses of the first seven years. Expanding the scheme to five or six settlements meant that more capital had to be injected into the scheme. The question was where would this capital come from? The CDC estimated that the total capital required for expansion to five schemes was $£ 560,000$ and to six schemes was $£ 580,000$. The conditions under which the CDC was willing to provide more capital were unfavorable to the Nigerian government. It said it could only do so by debenture, which is basically a certificate of indebtedness. ${ }^{347}$ Given the three actions that could be taken, it seemed obvious that the CDC would withdraw from the scheme. How would they do this?

A discussion had already been opened between the Nigerian Central Government (NCG) and the Northern Regional Government (NRG) on the future of the scheme. While the CDC was awaiting the response from the NCG, it took the step to officially withdraw its support for the scheme. In a letter on the $30^{\text {th }}$ of November, 1953 to M. A. Willis of the CO, the director of the CDC, C. W. Dumpleton, wrote, "We still await the Central Government's definite proposals but I am now writing you formally to seek approval for the Corporation's intention to abandon participation in this scheme and to ask that it shall qualify for waiver of interest." ${ }^{, 348}$ The CO did not provide an immediate waiver sought by the CDC. It did not want the $\mathrm{CDC}$ to just abandon the project but

\footnotetext{
${ }^{347}$ Ibid.

${ }^{348}$ Dumpleton to Willis, 30 November, 1953, TNA: CO 554/458.
} 
wanted the $\mathrm{CDC}$ to negotiate an exit from the scheme with the appropriate local authority. In his response, Willis wrote:

Definite approval, however, would have to await such a satisfactory agreement and the Secretary of State will wish to be given the opportunity to consider the terms of the agreement before it is finally accepted by the Corporation. He will wish in this connection to be given a full report on the reasons which have induced the Corporation to abandon its participation and to be satisfied that adequate arrangements are made under the agreement for an appropriate valuation of any assets belonging to the Corporation which are transferred to other authorities. $^{349}$

Even before the Corporation had the opportunity to respond to the request of Willis, the S of S, Oliver Lyttleton wrote to the Officer administering the Nigerian government. He seemed not to have been aware of the debates that had been going on both at the CDC and also by some of the experts in Nigeria. His letter made reference to the positive report that had been given by G. W. Nye, his deputy agricultural adviser, after his visit to Mokwa in November of 1952. The tone of his letter was very positive and even hoped that other regions of Nigeria may be interested in the project. He offered to send one of his advisers to Nigeria to help with determining a future for the project should there be a need for such assistance. ${ }^{350}$ The information the $\mathrm{S}$ of $\mathrm{S}$ had about the NAP was old; the project continued to experience losses in 1953. He was basing his comments on the assessment Nye had given in his 1952 report in which he concluded that if the project were allowed to proceed without being pressured to be profitable, it would be successful under the present management. ${ }^{351}$

\footnotetext{
${ }^{349}$ Willis to Dumpleton, 23 December, 1953, TNA: CO 554/458.

${ }^{350} \mathrm{~S}$ of $\mathrm{S}$ to the Officer Administering the Government of Nigeria, telegram, 14 January, 1954, TNA: CO $554 / 458$.

${ }^{351}$ Report by G.W. Nye on Niger Agricultural Project, 29 November, 1952, TNA: CO 554/458.
} 
This however, was not the belief of most of the stakeholders in the scheme. It was almost impossible to find anyone who was a major stakeholder in the scheme who in 1954 still believed that the scheme would be successful within three to five years. As I have demonstrated earlier in this chapter, even ardent supporters of the scheme such as Rackhouse were at this time looking at it more as an experiment that would take several years for it to be successful in terms of knowledge gathered. Economic success at NAP was not even a serious factor under consideration. This goes to show the disconnect that existed between the $\mathrm{CO}$, the $\mathrm{CDC}$, the $\mathrm{NCG}$, and the technical experts. When these colonial development schemes are seen from a distance, one may be tempted to see a heavily coordinated attempt by the different elements of the British bureaucracy to carry them out and to exploit the colonies. When these schemes are looked at closely, as in the case of NAP, a disjointed organization with different competing interests is evident. This bureaucratic confusion was sometimes responsible for the failure of these post-war development schemes.

Be that as it may, the Governor of Nigeria, Sir John Macpherson, responded to the 14 January, 1954 letter from the S of S. The governor updated him on the different proposals that were being considered as a result of the CDC's decision to withdraw from the project. The Nigerian Council of Ministers considered four alternative solutions. The first NCG to take over the interest of the CDC in the scheme and then invite the NRG to take over control of the project. The third proposal was for the NCG to take over the interest of the CDC at valuation and then invite the NRG to provide the funds that were needed to cover the recurrent expenditure of the scheme for another five years. The final 
consideration was for the NRG to take over the interest of the CDC and assume all the cost required to continue the scheme for the next five years. ${ }^{352}$ The decision of the Council of Ministers was that the NCG could not assume any future financial responsibility for the scheme, and thus it had no interest in operating the scheme or taking over the interest of the CDC in the scheme. The NCG was willing to transfer its shares in the scheme free of charge to the NRG. The decision was placed by the NCG on the NRG that had the choice either to operate the scheme with or without the CDC or to wind it down. ${ }^{353}$ The NCG's offer to transfer its shares in the scheme to the NRG was not a gift but a liability. It was obvious to the NCG that the scheme was a failure and continuous participation meant investing in a project that would not reap any benefits. This goes to show also that the Council of Ministers was not persuaded by the arguments of both the Niger Resident and the Inspector General of Agriculture. Their papers arguing for the continuance of the scheme were made available to the Council of Ministers. By April of 1954, when a parliamentary question was asked on the future of the scheme, the CO responded clearly that both the Nigerian colonial government and the CDC had withdrawn from the scheme and it was now under consideration by the NRG. The NCG continued to fund the scheme awaiting the decision of the NRG. The reason they did this was to make sure that there was no break in continuity should the NRG choose to continue the scheme. ${ }^{354}$

As the governor reported in May, the NRG was interested in continuing the scheme. It made a bid of $£ 60,000$ for all the assets of NAP. The NCG and the CDC accepted the

352 Macpherson to Lyttleton, 10 February 1954, TNA: CO 554/1269.

353 Ibid.

354 Macpherson to Lyttleton, 3 April, 1954, TNA: CO 554/1269. 
bid. This proposal, however, was subject to the approval of the Executive Council of the NRG. ${ }^{355}$ By taking over this scheme, the NRG was assuming responsibility over the management of the scheme and its employees, who were to become staff of the NRG. The Executive Council of the NRG did not immediately approve the transfer of the company to the Northern Region.

While the NRG saw great value in the continuation of the scheme as an experiment, it had problems with the cost that this would entail. Their plan was to modify the settlement scheme and reduce it to a compact area of about 4,000 acres. A pre-requisite for the scheme was "some further clearing against tsetse fly, re-alignment of holdings and protection against erosion." ${ }^{356}$ The modified scheme was going to closely study mechanical cultivation and cropping and the size of holdings. They were also going to examine the possibility of introducing cattle to the scheme. The scheme needed to solve many technical issues and they felt that an experimental farm would be essential to its success. ${ }^{357}$ With the modification of the scheme, the cost also reduced. The capital cost was going to be $£ 91,500$ and the annual recurrent cost was estimated at $£ 21,000$. They were going to approach the $\mathrm{S}$ of $\mathrm{S}$ to provide $£ 51,000$ grants from the $\mathrm{CD} \& \mathrm{~W}$ funds. This was over and above what was already allocated to the NRG. The NRG proposed to provide the remaining $£ 40,000$. They had a second plan should the S of S refused to grant them the request. They were going to find savings under the agricultural section of their present development plan. For the annual expenditures of the scheme, the NRG was

355 Macpherson to Lyttleton, 13 May, 1954, TNA: CO 554/1269.

356 Niger Agric Project, Mokwa - Taking Over, Memorandum by the Minister of Natural Resources, 27 May 1954, Nigerian National Archives, Kaduna (Hereafter NNAK): 151D.

357 Ibid. 
confident that it could provide $£ 10,000$ annually and was requesting that the $\mathrm{S}$ of $\mathrm{S}$ to provide the remaining $£ 11,000$ as an extra grant. The annual revenue accruing from the scheme in the first year was estimated at $£ 4,000$ and it was expected to cover the cost of ploughing. ${ }^{358}$

In the negotiations with the NRG, both the NCG and the CDC agreed that the $1^{\text {st }}$ of June 1954 should be the date that the full responsibility of the scheme was going to be transferred to the NRG. The long awaited response from the NRG was only received on the eve of the day the official transfer of ownership was supposed to take place. The response was not an approval of the Northern Executive Council, but rather, a request for money from the CD\&W fund to help her cover the $£ 106,500$ that the scheme would cost over the next five years. The basis for such a request was that the cost of running this scheme was an unexpected commitment and it was important that the scheme should be continued. They cited from the S of S own confidential letter to the governor in which he agreed with his agricultural adviser's view that the scheme was important and its value was not only good for Northern Nigeria but would make a valuable contribution to the agricultural development of Nigeria. ${ }^{359}$ Their argument here was that the imperial government had some responsibility to help aid the project with the $\mathrm{CD} \& \mathrm{~W}$ funds. Was the letter sent at this last minute when the NCG and the CDC were about to abdicate responsibility over the project an attempt to force the hand of the $\mathrm{CO}$ to provide funding for the scheme? It may as well have been perceived that way. The NRG itself was afraid that it may be viewed that way. Thus, the letter said toward the end: "I am to emphasize

\footnotetext{
358 Ibid.

${ }^{359}$ P. H. G. Scott to F. E. V. Smith, 31 May, 1954, TNA: CO 554/1269.
} 
that this request is in no sense an attempt to take advantage of the present situation and public interest in this country and in the United Kingdom in Mokwa." ${ }^{360}$ Obviously, it was.

The situation was that both the NCG and the CDC had already decided to abandon the project. The NRG had to accept to continue the project because of two reasons. The first reason was that the settlers were subjects of the NRG and the government had a moral obligation to these settlers. The second reason was that the $\mathrm{NRG}$, for some unexplained reason, seemed to be convinced of the experimental value of the scheme even though its director of agriculture had argued against continuing the scheme. If the scheme was not continued, it would have been a public embarrassment to the NRG, which had raised the hopes of the people on the value of the scheme, and also the technical experts who had created the program and had believed that it was going to work. Although the abandonment of this project would have created a public relations problem for the $\mathrm{CO}$ which would have had to deal with stories of abandonment of another set of settlers in a settlement scheme they were associated with, the $\mathrm{CO}$ would have been fine with the scheme closing because the Labour Party was defeated in 1951. The Conservative Party was in government and they were opposed to public sector development.

Though the NRG was making a request for CD\&W funds on the eve of the official handover of the scheme, the handover still took place as planned. On the $1^{\text {st }}$ of June, 1954, the CDC and the NRG handed over control of NAP to the NRG. A day later,

\footnotetext{
${ }^{360}$ Ibid.
} 
the NRG wrote a letter to the $\mathrm{CO}$ requesting for a grant to cover cost of continuing the project. Dick Gresswell, a Nigerian official who was back in Britain on holiday visited the $\mathrm{CO}$ to discuss the letter. He met with two officials there. Three main points emerged from that meeting. He was told that it was contrary to the existing policy for CD\&W funds to be used to rescue $\mathrm{CDC}$ projects. The second point was that there was no parliamentary authority that permitted the Treasury or the CO to give CD\&W funds after the end of $1955 / 56$. This is because the 1945 Act was for a ten-year period. So, there was no need to ask for grants for the recurrent expenditures for the next five years. And the final point was, "Provided that H.M. Treasury agree that the new Mokwa project is eligible for C.D. \& W. assistance, the probable ruling by the Colonial Office will be that costs, ever and above the Regional contribution to the end of $1955 / 56$, must be met from balances in Nigeria's current territorial allocation."361 While the CO did say they had not heard anything from Nigeria regarding the proposed grant that the NRG was requesting, they did agree to approach the Treasury and to inform them that Nigeria would be making an application for assistance for the NAP scheme effective $1^{\text {st }}$ of June 1954. Gresswell's take away from the meeting was that the $\mathrm{CO}$ was expecting a new plan that would lay out what the NRG intended to do at Mokwa and how that fitted into the Ten Year plan and why it was not included before. ${ }^{362}$ Given that the $\mathrm{CO}$ was expecting the NCG to communicate with them in reference to grants for the Mokwa scheme, the Acting Governor of Nigeria sent a letter to the S of S on the $29^{\text {th }}$ of June, 1954 making a strong case for assistance to the NRG for the NAP. Most of the letter laid out the history of the

\footnotetext{
361 Dick Greswell to Peter Gibbs, 18 June, 1954, NNAK: 151D.

362 Ibid.
} 
scheme and re-echoed the same arguments, and sometimes the same language, in the letter of the financial secretary of the NRG on the $31^{\text {st }}$ of May 1954 . The acting governor concluded his letter by writing:

I shall therefore be grateful if you will give consideration to the possibility of making available assistance from Colonial Development and Welfare Funds to the Northern Regional Government bearing in mind the fact which your Agricultural Adviser has pointed out and which was contained in your saving No. 111 of the $14^{\text {th }}$ of January, 1954, that the scheme stands a chance of success and should make invaluable contribution to the Agricultural development of Nigeria provided it is not expected or required to show a profit in the nearest future. $^{363}$

It is interesting how they were using the words of the Secretary of State as a way of convincing him to provide support for the scheme. In his reply, the S of S, Lyttleton accepted to consider an application for assistance from the CD\&W funds without making any commitments. He, however, informed the Acting Governor that should the application be approved, the money had to be found from within the allocation that had been made to the Nigerian territory. Money would not be sourced from other areas of the CD\&W fund. ${ }^{364}$ The problem the NRG faced was that the CD\&W fund was coming to the end of its ten-year period. The NCG was also not committed to using the funds that were meant for the whole of Nigeria for the NRG. ${ }^{365}$

\section{NAP under the NRG}

After the NRG took over the scheme, the scope of operations was reduced as had been planned prior to take over. Palmer, the agricultural engineer was asked to list all

\footnotetext{
${ }^{363}$ Acting governor of Nigeria to Lyttleton, 29 June, 1954, TNA: CO 554/1269.

$364 \mathrm{~S}$ of $\mathrm{S}$ to Acting Governor, 4 August, 1954, TNA: CO 554/1269.

365 The archival materials both in Nigeria and in London that I have been able to access do not tell us whether or not the NRG received the money.
} 
equipment available and to indicate which ones were required to run the project for the meantime. Other equipment was to be transferred to other stations or sold. ${ }^{366}$ The NRG was also prepared to sell some of the buildings in Mokwa that they felt were not going to be useful for the project. Unlike the old grandiose plan to establish a big settlement scheme, the scheme under the control of the NRG was much reduced and was truly an experimental and pilot scheme. What was happening at this time was what should have happened in 1949 when the scheme was conceived. In a meeting held on the $7^{\text {th }}$ of June 1954 by some of the senior staff of the Agricultural department, ${ }^{367}$ it was agreed that only a minimum experimental work should be carried out at the initial stage in order to assess the "possibility of extending the working season." It was also decided that parts of the Demonstration farm should be used for experimental purposes. For the next planting season, the Project was to be prepared to cultivate not more than 3,000 acres and not less than 1,500 acres. $^{368}$ This figure was a far cry from the project's initial goal of cultivating 65,000 acres. The acres that they were projecting to cultivate were even smaller than the 8,684 acres that they had cleared and were planting at the end of 1952. Capping cultivation at 3,000 acres was truly a step toward cutting cost and using the project purely for field trials and experimentation. After the NRG took control of the project, the emphasis was on planting guinea corn, soya beans, groundnuts, and cotton. The new scheme had fewer settlers. It had only about 90 farmers that were settlers in 1955 . In August of 1955, the farmers were debited with the cost of cultivations, cash advances and

366 W. Matthewson (AG. Principal Agricultural Engineer) to Director of Agriculture, Northern Region, 15 June, 1954, NNA: K151D.

367 Present at the meeting were the acting assistant director of agriculture, the acting principal agriculture engineer, the production officer and the agriculture engineer. The managers of the project remained European but now working for the NRG.

368 Minutes of meeting held at Mokwa, 7 June, 1954, NNAK: 151D. 
the value of guinea corn that was supplied to them as food. This amounted to about $£ 11,546.10$. Farmers then sold their produce to the NRG. The NRG did not expect it to be profitable anytime soon. It was seen as an experimental station even on the eve of Nigeria's independence. In the post-colonial period, a college of agriculture was built in the Mokwa area and the area remains a strong agriculture region. NAP never became a huge success in mechanized rural agriculture as was envisioned, but it was successful as an experimental station.

\section{Problems with NAP}

Residents of Manchester, United Kingdom woke up on the morning of the $8^{\text {th }}$ of July, 1954 to see a big headline in their local paper, "ANOTHER GROUNDNUTS SCHEME Failure in Northern Nigeria." The article went on to report that the Niger Agricultural project, Mokwa, which was initiated in 1949 with colonial development and welfare funds, sought to develop an area of over 2,000 square miles, but it had to be wound up only after developing a little more than 8,000 acres. The story concluded by making references to the failure of the Tanganyika groundnut scheme. ${ }^{369}$ The failure of this project was a source of embarrassment for the British as they were still living in the shadow of another failed development scheme, the East Africa Groundnut scheme. The important question that needs to be answered is why did NAP fail?

The first problem with this scheme is in its initial planning. This scheme started without any extended field trials. The Faulkner and Mackie agricultural policy in Nigeria since the 1920s had insisted on extensive field trials before schemes were to be carried

369 "Another Groundnuts Scheme Failure in Northern Nigeria," Manchester Guardian. 
out. This was not the case with NAP. Given the proportion of this scheme, why were there no field trials? There were no field trials to truly determine if the location was good for agriculture. The only considerations were the fact that there was good water supply, high rainfall and easier evacuation routes. ${ }^{370}$ Like the East Africa Groundnut Scheme, the CDC and the colonial state did not resort to any field trials because there was a need to develop export industries in Africa quickly. The scheme was rushed because Britain needed foreign exchange to deal with its balance of payments. The scheme also needed to be done quickly to help pay for Britain's post-war reconstruction. There were limited experiments that were carried out in the demonstration farm that was run by the company but these were on the "the use of fertilizers and variety trials." 371 No one had a scientific knowledge of which seeds were going to be more productive in the settlement. Both the $\mathrm{CDC}$ and the colonial state were in a rush to start this scheme that was started before the managing company and board was formed. ${ }^{372}$ On one hand, the CDC argued that the scheme was not a financially profitable venture but a social experiment and on the other hand, they were rushing the scheme.

There was a founding hope that NAP might be successful. Rackhouse revealed in his confidential memo that,

a decision was taken about the lay-out of the scheme during a five minute ride over it in an aeroplane and grave mistakes resulted. An aerial survey was undertaken at great expense of the whole of Kontagora Emirate whereas a close contoured plan of the pilot area was required... Insufficient attention was paid to the question of water supply, it being assumed that the provision of water at

\footnotetext{
${ }^{370}$ A CDC Scheme for the Agricultural Development of an Area near Mokwa, Nigeria (Niger Agricultural Project, Ltd), Report from NCG to Lyttleton, 29 June, 1954, TNA: CO 554/1269.

371 Susannah Bolton, Eddie Arthur, William Buhler, et. al., Science Agriculture Research: A Compromised Participation (London: Earthscan Publications, 2002), 55.

${ }^{372}$ Memorandum by D.H Parkinson, 14 March, 1945, TNA: CO 583/271/4.
} 
the bottom of a well was adequate for settlers who had never pulled a skin of water from a well in their lives. ${ }^{373}$

Rackhouse, the Resident of Niger at the time, was very critical of the scheme. This scheme was neither his idea nor that of other local officials. It was a project that came from the outside, in this case the metropolitan government, and it went completely against the local tradition of careful research and incremental change. Not only was the scheme an outside project but it was also micromanaged by the central organization of the CDC in London. Rackhouse argued that the central organization tried to micromanage the project in order to get quicker returns. They insisted on clearance and cropping targets and wanted immediate returns for the money invested in the scheme. He wrote in the secret memorandum:

by insisting on clearance and cropping targets and immediate returns for their money they [CDC] caused a loss of some $£ 20,000$ to $£ 30,000$ over stumping, breakages of machinery and waste of manpower. These stumps are still being removed at great expense and there is still a large area to do. They were responsible for sowing up by direct labour the newly cleared land with guinea corn, thus incurring a great loss both in money and prestige when it failed. ${ }^{374}$

The management of the scheme was pressured for quicker returns. ${ }^{375}$ This meant that the management could not have long term planning and execution in view but would have to resort to options that would raise money immediately. Investigations and proper trials were skipped.

The third major problem this scheme faced was that of settlers. This problem plagued the scheme from the onset. A political decision was made that for the first settlement, settlers should only be drawn from the Mokwa area. The reason behind this was the fear

\footnotetext{
${ }^{373}$ Memorandum by M. V. Rackhouse, 2 April, 1953, TNA: CO 554/458.

${ }^{374}$ Ibid.

${ }^{375}$ Ibid.
} 
that the local people would oppose settlers being brought in from other regions of the country and this would create problems for the execution of the scheme. Many immigrants, such as Igbo people of Eastern Nigeria who were residing in the Northern Region and had provided the first labor for the scheme, were prevented from participating in this settlement. Even for the rest of the settlements, the decision was made that settlers should only be drawn from the Northern Region. The reason was because of the contempt that northerners had toward the southerners. Settling southerners in this region would seem like the southerners were taking over. The north was not able to supply enough manpower for the efficient execution of the scheme. For a scheme that involved the resources of the whole of Nigeria, there shouldn't have been tribalism in the allocation of settlements. Settlers should have been brought from wherever in the country there were willing people to work. NAP was plagued by the same problems that besieged the Office du Niger. Like the Office du Niger, Mokwa was a sparsely populated area. The initial settlers were from the local area but as the project expanded, recruitment of settlers became a major problem that preoccupied the French. ${ }^{376}$ As settler recruitment become a major problem, the French started using coercive recruitment techniques. For NAP, by the middle of 1952, there were already concerns about its prospects as there were issues attracting settlers and the first year's outcome wasn't satisfactory. The Ndayako settlement was a great failure from the onset. There was no mechanism to insure that these settlers were qualified to be awarded land. Most of them were attracted by the desire to get land for nothing. It was later discovered that a large number of these settlers were not good farmers and were not interested in doing their share of the work. Most of

376 Beusekom, Negotiating Development, 57. 
these settlers decided to leave by the end of 1952, after the failure of the groundnuts and an aggressive collection of the two-third proceeds by the company. ${ }^{377}$ At this point, only one settlement had been fully established and there were hopes that the second settlement would be fully established by the end of 1952; and then the third settlement in 1953. By March of 1952, only one and a half settlements had been achieved. In discussing the quality of settlers to the settlement, Baldwin writes that when the department of labor in Kaduna was asked to send all available men of Northern Provinces or adjacent French territory who were seeking work. The 225 men who arrived were unimpressive:

Some were ex-Servicemen, who appeared never to have wanted work, let alone agricultural work. Others were obviously thoroughly unfitted for hard manual work - one had a withered leg and could not walk without the help of a stick, another had advanced syphilis, two had been discharged unfit from the Army and four or five were aged about 80 . Within three weeks, desertions had been so heavy that only eighty-seven remained. Shortly afterwards most of the others left, some of them being sentenced to imprisonment by native courts as rogues and vagabonds for idling round railway stations. ${ }^{378}$

By the end of June, 1952, 24 of the original 78 settlers in the Ndayako settlement had been replaced and in order to achieve the standard of cultivation desired, 24 more settlers needed to be replaced. By September of 1952, four more farmers were dismissed from the Ndayako settlement and farmers were resistant to hoe areas for the cultivation of groundnuts and Bambara nuts. As a result of this, the company was forced to take over the direct cultivation of 260 acres of land. ${ }^{379}$ Losing more than half of the settlers in the first year of the settlement meant a great waste of time and resources. The settlers were not familiar with the type of farming they were being introduced to. They had to learn,

\footnotetext{
${ }^{377}$ Memorandum by M. V. Rackhouse, 2 April, 1953, TNA: CO 554/458.

378 Baldwin, The Niger Agricultural Project, 39.

379 Colonial Development Quarterly Report on Schemes in Operations for quarter ended 30 September, 1952, TNA: CO 7304/52.
} 
and the hope was that they could get better in time thereby leading to more positive results. Continually replacing the farmers meant that no significant experience was gained. New settlers had to be trained. This meant expending a lot of time and resources. The problem of settlers is one that continued to plague the scheme throughout its existence. To attract volunteer settlers was a problem because the people in the region were not starving for land and they considered where they were already farming as fertile land and there was no reason for them to abandon that to embrace a new form of farming that had not been tested and proven to be more beneficial than their own ways bequest to them by their ancestors. Thus, finding settlers became a perennial problem and that was the reason the settlements were not being filled according to schedule. Before the end of 1952, the company was forced to replace ten unsatisfactory settlers and nine more had surrendered their holdings. ${ }^{380}$

Another problem that the scheme faced was mechanical. The tractors that were used were not suitable for the land. Based on the experiences acquired by the engineering department of CDC from the East African Groundnut Scheme, they decided against mechanized clearing of Mokwa. They ruled out the use of the 80 horsepower bulldozers. Their understanding was that only 130 horsepower bulldozers would be suitable. These were not readily available in Nigeria. They needed to be shipped from the United States and it was going to take several months, which meant the project was going to be delayed for several months. This was also going to significantly increase the budget of the project. ${ }^{381}$ At the end of the day, they used the equipment that was readily available, the

\footnotetext{
380 TNA: CO 146/71/52.

381 Baldwin, The Niger Agricultural Project, 105.
} 
Fordson Major diesel tractors and Ransomes Dragoon disc ploughs. These machines suffered mechanical problems, and they had to wait some times for months for spare parts to arrive from overseas. Baldwin writes that the "delays in the arrival of machinery and parts was, throughout the period of operation of the scheme, a great administrative problem. In April 1952 two senior officers had to travel personally from Mokwa to Lagos to search for cases of spares which had been mislaid somewhere on Apapa wharf ... Matters were not helped by the inefficiency of the postal system. The delivery of letters and packets, and even the supply of stamps was irregular. Parcels clearly marked Mokwa were sent to Minna, 140 miles away." ${ }^{382}$ The mechanization aspect of the project created so many problems that they had to resort to hand tools. At the end, mechanization failed and the traditional African methods triumphed.

Another problem that plagued this scheme was the lack of consultation of local knowledge. There is no evidence that the local people were consulted in the planning process of the project. The scientific experts carried out the survey of the area and determined the location of the settlements and the property in the settlement. The contributions of the local emir or leaders were very marginal. They served in the advisory board but their role was limited to recruiting settlers and disciplining them. If the local people were consulted, the way the residential quarters of the farmers were built would have been done differently. The houses were built facing the roads. This style of building was alien to the local people. They built their houses facing each other, creating compounds. They saw this style of construction as a means of social bonding. The

382 Ibid., 114-15 
settlements never felt like home to the settlers and thus many of them lived in Mokwa city and came from there to their farms, thereby defeating the purpose for which the houses were built. The locals also understood the weather patterns and the appropriate times in which to plant their seeds. The technical officers never sought this knowledge from the locals.

Another problem that marred this project were the incentives. The settlers received one-third of their produce, while the company took two-thirds of the produce. The settlers did not see any incentive to cultivate more because they felt that Europeans were exploiting them. Based on the calculations, the average African farmers who did not live in the settlement and were not part of the scheme cultivated about four acres of land a year and earned an average income of $£ 25$ a year. They did this while having the choice to cultivate whatever they wanted to. A settler who was forced to cultivate about 24 acres of land still made about the same income. As Baldwin argues, "It is clear that in the first two years the average incomes actually earned by the settlers were only a half to threequarters of what the average local farmers were obtaining on their much smaller plots without the aid of mechanical equipment." ${ }^{383}$ This was also part of the reason why many of the settlers chose to desert the settlement. Given that they could make as much money cultivating a smaller portion of land without the strict orders of the Europeans, they chose freedom over living in the settlement. The morale in the settlement was very low and the settlers did not believe in the scheme. For a scheme of this nature to work, the settlers must be committed to the project. In the case of NAP, they were not. The settlers could

383 Ibid., 79. 
not be forced to work either because there was no proportional punishment. Expelling them from the settlement had little or no negative impact on them. They returned to their normal lives with their families.

The problems that plagued NAP were the same that many other large agricultural settlement schemes experienced in this period. These problems were lack of local knowledge, failure of mechanical equipment, settler unrest or high turnover, etc. All of these problems could be explained with one term, "poor planning." The desire to produce quickly blinded them to the need to carry out extensive field trials. Even the Gezira scheme, which was hailed as a success story and upon which NAP was fashioned, took several years of incremental trials and expansion. NAP ignored thirty years of wisdom that was propagated by the agriculture department in Nigeria. What we learn from the failure of this scheme is that "any successful agricultural extension scheme based on large-scale, highly capitalized methods, depends initially on adequate knowledge about the characteristics and significance of tropical conditions, about the theory of this kind of development, and about the complex conditions existing in the actual area in which the development is contemplated. Secondly, any kind of agricultural innovation should proceed slowly and carefully, for the object of rural development should be simply to graft on to indigenous life the things that it lacks. ${ }^{384}$ Development schemes are only successful in as much as the planning is done properly. Proper planning takes not only an assembly of technical experts and colonial bureaucrats, but it has to involve the local people for whom the process is intended to benefit. It is also a mistake for "experts" to

\footnotetext{
${ }^{384}$ B. W. Hodder, Economic Development in the Tropics (London: Methuen \& Co. Ltd., 1968), 139.
} 
assume that the ways of the locals are primitive and foolish. As I have argued severally in this chapter and in the prior chapter, there is sense to peasant agriculture. Their ways of cultivation may not be advanced in the mechanized sense but they have generations of wisdom we can learn from. Some of the mistakes of NAP were those that could have been easily dealt with if the designers and executors of the scheme consulted both the native wisdom and the wisdom of the agriculture department in Nigeria.

\section{Conclusion}

The failure of this scheme and many other similar schemes during the colonial period was not a requiem to these schemes. The $1950 \mathrm{~s}$ were the eve of independence for most African nations. Ghana's independence was in 1957 and Nigeria's independence was in 1960. The nationalists and the educated elites saw mechanization as the way forward for their nations to prosper economically. Rather than allowing these schemes to die or to replan them from the scratch, the emerging African leaders expanded these schemes or created new ones. They believed that food security and economic development meant a massive take over of agricultural development by the government. They did these by pouring more financial resources (usually with borrowed money from international financial organizations) into these schemes. Some of the European expatriates who managed these failed schemes continued to be technical advisers under the new regime. NAP remains a good example. Though it was seen as a failure in early 1953, the CDC and the company did not just abandon it and walk away. They had to look for a new trustee for it and this was the NRG. The scheme would continue into the post- 
independence period with modifications. But as I have argued above, this scheme was plagued by problems and did not fulfill the goals for which it was conceived. 


\section{CHAPTER FIVE}

\section{Recreating the Nigerian State: The National Development Plan, 1962-1967}

\section{Introduction}

Though colonial rule ended in Nigeria in 1960, development planning did not end. The emerging Nigerian leaders saw development as an instrument for dispensing the benefits of self-rule. Between 1955 and 1962, the different regions of the country and the federal territory wrote and attempted to implement different development plans. These plans suffered a starvation of funds and were poorly implemented. Some of the major schemes that were initially billed to be part of the 1955 development plans became part of the 1962 plan. Though the 1955 plans offer a segue between development in the colonial and postcolonial period, it is not my goal in this work to analyze those plans. The goal in this chapter is to analyze the planning process that resulted in the 1962 national plan.

Unlike the 1945 colonial plan, the US and international organizations were a major factor in the design and implementation of this plan; and African agency was stronger than in the former plan because Nigeria was now an independent country. I will show that the independence of Nigeria and the active presence of the United States and other international organizations and foundations such as the World Bank, the Ford and Carnegie foundations did not signify a break in development 
policy. In fact, the same policies, most especially in the agricultural sector, were continued.

This chapter will look at how American social scientists such as Walt Rostow and his compatriots associated with the CIS were motivated by modernization to influence the US government to financially support development work in Nigeria with the goal of recreating it into a modern country in the image of America. I will argue that despite the bold development prescriptions of modernization theory, in practice, it continued late colonial era development policies such as the development of rural agriculture. This study will also show that the US government's acceptance of modernization theory and its willingness to provide substantial financial aid to the 1962 plan was not completely altruistic but was stimulated by the Cold War and America's desire to align itself economically with the most populous African nation, with the aim of creating a new market for American goods and businesses.

\section{The Rise of Modernization Theory}

The post- World War II period witnessed enormous changes in the world and American social scientists were in a mission to bring the gospel of modernization to the developing world. Nils Gilman argues that these social scientists suddenly found modernization a seductive category during this time because of three factors: decolonization, the availability of resources, and the Soviet influence that was 
moving beyond Europe to former colonial areas. ${ }^{385}$ During his inauguration speech of 20 January, 1949, President Harry Truman in his fourth point gave his foreign policy as follows:

We must embark on a bold new program for making the benefits of our scientific advances and industrial progress available to the improvement and growth of underdeveloped areas. More than half the people of the world are living in conditions approaching misery. Their food is inadequate. They are victims of disease. Their economic life is primitive and stagnant. Their poverty is a handicap and a threat both to them and to more prosperous areas. For the first time in history, humanity possesses the knowledge and skill to relieve suffering of these people. The united States is pre-eminent among nations in the development of industrial and scientific techniques. The material resources which can afford to use for assistance of other peoples are limited. But our imponderable resources in technical knowledge are constantly growing and are inexhaustible. ${ }^{386}$

Later that same year, the Truman proposed his "Fair Deal" domestic agenda in his State of the Union speech. This agenda proposed modern liberal policies such as more federal aid for education, universal health care, and full employment. This was the American version of the "welfare state" that was at the very same time being introduced in Europe. Such promises made by Truman were, however, defeated by the conservative dominated congress. The failure to create a modern liberal state as envisioned by some of these social scientists ${ }^{387}$ internally within the US, led them to turn outward. They sought to achieve externally what could not be fully achieved in the US, by recreating American style society around the world. Decolonization provided an opportunity to the fulfillment of this dream. The partition and

\footnotetext{
385 Gilman, Mandarins of the Future, 32.

386 Department of State Bulletin, 30 January, 1949, 123.

387 Some of these social scientists were Walt Rostow, Lucian Pye, David Apter, and Gabriel Almond. Three academic institutions were at the forefront of this theory: The Social Science Research Council's Committee on Comparative Politics, Harvard University's Department of Social Relations and MIT's CIS.
} 
independence of India and Pakistan in 1947 inspired many other colonies to seek independence, not only in Asia but also in Africa. The decolonization movement was an attempt by colonial people to free themselves from the imperial grips of the European nations whom they had been under for several decades. In the late 1940s, every African nation with the exception of Liberia and Ethiopia were under some European imperial domination. What was also true during this period was that most of these African nations were moving toward independence.

The rise of the nationalist movements and the concurrent resistance of the people to colonial rule created problems for the European states in their colonial holdings. For their part, the European states emerged from World War II heavily bruised both economically and psychologically and lacked the capacity both in human and economic terms to hold onto empire. As hard as they tried to hold onto the colonies, by the 1950s, it became clear to them that decolonization was in their best interest.

America's unique and vital role during the war placed her in a new position in the world stage. Though President Roosevelt was philosophically opposed to European empire, the administration of Harry Truman and later, Dwight Eisenhower, maintained solidarity with the colonial powers against the nationalist movements until the Suez crisis of 1956 in which the Eisenhower's administration forced Britain to abandon its imperial quest in Egypt. This, as Monica Belmonte 
argues, was a shift in US policy toward colonial rule. ${ }^{388}$ As she argues, US policy toward Africa during the Cold War rested on the assumption that self-determination was not an "unqualified right" but was something to be earned. Drawing upon cultural supremacy and racism, US officials believed that "non-western peoples had to show themselves ready for independence according to western standards." 389 US continuous support of colonial rule was motivated by a racist idea that Africans were not prepared to govern themselves and thus, would be vulnerable to communist influence. ${ }^{390}$ The independence of Ghana in 1957 and the willingness of Ghanaian leaders to deal with the Soviet republic did not assuage the fears of US officials. Belmonte writes, "Washington, dubious of Nigerian fitness for independence, embraced the undemocratic regime the British put in place as likely to preserve Nigerian-UK bonds. If a vigorous Nigerian nationalism was driving the UK from its empire, London still retained enormous power to determine which Nigerians would inherit the colonial state."391

Though the old colonial masters still had their grips on the emerging African nations in the late 1950s, American sphere of influence became greater in most of these colonial holdings. America was present through international funding institutions such as the IBRD, American foundations such as Ford and Rockefeller and a slew of American businesses and technocrats who were giving expert and

\footnotetext{
388 Monica L. Belmonte, "Reining in Revolution: The US Response to British Decolonization in Nigeria in an Era of Civil Rights, 1953-1960," PhD dissertation, Georgetown University, 2003, 7.

389 Ibid., 5.

390 Ibid.

391 Ibid., 9-10.
} 
technical advices to the emerging countries. The American presence in these nations was not to establish formal empires as in the case of the British or other Europeans. Unlike imperialist Europeans, "Americans did not subscribe to the idea that some ethnic or racial superiority gave them the right or indeed the obligation to rule."392 Moreover, American social scientists saw an opportunity to recreate these emerging countries into the likeness of the US. Given that these nations were rich in natural resources, the idea was that if American-style free enterprise was promoted in these places, American businesses would stand to benefit which also means that America would stand to benefit. In the course of their struggle for independence, the nationalist movements in these emerging countries had promised their supporters that the nation would become as modernized as those of their oppressors. What was also true was that this was going to be very difficult to achieve. The emerging political leaders of these nations had neither the economic resources nor the manpower to carry out this vision for their nations. American social scientists stepped in with what Larry Grubbs calls "The Gospel of Modernization." ${ }^{393}$ A key part of this gospel was economic improvement. As Gilman writes, "American social scientists and policy makers proposed economic improvement as a solution to the challenges of decolonization because greater prosperity was one of the few things they felt capable of providing to foreign countries." ${ }^{394}$

\footnotetext{
392 Gilman, Mandarins of the Future, 33.

393 Grubbs, “Bringing 'The Gospel of Modernization' to Nigeria,” 279.

${ }^{394}$ Gilman, Mandarins of the Future, 35
} 
Rhetorically, modernization theory was different from colonial development. In Africa, the British pushed for the improvement of the social conditions of the colonial people through the 1940 and the 1945 CD\&W Acts. What they were attempting to do was too little and too late. Though extensive plans were drawn up to help in this work of development, it was never their intention to provide Africa with both the economic resources and social facilities to bring it on par with Britain. For some of the colonial officials, Africa and Africans were always going to be inferior to Europeans. The proponents of modernization theory, such as Rostow and Marion Levy, saw modernization as a phased and homogenizing process. ${ }^{395}$ Some of these American social scientists actually believed that the conditions of African nations could be changed and Africa could and should become more like America. For them, nations underwent a historical process from primitive, traditional societies to modern societies. They argued that traditional society is bereft of an advanced economic system and is dependent on agriculture. The traditional society is also backward in thinking. ${ }^{396}$ A good example here is how this society deals with gender. A traditional society lacks liberal democracies and social amenities such as good and universal health care, public education, and human rights. What was modern was a direct opposite of what was traditional. The modern state for them was an industrialized state. It afforded its citizens human rights and saw health care

\footnotetext{
395 More on Rostow and his five stages in this chapter. This chapter places emphasis on Rostovian theory because Rostow had great influence on CIS and the work their social scientists did in Nigeria. Marion Levy argued that modernization produced homogeneity. Over time, he argued, societies and us "will increasingly resemble one another because the patterns of modernization are such that the more highly modernized societies become, the more they resemble one another." See, Marion Levy, Social Patterns and Problems of Modernization (Englewood Cliffs: Prentice Hall, 1967), 209.

396 Gilman, Mandarins of the Future, 3.
} 
and public education as rights afforded to every citizen and not things available to a privileged few. This view rested on the assumption that African societies and culture was backward and stagnant and needed to be changed from the outside. Such a view was tendentious toward cultural superiority and arrogance.

Modernization theorists such as Walt Rostow believed that African societies could be moved from traditional societies to modern ones. In their thinking, this process could even be hastened in order to enable these nations to reach that point faster. The way to achieve this was through systematic and scientific central planning. In the 1950 s and 1960 s, most of these theorists ${ }^{397}$ worked at policy studies centers and think-tanks where they helped to craft plans of modernization for emerging nations. Their goal was to make these nations look like the United States and not the Soviet Union or, after 1949, China. This was a wholesale marketing of American culture. What was sold to these nations was not only the American political system but also her economic, social and cultural system. What was traditional in these nations was to be replaced with what was modern. There needed to be a break with what was considered traditional norms. ${ }^{398}$ To achieve this goal, it was not important for these scientists to painstakingly understand the culture of the people and to try to work from within that culture. Their arrogance convinced them that the inherent culture of the people was no longer suitable for the modern world. Such a culture needed to be replaced with what was modern. The

\footnotetext{
397 Some of these theorists were Bert Hoselitz, Gabriel Almond, David Apter, Karl Deutsch, Daniel Lerner, Lucian Pye, Edward Shils, and Talcott Parsons.

398 Frank Ninkovich, Modernity and Power: A History of the Domino Theory in the Twentieth Century (Chicago: University of Chicago Press, 1994), xiii-xiv.
} 
failure of modernization theory can be attributed, at least partly, to its failure to understand and work from within the cultural system of the people. This was a major problem with the 1962 development plan as we will see later. Unlike the colonial development models espoused by people like James Mackie which insisted on the understanding of local conditions and culture, the 1962 plan was designed by foreign experts who were ignorant of the ethno-cultural rivalries and politics of Nigeria.

\section{The Advent of Modernization Theory in Nigeria}

One African nation that was important for the evangelists of the modernization gospel was Nigeria. Two American social scientists, Arnold Rivkin and Wolfgang Stolper associated with the CIS made unique contributions toward Nigeria's 1962 development plan. These men, together with CIS, used Nigeria as a laboratory for the experimentation of Cold War-era modernization theory. ${ }^{399}$ The appeal of Nigeria for these men, and in fact for CIS, stemmed from the fact that Nigeria was Africa's most populous nation and its emerging leaders exhibited moderate political views. To Rivkin, a Nigeria recreated in the American image could serve as a model to other African nations at a time when voices of communism were raging in the continent. However, the US was interested in keeping communism from taking hold in Nigeria because this would have been disastrous to the US economic goal of building more capitalist-oriented economies throughout the continent. Modernization gospel came to Nigeria not only because of the fear of

399 Grubbs, “Bringing 'The Gospel of Modernization' to Nigeria," 283-84. 
communism but also because of the belief that Nigeria could be built into a modern economic society with a liberal democracy.

CIS played an influential role in US government policy circles because it was a center whose very founding was inspired by the government. At its core, CIS's mission was to fight against communism and to spread American style democracy around the world. The Truman administration established CIS in the hopes that its work would help to counteract the spread of communist propaganda around the world, which was very successful in swaying people to its political ideology. The Voice of America, ${ }^{400}$ which was used by the US government as an instrument to reach the people of Eastern Europe and the USSR, was failing to achieve its goal. As Blackmer notes, Soviet "jamming of Voice of America radio broadcasts behind the Iron Curtain had by 1949 become so effective that only about five percent of VOA's Russian language transmissions were getting through to Moscow. In the summer of 1950, Undersecretary of State James Webb turned to MIT for help."401

MIT was expected to help the US government find technical ways in which to stop the jamming of the radio signals. The project was called Project Troy402, "the idea being to smuggle a Trojan horse bearing the American vision of the world into

\footnotetext{
400 The Voice of America (VOA) was founded in 1942 as a shortwave radio station to broadcast commentary (propaganda) about the war. The first live broadcast was on February 1, 1942 and it was to Germany.

401 Donald L. M Blackmer, The MIT Center for International studies: The Founding Years, 1951-1969 (Cambridge, Massachusetts: MIT Center for International Studies, 2002), 4.

402 This was a project of the State Department. It was codenamed Troy after the wooden horse that the Greeks are said to have hidden their army for them to secretly gain entrance into Troy. The idea of the project was to deal with both the technical issues and political warfare that was necessary for the US to gain entrance into Eastern Europe and USSR.
} 
the enemy camp." ${ }^{403}$ The President of MIT, James Killian, and the Dean of Humanities and Social Studies, John Burchard, were interested in the project on the condition that they would tackle not only the technical aspects but also the broader communications issues. This meant that social scientists were going to be included as part of the research. Webb agreed to the condition and within a few days Killian wrote to inform him of MIT's desire to proceed with the project. The study was supposed to last for three months. MIT did not have all the resources in the social science department to help with the project and so Killian sought help from Paul Buck, the Harvard provost. Four faculty members were recruited from Harvard to help with the project. ${ }^{404}$ A year after Project Troy was completed and the report submitted, Max Millikan, who was an active member of Project Troy, was named the Director of CIS. ${ }^{405}$ CIS was created in January of 1952 and its initial seed money came from the CIA. The center would also receive a grant of $\$ 875,000$ from the Ford Foundation as initial moneys to help it with its communications research programs. Other foundations, such as Rockefeller and Carnegie, would also contribute funds to the center within the first decade. ${ }^{406}$ The creation of the center was the brainchild of the participants of Project Troy. The first research project of the center actually started in the fall of 1951 with Walt Rostow supervising a study on "Soviet

\footnotetext{
403 Blackmer, The MIT Center for International studies, 4.

404 These were Edward Purcell, a physicist; Jerome Bruner, a psychologist; Robert Wolff, a Russian historian; and Clyde Kluckhohn, an anthropologist.

405 Blackmer, The MIT Center for International studies, 5-8.

406 Gilman, Mandarins of the Future, 158.
} 
Vulnerability." Rostow's study, which was completed in eighteen months, resulted in the publication of his book, Dynamics of Soviet Society. 407

\section{Walt Rostow and the Modernization Gospel}

Walt Rostow was born to Russian Jewish immigrants to the US on the $7^{\text {th }}$ of October, 1916. He graduated with a bachelors and doctorate degree in Economic history from Yale University in 1940. During the Second World War, he worked in the Office of Strategic Services. After the war, he worked for the State Department as an assistant chief of the German-Austrian Economic division. In 1947, he participated in the development of the Marshall Plan in his role as the assistant to the Executive Secretary of the Economic Commission for Europe. Between 1951 and 1961, he was professor of Economic history at MIT. While in this role, he was also advisor to President Dwight Eisenhower on economic and foreign policy. ${ }^{408}$

Rostow was one of the most influential economic historians of the center. Rostow's economic theory had a great impact on the work of the center in the developing world. One of his most influential books is his 1952 work entitled The Process of Economic Growth. This book, which expounds the central tenets of modernization theory, links economics to other social sciences. This theory expands beyond development economics to look at modernization as a total social, political, cultural and economic transformation, in which cultural attitudes and beliefs are

${ }^{407}$ Blackmer, The MIT Center for International studies, 21-26. See Walt Rostow, Dynamics of Soviet Society (Cambridge, MA: MIT, 1951).

${ }^{408}$ Later on, Rostow would work for both the Kennedy and Johnson administrations. More on this later in this chapter. 
important in triggering the "take off" to sustained economic growth and investment. Rostow approached this by introducing six propensities. These are, (1) propensity to develop fundamental science (physical and social); (2) propensity to apply science to economic ends; (3) propensity to accept innovations; (4) propensity to seek material advance; (5) propensity to consume; and (6) propensity to have children. ${ }^{409}$ For Rostow, "[t]hese propensities depend on the attitudes, motives and aspirations of the people which in turn depend on the previous political, economic and social factors. The total working force and the magnitude and productivity of the capital available in the economy are the prime movers in the process of economic growth." 410 The six propensities that Rostow mentioned were aspects of culture that were necessary for the economy. For example, the labor that was available for the economy of any society was dependent on the birth and death rate. These propensities are interconnected and had an impact on economic performance. His position, as Gilman remarks, "synthesized cultural and technological determinism: technology was the ultimate driver and definer of modernization, but it was culture that determined how a society took up that technology."411

A criticism that befell Rostow's economic theory was that it failed to explain root causes of historical change. Why would a society shift from one economic stage

\footnotetext{
409 W. W. Rostow, The Process of Economic Growth (New York: W. W. Norton, 1952), 13-13.

410 Kulwant Rai Gupta, Economics of Development and Planning: History, Principles, Problems and Policies (New Delhi: Atlantic, 2009), 192.

411 Gilman, Mandarins of the Future, 162-63.
} 
to the next? Rostow never solved this problem that his theory faced. ${ }^{412}$ Rostow's 1960 work, The Stages of Economic Growth: A Non-Communist Manifesto, ${ }^{413}$ was an important work for adherents of modernization theory. In it he argued that economic modernization happened in five stages: the traditional society, the preconditions for take-off, the take-off, the drive to maturity and the age of high mass-consumption. ${ }^{414}$ Social scientists associated with CIS saw this model as one that could be replicated in the developing world. The work of CIS in Nigeria was aimed at moving Nigeria through these stages of development. It was believed that these stages could be moved through quickly thereby leading to a modern society. Rostow's book was very influential even to American politicians who saw communism as a threat. Both John F. Kennedy and L. B. Johnson were great admirers of Rostow's work, seeing it as a prescription against communist influence. David Milner writes that, "[t]hrough the 1950s Senator Kennedy was impressed by Rostow's intellectual ability, his productivity, and the originality with which he approached the then politically charged question of U.S. foreign aid." ${ }^{415}$ Rostow argued strongly in his book that the US should provide foreign aid to developing nations to enable them to achieve a capitalist economy and a liberal democracy. Rostow also believed that properly channeling of U.S. foreign aid toward developing nations would help stem the influence of communism. After the election of John F.

\footnotetext{
412 Ibid.

${ }^{413}$ W. W. Rostow, The Stages of Economic Growth: A Non-Communist Manifesto (Cambridge: Cambridge University Press, 1990).

414 Ibid., 4-10.

${ }^{415}$ David Milner, America's Rasputin: Walt Rostow and the Vietnam War (New York: Hill and Wang, 2008), 9
} 
Kennedy as president, Rostow was appointed deputy special adviser for national security affairs. Milner says "Rostow assumed White House responsibility for U. S. policy toward Southeast Asia and, indeed, for most of the world east of Suez." ${ }^{416}$ Later, Kennedy would move Rostow to the Policy Planning Council at the State Department. After the assassination of Kennedy, President Lyndon Johnson appointed Rostow as his national security adviser and Rostow helped guide his policy in Vietnam.

The rise of Rostow through the echelons of the US government meant the influence of modernization theory increased around the world. Rostow had the ear of Kennedy and Johnson and he helped direct a lot of US foreign aid during their administrations. Nigeria was one of the beneficiaries of US foreign aid, and, in fact, the country was one of the largest recipients of aid from Washington. The aid given to Nigeria was intended to help implement the country's first national development plan which was crafted with the help of Rostow's former colleagues at CIS.

\section{The Independence Plans, 1955 to 1962}

Beginning in the early 1950s, Nigeria witnessed the growing presence of international organizations such as the IBRD, the International Cooperation Administration (ICA), which was the precursor to the United States Agency for International Development (USAID). In September of 1953 the IBRD made an economic mission to Nigeria on the request of the governments of Nigeria and the

416 Ibid. 
United Kingdom. The task of the mission "was to assess the resources available for future development, to study the possibilities for development in the major sectors of the economy and to make recommendations for practical steps to be taken, including the timing and co-ordination of developmental activities." ${ }^{417}$ This international mission comprised of ten full-time members and five part-time consultants. The Food and Agriculture Organization nominated three of the experts on agriculture. Members of the mission were from the Netherlands, Australia, France, Italy, Turkey, the United Kingdom and the United States. ${ }^{418}$ After having spent about three months in Nigeria, the mission prepared an integrated program of development for Nigeria. In this over six hundred pages program report, it identified as an obstacle to Nigeria's development, the lack of "technical and managerial skills and the knowledge of the country's resources necessary to carry out an accelerated program of development." ${ }^{419}$ To resolve this problem of skills shortage, a recommendation was made that personnel be recruited from overseas while Nigerians must be trained. ${ }^{420}$ The report also called for the development of agriculture, transportation and the university system.

Twenty days after the IBRD mission submitted this integrated plan of national development, Nigeria became a federation on October 1, 1954. The implications of this was that the regional governments could either adopt or reject

\footnotetext{
417 World Bank, The Economic Development of Nigeria: Report of a Mission Organized by the International Bank for Reconstruction and Development at the Request of the Governments of Nigeria and the United Kingdom (Baltimore: John Hopkins Press, 1955), vii.

418 Ibid.

419 Ibid., 3.

420 Ibid., 4.
} 
the recommendations. Adebayo Adedeji wrote, "Although each government made references to the mission's work, the five development programmes of the governments were far from constituting an integrated, mutually consistent and coordinated development programme." 421 The five plans of development resulted from the half-hearted attempts of the different governments to create their own plan. The federalization of the government meant that there were now four different governments and the Federal Territory: the Northern Regional Government (NRG), the Western Regional Government (WRG), the Eastern Regional Government (ERG), the Southern Cameroons and the Federal Territory of Lagos. All of these governments had their own development programs. The different plans from the different governments took different directions. Both the federal government and the WRG prepared complete plans for the five year period beginning in 1955 and ending in 1960. The NRG only published a policy statement on the development program and then in 1958 revised it to extend to 1962. The ERG, which was experiencing financial difficulties, only published an outline of a development plan projected to cost $£ 5.2$ million. In 1958 the ERG extended its plan to 1962 and increased the capital expenditure to $£ 20.7$ million. ${ }^{422}$

One of the recommendations of the IBRD mission in 1953 was the creation "of a special body to advise on economic policy and to propose, analyze and co-

${ }^{421}$ Adebayo Adedeji, "Federalism and Development Planning in Nigeria" in A. A. Ayida and H. M. A. Onitiri, eds., Reconstruction and Development in Nigeria: Proceedings of a National Conference (Ibadan: Oxford University Press, 1971), 101.

422 Ibid., 100. 
ordinate public investment programs." ${ }^{423}$ This machinery that they recommended was to consist of "an economic secretariat within the federal government, to provide staff services for an economic committee of the federal Council of Ministers." ${ }^{424}$ They also proposed that the different regions should have an economic committee and that "there be created a national economic council in which the federal and regional governments would be represented." 425 The National Economic Council (NEC) was created in 1955 and the Governor-General was the chairman. Later, the federal prime minister became the chairman. In 1958, the council created another development organ called the Joint Planning Committee (JPC) to play an advisory role to the NEC. In 1959, the NEC, recognizing the incoherent and uncoordinated plans in existence, decided that a national development plan be prepared for Nigeria "with the objective of the achievement and maintenance of the possible rate of increase in the standard of living and the creation of the necessary conditions to this end, including public support and awareness of both the potential that exists and the sacrifices that will be required."426

\section{Triangulating Development: Britain, the United States and Nigeria}

As Nigeria was moving toward integrated national development while still under colonial rule, the presence of the US through the ICA, consulate staff and foundations created a complex relationship between Britain, Nigeria politicians and

\footnotetext{
${ }^{423}$ World Bank, The Economic Development of Nigeria, 82.

424 Ibid.

425 Ibid.

${ }^{426}$ Federation of Nigeria, National Development Plan, 1962-68 (Lagos: Government Printer, 1962), 4647.
} 
the US. This relationship is best understood by a statement that was made by British information officer on hearing about the appointment of a USIS official to Lagos in 1955. He said,

...our people in Nigeria ...[who] have a sufficiently delicate task in helping the peoples of Nigeria toward self-government without friction among themselves and in friendship with the United Kingdom [now] have also to contend with the clumsy efforts of an almost completely unheralded American to proclaim the American way of life in the largest of Her Majesty's dependent territories... it seems only too likely that in one way or another he will either offend some section of Nigerian opinion or promote ideas that will tend to throw doubts on British aims and methods. ${ }^{427}$

The complexity of the relationship lay in the fact that the British did not like the Americans or the international organizations meddling in the affairs of the colonies, yet they wanted the US to provide aid to Nigeria. As Belmonte has shown, the American consulate in Nigeria continued to receive their briefings on Nigeria from the British officials. An ICA visitor to Nigeria found out that "in Lagos...the staff appears to be not only too small but inhibited by the sensitivities of the British authorities in its contacts with Nigerians as well as its activities relating to US aid availabilities." ${ }^{428}$ There were chiefly two sources of Anglo-American friction in Nigeria. Belmonte writes that, "Americans found colonial officials too complacent on Washington's primary concern in Africa; UK officers, in turn, thought the US communist mania disproportionate." ${ }^{\prime 29}$ The second source of friction was the bias against US education. The British in Nigeria did not recognize American degrees.

\footnotetext{
427 SH Evans, Head of Information Department, to RHK Marett, 31 May, 1955, TNA CO 1027/83, in Belmonte, "Reining in Revolution," 278.

428 Memo. For Files. Mr. Butler's Comments on his trip through Africa, 15 November, 1957, RG 59, 250/49/15/2, Box 10, NAII, in Belmonte, “Reining in Revolution,” 276.

429 Belmonte, "Reining in Revolution," 281-282.
} 
The Nigerian politicians on the other hand were aggrieved that Washington was directing its foreign aid to countries which displayed more receptivity to communism. The complexity of the relationship is best summarized by Belmonte thus: "For although Americans emphasized communism they did not detect a sufficient threat to warrant US aid. Attendant on Washington's belief that Nigeria should remain in the UK orbit, moreover, was the notion that London should retain development responsibility. Yet while London shunned substantial US engagement in Africa, the UK anticipated generous US development assistance." 430

While these US and British concerns impacted development planning in Nigeria, the biggest challenge facing the independence plans (1955-1962) was the need for capital. As a British dependency, Nigeria received most of its external assistance from Britain. Over half of Nigeria's private foreign investment also came from Britain. For the years 1958-1962, roughly three-fourths of the cost of the development plans was paid for with Nigeria's budget surpluses, a drawdown of its reserves and internal borrowing. The remaining one-fourth of the cost came from external loans and grants. This amounted to $£ 28.4$ million. Britain provided $£ 17.7$ million of which $£ 2.7$ million was a grant and the rest a loan. The IBRD also provided a loan of $£ 10$ million. Nigeria still had a financing gap, which was equal to the external financing that was already arranged. ${ }^{431}$ As shown earlier in this chapter, the US believed that Britain was responsible for development policy in Nigeria and

\footnotetext{
430 Belmonte, "Reining in Revolution," 283.

431 American Consulate general to US Secretary of State, 25 June, 1960, National Archives at College Park, (Hereafter, NA II): 745H. 5-MSP/6-2560.
} 
Washington was reluctant to provide development aid to Nigeria. The US consulate in Nigeria made the argument that it was in the United States' interest that Nigeria be able to fill its funding gap. If Nigeria could not fill this financing gap, it would be disappointed in its attempt "to advance the pursuit of her aspirations for economic and social development by cooperative association with the U.S." 432

Nigeria would need to respond to this gap in two ways: either by seeking assistance from the communist bloc or allowing itself to undergo slow internal development. Neither of the two options were of much benefit to U.S. interests. Therefore, the consulate argued, "Either would tend to interfere with the major U.S. interest in having a successful demonstration in Nigeria of economic and social progress under the type of free political and economic institutions that the U.S. would like to see as widely and firmly established as possible in Africa and elsewhere. Nigeria may be the best prospect in Tropical Africa for such a demonstration." ${ }^{\prime 33}$ Nigeria was of particular strategic interest to the US during this period of the Cold War because it was the most populous African nation. The US was very uncomfortable with Nigeria associating itself with the communist bloc nations. The US consulate in Nigeria was obsessed with the activities of Nigerian elites or politicians who traveled to the Soviet bloc. Their political speeches and writings were closely monitored for any communist influence. It was important to the US that Nigeria did not seek for any form of financing from the Soviet bloc so that her economic development would not be tainted by communist philosophy. Given the

432 Ibid.

433 Ibid. 
size of Nigeria and its potential impact on the African economy, the potential for Nigeria's influence in the region, leading other regional countries toward communism was great. Economically, this also meant that Nigeria would align itself with the Soviet bloc market. Security and stability was also a strategic interest to the United States. Nigeria in the 1950s and 1960s was not only a world exporter of agricultural products but it had also just started commercial oil exploration and production and many US businesses and companies were operating in Nigeria. Oil was discovered by Shell-British Petroleum in 1956. By the 1960s, Mobil One, an American company was carrying out oil exploration in Nigeria. Nigeria by the 1960s had become "an important purchaser of industrial materials, machinery, and transport equipment, rather than consumer goods as in the past.... American entrepreneurs took an important share in developing its oil resources." ${ }^{434}$ Helping to protect this fledging oil industry through development of the country was economically beneficial to the United States. US companies could continue to do business in Nigeria and in turn, a modernizing Nigeria will purchase equipment from the US to help it with modernization.

The US consulate was thus looking for a way in which America's interest in Nigeria would be safeguarded without the United States putting too much money into Nigeria's development against its stated policy. The problem was that of using US aid to finance budget deficits or balance of payment gaps, a problem Nigeria needed financing for. This was difficult because any external capital that was made

\footnotetext{
434 Peter Duignan \& L. H. Gann, The United States and Africa: A History (Cambridge: Cambridge University Press, 1984), 308-309.
} 
available to Nigeria would benefit the Nigerian government and the balance of payments. The US was trying to avoid a problem where Nigeria or any nations that were a beneficiary of US aid were permanently dependent on the United States to pay their debts due to their inability to properly manage their economies. The recommendation of the consulate was that in order to protect US interests, "A number of loans from the DLF and/or Export-Import Bank, plus some modest Special Assistance..." should suffice. ${ }^{435}$

The US consulate's goal of finding a solution to the aid problem was motivated by the frustration that Nigerian leaders felt with the United States' reluctance to provide development aid to Nigeria. The response of Nigerian leaders was the use of a strategy Abou Bamba describes as, "triangulating modernization." ${ }^{36}$ For months in 1960, there was an impasse in Nigeria over development loans. The Nigerian government was unable to receive the loans for which they applied through the DLF and the Export-Import Bank. These two institutions insisted that they could only finance items that were imported from the US. In his budget speech before the Federal House of Representatives on $4^{\text {th }}$ of April

\footnotetext{
435 American Consulate general to US Secretary of State, 25 June, 1960, National Archives at College Park, (Hereafter, NA II): 745H. 5-MSP/6-2560.

${ }^{436} \mathrm{He}$ uses the concept of triangulation to make sense of the presence of America in the Kossou Project in central Ivory Coast. In the planning of this project, this former French colony did not rely solely on France because France was reluctant to provide the money needed for the project, but they sought help from the World Bank and the US which did not only provide technical partners but also loans through the Export-Import Bank. A US company, Kaiser engineers, outbid the French engineering company, which bided for the project. This left bitterness in the French who thought the Ivorian leaders were showing favoritism toward the Americans. France, wanting not to remain in the sidelines watching America encroaching into their sphere of influence, stepped back in when the project needed more funds to run the original operations. See Abou B. Bamba, "Triangulating a Modernization Experiment: The United States, France and the Making of the Kossou Project in Central Ivory Coast," Journal of Modern European History 8, 1 (April 2010).
} 
1960, the Federal Minister of Finance went after the US over its change of policy as regards development loans for Nigeria. The minister said that western nations provided financing only for short-term and not long-term and they were reluctant to provide financing for local goods and services. He noted that any financial assistance that was available was not for a government like Nigeria but for the industrialists because it was only the "industrialist who will wish to purchase substantial quantities of machinery which will pay off loan charges in a fairly short period."437 He continued that in this respect, "Her Majesty's Government in the United Kingdom does take a more enlightened and liberal view of these matters." This was evidenced in Britain providing $£ 3$ million, which could be used as they wished either on imports or local goods and services. He then went on to excoriate the US for the change of policy tying loans to US imports. That created a difficulty for Nigeria accepting the loans because, more often, they could get the goods cheaper in other markets outside of the US. The minister then went on to make his strongest rebuke in the speech against the US. He said, "It is also quite illogical for countries which express a belief in the wisdom of multilateral systems of trade and payments to tie capital exports in a way that is a complete negation of a declared multilateral policy. We in Nigeria, I believe, have shown by our actions that we are prepared to pursue liberal multilateral policies in international trade. We look to other countries for them to reciprocate." ${ }^{438}$ The Minister was triangulating. Nigeria was not going to pledge its allegiance to only one country when it came to finding foreign aid. Though

${ }^{437}$ American Consulate, Lagos to Department of State, Washington, 19 April, 1960, NA II: 745H. 5MSP/4-1960.

438 Ibid. 
Britain remained very generous and it was counting on the United States for aid, if the US was not willing to provide aid, it was going to look to other countries for aid.

\section{The Role of the US Foundations}

While Nigerian leaders were negotiating development aid with the United States government in this time period, there was also a strong presence of American foundations such as the Carnegie and Ford foundations. In his excellent monograph on the influence of the Carnegie, Ford and Rockefeller foundations on American foreign policy, Edward H. Berman argues that the programs that were carried out by these foundations overseas complemented, to a large extent, US foreign-policy initiatives. In fact, these foundations were being subsidized by the US government through the tax-free status that they enjoyed. ${ }^{439}$ Berman identifies four interrelated factors that led to these foundations influence on foreign policy: their possession of significant capital, their ability to allocate this capital to institutions such as universities and authors who in turn (not always) produce works that reflect the foundations worldview, their close association with the decision making apparatus of the capitalist state and finally, their shared view that "the development of the domestic polity and polities abroad can best be advanced through the aegis of the world capitalist system, dominated by the United States." ${ }^{440}$ Berman acknowledges that there were occasional differences between the foundations and the US

${ }^{439}$ Edward H. Berman, The Influence of the Carnegie, Ford, and Rockefeller Foundations on American Foreign Policy: The Ideology of Philanthropy (New York: State University of new York Press, 1984), 39.

${ }^{440}$ Ibid., 38. 
representatives abroad but these differences were insignificant compared to their shared interests which was to protect US interest and the world capitalist system. He writes, "This shared belief in the general direction of United States foreign policy after World War II - always allowing for minor differences - resulted from, among other things, the fact that many of the same individuals were so directly involved in the political fortunes of the state, the nation's major corporate and financial institutions, and the foundations." ${ }^{441}$

Carnegie's major involvement in Nigeria, for instance, was in the field of education. The view of Carnegie was that education was the key to development. Thus, Carnegie's efforts "as well as of those they mobilized, such as Ford and various U.S. agencies, were directed to developing a system of colleges and universities that would mass produce men and women qualified to 'develop' Africa." 442 The plan that these foundations had for Nigeria involved intervening in Nigerian education.

One such school that would receive the focus of the foundations was the University of Ibadan, the oldest Nigerian university founded in 1948 as an independent external college of the University of London. Through the instrumentality of its first Nigerian Vice Chancellor, Kenneth 0. Dike, himself formerly a professor at Northwestern University, the university received massive US funding from the foundations to help it expand. The University of Ibadan became not only the "intellectual engine" of the nation but a place "increasingly oriented to

\footnotetext{
441 Ibid., 39.

442 Inderjeet Parmar, Foundations of the American Century: The Ford, Carnegie, \& Rockefeller Foundations in the Rise of American Power (New York: Columbia University Press, 2012), 170.
} 
serving development and nation building in independent Nigeria." ${ }^{433}$ Between 1958 and 1973, the University of Ibadan received a total of $\$ 9$ million from the Rockefeller Foundation and $\$ 4.5$ million from the Ford Foundation. As Inderjeet Parmar argues, these grants were awarded to Ibadan without consultation with the Nigerian government, and the foundations failed to take into consideration the strong regional political arrangements in Nigeria. ${ }^{444}$

If the foundations thought that by creating a strong Nigerian University and using it as an engine to drive national planning and development, they were catering to the development needs of Nigeria as a whole, they were making a political and cultural mistake. The then political arrangement in Nigeria encouraged emphasis on regional development, which meant that funding the University of Ibadan was not funding Nigeria but funding the Western Region. The different political regions also represented semi-cultural blocks. The Western region was comprised mostly of the Yorubas, the Eastern Region was comprised mostly of the Igbos, and the Northern region was comprised mostly of the Hausa/Fulanis. Within these different regions were minority groups. But on the whole, the three regional governments represented three large ethnic groups that comprised the Nigerian polity. ${ }^{445}$ It was a mistake for the foundations to think that by building up the University of Ibadan, an Igbo or an Hausa would sincerely thank them for their generosity to Nigeria. Though

\footnotetext{
443 Ibid. ,170-71.

444 Ibid., 172.

445 On ethnic and regional politics in Nigeria, see Ebenezer O Aka, "Regional Inequalities in the Process of Nigeria's Development: Socio-Political and Administrative Perspective," Journal of Social Development in Africa 10, 2 (1995): 61-80; Michael Crowder, The Story of Nigeria (London: Faber \& Faber, 1973).
} 
the foundations had a plan for Nigeria, their plan was one created by outsiders who did not adequately understand the ethno-political differences that made up the Nigerian polity. The other ethnic groups did not see the University of Ibadan as their university. It was a university for western Nigeria. It was such responses that later led to the creation of the University of Nigeria, Nsukka (located in the eastern region) and Ahmadu Bello University, Zaria (located in the northern region).

\section{The Foundations, Arnold Rivkin and the African Project}

Beyond the work that the foundations did in Nigeria, the Carnegie foundation and later the Ford foundation were the sponsors of the African project at CIS founded and headed by Arnold Rivkin. There was no American social scientist who propagated the gospel of modernization in Nigeria in the late 1950's more than Arnold Rivkin. Rivkin was born in New York and he studied economics at Brooklyn College. He later got a law degree from Harvard Law School. In 1950, he worked as the Assistant General Counsel of the European Headquarters of the Marshall Plan in Paris. During his time in Paris, he had the task of coordinating US economic aid. It was during this time that he made his first trip to Africa. He visited Madagascar. ${ }^{446}$ This was the beginning of his involvement with Africa. The US institute for which he worked for was the International Cooperation Administration, (ICA). ${ }^{447}$ This institution was the precursor to the United States Agency for International Development. ICA had been present in Nigeria from the middle of the 1950s and

446 Grubbs, Secular Missionaries, 47.

447 Grubbs, “Bringing 'The Gospel of Modernization' to Nigeria,” 284. 
helped in administering the Development Loan Fund (DLF). The DLF was created in 1957 under Eisenhower's administration as the first US foreign aid program that was explicitly focused on development goals. ${ }^{448}$

In 1957, Rivkin joined CIS and there he founded the African Economic and Political Development Project. It was Rivkin who pushed the direction of the Center beyond Asia to Africa. Rivkin believed that a study of Africa was necessary because of the political changes that were taking place on the continent. Most African nations were at this time at the verge of independence. In West Africa, Ghana gained her independence in 1958 and many others would follow in 1960. While political changes were swiftly taking place, the economic changes were not keeping pace. In July of 1958, CIS submitted a grant application to the Carnegie Corporation to help fund the African project. A careful look at this proposal is important because it reflected Rivkin's ideology as it relates to emerging African societies. ${ }^{449}$

Rivkin believed that what happened in Africa would have an impact on the world and that the world needed to pay close attention to what was going on in Africa. He wrote in the application, "The focus of the Project will be on Africa as a factor of growing importance in world politics and economics. This means that a primary concern of the Project will be the interrelationships of Africa and the free world, and the interplay of selective developments within each of the two areas on

\footnotetext{
448 Blackmer, The MIT Center for International studies, 104.

449 Though the grant application was not signed by Rivkin but by the director of the center, there is no doubt that Rivkin wrote the grant and it reflected his thinking. At the time, CIS did not have any African specialist nor was it carrying out any research on Africa except the one Rivkin started the previous year. In discussing the document, I will refer to it as Rivkin's work.
} 
one another. It will also inevitably mean the study and analysis of internal developments in Africa as a prerequisite to understanding their significance and assessing their impact on the free world." ${ }^{450}$ Rivkin called for an in-depth study to be made of four African territories: Nigeria, French West Africa, the Belgian Congo, and the Federation of Rhodesia and Nyasaland. He wanted the project to examine diverse areas to enable it to make generalizations about the whole continent south of the Sahara. He argued that the four areas selected "illustrate the great range of difference in metropole policies and programs and the differing impact of these policies and programs." ${ }^{451}$ His selection showed that diversity: a British colony in West Africa, Nigeria; then the French colonies in West Africa; a Belgian territory; and then a British territory in southern Africa that had European settlers.

A key question is: why did Rivkin select Nigeria? He believed that on achievement of independence in 1960, Nigeria would be one of the most important independent countries in Africa. Nigeria would play a vital role in West Africa with respect to its relationship with Ghana, the French Cameroons and Francophone West Africa. ${ }^{452}$ What Rivkin wanted to study were the problems of economic development and how these interfaced with political change. He also believed that it was important to study these territories because with the emergence of independence, the economic relationships that existed between them and Europe

\footnotetext{
450 Politics of Transition Proposals, African Projects, Proposal for a Project on Economic Development and Political Change in Africa South of the Sahara, July 1958, MIT Institute Archives and Special Collections (Hereafter MIASC): AC 236.

451 Ibid.

452 Ibid.
} 
would likely be affected. A particular interest of the study was the US. Rivkin wrote, "The interests of the United States will be given particular attention both from the point of view of direct United States interests and from the point of view of the triangular relationships among the United States, Africa and Western Europe."453 This idea of triangular relationships reflected the approach to development in the late colonial and early "postcolonial" period. No longer were relations bilateral, metropole to colony, but the United States, as well as other international organizations such as IBRD had competing interests. ${ }^{454}$

Rivkin's study was to be carried out by an interdisciplinary research teams: economists, sociologists and political scientists, and after their initial preliminary research in Cambridge, they were going to spend some time doing fieldwork in these African territories. While the director of the center, Max Millikan, was to be in charge of the research, it was Arnold Rivkin who was to direct the research. It is important to note that Rivkin's expertise was neither in sociology, African economies or political science. He was a lawyer by training. His expertise on Africa was based on the years he worked in the African operations of the International Cooperation Administration and his many visits to Africa. In its preliminary research, the center also collaborated with the United Nations' Bureau of Economic Affairs' African Unit. The center also brought in more senior researchers to work on the African project. The estimated cost of the research was $\$ 250,000$ and it was to cover the period from 1 October, 1958 to 30 June, 1961. The grant application was

453 Ibid.

454 See Bamba, "Triangulating a Modernization Experiment.” 
submitted to the Carnegie Corporation on 2 October, $1958 .{ }^{455}$ In November of 1958 , Carnegie approved a grant of $\$ 200,000$ to CIS for its research on Sub-Saharan Africa. ${ }^{456}$

Having secured the grant for the African Project, CIS brought in three individuals that were instrumental to the center's research on Nigeria: Wolfgang Stolper, Charles Nixon and Archibald Callaway. Stolper was born in Vienna, Austria in 1912 and he migrated with his family to the US in 1933. He studied under Joseph Schumpeter at Harvard and graduated in 1938 with a doctorate in Economics. From 1941, he was professor of Economics at the University of Michigan Ann Arbor. He took a leave of absence from the University of Michigan for the academic year 1958/59 to write a book on East German economies. He spent this year at CIS working on the book. It was during this time at CIS that he became curious about Europe's African colonies and he became interested in African economies. Stolper will later spend time in Nigeria working on the Nigerian development plan.

Charles Nixon, on the other hand, was a political scientist. He was born in Rochester, New York. He earned his doctorate in political theory and philosophy from Cornell University in 1944. Between 1944 and 1947, he taught at Smith College, Northampton, Massachusetts. In 1947, he joined the faculty at the University of California, Los Angeles as a political science professor. In 1955, he received a one year grant from the Carnegie Corporation to teach at the University

\footnotetext{
455 J. P. Donahue to Carnegie Corporation of New York, 2 October, 1958, MIASC: AC 236.

${ }^{456}$ Carnegie to J. A. Stratton, 21 November, 1958, MIASC: AC 236.
} 
of Natal, Durban, South Africa. When he returned in 1956, his interest in Africa was heightened. In 1959, he was hired by CIS to carry out a research for the African Project in Nigeria. Between 1959 and 1960, he carried out several research trips to Nigeria, Rhodesia and Nyasaland. Archibald Callaway was an economist that joined the African project at MIT to carry out research in Nigeria.

While Arnold Rivkin himself did not move to Africa to carry out research there, he made frequent visits from his base in London and directed research from there. His two researchers in Nigeria were Nixon and Callaway. Nixon's research focused on the political factors that influenced economic decision making in Nigeria. His analysis centered "on the general problem of evolving a political system which can effectively set and execute policy concerning the state's economic functions." 457 After spending time in Nigeria, he went to the Federation of Rhodesia and Nysaland to continue his research.

Archibald Callaway spent a considerable amount of time in Nigeria. Even after the original grant expired in 1961, he remained in Nigeria to continue his research with the help of a supplemental grant from the Ford Foundation. Callaway's research focused on the problem of surplus labor. He completed his research in 1965. The labor in question was young people in Nigeria who had finished their primary education and were unable to find jobs. Callaway's research was necessitated by the presence of young people roaming the streets who had

\footnotetext{
457 Politics of Transition: Proposal, 1960, Proposal for a Program of Education and Research on the Politics of Transitional Societies, MIASC: AC 236.
} 
completed primary education but did not have the financial resources to go to secondary schools and there were no jobs available to them. In his thinking, this was not only a social and economic threat to Nigeria but it also constituted a political threat. The fear was that unemployment, especially of young people, would lead to discontent and frustration, which could lead to revolution or communist influence. What he did in his research was to follow the lives of some of these young people from their villages through primary education and their quest for jobs or higher education. His solution to the problem of school leavers in Nigeria was the creation of "modern agricultural experimental farms that will provide challenging employment for school-leavers who would otherwise swell the grown mass of urban unemployed." 458

This "school leaver" problem was not new in the 1950s. Experts in the Colonial Office had identified it as early as the 1930s and 40s. As noted by Hodge, "The old problem of labor shortage was transformed by the Depression into a new crisis of labor surplus, in the form of growing unemployment and underemployment, low wages, and widespread urban and rural immiserization." ${ }^{459}$ Callway's thinking was in no way a break from colonial thinking. Even the solution he proffered for this problem was one that was already advanced by the colonial developers in the 1930s and 1940s when they advocated a return to the land, an agrarian bias. It was for this reason that colonial officials began to advance more

\footnotetext{
458 Final Report to the Ford Foundation on Research on Government Policies Toward Surplus Labor Resources in West Africa, 1962-1965, 6 April, 1966, MIASC: AC236.

${ }^{459}$ Hodge, Triumph of the Expert, 18.
} 
extensive state-directed and social engineering development initiatives in the 1940s. The fear was that without such interventions, the problem of surplus labor might lead to a breakdown in colonial order. ${ }^{460}$

\section{The Gatekeeper State}

In his book, Africa Since 1940, Frederick Cooper notes that colonial states were gatekeeper states. He argues that these states "had weak instruments for entering into the social and cultural realm over which they presided, but they stood astride the intersection of the colonial territory and the outside world. Their main source of revenue was duties on goods that entered and left its ports; they could decide who could leave for education and what kinds of educational institutions could come in...." 461 During colonial rule in Nigeria, many of the subjects had a ceiling on the level of education that they received. The education that many of the people received was primary education. A very small few acquired secondary education. Those with university degrees were scarce. Up until the dawn of independence, Nigeria had only one university, the University of Ibadan, and it did not offer advanced degrees. Most Nigerians who were privileged enough to receive college degrees and sought for advanced studies had to look toward the United Kingdom or America. Thus, most of the nationalist elites held American and UK degrees. As stated earlier in this chapter, there was bias against American degrees. The control exerted by the colonial state as a gatekeeper limited the opportunities

\footnotetext{
460 Ibid.

${ }^{461}$ Cooper, Africa Since 1940, 5.
} 
that were available to Africans to exercise leadership and prove their capabilities. The widespread availability of such opportunities could have potentially defeated the colonial ideology that colonial peoples were incapable of governing themselves. Thus, in the late 1950s when these African countries started marching rapidly toward independence, there was a major problem of effective human power. What the new African leaders inherited were the keys to the economic gates without the means of using these economic resources to better the lives of their citizenry. The rhetoric of nationalism had convinced the people that colonial rule was a great evil and that independence was going to afford African nations the same level of prosperity as enjoyed by the Europeans and other Western countries. What the rhetoric did not emphasize was that African leaders, due to decades of colonial rule, had not the financial and human resources to transform their people within a short period of time. There were rising expectations and aspirations of the future, what James Ferguson calls the "expectation of modernity." ${ }^{62}$ Failure to provide the dividends of self-rule within a short time was only going to lead to the people turning against their own African leaders. This explains the reasons for most of the internal conflicts and strife that many African nations experienced shortly after independence. To borrow Frederic Cooper's conception, African leaders inherited the mantle of a gatekeeper state without the mechanism of subjecting the people to the new rule. 463

462 See, James Ferguson, Expectations of Modernity: Myths and Meanings of Urban Life on the Zambian Copperbelt (Berkeley: University of California Press, 1999).

${ }^{463}$ Cooper, Africa Since 1940, 141. 


\section{Wolfgang Stolper and the Nigerian National Development Plan}

In any development planning for a newly independent country like Nigeria, moreover, questions of unemployment and lack of basic skilled manpower were not the only issues that confronted planners. There was also the problem of finding suitable high-level technocrats to manage Nigeria's economy and varied governments. Though most British officials and experts remained in the country, Nigeria officials reached out to technocrats from the United States to help. As Nigeria began plans to prepare a post-independent development plan, it turned to the local Ford Foundation office to help it recruit Western economists to assist in putting together the plan. The Ford Foundation Office in New York contacted a Harvard economics professor, David Bell, who "had helped organize and provide Harvard advisory assistance, funded by Ford, to the planning commission in Pakistan. Bell learned of Stolper's interest and enlisted him to head the Nigerian team." ${ }^{464}$ Other team members included Lyle Hansen, a Harvard economist who had worked in Pakistan, and Peter Clark who had just completed his PhD in Economics from the Massachusetts Institute of Technology. None of these three economists were experts on Nigeria or African colonial economies for that matter. Stolper's area of research was on East German economy. His first experience with Africa was an eight weeks visit to Nigeria organized by CIS in which he collected data on Nigeria and talked with some of the officials who worked there.

\footnotetext{
${ }^{464}$ Clive S. Gray (ed.), Inside Independent Nigeria: Diaries of Wolfgang Stolper, 1960-1962 (Burlington, VT: Ashgate Publishing Company, 2003), ix.
} 
Stolper's very candid diary, which he wrote during these eight weeks visit and his subsequent 16 months residence in the country tells of his interactions in the newly independent country and how he fashioned the Nigerian National Development Plan. His ignorance of Nigeria and the impact of British colonial rule is revealing as he wrote during his first few days of arriving in Nigeria in July of 1960: “The Britishers here have no racial prejudices whatsoever. Clubs, residential areas, everything is desegregated." 465 Though one may argue that he was contrasting this experience with the US experience, it was such a broad generalization. It is naive to think that because there was no segregation, there wasn't racial prejudices. The crowd that Stolper hung out with, something he did a lot during his stay in Nigeria, were mainly African elites with degrees from the US and Europe. ${ }^{466}$ Later in the diary, he would mention one racial act he saw committed against an African. He recorded: "While shopping in Kingsway, the local department store run by United Africa Company, I had my first taste of racism; a minor one at that. A middle-aged English woman yelled at a uniformed African doorman, 'Don't you touch me, you touched me,' and when he tried to point out that he hadn't deliberately, she just yelled 'Shut up."'467 If this was the first incident of racial prejudice he saw, he was either blinded by his own racial prejudices or was just naïve. His own diary tells a different story. Before this time, Nigerians were spoken of disparagingly by the Europeans working there. The incident at Kingsway took place in August but on the

\footnotetext{
465 Ibid., 2.

${ }^{466}$ His diary is peppered with parties and receptions and outings almost on a daily basis and one wonders how much time he actually committed to work. Yet, again and again, he speaks of working really hard.

${ }^{467}$ Gray, ed., Diaries of Wolfgang Stolper, 48.
} 
$28^{\text {th }}$ of July, he recorded a conversation that he had with a Scottish medical statistician. The latter told him that in "Nigeria you could find everything from the most sophisticated Westernized African, such as his successor, to cannibals on the Cameroon border, where census takers take the risk of being eaten, and officials are allowed in only with armed guards to prevent them from being killed with poisoned arrows." ${ }^{468}$ That Stolper did not see any racial prejudices in this statement leaves much to the imagination. His statement spoke to the implicit assumption about the stages of development that most Westerners held that time. The assumption was that Africans who were westernized were sophisticated and the non-westernized Africans were cannibals who feasted on human flesh for protein.

In any case, Stolper was excited about the job he was going to do in Nigeria. He saw his assignment as a unique opportunity to shape the events of history in the most populous African nation. He wrote: "I have the most enviable assignment a man can have: developing an integrated plan for the most important African economy with the biggest and most hopeful future of any African nation....There are strong autonomous, almost (but not quite) separatist tendencies in Nigeria, and I have a chance to help weld the territory into a nation. Even hardships are worth this opportunity." ${ }^{469} \mathrm{He}$ saw himself as having the task of achieving what the British could not achieve since the British Governor Lord Lugard amalgamated the Northern and Southern protectorates of the country on the $1^{\text {st }}$ of January 1914. Stolper naively believed that he could singlehandedly do this. In this sense, he

469 Ibid., 19. 
envisioned himself as the Nigerian messiah who through his gospel of modernization and economic planning, would help create a new Nigeria that would be better integrated and grow economically. In a sense, this vision conflicted with what he said out loud. In a discussion with the permanent secretary of the Ministry of Economic Development (MED), Charles Thompson, one of the senior British civil servants, Stolper assured him that he (Stolper) was a "Nigerian civil servant with a specified job to do in a specified time, taking general instructions from my superiors, rather than an academic who would do a research job as he pleased in his own good time." 470 Absent in this statement was his messianic vision to remake Nigeria. His statement that he was a Nigerian civil servant taking orders from his superiors was in response to the information given to him by Thompson that the prime minister (PM) would be getting an economic adviser from the World Bank. He wanted to make sure that there wouldn't be conflicts between the two of them. Though Stolper did not think there would be any rivalry, it became a normal occurrence between him and Narayan Prasad ${ }^{471}$, the economic adviser to the PM.

\section{Crafting the Nigerian Plan: The Stolper -Prasad Conflicts}

Throughout the crafting of the Nigerian plan, Stolper and Prasad were in constant disagreements with each other and this fractious relationship no doubt affected the final Nigerian plan. They wrestled publicly over who was responsible

\footnotetext{
470 Ibid., 5.

471 Narayan Prasad was an Indian Economist with the World Bank. He was assigned to Nigeria as an economic advisor to the prime minister. On this capacity, he was a member of the JPC and he worked closely with Stolper in the designing of the Nigerian plan.
} 
for the Nigerian National Plan (NNP). Stopler felt Prasad was reneging on the agreement they had in "Washington not to have public differences" until they had them ironed out in private. ${ }^{472}$

Stolper and Prasad's first conflict seemed to have started on the $27^{\text {th }}$ of February 1961 during a strategy meeting for the Joint Planning Committee meeting (JPC). ${ }^{473}$ There were differences between them on planning targets. Stolper wrote: "He wants us to make a sort of bargaining plan, which we don't want to do. He claimed that in India the economists made projections regardless of the foreign exchange gap, and the necessary foreign exchange was forthcoming. But this was not really true during India's second Five-Year Plan." 474 Stolper wrote furtherthat that Prasad was trying to make himself responsible for the plan, something Stolper disagreed with. He believed that he had to assert himself and suspected there would be problems between the two of them. ${ }^{475}$ The disagreement between Stolper and Prasad was not a radical difference on how to approach development, as we would see later in the chapter, it was a question of who was going to control the process. Stolper wanted to devise a strategy with his colleagues, Hansen and Clark on how to work with Prasad. He believed that people were getting confused by all the advisors. He claimed he had no objections if "Prasad wants to be the big shot", however, he wanted to keep the identity of their operations separate and clearly fixed. The

472 Gray, ed., Diaries of Wolfgang Stolper, 95.

473 The JPC was the joint meeting between the regional and federal officials responsible for planning.

${ }^{474}$ Gray, ed., Diaries of Wolfgang Stolper,69.

475 Ibid. 
reason was because he thought it was "a bad idea to be too closely identified with either Prasad's successes or his failures."476

From these initial conflicts, there was already a crack in the team that was supposed to put together the plan. Their disagreements were getting in the way with putting the plan together. Prasad had direct access to the PM while Stolper's own influence was with the Federal Minister of Economic Development, Wachuku Jaja, who, according to Stolper's diary, did not have that much interest in their work as he was jostling to be made the Minister of Foreign Affairs. ${ }^{477}$ Prasad used his access to the PM to undercut both those in economic planning and in finance. The permanent secretary of finance, Reginald Clark, a British colonial official, in March of 1961 wanted a meeting with Stolper and Hansen to discuss one of Prasad's memos to the PM. He was disturbed by "Prasad constantly writing memos to the PM and others, without sufficient factual information." ${ }^{478}$ Stolper would acknowledge that Prasad was not always wrong. In fact, he thought of him as a fine and able economist. Prasad asked for a meeting with Stolper in order for them to work out their relationship. They had a meeting and Stolper's conclusions were that Prasad was irritating not only to the British but also to the Nigerians. Prasad wanted to change the organizational setup immediately. Stolper felt that in the long run, Prasad was probably right but if they got embroiled in that now, they would never

\footnotetext{
476 Ibid., 71.

477 Ibid.

478 Ibid., 79.
} 
produce a plan. ${ }^{479}$ While there were few differences between Stolper and Prasad such as Prasad's focus on list of investment projects rather than a macroeconomic framework, a position favored by Stolper, in the diary, Stolper acknowledged that their approaches came to "pretty much the same thing." 480 What was at issue was the way that Prasad did things. The impression one gets from Stolper's diary is that Prasad wanted to call the shots and always wanted it his way.

Throughout the development of the plan, the conflicts between Stolper's team and Prasad only escalated. In April of 1961, for example, Hansen informed Stolper that Prasad had given the US ambassador, Joseph Palmar, much higher figures for aid needs than the ones they had come up with, yet he was unwilling or unable to tell him how he arrived at the figures. Stolper condemned Prasad's recklessness and believed that it would eventually blow up in his [Prasad's] face and might spill over to affect his own team. Stolper wrote thus about Prasad: "His recklessness in giving advice may give the whole economic advising business a bad name. Moreover, we have reason to believe that he says one can't really plan in Nigeria because there are no statistics. Of course statistics are rudimentary to say the least. But the point illustrates the difference in approach between him and us. He really is a planner which we are not. He would consider exchange control quite lightly while we would consider it a very serious step to be avoided if at all possible." 481 One of the issues here was the figures that they were using. Stolper, it

\footnotetext{
479 Ibid., 80.

480 Ibid., 69.

${ }^{481}$ Gray, ed., Diaries of Wolfgang Stolper, 93.
} 
seems, was caught up in the statistical data that had been drawn and published in 1959 by the National Economic Council. Prasad was suspect of this data and did most of his projections without sharing how he arrived at the numbers while Stolper used those numbers for his projections. ${ }^{482}$

Prasad's actions motivated Stolper to begin questioning his motives. He concluded that Prasad, being Indian, was anti-English as well as patronizing to Nigerians. Stolper believed that Prasad was unhappy and filled with disbelief that Nigeria's economy was growing faster than that of India's, despite the fact that the Indians were trying much harder than the Nigerians. Despite these problems that Stolper had with Prasad, he still had compliments for him. He believed Prasad was a "good, competent man, a most unusual World Bank type...." 483 Only a few days later, Stolper wrote in his diary entry accusing Prasad of a flagrant lie and threatening to resign rather than taking any further orders from Prasad. By the 16 of April 1961, there was a public standup between Stolper and Prasad at Toby Lewis' home. ${ }^{484}$ Prasad told Stolper that he would let them proceed with planning if they wanted, but he did not think they would get anywhere with it. Stolper retorted that Prasad was in no position to let them proceed as they wished. Stolper said he was responsible for planning and Prasad was responsible for short-term advice. Prasad shot back that "no one had told him to stick to short-term advice." Stolper rejoined

482 See, National Economic Council, Economic Survey of Nigeria: 1959 (Lagos: Government Printer, 1959).

483 Ibid.

484 Toby Lewis was a British colonial expert. He was the Second Permanent Secretary at the Federal Ministry of Economic Development during Wolfgang Stolper's time in Nigeria. 
that he understood it to be their respective terms of reference. Prasad rebuffed that he was wrong. In the end, Stolper thought that Prasad might have been correct. ${ }^{485}$

The disagreements between these planners were reminiscent of those in the colonial period. Like the numerous conflicts between Mackie and the political department of the colonial state, there were several other conflicts throughout the duration of the time Stolper and Prasad were working together, which space does not permit me to examine in further detail. However, I believe it is important to present some of these conflicts because they reveal the other side of development planning, which is the human side. You have two main characters, Stolper and Prasad, jostling for power and control to the point where they allowed it to adversely affect their work. The conflicts subsumed the major part of their work and to a great extent these conflicts arose from their different ideologies on development planning. According to Stolper, the main disagreement between them was Prasad's belief that the poor quality of the statistics meant what needed to be done was to string together a series of projects. ${ }^{486}$ Stolper's approach was based on the need to "establish a macroeconomic framework within which the effective demand for investment, and the supply of domestic and foreign finance, can be estimated." ${ }^{487}$ He believed that there was a need for a framework in which all the individual projects and programs could be placed. If there was no such framework, he asked, "How else could one decide which projects to omit in case resources were

\footnotetext{
485 Gray, ed., Diaries of Wolfgang Stolper, 97.

486 Ibid., 95.

487 Ibid., xviii.
} 
not forthcoming? How else could one ensure consistent programs and projects?"488 In other words, Stolper's view was more of a programmatic approach and Prasad's was more of a project-based approach. ${ }^{489}$

\section{The Art of the Possible}

Despite the disputes with Prasad, Stolper was the architect of the Nigerian plan. Shortly after leaving Nigeria, Stopler wrote a book, titled Planning without Facts, in which he discussed his experiences formulating the Nigerian plan. In this book, we see clearly Stopler's approach to development planning. He argued in the book that the central problem of development is how to allocate resources for growth. He wrote: "This mobilization and allocation may involve the creation of institutions and of a political consensus. It involves economic policies and specific action by government and the private sector." 490 In Nigeria's case, there were barely substantial statistics to base their projections on and he himself was largely unfamiliar with the country. He saw the plan as a way of giving sense to the direction of the economy. In formulating this plan, Stolper recognized the limitations that the Nigerian context placed on him. As he stated, the planner must realize that "whatever can be done will be the result of a double compromise

\footnotetext{
488 Ibid., 95.

${ }^{489}$ It is important to note that this is Stolper's perspective on his disagreement with Prasad. My archival research has not yielded any results on Prasad's views. Other recent works that have discussed this plan have also relied on Stolper's diary. See Dibua, Development and Diffusionism; Grubbs, Secular Missionaries; Mary S. Morgan, “On a Mission’ with Mutable Mobiles.” Working Papers on the Nature of Evidence, 34/08, London School of Economics, London, 2008.

http://eprints.lse.ac.uk/22500/1/3408Morgan.pdf.

490 Wolfgang F. Stolper, Planning without Facts: Lessons in Resource Allocation from Nigeria's

Development (Cambridge, Massachusetts: Harvard University Press, 1966), 2.
} 
between conflicting political views and ends and between what is ideally desirable and what is possible." ${ }^{491}$ As in the colonial period, development was negotiated and this was the realization of Stolper. This was a far cry from the bold pronouncements of modernization theory.

In Nigeria, what Stopler dealt with was the conflicts between the regional governments and the federal government. As noted earlier, the federalization of Nigeria in 1954 meant that the different regions had more autonomy in the design of their plans. The three regions of Nigeria were all working on their regional plans and then there was a federal plan. Thus, there were actually four different plans that were being written. Stolper had to navigate the relationship between the regions and the federal government. One case in point was after the plan's white paper ${ }^{492}$ had been drafted. The PM insisted that each regional parliament would debate only its own plan and the plan's white paper would not be taken to any regional parliament. The PM, understanding the local situation, did not want regional plans debated in the federal parliament and vice versa. Despite persuasions by Stolper and his team, the PM refused. He declared that the three regional plans would be printed along with the plan's white paper as the national plan. Stopler was frustrated and disappointed with the PM's decision. He met with Toby Lewis later and expressed his disappointment that the PM had vetoed the debate of the regional plans in the national parliament and also vetoed debating the white paper in the

491 Ibid., 27.

492 The plan's white paper was later published. Federation of Nigeria, Federal Government Development Programme, 1962-68, Sessional Paper No. 1 of 1962 (Lagos: Federal Printing Division, 1962). 
regional parliaments. To Stopler's surprise, Lewis immediately congratulated Stolper. Lewis told him the PM's "concern was to hold the Federation together, and he had to prevent discussion of Regional matters in the Federal Parliament, which would disrupt the national effort. He thought the PM had acted wisely, in statesmanlike fashion." ${ }^{493}$ As it turned out, the PM's action saved the plan. The ethnic rivalries between the three regions would have killed the national plan because of brinkmanship between the representatives of the different regions.

Stolper also had to deal with what was ideally desirable versus what was possible in practice. This also happened to be one of the reasons for the conflicts between him and Prasad. Stolper viewed planning in Nigeria from the onset as a general problem of "resource allocation and mobilization rather than merely the development of capital budgets." ${ }^{494}$ On the other hand Prasad's approach to development was in line with Paul Rosenthein-Rodan's Big Push model in which he believed that large amounts of investments are needed for "backward" countries to move toward economic development. ${ }^{495}$ Prasad told the different regions to think big and that the money would come through foreign aid. The regions then put together gigantic projects that they did not have the financial resources to execute. This was precisely the problem of the Eastern Region. When it became obvious that the resources wouldn't be available, everyone wanted the other's project to be cut. Stolper's approach was that the resources were scarce. He believed that "all uses of

493 Gray, ed., Diaries of Wolfgang Stolper, 251.

494 Stolper, Planning without Facts, 44.

495 Paul Rosenthein-Rodan, "The International Development of Economically Backward Areas," International Affairs (April, 1944). 
resources compete at any one moment of time for all available resources" and that it was a mistake to see development and growth solely in terms of increased capital formation. He also believed that capital expenditures would inevitably build up future recurrent expenditures and that the amount of "resources that can be raised will depend significantly on the rationality of their use." ${ }^{496}$ In planning development, it is very important to look at the recurring budgets. For example, even if you receive a school or a hospital as a gift, there would be a need for domestic resources to keep these running. ${ }^{497}$

In designing the Nigerian plan, Stolper had in mind the rational allocation of resources. In his instructions to the staff of the Economic Planning Unit (EPU) in 1961, he wrote, "The Plan will consist of: a Capital Budget; a Recurrent Budget; and Policy Recommendations. This is necessary in order to ensure that the resources available to Nigeria are used in a reasonable manner. For present purposes, I have asked that all Ministry programs for the next five years to be collected: we must know their total capital programs as well as the expenditures which will be generated by the new programs and the expected recurrent expenditure for continuing programs." ${ }^{498}$ Due to political considerations, the Nigerian plan was bigger than the resources that were available to execute it. While Stolper's view was that the plan should be scaled down, the government, for political reasons, did not cut it but instead extended the implementation of the plan from five to six years. As

\footnotetext{
496 Stolper, Planning without Facts, 44-45.

497 Ibid., 46.

498 Ibid., 46-47.
} 
Stolper himself concluded, "it is a mistake to expect any real plan to be wholly rational in economic terms or to be wholly consistent. The economist may regret that this is so, and the politician may come to regret some of his decisions when they have begun to backfire, when they fail to achieve his political ends, and when they raise new and yet more disagreeable problems. But it is futile to discuss a real plan as if it were an academic exercise, for a real plan is inevitably a compromise." ${ }^{499}$ So was the fate of the Nigerian plan.

\section{The Nigerian National Development Plan}

It would be a daunting task to attempt to analyze in details the four plans that made up the Nigerian National Development Plan, 1962-68. The plan's published version presents an important summary in pages 23 to 24 . The target of the plan was to achieve a growth rate of 4 per cent per year and to raise this if necessary. The goal was to achieve this growth rate by investing 15 per cent of GDP and raising per capita consumption by about 1 per cent per year. The plan also had as a goal to raise the domestic saving ratio of 9.5 per cent of GDP in 1960 to about 15 per cent or higher by 1975 . This, it was believed, would lead to self-sustaining growth. The plan also had as a goal to develop as rapidly as possible "opportunities in education, health and employment; and to improve access for all citizens to these opportunities." 500

\footnotetext{
499 Ibid., 50.

${ }^{500}$ Federation of Nigeria, National Development Plan, 1962-68 (Lagos: Federal Ministry of Economic Development, 1962), 23.
} 
The plan summary then went on to outline specifically the things that needed to happen in order to "achieve a modernized economy consistent with the democratic, political, and social aspirations of the people." 501 The goals outlined and the specific projects associated with them were not much different from those carried out during colonial development. In fact, only the first two listed showed some divergence from colonial development. Here, they are as summarized:

- the creation of more jobs and opportunities in non-agricultural occupations;

- the provision of advisory and training services to Nigerian businessmen to enable them to compete more effectively at home and abroad;

- the increase in the production of export crops through better seed distribution and more modern methods of cultivation, as well as through the increase in the area under cultivation;

- the introduction of more modern agricultural methods through farm settlements, cooperative (nucleus) plantations, improved farm implements such as hydraulic hand presses for the expression[sic, extraction] of palm oil, and a greatly expanded agricultural extension service;

- the expansion of the installed capacity of electricity generation to $643 \mathrm{MW}$ by 1968 ;

- the expansion of railway mileage by the remaining 293 miles of the Bornu Extension; and an additional 14 Diesel Engines and 1485 wagons;

- the provision of 7 new docks in Lagos and Port Harcourt capable of handling an additional 3.6 million tons;

- the expansion of the system of tarred roads by about 3,000 milies; and completion of the new Niger River bridge at Onitsha and the Second Mainland Bridge at Lagos; and

- the expansion of cement capacity to not less than 980,000 tons per year. ${ }^{502}$

Though rhetorically, modernization theorists made bold proclamations about remaking these former colonial holdings that have remained backward as a result of colonial rule, in practice, they repeated most of the same projects that had been

\footnotetext{
501 Ibid.

502 Ibid., 23-24.
} 
carried out as part of colonial development policy. In the case of the Nigerian national plan, there were not many new ideas on the table. In terms of agricultural development, the 1962 plan bore resemblance to the 1945 agricultural plan. It was not uncommon that "postcolonial" planners returned to older colonial files to draw their development ideas from them. In some cases, the same buildings and offices which housed the colonial developers were also the ones that were used by "postcolonial" developers. ${ }^{503}$

\section{Financing the Plan: American Aid}

Despite this resemblance, the 1962 plan, unlike that of 1955-62, would receive a significant amount of financial aid from the US. Two important changes were responsible for this: the Nigerian independence from Britain on October 1, 1960 and President John F. Kennedy's assumption of office as President of the US. The latter, even more so than the former, was chiefly responsible for the US generous assistance to Nigeria. On the occasion of Nigeria's independence, the US was well represented. President Eisenhower wrote to Her Majesty, the Queen of

\footnotetext{
${ }^{503}$ In analyzing the nation-building efforts of the Americans in the Plain of Reeds, Vietnam, David Biggs shows how this effort failed because the Americans "could not escape the landscape, webs of bureaucracy, and political movements that had been shaped by ninety years of colonial rule and ten years of anticolonial warfare." Some of the engineers moved back and forth among the French, the Vietnamese and the American domains. Biggs says that even today, the engineers and planners still occupy the same offices that were inhabited by the pre 1975 and 1954 agencies. See David Biggs, "Breaking from the Colonial Mold: Water Engineering and the Failure of Nation-Building in the Plain of Reeds, Vietnam," Technology and Culture 49, 3 (July 2008): 599-623. Also for more on this continuity, see Elizabeth Lunstrum, "State Rationality, Development, and the Making of State Territory: From colonial extraction to postcolonial conservation in Southern Mozambique," in Christine Folke Ax et al. (eds), Cultivating the Colonies: Colonial States and their Environmental Legacies (Ohio, Athens: Ohio University Press, 2011), pp. 239-274; Andrew Bowman, "Mass production or production by the masses? Tractors, Cooperatives, and the Politics of Rural Development in Post-Independence Zambia," Journal of African History 52, 2 (July 2011), 201-221.
} 
England appointing Governor Rockefeller of New York as his personal representative with the rank of special ambassador to the independence ceremonies. ${ }^{504}$ Also appointed, as representative and special ambassador to the ceremonies by Eisenhower was Mr. Thomas Chauncey of Arizona. There were three other representatives of the US government at the event: Mr. Joseph Palmer, who was the Consul General at Salisbury, Mr. John K. Emerson, who was the Consul General at Lagos, and Mr. James K. Penfield, who was the deputy assistant secretary for African Affairs at the Department of State. America's independence gift to Nigeria was the provision of "books, library furnishings, films, projection equipment and related items up to value of approximately 100,000 pounds for the Institute of International Studies." ${ }^{\prime 05}$ The Nigerian government had proposed to establish such an institution as a center of learning and research on African and world problems. On the occasion of the independence, Governor Rockefeller brought a personal message from President Eisenhower to the Prime Minister of Nigeria, Alhaji Sir Abubakar Tafawa Belewa. After the usual congratulations to Nigeria for her independence, President Eisenhower then proceeded to write, "I am keenly conscious of the friendship which has marked the relations of our two countries. We take great pride in bonds established by Nigerian government leaders whom we are

\footnotetext{
${ }^{504}$ Eisenhower to Queen Elizabeth II, 21 September, 1960, NA II: 74H.02/9-2160.

505 US Consulate, Nigeria to US Secretary of State, 10 September, 1960, NA II: 745H.02/9-1060.
} 
privileged to receive as guests, and by the many Nigerians who have studied in our land."506

Many Nigerians were students in the US in the late twenties and beyond and many of these returned home to be voices of the independence movement. Chief among them was Nnamdi Azikiwe who arrived the US in the late 1920s and studied at Storer College, WV; Howard University, Washington DC; and Lincoln University in Pennsylvania before returning to Nigeria in the early 1930s. Through his influence, many other Nigerian students came to the US for their education. British officials in Nigeria did not encourage education outside of the country and the only college opportunity for Nigerian students locally was the Yaba Higher College located in Lagos. This college did not award degrees in the liberal arts. Instead it trained students to fill technical vacancies in the various ministries of government and their degrees were considered inferior to those that were earned from British colleges. 507 These Nigerian students, and in fact other West African students such as Kwame Nkrumah, who studied in the US, were pivotal voices in the independence movement. They formed alliances with their counterparts in the United Kingdom to fight British colonial rule. Azikiwe would become the first president of Nigeria, so as would Kwame Nkrumah in Ghana. Eisenhower's congratulatory message recognized these bonds that already existed with Nigeria and anticipated the pivotal role that the US would play in determining Nigeria's future. Nigeria was of an important

506 President Eisenhower's message on the occasion of Nigeria's independence, 28 September, 1960, NA II: 74H.02/9-2860.

507 Mazi Okoro Ojiaku and Gene Ulansky, "Early Nigerian Response to American Education", Phylon, 33, 4, (1972): 381. 
economic interest to the US. For example, in the published statistics by the U.S. Energy Information Administration, Nigeria was exporting about 6,000 barrels of oil per day to the United states in the 1960s and by 1976, the exports had grown to over one million barrels per day. ${ }^{508}$ While in comparison to the 1970s, the exports in 1960s were paltry, it must be noted that oil exploration and production was in its early years in Nigeria and large deposits of crude oil had already been discovered.

In his congratulatory message, President Eisenhower continued: "For the future, we in the United States stand ready to work with the people of Nigeria to reach the goals we all share of health, enlightenment and material well being. I am confident that in years to come our two countries will stand as one in safeguarding the greatest of all bonds between us, our common belief in a free and democratic way of life." ${ }^{09}$ It would be naïve for one to argue that his message was just a normal diplomatic message offered on such occasions. Nigeria was of great importance to the US economically and also strategically during this period of the Cold War as I have already shown in this chapter. The language in Eisenhower's message was suggested by the State Department. While this is not unusual, what is important is the cover letter that accompanied the suggested message from the State Department. In the cover letter, the acting secretary wrote: "Because of Nigeria's size and importance and the stabilizing role it will be able to play as a representative of the British Commonwealth in Africa, I recommend that a second message

508 U.S. Energy Information Administration, Annual Energy Review, 27 September, 2012, http://www.eia.gov/totalenergy/data/annual/showtext.cfm?t=ptb0504.

${ }^{509}$ President Eisenhower's message on the occasion of Nigeria's independence, 28 September, 1960, NA II: 74H.02/9-2860.. 
addressed to the people and government of Nigeria be available for release on September 30, the day prior to the actual independence date." 510 This he writes "would allow us to demonstrate the extent of American interest in Nigeria, not only in that country but elsewhere in Africa." ${ }^{\prime 11}$ Both the people in the State Department in Washington DC and the consulate in Nigeria understood the role that Nigeria would play in Africa and it was important for the US to safeguard its interest in the country. The population of Nigeria, the most populous African nation even to date and its moderate nationalists convinced the US that Nigeria would be a country it could work with and use as a beacon for promoting not only democracy but America's economic and political interest in Africa.

Nevertheless, it would not be the Eisenhower administration that would forge the strong development ties between the United States and Nigeria but the Kennedy administration. At the time of Nigeria's independence Eisenhower was serving the last months of his second term as president. He was basically a lame duck as the presidential election between Nixon and Kennedy would happen in about a month. John Kennedy won that election and he was sworn in on 20 January 1961. Earlier in this chapter, I presented Kennedy's views on modernization in the third world and how he enlisted men like Walt Rostow and the Rostovian disciples to help spread America's vision of the world in Asia and Africa. I showed earlier that Kennedy himself was a true believer in Rostovian theories and that was the reason he brought him into his administration and gave him and his disciples the kind of

510 Memorandum for the President, 26 September, 1960, NA II: 74H.02/9-2860.

511 Ibid. 
access they had toward US foreign policy. One disciple of Rostow that would have enormous influence in the development trajectory of Nigeria during this time period was Arnold Rivkin.

At this time, Rivkin was supposedly doing research on Africa. His Africa project at MIT had received the grant from Carnegie to enable his team to do research on Africa. He had both Archibald Callaway and Charles Nixon working in Nigeria. Also there was Wolfgang Stolper who was associated with the MIT African project working in Nigeria. The presence of Rostow, who had been associated with the CIS in the Kennedy administration helped to forge a strong collaboration between the CIS (African Project) people in Nigeria and the Kennedy administration. Rivkin's appraisal of Nigeria to Rostow was that Nigeria would play as important a role in Africa as India in Asia. ${ }^{512}$ Rivkin played an important role in convincing Rostow that Nigeria was the model country for the spread of the modernization gospel in Africa. It was the task of Rostow to influence the Kennedy administration's policy toward Africa, picking Nigeria as a model country for America's development efforts in Africa. This task, Rostow successfully accomplished. In March of 1961, Rostow informed Max Milikan, the director of CIS, that the White House had "selected Nigeria as the African country which it is important for us to deal with in a successful way." ${ }^{13}$ Rostow also wanted to know if MIT had some studies already they could use in estimating the kind of five-year plan that Nigeria could or should

512 Grubbs, Secular Missionaries, 87.

513 Ibid. 
produce. Milikan relayed this message to Stolper. ${ }^{514}$ Rostow was very much aware that MIT CIS had people in Nigeria and he also knew that Stolper was helping Nigeria with its development plan. Basically, he was requesting for Stolper's work on the Nigerian development plan.

\section{The United States Special Economic Mission}

On 5 May 1961 Stolper found out from Toby Lewis that the United States would be sending a special economic mission to Nigeria on 16 May. Interestingly, Arnold Rivkin headed this Mission. The news had been communicated by Ambassador Palmer to the prime minister that the United States was willing "to commit itself for a number of years to sizable sums" subject to congressional approval. ${ }^{515}$ The choice of Rivkin as the head of this mission was not a surprising one given his influence on Rostow and his acclaimed reputation as the most knowledgeable American on Sub-Saharan Africa. Stolper knew two people who were on the mission: Rivkin and Anthony Gerber whom he had worked with on the East German project. Stolper took interest in explaining to Lewis and George Dolgin who was the Economic Officer at the US embassy in Lagos, what the kind of person Rivkin was and what the expectations of these mission would be. In a kind of selfcongratulatory note, Stolper wrote in his diaries: "What they want to know and what they are prepared to offer is something of a triumph for me: It is just what I have been arguing we should do. This is perhaps not surprising, because I was after

\footnotetext{
514 Ibid.

515 Gray, ed., Diaries of Wolfgang Stolper, 106.
} 
all at MIT, and it is ideas from the Center for Foreign Studies which are now coming back at me...The Mission will want to know our resources, what we can finance ourselves, how many grants and loans we need."516 If there was ever any doubt that Kennedy's policy on Nigeria was being driven by the economic ideology of the Center, here you have the testimony of a man from the Center saying it as clearly as it could be said.

The US Mission arrived in Lagos on Tuesday, 16 May 1961. On 20 May, Stolper had lunch with them at Dolgin's home and later that evening took Rivkin for a swim. We do not know much of what Rivkin and Stolper discussed during that outing. Stolper's diaries tell us that he offered his home for Lewis the next day to brief Rivkin on the political situation in Nigeria. Toby and Rivkin were frank with each other during the meeting and Stolper found Rivkin impressive. Whether there was a connection between the previous day outing with Rivkin or not, Stolper does not tell us but he enthusiastically records in his diaries that, "I can take some credit for any success the American mission will have both for the US and Nigeria." ${ }^{17} \mathrm{My}$ reading of this statement following from the previous day's event is that Stolper must have used the social opportunity to impress on Rivkin the need for aid to be provided to Nigeria. The Mission met with the JPC on 22 May. Hansen presented a paper to them, which was based on an earlier paper written by Stolper. The members of the Mission asked questions based on the paper that was presented and Stolper was very impressed with their responses. He remarked that he "carried the

516 Ibid., 107-8

517 Ibid., 118. 
ball". Stolper gave Rivkin the second paper that he had written for the Mission. He shared this with him during a social outing while the rest of the Mission only received the paper the next day. ${ }^{518} \mathrm{~A}$ good rapport existed between Rivkin and Stolper and their association with MIT helped to foster this relationship. In the meeting that was held on 24 May, a question came from Rivkin on what Nigeria's reaction would be to an international consortium chaired by the IBRD in the manner of the "Aid India Club"? It was agreed that Nigeria would be favorable toward such a consortium provided it was not excluded from accepting aid from other sources that might offer it. ${ }^{519}$ Rivkin was surprised how easy it was for an agreement to be reached on this. He had expected a lengthy conversation on the topic. This was easy because Prasad, who was a World Bank man and the economic advisor to the prime minister, had done most of the legwork earlier convincing the prime minister to accept such a proposal. Rivkin's plan was to use such an international consortium to raise money to match the contribution that would be made by the United States..$^{520}$ The presence of Stolper in Nigeria made Rivkin's task much easier. As Larry Grubbs writes, "Stolper's influence within the Nigerian government made a meeting of minds almost automatic. The foundation had been laid, almost casually, for the future dominant role of the World Bank and multilateral lending processes in

\footnotetext{
518 Ibid., 119.

519 To fund development programs, the world bank had turned to setting up consortium of major lending countries. The Aid India Club was founded by the World Bank in 1950 to fund India's development plans. It was a consortium of countries such as the US, Germany, the UK, France, Japan, Canada, etc.

${ }^{520}$ Gray, ed., Diaries of Wolfgang Stolper, 120.
} 
Nigeria's economy." ${ }^{521}$ In one of the final meetings the Mission had with the Nigerian planners before leaving in June, Rivkin told them that everything was dependent on the "structure of the plan" and that the US would fund "a quality plan, not quality projects." Rivkin wrote to his former MIT colleagues telling them that he "enjoyed working with Stolper." 522

The Mission submitted its reports to the Director of President Kennedy's Task Force on Foreign Economic Assistance, Mr. Henry R. Labouisse on June 17, 1961. They wrote that the responsible officials in Nigeria were "cordial, forthcoming and cooperative" with them and that they discussed "their development plans at considerable length and answered the many queries of the Mission members with frankness and, wherever possible, in detail."523 The Mission's report on Nigeria was very glowing. It stated that Nigerians were hard workers and were determined to improve their standard of living. It noted that with the help of an economic advisor from the IBRD and American economists supported by the Ford Foundation and a small group of Nigerian economists, Nigeria was engaged in "attempting to formulate a national economic development plan" and to "establish priorities and quantify objectives" of the planning scheme. ${ }^{524}$ In praising Nigeria's determination and hard work, the report noted, "almost all of Nigeria's economic development in

521 Grubbs, Secular Missionaries, 87-88.

522 Ibid., 88.

523 US Government, Report of the Special U.S. Economic Mission to Nigeria, (Washington: Government Printer, 1961), iv.

524 Ibid., 5. 
the post-war period has been self-financed." ${ }^{525}$ This is not completely true as the British government made significant investments in Nigeria's economic development in the post-war period. What the report did was to try to construct a dominant narrative in which the US became the hero in its claim to remake Nigeria from a "blank slate." As I have shown earlier in the chapter, the 1962 plan was not really new. It built upon the colonial development plans. Also, many of the senior civil servants and experts in the Nigerian civil service were British. So, the attempt by Rivkin and the US to claim hegemony over Nigerian development, papered over a much more complicated reality, one with important late colonial connections and continuities.

The report also said that in the African context, Nigeria "stands out with respect to its potential for absorbing significant amounts of external reserves." 526 Though it's agricultural extension services were considered "poor to bad", and thus were identified as a priority to the forthcoming development plan. In terms of social justice, the report observed that Nigeria was one of the few countries in Africa "with a substantial and growing private sector involving an increasing participation of Nigerians' and it was one of the few African countries with free trade unions, a democratic constitution that was entrenched within its civil rights, and with an independent judiciary. Based on these findings, the report concluded that with regards to the President's "principal criteria for foreign assistance...Nigeria would appear to be one of the most promising candidates for economic development

\footnotetext{
525 Ibid., 6.
}

526 Ibid. 
assistance - grant and long-term loan - in Africa." ${ }^{27}$ The criteria which Kennedy had set forth for foreign assistance was long-term planning, self-help, absorptive capacity, and social justice. ${ }^{528}$ The Mission recommended that a second visit should be made to Nigeria around October to have more conversations with the officials in Nigeria while their plan continued to be under review. At the time the report was submitted, the Mission had estimated that external assistance to Nigeria for the fiveyear plan would be in the range of $\$ 762$ million to $\$ 882$ million..$^{529}$

The Mission returned to Nigeria on September 26, 1961. Again, Rivkin headed the mission and Stolper was at the airport to receive them. They had the first meeting with the JPC on September 28 with Prasad chairing the meeting. Prasad wanted to know how much aid the United States would give to Nigeria. Rivkin told him it depended on the plan and that no project was going to be evaluated "except in the context of the plan," and he hoped to have the plan before the Mission departed. ${ }^{530}$ Again and again Prasad kept pressing Rivkin at further meetings on the projects the United States would support but Rivkin's continuous response to him was that every project was going to be evaluated on the basis of the whole plan. The Mission left Nigeria at the end of October.

Rivkin's report had considerable influence in Washington and moved the Kennedy administration to commit $\$ 225$ million to the Nigerian national

527 Ibid., 8-14.

528 Ibid., 14.

529 Ibid., 98.

530 Gray, ed., Diaries of Wolfgang Stolper, 199-200. 
development plan. Larry Grubbs writes that, "The African Bureau of the State Department believed a long-term aid commitment to Nigeria would 'demonstrate the advantages of long-term planning,' and that with U.S. help, 'the moral equivalent of anti-colonialism could become 'the plan' throughout the region." Also, the head of the newly created USAID, ${ }^{531}$ Fowler Hamilton, advised President Kennedy "of the 'extraordinary' character of Nigeria's development plan, which he described as the 'first development plan of such scope and magnitude on the continent of Africa' and 'truly national in scope and purpose." 532 Two days after this advice, Kennedy approved the aid package to Nigeria. ${ }^{533}$ The news reached Stolper through Ambassador Palmer at a cocktail party given by the Ford Foundation on December 12,1961 . At first instance, Stolper was not too excited because the plan was going to cost $\$ 600$ million and he expected the United States to provide half of it. Seeing the sour reaction on his face, Stolper writes that, Palmer patted him on the shoulder and said to him: "It can get bigger." Stolper agreed that he thought it was a pretty good start. ${ }^{534}$ This approval of aid to Nigeria's development was a great victory for the evangelists of modernization to Nigeria. But was modernization really a success in Nigeria?

\footnotetext{
531 The USAID was created in November of 1961. It's primary responsibility was to administer civilian foreign aid.

532 Grubbs, Secular Missionaries, 88

533 Ibid.

534 Gray, ed., Diaries of Wolfgang Stolper, 235.
} 


\section{Problems with the Plan}

The goal of the "missionaries" of modernization to recreate Nigeria in the image of America failed. The promise that Nigeria was going to be for Africa what India was to Asia never materialized. The promise that India was also going to be the model of Asia did not materialize. ${ }^{535}$ Within a few years of the implementation of the Nigerian plan, the country's advance was derailed. Rather than becoming a great beacon of liberal democracy with strong civil rights, free enterprise with expanding economic growth, and social improvement in the lives of the people, Nigerian leaders were slaughtering each other and throwing the country into a civil war that would last almost three years and would have severe consequences for both the nation's economic and political future. The question that needs to be posed is: what happened in Nigeria? How could the US social scientists and the World Bank experts could have been so wrong about conditions in Nigeria?

The planners ignored or overlooked some important factors that could have derailed the plan. This Nigerian development plan had problems right from the very beginning, problems that were often ignored by the planners. I argue that there were four major problems that were responsible for the failure of the plan: regional differences; the problem of international "experts"; corruption; and the economic basis of the plan.

535 See Nick Cullather, The Hungry World: America's Cold War Battle against Poverty in Asia (Cambridge: Harvard University Press, 2010). 
Nigeria was/is a loose amalgam of hundreds of tribes and ethnic groups. Two amalgamations took place in Nigeria during colonial rule. In 1906, the British amalgamated the Lagos colony and the Southern Protectorate and in 1914, they amalgamated the Northern Protectorate and the Southern Protectorate creating what is known today as Nigeria. Apart from the numerous minority tribes scattered all over Nigeria, it has three major ethnic groups: the Yorubas, the Igbos and the Hausa/Fulanis. ${ }^{536}$ Throughout colonial rule, there were tensions between the different regions and ethnic groups. The regionalization of the colony in 1939 and the constitutional reforms introduced thereafter created a decentralized system where political elites and activities were directed to local and regional arenas. Political parties that were founded were not truly national parties but regional parties that carried with them strong regional biases. This made it difficult for the political elites who were responsible for the plan to set in motion a national vision of development. Beyond this was also the historical bias of the colonial state to the northern part of the country, which gained the most from the decentralized/regional system of government. These historical factors were at the background of this plan.

Stolper, the architect of the Nigerian plan confessed in his diary of not understanding the ethnic rivalries which he had to learn about over his tenure in Nigeria. I am doubtful how much he understood the conflicts and differences that existed between the regions. This is obvious in the final days of putting the plan

${ }^{536}$ For the history of Nigeria and the different ethnic groups, see Toyin Falola and Mathew M. Heaton, A History of Nigeria (Cambridge: Cambridge University Press, 2008). 
together. As discussed earlier, he did not understand why the prime minister refused that the regional plans should not be debated in the Federal Parliament and the federal plan should not be debated in the regional parliaments. This by itself should have sent a red flag about the effectiveness of the national plan, if we could call the final plan document, the national plan. This "national plan" was basically the three regional plans and the one federal plan together. In an ideal sense, the different regional plans should have been debated in the federal parliament to truly reflect a national vision for the country. The PM, who understood and appreciated the regional/ethnic conflicts and rivalries, knew such a plan could potentially be torpedoed because of regional/ethnic biases. The federal plan, which was part of the national plan, could not do much because the driving force of the Nigerian economy at this time continued to be agriculture and Stolper based his plan on the expansion of agriculture rather than industrialization, a contradiction of modernization theory which emphasized industrialization. The problem with the Nigerian plan however was that agriculture was not within the domain of the federal government but the regional governments. Each region had its own plans for agricultural development. The Eastern Region, for example, was dabbling into extensive agricultural settlement schemes with the Israelis, which Stolper confesses in his diaries added no economic value to the region and were bound to fail. Yet, such schemes were allowed to continue in what became the "national plan."

Though Arnold Rivkin understood that the ethnic conflicts were potentially a problem to the success of the development plan, he chose to believe that the 
development plan would become a cure to the problem of ethnic conflicts. He believed that economic development would create a "national economy" that would "allow Nigerians to transcend their ethnic, cultural, and regional differences and forge common national interests and identities." 537 It was naïve to think that a quickly put together economic plan would suddenly alter several decades of ethnic hostilities and colonial institutional structures and create a new Nigerian in the image of America. These ethnic and regional biases that became a major factor to the failure of this plan question the assumptions and biases of American social scientists and policy makers who in the 1950s and 1960s assumed that the problem with development in these regions of the world was a lack of proper prescription and tools to move these places to developed states. It is obvious that history, institutions, culture and traditions all matter.

The Nigerian development plan also suffered from the problem of international experts. Throughout this study, I have shown how developing Nigeria has been the work of foreign experts who came to the country and tried to impose their ideas on the country and its people. This has always met failure. This development plan suffered the same fate that the pre-independence development plans faced. One may argue that the Nigerian plan was a local plan drafted by Nigerians because the National Executive Council (NEC) and the JPC were involved in the design of the plan. ${ }^{538}$ Dibua, however, debunks this argument by noting that

\footnotetext{
537 Grubbs, Secular Missionaries, 93.

538 This argument is made by Allison Akene Ayida and referenced in Dibua, Development and DIffusionism, 76.
} 
the entries in Stolper's diaries demonstrate that Stolper played a "preeminent and dominant" role in drawing up the plan.. ${ }^{539}$ Beyond these arguments presented by Dibua is the fact that foreign experts heavily controlled these two institutions, the NEC and the JPC. The chairman of the NEC was the PM and he had as his personal economic advisor, a World Bank man, Narayan Prasad. The JPC itself was crowded with foreign experts and Western influence. Prasad and Stolper were the driving forces of this committee. It is also important to note that the initial chairman of this committee was the governor of the Central Bank who himself was British colonial expert. In this committee were also permanent secretaries who were British expatriates. It is hard to make an argument that this plan was a Nigerian plan. While Stolper stressed that the framework that was setup for development planning was geared toward forcing the formulation of the plan to start from the grassroots, he acknowledged that the roots did not go as deep as it would have been desirable. ${ }^{540}$ Even the regional plans, which one may argue, started from the grassroots, had foreign influence. A good example was the Eastern Regional plan. Not only was Stolper directly influencing the course of events in the Eastern Region; in his diaries, he made reference to an African American, Daniels, ${ }^{541}$ who had great influence in the region. ${ }^{542}$ Daniels was the head of the Industrial Division of the Eastern Region

\footnotetext{
539 Dibua, Development and DIffusionism, 76-77.

540 Wolfgang Stolper, Planning without Facts, 39.

${ }^{541}$ No first name given in the diary.

${ }^{542}$ Stolper in his diaries mentions that he asked Pius Okigbo, who was in charge of economic planning in the Eastern Region, for a copy of the Executive Committee paper that was only seen by ministers. With reluctance, Okigbo gave it to him on the promise that the paper should not be shared with anyone. Stolper's reaction in his diaries to the paper is this: "The information in it was pretty much what I had worked up with him when I was last in Enugu, but it was a courageous paper, laying down the law to the Prime Minister, pointing out that the ER financial situation was going to be
} 
Development Corporation. Stolper accused him of being an empire builder who wanted to "sink lots of money into crazy industrial undertakings, when it should go into palm grove rehabilitation and hydraulic palm oil presses." 543 There were thus visible and invisible hands of foreigners everywhere in the development of this plan.

The use of expatriate economists came under criticism early on in the development of the plan by a Nigerian economist Ojetunji Aboyade whom Stolper speaks highly of in his diaries. ${ }^{544}$ Aboyade noted that the Nigerian government took the view that "indigenous economists were either unavailable or incapable of carrying out the technical responsibility." Though he believed that the economists that were sent to Nigeria were able economists, he writes that, "There is no doubt that they have not come from an economy with an image of strong planning tradition." ${ }^{45}$ It was paradoxical that Stolper and his US based team would recommend central planning for Nigeria when the US did not use strong central planning in the development of their own economy.

Aboyade's argument that the Nigerian government should have used Nigerian economists is somewhat contradictory. As Inderjeet Parmar argues, these elites were "developed and nurtured by British colonials and supported by American aid. Its nationalism was always skewed toward reliance on the West for

desperate, that the Plan had to stress high and quick payoff projects, if the Region is not to bog down, and that more taxes would be needed." Gray, ed., Diaries of Wolfgang Stolper, 129.

543 Ibid., 129-30.

${ }^{544}$ Ojetunji Aboyade was a professor at the University College, Ibadan. He later succeeded Stolper as advisor to the Federal Government for the second Five Year Plan.

545 Aboyade, Foundations of an African Economy: A Study of Investment and Growth in Nigeria (New York: Frederick A. Praeger, 1966), 154. 
defense, trade, ideology, and legitimacy." 546 What is also true is that Nigerian economists and educated technocrats who did not hold onto the pro-western viewpoints were branded as "communists" and legislated against for employment in the Nigerian civil service. ${ }^{547}$

Despite the Western influence on Nigerian economists and political elites, it is important to make distinctions between the colonial approach and the American approach. In the colonial period, some colonial officials tried to understand the local conditions and context and conducted research to see what improvements would be more successful and appropriate. The Americans did not follow such a thorough approach. Be that as it may be, Nigerian economists were in better position to understand the needs of the Nigerian people than the expatriate economists. As Aboyade argued, it was not that Nigerian economists were scarce; it was that they were "being inefficiently used in sub-optimal occupations." 548 Nigerian economists should have been used primarily in the design of the plan, with expatriate economists playing supporting role. It was however determined by the Nigerian political class that these foreign experts would be more suitable to carry out the task of planning.

Corruption was another problem that the planners had seen during the development of the plan. Stolper in his diaries chronicles corruption that had already infected the Nigerian government. During his first tour of Nigeria, he was

546 Parmar, Foundations of the American Century, 176.

547 Ibid., 173.

${ }^{548}$ Aboyade, Foundations of an African Economy, 153. 
told of the "high degree of corruption that existed and enrichment by local robber barons" and how these ill-gotten goods are stacked in accounts in Switzerland. ${ }^{549}$ In February of 1962, Stolper mentioned in his diary how Festus Sam, the Finance Minister and Theophilus Otunba Benson, the Minister of Information, split a substantial contract of TV contracts. He then remarked, "What do they care about the development program as long as they can control the contracts." ${ }^{550}$ Stolper's own minister, Waziri Ibrahim told him of the rampant corruption going on and even wanted the contracts to be transferred to the prime minister's office but the PM objected. ${ }^{551}$ Though Stolper thought of Festus as a very corrupt minister, a few days later, he stated despite Festus' "greed and corruption is a darn good finance minister." 552 One is left to wonder what his definition of "good" was. The corruption that was already endemic in the system was bound to continue during the implementation of the development plan although Stolper believed that he had safeguards in the plan that would help check the corruption. Part of the reasons the plan would fail would be the corruption. Contracts were awarded to cronies with inflated amounts and the plan was rapidly running out of money.

The final problem I find with this development plan is it's economic basis. Stolper's plan favored "short-term benefit over long-term investment, free movement of capital, unhindered repatriation of profits by foreign corporations, and

\footnotetext{
549 Gray, ed., Diaries of Wolfgang Stolper, 8.

550 Ibid., 246.

551 Ibid.

552 Ibid., 252.
} 
complete opposition to nationalization." ${ }^{553}$ For a country that was only beginning to find its economic footing in a global economy, this was a bad economic prescription. The plan was devoid of strong social services that would have led to long-term rather than short-term growth. Yet such services were necessary for the long-term expansion of the economy. The few corporations that were existent in Nigeria were mainly foreign and not local and Nigeria did not even have a stock market yet. This only helped in facilitating capital flight that was bad for Nigeria's economic expansion. Stolper's anti-state ownership plan was bias toward free and private markets.

\section{Conclusion}

This chapter has shown that history, institutions, people and culture matter when it comes to development planning. Nigeria was not a blank slate to be written upon by the planners of the 1962 pllan. The vision of American social scientists such as Rivkin and Stolper to remake Nigeria was cut short by the Nigerian civil war. Even before the war started, it had become obvious that the goals of the plan were not going to be realized. Rather than the plan helping to build a national consensus that Rivkin had predicted, Nigeria was further driven apart. The bold pronouncements of the missionaries of modernization to remake Nigeria remain pure rhetoric as they faced the reality of the local conditions. As this study of Nigeria has shown, in practice, modernization theory did not put many new concrete ideas on the table. Many of the colonial era policies, most especially in the agricultural

\footnotetext{
553 Parmar, Foundations of the American Century, 175.
} 
sector were continued. Where modernization theory derailed from colonial era attempts to understand local contexts, the consequences were significant. On the whole, "postcolonial" development did not mark a break from late colonial development. 


\section{CHAPTER SIX}

\section{Conclusion}

I started this dissertation with a vignette which explains my "historical turn" to find answers to why Nigeria experienced a socio-economic decline beginning in the 1980s and continuing well into the new millennium. In the course of my study, I discovered that in order to understand this decline, it is important to go back further into history to find the roots of the developmentalist agenda. This is important as it helps to link the practice of development with the ideas and discourse of development. Linking both reveals an approach to development that was not linear or guided by a singular agenda. One discovers varied agendas that had significantly shaped the practice of development. The starting point for this study was 1900, the year of Britain's official colonization of Nigeria. Though the colonial state opened up the interiors of Nigeria for effective colonization and for the onward transfer of the resources of the colony to Europe, development was not institutionalized until the period after the Great Depression. What was important in this earlier historical phase was subjecting the people under British imperial rule and exploiting the resources of the colony to help Britain in its mission.

The post-World War II development program that would become a characteristic feature of late British colonial rule emerged during the Great Depression. This started with the passage of the 1929 Colonial Development Act. Even then, this Act was more or less a job creation program for British citizens as its sole intention was to deal with the problem of unemployment in Britain. Coordinated planning for development of the 
colonies started after the depression in response to the deplorable social conditions of the colonies and flourished in the period after the war with the passage of the $1945 \mathrm{CD} \& \mathrm{~W}$ act.

The 1945 CD\&W Act was the revision and expansion of the 1940 CD\&W Act. This earlier act was not implemented because of the war. The bulk of the planning that became part of Nigeria's development plan in 1945 was done for the 1940 act and later in anticipation of the 1945 act. By the time that the British parliament passed the 1945 act, Nigeria had already drafted a substantial portion of its development program. It was for this reason that the Secretary of State at the time, Oliver Stanley, thought that Nigeria's plan would be a model for the other colonies. In delimiting this study, it was important to begin in 1945 because the 1945 CD\&W Act and the Nigerian ten-year development plan that arose in response to it was the first attempt at long term planning and the first time that substantial resources were made available for the development of the colony. By studying this plan, it becomes evident that colonial development, like colonial rule itself, was plagued by contradictions and thus it is important not to use outcomes to judge intentions.

The initial goal of taking this study through to the 1980 s in order to answer the question that prompted my enquiry became infeasible because to cover such a large period of time meant a lot of important events had to be sacrificed, chief among them the 1967 Nigerian Civil War that had the greatest physical impact on Nigeria's development history as both humans and infrastructure were destroyed during the war. The destruction and reconstruction that resulted from the war deserve a separate treatment. Another major event that happened was the 1970s oil boom and the rapid expenditure of money by the 
Nigerian government on infrastructural development during this period. What also happened with the boom was the neglect of agriculture that had been the main economic resource of Nigeria from colonial times up to that moment. That alone deserves another separate study. My work ends with the 1962 plan because I believe that the period after the Nigerian Civil War belongs to a separate study and should not be lumped into the earlier period considered in this work.

This work has revealed that the independence of Nigeria in 1960 was not the rupture of colonial development. The real break was the Nigerian Civil War of 1967. Some of the gains that had been made in the last twenty years of development in Nigeria were destroyed by the war. However, the war did not end development planning. At the end of the war, three more development plans were launched: the 1970 plan, the 1975 plan and the 1981 plan. The 1970 plan was a four-year plan. The plan was intended to not only reconstruct the infrastructure that was destroyed during the war but also to reconstruct the economy that had been negatively impacted during the war years. Agriculture was very much a part of this plan. Agriculture was the third most important sector in the plan. Transportation received $23.7 \%$ of capital allocation; the public sector as a whole received $13.5 \%$ and agriculture received $10.5 \%$. In actual expenditures, $23.1 \%$ was spent on transportation, $11 \%$ on education and $7.7 \%$ on agriculture. Industry received $3.9 \%{ }^{554}$ In the midst of the implementation of this plan, Nigeria experienced an economic boom. This boom was as a result of the Arab oil embargo of 1973. This caused the price of oil to spike. As a result, Nigeria's foreign reserves rose from $\$ 222$ million in

\footnotetext{
554 Daily Times, 8 May 1973. Article written by V. P. Diejomach. It is entitled: "Comparative Analysis of Second and Third Plans".
} 
1970 to $\$ 5.203$ billion in 1976. Nigerian oil revenues grew from 1.4 billion naira in 1973

to 12.86 billion naira by $1980 .{ }^{555}$ What emerged during this time was the increase in public expenditure and a decline in the agricultural sector. There was evidence of the "Dutch disease. ${ }^{, 556}$ Nigeria became a rentier state.

It was during this time of boom that the third national development plan was launched. The president of Nigeria at the time, General Yakubu Gowon, is believed to have remarked that the problem of Nigeria was not money, but how to spend it. The third plan was "the largest, most ambitious and imaginative development programme ever launched, not only in Nigeria but in the whole of black Africa." ${ }^{557}$ This plan was intended to accelerate the growth of the economy and to increase the standard of living of the people. Agriculture and mining was expected to contribute $55.5 \%$ of the GDP by the end of the time period. Agriculture and mining accounted for 68.9\% of GDP in 1974. Agriculture received about $11 \%$ of total public capital investment. There was an urban bias underpinning this plan as industry received $11.5 \%$, transportation $37.5 \%$ and urban development $9.0 \% .{ }^{558}$ Massive road constructions were carried out in urban areas.

Moreover, the civilian administration of Alhaji Shehu Shagari that came to power in October of 1979 continued the tradition of development planning. This administration launched the fourth development plan in 1981, which was billed as a four-year plan. Due

\footnotetext{
555 Ezekiel Ayodele Walker, "Structural Change, the Oil Boom and the Cocoa Economy of Southwestern Nigeria, 1973-1980s," The Journal of Modern African Studies 38, 1 (2000): 71.

556 The Dutch Disease is a concept used in economics to explain the relationship between the increase in the exploitation of natural resources and the decline in local manufacturing. When natural resources are exploited and exported, the currency of the nation becomes stronger and this causes the nation's exports to become too expensive. Brian Pinto, "Nigeria During and After the Oil Boom: A Policy Comparison with Indonesia", The World Bank Economic Review, 1, 3 (May, 1987): 419.

557 Gordon Idang, "The History of Planning in Nigeria," Administration for Development in Nigeria, Paul Collins, (ed.) (Lagos, Nigeria: Africa Education Press, 1980), 24.

558 Ibid., 25.
} 
to declining oil revenues, the plan could not be effectively implemented. By 1985, Nigeria was in a deep financial crisis and had to resort to IMF/World Bank loans. Nigeria was forced to embrace neo-liberal economic policies that promoted the free market and advocated the sale of government public enterprises. This ended an era of multi-year development plans that started in the colonial period.

This work has also shown that there was a high level of continuity in development between the late colonial period and the early "postcolonial" period. The development policies of the late colonial era were continued after independence despite the lack of success. Both plans lacked both the financial and human resources that were needed for successful implementation. In both cases, there was a strong presence of foreign "experts" both from America and Britain in Nigeria, who helped to midwife the development agenda.

Having studied the 1945 and 1962 plans, it is evident that in both cases the outcomes lagged behind the goals. Social and economic progress remained very slow in the late colonial period and in the "postcolonial" period. The lack of socio-economic progress and the entanglement with regional politics plunged Nigeria into the civil war. It is also commonplace to blame corruption and poor implementation as culprits for the failure of development in Nigeria or actually in most nations in the global south. This study has challenged that assumption and has argued that there were other factors responsible for the failure of development. While corrupt Nigerian politicians may be a factor in the "postcolonial" plan, a fact that the drafters were very much aware of, they (the Nigerian politicians/ elites) were not responsible for the late colonial plan. Granted that these plans were poorly implemented, it still does not fully explain the failure of the 
plans. Thus, it is important to look beyond implementation to the planning process, a task that this study undertook. This study reveals that the failure of the plans stemmed from the planning process. There were a myriad of problems that plagued these plans from the time they were put together and even if they were perfectly implemented as planned and there was complete absence of corruption, the plans would still not have brought about rapid social and economic progress. In the case of the two plans examined, this study can identify five factors that had a significant impact on the failure of the plans: Development ideology, human resources, financial resources, international experts/indigenous knowledge, and corruption.

\section{Development Ideology}

One of the ideological debates in the late colonial period and even in the "postcolonial" period was the question of whether social welfare led to greater economic development, or vice versa? During the formulation of the 1945 plan, this was one major area of disagreement between Sydney Caine of the $\mathrm{CO}$ and the Nigerian officials who were negotiating development. Caine saw the foundation of development as economic growth and productivity and argued that the resources that are generated through these could then be invested in social services. The Nigerian officials argued that the basic needs of the people needed to be provided before one could require more from them toward economic growth. While the colonial administration carried out some welfare projects as part of its development of the colony, the planners of the first Nigerian National Development plan were less interested in funding social welfare projects. For example, only 2.5 percent was allocated to health and 0.7 percent allocated to social 
welfare in the federal plan. ${ }^{559}$ These planners believed that economic expansion would lead to better social conditions. In a sense, this was trickle-down economics.

This became a major weakness of the "postcolonial" plan and in a sense even the late colonial plan. Though the late colonial plan had social welfare elements, the level of investment in such programs was too insignificant to leave a serious dent in the social welfare needs of the people of the colony. Both plans were over reliant on the export of agricultural products for economic expansion and provided little investment in social welfare. This imbalance was a big reason that social and economic progress was slow. What this meant was that they were only planning for short-term results and not for the long-term development of the country. For example, building more high schools and universities may not have improved the GDP of the country in the short term but a good and expansive education system was sure to build a strong foundation for the future of the economy. In 1962, there were only five universities with about fourteen hundred students enrolled. The Eastern and Western regions alone had over 30,000 students enrolled in the secondary schools. The absorption capacity of the universities meant that only a tiny fraction of secondary school graduates could enter the universities. If the planners were not limited by short-term economic growth, more investments would have been made in education and other social welfare programs. The results from investing in schools would not have been realized for five or even fifteen years but in the long run, they would have been good for the economic growth of the country. The reason is that schools are engines of growth as they fulfill the mission of being places for the development of human capital. Nigeria suffered from the dearth of human power in the

\footnotetext{
${ }^{559}$ Federation of Nigeria, National Development Plan, 51.
} 
late colonial and early "post-colonial" period because the colonial state failed to invest earlier on in higher education. The failure to make meaningful investments in higher education and other social welfare programs in the Nigerian plans rested on a development ideology that favored short-term economic growth over basic needs.

\section{Human Resources}

The failure of the colonial state to develop human resources through significant investments in education became a major problem for development not only in the late colonial period but also in the period after independence. This was not a problem that eclipsed the minds of the planners. The 1945 plan called for the use of development officers. The planners argued that they could not source them in Nigeria. They had to cast their nets wide, as far as Canada even, to recruit such officers for development work. And these officers were not even technical staff. The recruitment of technical staff posed an even bigger problem. They could not find enough irrigation engineers or agricultural supervisors to carry out development work in Nigeria. The few technical staff they had were saddled with enormous responsibilities which meant it was almost impossible for them to carry out their assignments effectively. For example, one irrigation engineer had to cover a whole province. The same was true for agricultural officers. The area allotted to them for supervision was too large.

James Mackie had foresight when he identified this problem as one that would be a stumbling block to the development of Nigerian agriculture. He pushed very hard for a university in Nigeria devoted to training agricultural officers. Mackie's goal of having an agriculture university in Ibadan associated with the Moor Plantation was never fulfilled. As early as 1921, an agricultural training center was established in Samaru, Northern 
Nigeria. In 1932, this was converted to an agriculture training college. It was not a college that offered bachelor or advanced degrees. Graduates were trained as agricultural assistants and it remained so even after the independence of Nigeria. The college is today affiliated with Ahmadu Bello University, Zaria and it offers the National Diploma and the Higher National Diploma. Samaru's graduates were limited in what they could do because they did not have the kind of advanced specialized training in tropical agriculture, as did the expatriate agricultural officers that had studied at the Imperial College of Tropical Agriculture in Trinidad. In the period after independence, Nigeria had to continue to rely on expatriate agricultural technical staff.

The same was true of other aspects of the Nigerian bureaucracy. In the period after independence, many heads of service were British, many technical officers, college professors, secondary school principals and so on were expatriates who continued to provide services to Nigeria. The lack of human resources meant that the state was limited by what it could do. The fear that they may not find the needed human capital for projects prevented them from adopting more bold projects. This was more so with the 1945 plan than the 1962.

\section{Financial Resources}

The problem of inadequate financial resources was one that plagued both plans studied. The financial resources needed by Nigeria were greater than what was available for development. This study has shown that the figure that was arrived upon by the British government for development was a random figure without any careful study of what the financial needs of the colonies were. The S of S, Oliver Stanley, had requested $£ 150$ million for development. This figure was not based on any careful statistical 
analysis of the economic and social needs of the colonies. The Chancellor of Exchequer would only agree to $£ 110$ million which he broke down to $£ 10$ million a year and an additional $£ 1$ million a year specifically for research. They arrived at a compromise of $£ 120$ million. Nigeria was to receive $£ 23$ million. Nigeria’s plan called for $£ 55$ million. The rest of the money was to be sourced by the Nigerian government through loans, increased taxation, etc. Like the problem of human resources, it was obvious to the planners that Nigeria would have problems contributing financially to its own portion of the development plan. An argument was made that Nigeria should receive in the early years of the plan a sizeable portion of the grant from the $\mathrm{CD \& W}$ fund with the hope that in the later years of the plan, some of the economic benefits of the plan would have started to take effect and Nigeria would be able to sustain development and recurring expenditures. An example was in the recurrent expenditures such as the hiring of new staff. The Nigerian colonial government wanted CD\&W funds to pay the salaries of these staff because they could not afford to pay the salaries from their own revenues. The hope was that toward the end of the ten years, Nigeria would see sufficient economic expansion to enable it pay the salaries of these staff. By 1950, the plan was revised and broken into two five-year periods. The amount of resources that was committed to the development of as large a territory such as Nigeria remained meager and as a result, the plan had to focus on specific sectors such as transport, communication and agriculture. The focus of agriculture was on cash crops with the idea being that these would help generate the needed revenue for further development.

The 1962 plan, like its 1945 predecessor, also was starved of needed funds for effective development. The architects of this plan were aware of the problem. The lack of 
funds was one of the major contentions between Prasad and Stolper. Prasad told the regions to go ahead and plan as the money would not be a problem and Stolper wanted to limit the cost of the plan. At the end, it was difficult for the regions to get the money they requuired for their development needs. Even the $\$ 225$ million that was promised by the United States was not forthcoming as they had to write grants and qualify for it. The Nigerian leaders thought that since the plan had received the approval of the US Economic Mission led by Arnold Rivkin and the \$225 million promise was based on the plan, the money would simply be given to them. They soon found out that they had to go through an extensive approval processes from the US for each project they wanted to carry out before they could receive the grants. Receiving development money and loans from around the world became a major preoccupation of the Nigerian leaders and they were never able to fully implement the plan because of a lack of financial resources.

\section{International Experts/Indigenous knowledge}

Development planning in late colonial and early "postcolonial" Nigeria was primarily the work of international experts. In the late colonial period, this was done with little input from the local Africans. Colonial Officials dominated development committees and the few Africans present were ex-officio members. It was not the Africans that chose the projects that were part of the development plan. What this means is that development planning ignored the voices of the local people as well as indigenous knowledge. The international experts were both the producers and custodians of knowledge, isolating the indigenous people from this important process. In the fourth chapter of this dissertation, the Niger Agricultural Development Scheme in Mokwa provided a good case study of how this process had severe consequences for late colonial 
development. This scheme, by far the largest agricultural development scheme in colonial Nigeria, was planned and executed without any input from the locals. The Oilseeds Mission that came to Nigeria conceived it; the CO supported it and convinced the CDC to partake in it; it was planned and executed by the Nigerian government, the CDC and the managing company, NAP. International experts ran NAP with no input from the locals. Had local knowledge been consulted some of the problems that plagued the scheme would have been avoided. It is however important to note that the approach to the setting up of Mokwa was a break from the pre-1945 period when agriculture officers such as James Mackie advocated careful field trials and experimentation as well as learning the local conditions and the practices of the people. NAP failed because of the planning experts ignorance of the culture, topography and farming practices of the locals and their refusal to consult them in the planning process

This problem was not limited to the colonial period. In the "postcolonial" period, the use of international experts from the United States and the World Bank to design the plan also was responsible for the failure of the plan. In the conclusion of the fifth chapter of this work, this problem has been discussed in detail and the chapter shows how these experts contributed to the failure of the plan. Though there was a stronger African agency in this plan as Nigeria was already an independent nation, the role of Nigerians was still negligible because they were working within the economic framework that was handed over to them by Stolper and his team of development experts.

\section{Corruption}

Development planning was also besieged by corruption. The designers of the 1962 plan were very much aware of this problem and the fifth chapter has carefully 
looked at this problem. Beyond the corruption of the Nigerian leaders, there was also a corrupting influence that lay at the heart of the plans themselves. To put it succinctly, plans were corrupt. In the late colonial period, the projects that were funded were skewed toward the benefit of the British. Emphasis was on cash crops to help with the balance of payments problem Britain was facing and the transportation and communication systems that also occupied a significant part of the plan were to help facilitate the onward transfer of goods from Nigeria. That the projects funded by the late colonial plan were solely for the benefit of the British was corruption of the highest order. Nigerians were meant to believe that the colonial government was helping them with development. They even congratulated Her Majesty’s government for her contribution of $£ 23$ million from the $\mathrm{CD} \& \mathrm{~W}$ vote. Nigerian people had to come up with the remaining $£ 32$ million to fund the plan, money that was borrowed on the backs of future generations of Nigerians. However, the primary beneficiary of development was not going to be the Nigerian people but the British. How different was the British government from the corrupt Nigerian leaders who in the "postcolonial period" tried to fund projects of which they were going to be the primary beneficiaries?

\section{Conclusion}

In this work, I have shown both the British and American influences in development planning in Nigeria and I have shown the shift from colonial led development to American led development. I believe this is a unique contribution to the scholarship on development planning in "British West Africa." I have also shown in this

work that the characters and institutions that design these development plans are important in understanding development planning. Devoting a substantial portion of the 
work on colonial officials both in London and in Nigeria and on other major figures such as James Mackie, Wolfgang Stolper, and Arnold Rivkin has helped to shed light on the ideology that drove these plans and also on the human element. Mackie had an approach to agriculture development that emphasized research and extension. His agriculture department found itself constantly in ideological fights with the political department. This eventually caused him to resign from Nigeria shortly after submitting the agriculture proposal. This had an impact because for more than a decade, he had been working on that proposal and he did not believe that he was going to be given the freedom he needed to implement it. Stolper on the other hand had to deal with Narayan Prasad, the adviser to the prime minister. Their disagreements got very personal and this also stood in the way of the plan as they gave conflicting advice to the regional governments. Though Rivkin was not caught up in any of the Nigerian feuds, he had a personal agenda to recreate Nigeria into a capitalist democracy like America. In the process of doing this, he took for granted the strong ethnic biases and tensions that existed in Nigeria and had a naïve view that the fulfillment of such a dream would eliminate those biases and tensions. He gave the Nigerian planners a false hope that America was going to adequately fund a good plan. The plan was written to fit the United States expectations. At the end, the US did not come through with all the promised funding.

Studying these individuals as well as the institutions that supported them is important to understanding the development process. That is the approach that this dissertation has followed. I believe this approach is a unique contribution to the scholarship in colonial and "post-colonial" development planning. More work remains to be done in this field and most especially as it relates to British West Africa and more 
specifically, Nigeria. There is need to explore more the major influences of the post-civil war development plans. Also, within the time period covered in this dissertation, more work needs to be done, approaching the subject from the perspective of the locals who were not responsible for the planning but were drafted to help execute these plans. By these, I mean the settlers and their families, the civil servants who had to take orders and the farmers who were told to cultivate certain crops over others. Their response to the development plans is helpful in understanding how they helped shaped the implementation of these plans. This is a goal I have given myself for future research. 


\section{EPILOGUE}

A question that up until now has remained unanswered in this dissertation is what accounts for the changes that took place in my neighborhood and in Nigeria as a whole between 1995 when I graduated high school and 2010 when I returned to the neighborhood? As I look back, the changes did not begin in 1995 but were several years in the making. Living through them did not allow me to see how dramatic they were. Stepping out of that environment for several years and returning there allowed me to appreciate how significant they were. Electricity had stopped being very regular before 1995, so did public water supply. All these kept getting worse over time because of neglect, and today are almost in a state of complete disrepair.

Though problems started cropping up beginning with the falling oil prices in the late 1970s and early 1980s, it was however the imposition of IMF Structural Adjustment Programs in the late 1980 s that was the death knell to social services. The Nigerian currency, which up until that point was stronger than the US dollar, was significantly devalued and since then it has been almost in a free fall. Even with the Nigerian government using its foreign reserves to shore it up, it is still exchanging at N170 (Naira)

to a dollar and sometimes even higher on the black market. The devaluation of the currency led to runaway inflation. Between 1986 when SAP was introduced and 1989, Nigeria's inflation rose from $5.4 \%$ to $40.9 \%$. Inflation forced the interest rates to go up which in turn discouraged investment. Also, the prices of domestic products went up relative to those of foreign products and this inhibited exports while at the same time stimulating imports, thus “depleting the nation's scarce foreign reserves and worsening 
the balance of payment position." 560 The rise in prices of domestic products and the inability of producers to export these items meant a significant loss of income for local producers. Farmers were more reluctant to produce cash and food crops if their products were not able to compete with the prices of imports. The decline in agricultural production affected the lives of a majority of Nigerians who continued to rely on agriculture for their livelihood. Nigeria in the late 1980s did not only go through a food crisis but also massive poverty. As Nigerians then joked, "SAP has sapped life out of us."

The economic situation of Nigeria exacerbated poverty in rural areas, as there was high unemployment. The resultant effect of this was a large number of people migrating to urban areas with hope of finding jobs. This migration created its own problems as the urban areas did not have the resources and facilities to accommodate the growing population. The Nigerian government's solution to the problem of poverty in the rural areas was the introduction of two programs: the Directorate for Food, Roads and Rural Infrastructure (DFFRI) and the Better Life for Rural Women. DFFRI was established in 1987 and its target was "to provide water for 250 communities in each of the states of the federation, to construct $90,000 \mathrm{~km}$ of feeder roads, and to promote rural housing, health and agriculture. To facilitate industrial growth, and improve the attractiveness of the rural environment...."561 This program was criticized for making false claims on the roads constructed, as well as receiving poor funding and not engaging in any direct food production. ${ }^{562}$ As with most Nigerian programs during this time period, it was marred by

\footnotetext{
560 John C. Anyanwu, "President Babangida’s Structural Adjustment Programme and Inflation in Nigeria," Journal of Social Development in Africa 7, 1 (1992): 14.

561 L. M. Olayiwola and O. A. Adeleye, "Rural Infrastructural Development in Nigeria: Between 1960 and 1990 - Problems and Challenges," Journal of Social Sciences 11, 2 (2005): 94.

562 Anyanwu, “President Babangida's Structural Adjustment Programme and Inflation in Nigeria,” 16.
} 
corruption. The wife of the president of Nigeria, Maryam Babangida and with the financial backing of the Nigerian government established Better Life for Rural Women in 1987. Its focus was on empowering rural women toward growth and development. It helped women's organizations establish cooperative farms and cottage industries. The impact of these interventionist programs by the government was negligible as they were unable to stem the tide of rural poverty.

The financial crisis, which had started from the early 1980s, reached its peak by 1992. The neoliberal economic policies which were introduced from 1986 did not help the economy to grow but actually saddled the country with more debt and a high rate of unemployment. From 1986, the government started privatizing public enterprises and merging some. Many workers were retrenched from government services and even those who still had jobs did not show up to work because the government owed workers several months of salary. The government became unable to invest in social services because it lacked the resources to do so. $47 \%$ of the overall budget of the government went into debt servicing and little was left for public investments. For example, prior to 1982, the government spent more than 6 percent of total expenditure on education, but by 1992 , less than 1 percent was spent on education. As Olumide Ekande argues, "This had severe repercussions for infrastructure, teaching, and research activities, and on the quality of students produced. It affected the morale of teachers who were owed arrears of salaries for several months and who had to abandon their duties out of necessity to seek other means of sustenance."

\footnotetext{
563 Olumide Victor Ekanade, "The Dynamics of Forced Neoliberalism in Nigeria since the 1980s," Journal of Retracing Africa 1,1 (2014): 11.
} 
The root of today's crumbling infrastructures has been in the making for decades because of corruption, the mismanagement of the economy and the introduction of neoliberal economic policies that favored economic growth and expansion over social welfare. Recently, Nigeria's economy was declared the largest in Africa after a rebasing calculation determined that its gross domestic product was more than $\$ 500$ billion and the economy was determined to be growing at over 6 percent a year. For the over 70 percent of Nigerians living in poverty, this means nothing as they continue to experience poor social services such as failing schools, rationed electricity, pot holes laden roads, and other crumbling public infrastructures. Most Nigerians who have the financial means do not educate their children in public schools but in private schools. Even families with very modest incomes have to purchase power generators because the National Electric Power Authority (NEPA) is now an acronym for Never Expect Power Always. As I look back, there was no private elementary school or secondary school in my town when I was a child. Today, there are over twenty. What Nigeria is going through today is economic growth without development. 


\section{Bibliography}

\section{Primary Sources}

Bodleian Library of Commonwealth and African Studies (BLCAS), Rhodes House, Oxford

Mss Brit. Emp. S. $332 \quad$ Arthur Creech Jones Papers

Mss Afr. S. $2124 \quad$ J. R. Mackie Papers

Mss Afr. S. $823 \quad$ J. R. Mackie Papers

Mss Brit. Emp. S. $476 \quad$ Oxford Development Records Project (ODRP) Food and Cash Crop Collection

The National Archives, Kew, London

Series CO $554 \quad$ West Africa: Original Correspondence, 1944

Series CO 583

Series CO $847 \quad$ Africa: Original Correspondence, 1937-1950

Series CO $852 \quad$ Economic Department: Original Correspondence, 19351952

Series CO $879 \quad$ Confidential Print: Africa 1895-1945

National Archives II, College Park, Maryland

Record Group 59, Records of the Department of State

Decimal Files $\quad$ British Territories in Africa

British West Africa

Nigeria 
Lot Files

Records of the Bureau of African Affairs

Bureau of African Affairs, West African Affairs

Country Files, 1951-1963

The Nigerian National Archive, Kaduna

File No. $2726 \quad$ Irrigation Policy Northern Region

File No. $2705 \quad$ Irrigation Schemes: Niger Province

File No. 26902/ S.1 Irrigation in N.R. (Northern Region)

File No. 26902/ Vol.II Irrigation in the Northern Provinces

File No. $7823 \quad$ Policy and Minutes of Discussions, Minna Division

File No. $7503 \quad$ Policy and Minutes of Discussion, Kabba

File No. $11703 \quad$ Agricultural Policy in Northern Region

EPD/E/168 Northern Region Agricultural Research Scheme: Financing

of.

MIT Institute Archives, Massachusetts.

A2236 Politics of Transition: Proposals, 1960.

Government Publications

NIGERIA

Nigeria. A Ten-Year Plan of Development and Welfare for Nigeria 1946. Sessional Paper No. 24 of 1945. Lagos: Government printer, 1946. 
Nigeria. Federal Ministry of Economic Development. First National Development Plan, 1962-1968. Lagos: Federal Government Printer, 1962.

Nigeria. Ministry of Information. Second National Development Plan, 1970-74. Lagos: Federal Government Printer, 1970.

Nigeria. Building the New Nigeria: National Development Plan, 1970-74. Nigerian National Press, Apapa.

Nigeria. Guidelines for the Third National Development Plan, 1975-80. Lagos: The Government Printer, 1973.

Nigeria. Ministry of Economic Development. Third National Development Plan, 19751980 (2 vols.) Lagos: Federal Government Printer, 1975.

\section{GREAT BRITAIN}

Report and Proceedings of the Conference of Colonial Directors of Agriculture. Colonial no. 156. London: HMSO, 1938.

Overseas Resource Development Act. London: HMSO, 1948.

Colonial Development Corporation. London: HMSO, 1948.

\section{Books}

Ayida, A. A. \& Onitiri, H. M. A. (ed.). Reconstruction and Development in Nigeria: Proceedings of a National Conference. Ibadan: Oxford University Press, 1971.

Azikiwe, Nnamdi. My Odyssey: An Autobiography. London: Hurst, 1970.

Bello, Ahamadu. My Life: An Autobiography. London, 1962. 
Gray, Clive S. (ed.) Inside Independent Nigeria: Diaries of Wolfgang Stolper, 1960-1962. Burlington, VT: Ashgate Publishing Company, 2003.

Stolper, Wolfgang. Planning Without Facts: Lessons in Resource Allocation from Nigeria's Development. Cambridge, MA: Harvard University Press, 1966.

\section{Secondary Sources}

\section{UNPUBLISHED PAPERS AND DISSERTATIONS}

Belmonte, Monica L. "Reining in Revolution: The US Response to British Decolonization in Nigeria in an Era of Civil Rights, 1953-1960." PhD dissertation, Georgetown University, 2003.

Berry, Sara, "Cocoa in Western Nigeria, 1890-1940: A Study of Innovation in a Developing Country." PhD dissertation, University of Michigan, 1967.

Hodge, Joseph Morgan. "Historicizing Development: From Intellectual Impasse to New Field of Critical Research.” West Virginia University, Morgantown.

Ibezim, Chukwumerije. The New Frontier and Africa, 1961-1963. PhD dissertation, State University of New York at Stony Brook, 1976.

Johnson, Glenn L. "Factor Markets and the Problem of Economic Development." Unpublished paper, 1966.

Ojowu, Jeremiah Ode. "Technological Transformation in Nigerian Agriculture: An Analysis of the Nigerian Agricultural Development Policies, including the Role of the Marketing Boards." PhD dissertation, the University of Connecticut, 1980. 
Sackley, Nicole. "Passage to Modernity: American Social Scientists, India, and the Pursuit of Development, 1945-1961.” PhD dissertation, Princeton University, 2004.

Young, Alden. "Accounting for Decolonization: The Origins of the Sudanese Economy, 1945-1964.” PhD dissertation, Princeton University, 2013.

Books

Aboyade, Ojetunji. Foundations of an African Economy: A Study of Investment and Growth in Nigeria. New York: Praeger, 1966.

Anderson, David. Eroding the Commons: The Politics of Ecology in Baringo, Kenya 1890-1963. Oxford: James Currey, 2002.

Anderson, David, and Richard Grove, eds. Conservation in Africa: People, Policies and Practice. Cambridge: Cambridge University Press, 1987.

Arnold, M.H. ed. Agricultural Research for Development: The Namulonge Contribution. Cambridge: Cambridge University Press, 1976.

Ashton, S. R. and S. E. Stockwell, ed. Imperial Policy and Colonial Practice, 1925-1945. London: HMSO, 1996.

Ate, Bassey E. Decolonization and Dependence: The Development of Nigeria - U.S. Relations, 1960-1984. Boulder, CO: Westview Press, 1984.

Awa, Eme O. Federal Government in Nigeria. Berkeley: University of California Press, 1964. 
Ayo, Edward Jide. Development Planning in Nigeria. Ibadan: University Press Limited, 1988.

Baldwin, K. D. S. The Niger Agricultural Project: An Experiment in African Development. Cambridge, MA: Harvard University Press, 1957.

Barbour, K. M. ed.. Planning For Nigeria: A Geographical Approach. Ibadan: University Press, 1972.

Bardhan, Pranab, ed. The Economic Theory of Agrarian Institutions. Oxford: Clarendon Press, 1989.

Barnett, Tony. The Gezira Scheme: An Illusion of Development. London: Frank Cass, 1977.

Bates, Robert H. Beyond the Miracle of the Market: The Political Economy of Agrarian Development in Kenya. Cambridge: Cambridge University Press, 1989.

Bauman, Zygmunt. Wasted Lives: Modernity and its Outcasts. Oxford: Oxford University Press, 2003.

Berman, Edward H. The Influence of the Carnegie, Ford, and Rockefeller Foundations on American Foreign Policy: The Ideology of Philanthropy. New York: State University of New York Press, 1984.

Beusekom, Monica M. van. Negotiating Development: African Farmers and Colonial Experts at the Office du Niger, 1920-1960. Oxford: James Currey, 2002.

Blackmer, Donald L. M. The MIT Center for International Studies: The Founding Years, 1951-1969. Cambridge, MA: MIT Press, 2002.

Brockway, Lucile H. Science and Colonial Expansion: The Role of the British Royal Botanic Gardens. London: Academic Press, 1979. 
Brown, Lester R. Seeds of Change. The Green Revolution and Development in the 1970s. New York: Praeger, 1970.

Buhler William, Morse Stephen, Arthur Eddie, et.al., Science, Agriculture and Research: A Compromised Participation? London: Earthscan Publications, 2002.

Butler, L. J. Industrialisation and the British Colonial State: West Africa, 1939-1951. London: Frank Cass, 1997.

Campbell, Bonnie K. \& John Loxley, ed. Structural Adjustment in Africa. New York: St. Martin's Press, 1989.

Chambers, Robert. Rural Development: Putting the Last First. New York: Longman, 1983.

Clayton, Eric. Agrarian Development in Peasant Economies: Lessons from Kenya. New York: Macmillan, 1964.

Cohen, Robin. Labour and Politics in Nigeria. London: Heinemann, 1974.

Collins, Paul, ed. Administration for Development in Nigeria: Introduction and Readings. Lagos, Nigeria: African Education Press, 1980.

Constantine, Stephen. The Making of British Colonial Development Policy, 1914-1940. London: Frank Cass, 1984.

Cooper, Frederick. Africa Since 1940: The Past of the Present. Cambridge: Cambridge University Press, 2002. . Decolonization and African Society: The Labor Question in French and British Africa. Cambridge: Cambridge University Press, 1996. 
Cooper, Frederick and Ranadall Packard, eds. International Development and the Social Sciences: Essays on the History and Politics of Knowledge. Berkeley: University of California Press, 1997.

Cowen, M.P. and R. N. Shenton. Doctrines of Development. New York: Routledge, 1996.

Crowder, Michael. The Story of Nigeria. London: Faber \& Faber, 1962.

Crush, Jonathan, ed. Power of Development. Routledge, 1995.

Dale, H.E. Daniel Hall: Pioneer in Scientific Agriculture. London: John Murray, 1956.

de Wilde, John C., ed. Experiences with Agricultural Development in Tropical Africa. 2 vols. Baltimore: John Hopkins University Press, 1967.

Dean, Edwin. Plan Implementation in Nigeria: 1962-1966. Ibadan, Nigeria: Oxford University Press, 1972.

Dibua, Jeremiah I. Development and Diffusionism: Looking Beyond Neopatrimonialism in Nigeria, 1962-1985. Palmgrave Macmillan, 2013.

. Modernization and the Crisis of Development in Africa: The Nigerian Experience. Brookfield, VT: Ashgate, 2006.

Duignan, Peter and L. H. Gann. The United States and Africa: A History. Cambridge: Cambridge University Press, 1984.

Eicher, Carl K. and Carl Liedholm, eds. Growth and Development of the Nigerian Economy. East Lansing: Michigan State University, 1970.

Ekbladh, David. Great American Mission: Modernization and the Construction of an American World Order. Princeton, NJ: Princeton University Press, 2010.

Ekundare, Olufemi R. An Economic History of Nigeria, 1860-1960. New York: Africana Publishing Co., 1973. 
Eleazu, Uma O. Nigeria: The First 25 Years. Ibadan: Heinemann, 1985.

Engerman, David C., Nils Gilman, Mark H. Harefele, and Michael E. Latham (eds.), Staging Growth: Modernization, Development and the Global Cold War. Amherst: University of Massachusetts Press, 2003.

Escobar, Arturo. Encountering Development: The Making and Unmaking of the Third World. Princeton, NJ: Princeton University Press, 1995.

Ezera, Kalu. Constitutional Developments in Nigeria: An Analytical Study of Nigeria's Constitution-Making Developments and the Historical and Political Factors that affected Constitutional Change. Cambridge: Cambridge University Press, 1960.

Falola, Toyin. Development Planning and Decolonization in Nigeria. Gainesville, FL: University of Florida Press, 1996. . The History of Nigeria. Westport: Greenwood Press, 1999. . Culture and Customs of Nigeria. Westport: Greenwood Press, 2001. . Economic Reforms and Modernization in Nigeria, 1945-1965. Kent, OH: Kent State University Press, 2004.

Falola, Toyin \& Mathew M. Heaton. A History of Nigeria. Cambridge: Cambridge University Press, 2008.

Faulkner, O.T., and J. R. Mackie. West African Agriculture. Cambridge: Cambridge University Press, 1933.

Ferguson, James. Expectations of Modernity: Myths and Meanings of Urban Life on the Zambian Copperbelt. Berkeley: University of California Press, 1999.

Forrest, Thomas. Politics, Policy, and Capitalist Development in Nigeria, 1970-1990. Boulder, CO: Westview Press, 1992. 
Freedman, Jim, ed. Transforming Development: Foreign Aid for a Changing World. Toronto: University of Toronto Press, 2000.

Gailey, Harry A. The Road to ABA: A Study of British Administrative Policy in Eastern Nigeria. New York: New York University Press, 1970.

Ghai, Dharan, and Samir Radwan, eds. Agrarian Policies and Rural Poverty in Africa. Geneva: International Labour Organisation, 1983.

Gilman Nils. Mandarins of the Future: Modernization Theory in Cold War America. Baltimore, MD: John Hopkins University Press, 2003.

Grubbs, Larry. Secular Missionaries: Americans and African Development in the 1960s. Amherst: University of Massachusetts Press, 2009.

Gupta, Kulwant Rai. Economics of Development and Planning History, Principles, Problems and Policies. New Delhi: Atlantic, 2009.

Havinden, Michael \& David Meredith. Colonialism and Development: Britain and its Tropical Colonies, 1850-1960. London: Routledge, 1993.

Helleiner, Gerald K. Peasant Agriculture, Government, and Economic Growth in Nigeria. Homewood, IL: R.D. Irwin, 1966.

Heyer, Judith; Roberts Pepe and Gavin Williams, eds. Rural Development in Tropical Africa. London: MacMillan, 1981.

Hodder, B. W. Economic Development in the Tropics. London: Methuen, 1968.

Hodge, Joseph M. Triumph of the Expert: Agrarian Doctrines of Development and the Legacies of British Colonialism. Athens, OH: Ohio University Press, 2007.

Hopkins, Anthony G. An Economic History of West Africa. London: Longman, 1973. 
Huth, W. P. Traditional Institutions and Land Tenure as Related to Agricultural Development among the Ibo of Eastern Nigeria. Madison, WI: Land Tenure Center, 1969.

Kent, John. British Imperial Strategy and the Origins of the Cold War, 1944-49. Leicester: Leicester University Press, 1993.

Konadu-Agyemang, Kwadwo \& Kwamina Panford, eds. Africa's Development in the Twenty-First Century. Burlington, VT: Ashgate Publishing Company, 2006.

Kilby, Peter. Industrialization in an Open Economy: Nigeria 1945-1966. Cambridge: Cambridge University Press, 1969.

Kothari, Uma, ed. A Radical History of Development Studies: Individual Institutions and Ideologies. London: Zed Books, 2005.

Idachaba, Francis. Rural Infrastructure in Nigeria. Ibadan: Ibadan University Press, 1985.

Isaacman, Allen and Barabara Isaacman. Dams Displacement, and the Delusion of Development: Cahora Bassa and Its Legacies in Mozambique, 1967-2007. Athens: Ohio University Press, 2013.

Jones, George Howard. The Earth Goddess. A Study of Native Farming on the West African Coast. London: Longmans, Green and Co, 1936.

Lagemann, Johannes. Traditional African Farming Systems in Eastern Nigeria. Munich: Weltforum, 1977.

Latham, Michael, ed. Staging Growth: Modernization, Development, and the Global Cold War. Amherst, MA: University of Massachusetts Press, 2003. 
. The Right Kind of Revolution: Modernization, Development and U.S.

Foreign Policy from the Cold War to the Present. Ithaca: Cornell University Press, 2011.

Leach, Melissa and Mearns, Robin, eds. The Lie of the Land: Challenging Received Wisdom on the African Environment. Oxford: James Currey, 1996.

Lee, J.M. and Martin Petter. The Colonial Office, War and Development Policy: Organization and the Planning of a Metropolitan Initiative, 1939-1945. London: Maurice Temple Smiths Ltd, 1981.

Lewis, Arthur W. Reflections on Nigeria's Economic Growth. Development Center of the Organisation for Economic Co-operative and Development, 1966.

Leys, Colin. Rise and Fall of Development Theory. London: James Murray, 1996.

Mahoney, Richard D. JFK: Ordeal in Africa. New York: Oxford University Press, 1985.

Masfield, G. B. A History of the Colonial Agricultural Service. Oxford: Clarendon Press, 1972. . A Short History of Agriculture in the British Colonies. Oxford: Clarendon Press, 1950.

Maxon, Robert M. Going Their Separate Ways: Agrarian Transformation in Kenya, 1930-1950. London: Associated University Presses, 2003.

Melson, Robert \& Howard Wolpe, eds. Nigeria: Modernization and the Politics of Communalism. East Lansing: Michigan State University Press, 1971.

Milner, David. America's Rasputin: Walt Rostow and the Vietnam War. New York: Hill and Wang, 2008. 
Moon, Suzanne. Technological and Ethical Idealism. A History of Development in the Netherlands East Indies. Leiden: CNWS Publications, 2007.

Morgan, D. J. The Official History of Colonial Development: Developing British Colonial Resources, 1945-51 v.2. London: Palgrave Macmillan, 1980.

Mous, Dan. State Power, Agrarian Policies and Peasant Welfare: Politics of Agricultural Marketing and Commodity Boards in Nigeria. Bloomington: AuthorHouse, 2014.

Ninkovich, Frank. Modernity and Power: A History of Domino Theory in the Twentieth Century. Chicago: University of Chicago Press, 1994.

Nnoli, Okwudiba, ed. Path to Nigerian Development. Westport, CT: L. Hill, 1981.

Norman, David W. Farming Systems in the Nigerian Savanna: Research and Strategies for Development. Boulder, CO: Westview Press, 1982.

Nwachukwu, Levi A and G. N. Uzoigwe. Troubled Journey: Nigeria Since the Civil War. Lanham, MD: University Press of America, 2004.

Ochonu, Moses E. Colonial Meltdown: Northern Nigeria in the Great Depression. Athens: Ohio University Press.

Obot, Johnson. Environment and Development in Nigeria. Port Harcourt, Nigeria: Double Diamond Publications, 2002.

Okigbo, P.N.C. National Development Planning in Nigeria, 1900-1992. London: J. Currey, 1989.

Onimode, Bade. Imperialism and Development in Nigeria. London: Zed Press, 1982.

Osaghae, Eghosa E. Crippled Giant: Nigeria Since Independence. Bloomington: Indiana University Press, 1998. 
Paden, John N. Ahmadu Bello, Sardauna of Sokoto: Values and Leadership in Nigeria. London: Hodder and Stoughton, 1986.

Parmar, Inderjeet. Foundations of the American Century: The Ford, Carnegie, \& Rockefeller Foundations in the Rise of American Power. New York: Columbia University Press, 2012.

Paterson, Thomas G. ed. Kennedy's Quest for Victory: American Foreign Policy, 19611963. New York: Oxford University Press, 1989.

Peet, Richard. Unholy Trinity: The IMF, World Bank and WTO. New York: Zed Books, 2003.

Phillips, Anne. Enigma of Colonialism: British Policy in West Africa. Bloomington, IN: Indiana University Press, 1989.

Pierce, Steven. Farmers and the State in Colonial Kano: Land Tenure and the Legal Imagination. Bloomington: Indiana University Press, 2005.

Richards, Paul. Indigenous Agricultural Revolution: Ecology and Food Production in West Africa. London: Hutchinson, 1985.

Rivkin, Arnold. Africa and the West: Elements of Free-World Policy. New York: F.A. Praeger, 1962.

. The African Presence in World Affairs. New York: Free Press of Glencoe, 1963.

Rist, Gilbert. The History of Development: From Western Origins to Global Faith. New York: Zed Books, 2002.

Rostow, W. W. The United States in the World Arena: An Essay in Recent History. New York: Harper \& Brothers, 1960. 
. Eisenhower, Kennedy, and Foreign Aid. Austin, TX: The University of Texas

Press, 1985.

. Stages of Economic Growth. Cambridge: Cambridge University Press, 1990.

Sada, Pius. Environmental Issues and Management in Nigerian Development. Ibadan, Nigeria: Evans Brothers, 1988.

Schraeder, Peter. United States Foreign Policy Toward Africa: Incrementalism, Crisis and Change. Cambridge: Cambridge University Press, 1994.

Schuknecht, Rohland. British Colonial Development Policy after the Second World War: The Case of Sukumaland. Tanganyika. Berlin: Lit Verlag, 2010.

Scott, James C. Seeing Like a State: How Certain Schemes to Improve the Human Condition Have Failed. New Haven: Yale University Press, 1988.

Shenton, Robert. The Development of Capitalism in Northern Nigeria. London: James Currey, 1986.

Shephard, Bruce R. Nigeria, Africa, and the United States: From Kennedy to Reagan. Bloomington, IN: Indiana University Press, 1991.

Simpson, Bradley. Economists with Guns: Authoritarian Development and U.S. Indonesian Relations, 1960-1968. Stanford, CA: Stanford University Press, 2008.

Staples, Amy. The Birth of Development: How the World Bank, Food and Agriculture Organization and World Health Organization Changed the World, 1945-1965. Ohio: Kent State University Press, 2006.

Thompson, Joseph E. American Policy and African Famine: The Nigeria-Biafra War, 1966-1970. Westport, CT: Greenwood Press, 1990. 
Thurston, Anne. The Intensification of Smallholder Agriculture in Kenya: The Genesis and Implementation of the Swynnerton Plan. Oxford Development Records Project, Report 6. Oxford: Rhodes House Library, 1984.

Tiffen, Mary, et.al. More People, Less Erosion: Environmental Recovery in Kenya. Nairobi: Acts Press, 1994.

Tignor, Robert L. W. Arthur Lewis and the Birth of Development Economics. Princeton: Princeton University Press, 2006.

Tilley, Helen. Africa as a Living Laboratory: Empire, Development, and the Problem of Scientific Knowledge, 1870-1950. Chicago: The University of Chicago Press, 2011.

Toyden, S. ed. Constitutionalism and National Development in Nigeria: Proceedings of the $17^{\text {th }}$ Annual Conference of the Nigerian Political Science Association held at the University of Jos, 21-23 November 1990. Ibadan: Nigerian Political Science Association, 1990.

Ugbong, Innocent, Mbia S. Mbia and Leonard E. Omang, eds. An Inter-disciplinary Approach to Issues and Problems of National Development. Calabar, Nigeria: Index Educational Foundation Publishers, 1999.

Vreeland, James Raymond. The IMF and Economic Development. Cambridge: Cambridge University Press, 2003.

Watts, Michael. Silent Violence: Food, Famine, and Peasantry in Northern Nigeria. Berkeley: University of California Press, 1983. . ed. State, Oil, and Agriculture in Nigeria. Berkeley: University of California Press, 1987. 
Westad, Odd Arne. The Global Cold War: Third World Interventions and the Making of our Times. Cambridge: Cambridge University Press, 2007.

\section{Articles, Chapters}

Adams, William M. "Large Scale Irrigation in Northern Nigeria: Performance and Ideology." Royal Geographical Society 16, 3(1991): 287-300.

Austin, Gareth. "African Economic Development and Colonial Legacies." Revue Internationale de politique de developpement 1 (2010): 11-32.

Bamba, Abou B. “Triangulating a Modernization Experiment: The United States, France, and the Making of the Kossou Dam in Central Ivory Coast." Journal of Modern European History 8, 1 (2010): 66-84.

Berry, Sara S. "The Concept of Innovation and the History of Cocoa Farming in Western Nigeria." The Journal of African History 15, 1 (1974)): 83-95.

Biggs, David. "Breaking from the Colonial Mold: Water Engineering and the Failure of Nation-Building in the Plain of Reeds, Vietnam." Technology and Culture 49, 3 (2008): 599-623.

Bonneuil, Christophe. "Development as Experiment: Science and State Building in Late Colonial and Postcolonial Africa, 1930-1970.” Osiris 15 (2000): 258-281.

Bowman, Andrew. "Mass Production or Production by the Masses? Tractors, Cooperatives, and the Politics of Rural Development in Post-Independence Zambia." Journal of African History 52, 2 (2011): 201-221. 
Cowen, Mike. "Early Years of the Colonial Development Corporation: British State Enterprise Overseas during Late Colonialism." The Royal African Society, 83, 330 (1984): 63-75.

Cullather, Nick. "Development? It's History.” Diplomatic History 24, 4 (2000), 641-653. . "Miracles of Modernization: The Green Revolution and the Apotheosis of Technology." Diplomatic History 28, 2 (2004): 227-254.

Eicher, Carl K. "The Dynamics of Long-Term Agricultural Development in Nigeria." Journal of Farm Economics 49, 5 (December, 1967): 1158-1170.

Ehrensaft, Philip. "The Political Economy of Informal Empire in Pre-Colonial Nigeria, 1807-1884.” Canadian Journal of African Studies 6,3 (1972): 451-490.

Grubbs, Larry. “Bringing 'The Gospel of Modernization' to Nigeria: American Nation Builders and Development Planning in the 1960s." Peace \& Change 31, 3 (2006): 279-308.

Hume, Nutcombe H. "The Work of the Colonial Development Corporation." Journal of the Royal Society of Arts 104, 4984 (1956): 775-791.

Hyden, Goran. "The Reslience of the Peasant Mode of Production: The Case of Tanzania.” In Agricultural Development in Africa: Issues of Public Policy. Edited by Robert Bates and Michael Lofchie. New York: Praeger, 1980.

Ijere, M.O. "Colonial Policy in Nigerian Agriculture and its Implementation." Agricultural History 48, 2 (April, 1974): 298-304.

Iwuagwu, O. "Colonial and Post-Independence Agricultural Policies in Eastern Nigeria, 1946-1980." Lagos Historical Review 8 (2008): 64-78. 
Lubeck, Paul M. "The Crisis of African Development: Conflicting Interpretations and Resolutions.” Annual Review of Sociology 18 (1992): 519-540.

Nwosu, Humphrey N., "Nigeria's Third National Development Plan, 1975-80: Major Problems to Implementation.” Africa Today 24, 4 (1977): 23-38.

Ojiaku, Mazi Okoro \& Gene Ulansky. "Early Nigerian Response to American Education." Phylon 33, 4, (1972): 380-388.

Stolper, Wolfgang. "Problems of Development Planning." In Leading Issues in Economic Development. Edited by Gerald M. Meier. New York: Oxford University Press, 1976.

. "Social Factors in Economic Planning with Special Reference to Nigeria", in, Carl K. Eicher and Carl Liedholm, eds. Growth and Development of the Nigerian Economy. East Lansing: Michigan State University, 1970.

United Nations. Center for Development Planning, Projections, and Policies. "Implementation of Development Plans: The Experience of Developing Countries in the First Half of the 1970s." Journal of Development Planning 12, (1977): 1-69.

Walker, Ezekiel Ayodele. "Structural Change, the Oil Boom and the Cocoa Economy of Southwestern Nigeria, 1973-1980s.” The Journal of Modern African Studies 38, 1 (2000): 71-87.

Wallace, Tina. "The Challenge of Food: Nigeria's Approach to Agriculture 1975-80." Canadian Journal of African Studies 15, 2 (1981): 239-258.

White, Nicholas J. "Reconstructing Europe through Rejuvenating Empire: the British, French, and Dutch Experiences Compared." Past and Present 6 (2011): 211-236. 
Wicker, E. R. "The Colonial Development Corporation (1948-54)." The Review of Economic Studies, 23, 3 (1956): 213-228. 